UNIVERSIDADE DE SÃO PAULO

FACULDADE DE FILOSOFIA, LETRAS E CIÊNCIAS HUMANAS

DEPARTAMENTO DE LETRAS MODERNAS

PROGRAMA DE PÓS-GRADUAÇÃO EM LÍNGUA E LITERATURA ALEMÃ

Laura da Silva Monteiro Chagas

O projeto estético de Rilke nas Anotações de Malte Laurids Brigge

(Versão corrigida)

São Paulo 
UNIVERSIDADE DE SÃO PAULO

FACULDADE DE FILOSOFIA, LETRAS E CIÊNCIAS HUMANAS

DEPARTAMENTO DE LETRAS MODERNAS

PROGRAMA DE PÓS-GRADUAÇÃO EM LÍNGUA E LITERATURA ALEMÃ

Laura da Silva Monteiro Chagas

\title{
O projeto estético de Rilke nas Anotações de Malte Laurids Brigge
}

\author{
(Versão corrigida)
}

Dissertação apresentada ao Programa de Língua e Literatura Alemã do Departamento de Letras Modernas da Faculdade de Filosofia, Letras e Ciências Humanas da Universidade de São Paulo para obtenção do título de Mestre em Letras.

Orientadora: Prof. ${ }^{\text {a }}$ Dr. ${ }^{\text {a Luciana Villas Bôas }}$

O presente trabalho foi realizado com apoio da Coordenação de Aperfeiçoamento de Pessoal de Nível Superior - Brasil (CAPES) - Código de Financiamento 001. 
Autorizo a reprodução e divulgação total ou parcial deste trabalho, por qualquer meio convencional ou eletrônico, para fins de estudo e pesquisa, desde que citada a fonte.

Catalogação na Publicação

Serviço de Biblioteca e Documentação

Faculdade de Filosofia, Letras e Ciências Humanas da Universidade de São Paulo

C426p Chagas, Laura da Silva Monteiro Laurids Brigge / Laura da Silva Monteiro Chagas ; orientadora Luciana Villas Bôas. - São Paulo, 2019. $145 \mathrm{f}$.

Dissertação (Mestrado) - Faculdade de Filosofia, Letras e Ciências Humanas da Universidade de São Paulo. Departamento de Letras Modernas. Área de concentração: Língua e Literatura Alemã.

1. Rainer Maria Rilke. 2. literatura e artes visuais. 3. romance. 4. projeto estético. 5. criação artística. I. Villas Bôas, Luciana, orient. II. Título. 


\section{ENTREGA DO EXEMPLAR CORRIGIDO DA DISSERTAÇÃO/TESE \\ Termo de Ciência e Concordância do (a) orientador (a)}

Nome do (a) aluno (a): Laura da Silva Monteiro Chagas

Data da defesa: 10/06/2019

Nome do Prof. (a) orientador (a): Luciana Villas Bôas

Nos termos da legislação vigente, declaro ESTAR CIENTE do conteúdo deste EXEMPLAR

CORRIGIDO elaborado em atenção às sugestões dos membros da comissão Julgadora na sessão de defesa do trabalho, manifestando-me plenamente favorável ao seu encaminhamento e publicação no Portal Digital de Teses da USP.

São Paulo, 22/12/2019.

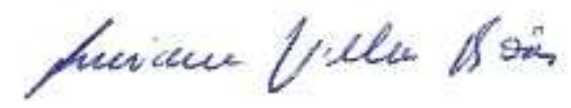


CHAGAS, Laura da Silva Monteiro. O projeto estético de Rilke nas Anotações de Malte Laurids Brigge. 2019. 145 p. Dissertação (Mestrado). Faculdade de Filosofia, Letras e Ciências Humanas. Universidade de São Paulo, 2019.

Dissertação apresentada ao Programa de Língua e Literatura Alemã do Departamento de Letras Modernas da Faculdade de Filosofia, Letras e Ciências Humanas da Universidade de São Paulo para obtenção do título de Mestre em Letras.

Orientadora: Prof. ${ }^{a}$. Dr. ${ }^{a}$ Luciana Villas Bôas

Aprovado em:

Banca Examinadora

Prof. (a) Dr. (a)

Instituição:

Julgamento:

Prof. (a) Dr. (a)

Instituição:

Julgamento:

Prof. (a) Dr. (a)

Instituição:

Julgamento: 
Para meus pais, minha irmã e Thiago 


\section{AGRADECIMENTOS}

Aos meus pais e minha irmã, pelo apoio incondicional.

À professora Luciana Villas Bôas, pela orientação, por acreditar em meu potencial, pela paciência e por sempre me mostrar como posso melhorar.

Aos professores Helmut Galle e Juliana Perez, pela ajuda preciosa, pela escuta, pela contribuição a este trabalho e à minha formação acadêmica, desde a graduação.

Ao professor Jorge de Almeida, pela importante contribuição ao meu trabalho em meu exame de qualificação.

À Fundação CAPES, pela bolsa de mestrado, sem a qual este trabalho não teria sido possível.

Aos amigos e colegas de pós-graduação, em especial Mariana Holms e Matheus Guménin Barreto, pela dedicação e disposição em propor atividades e aproximar os estudantes de pósgraduação do Programa de Língua e Literatura Alemã.

Ao meu companheiro, Thiago, por estar ao meu lado.

Às amigas e amigos: Clarisse, Letícia, Paula, Lia, Andréa, Fernanda, Júlia, Cintia, Daniel, Carol, Amanda, Bruno, Aline, Michelli, Lorena, Georgia, Carla e Maralice, pelo afeto, cuidado e compreensão, pelas trocas e parcerias. 
CHAGAS, Laura S. M. O projeto estético de Rilke nas Anotações de Malte Laurids Brigge. 2019. 145 p. Dissertação (Mestrado). Faculdade de Filosofia, Letras e Ciências Humanas. Universidade de São Paulo, 2019.

\section{RESUMO}

Entre 1904 e 1910, Rainer Maria Rilke escreveu seu único romance, Die Aufzeichnungen des Malte Laurids Brigge. No romance, o protagonista Malte Laurids Brigge, um jovem poeta estrangeiro vivendo sozinho em Paris, afirma que está aprendendo a ver, e esse novo aprendizado se desdobra em reflexões sobre a escrita e na redefinição do trabalho artístico. Esta dissertação apresenta uma leitura do romance rilkeano focada no tema do olhar e em seus desdobramentos, com o objetivo de argumentar que o protagonista desenvolve um projeto estético a partir de seu novo aprendizado. Procuramos também demonstrar que o projeto estético de Malte é semelhante ao projeto que Rilke desenvolve a partir de sua experiência com as obras de Auguste Rodin e Paul Cézanne e que deu origem aos Neue Gedichte em 1907. A fim de sustentar essa leitura do romance, analisamos o ensaio de Rilke sobre Rodin, Auguste Rodin, publicado em 1903, e uma série de cartas de 1907 em que o poeta escreve reflexões sobre as pinturas de Cézanne, Briefe über Cézanne, publicadas postumamente, em 1952. Nossa análise dos escritos estéticos de Rilke é focada principalmente no papel do olhar na criação artística, de modo a comparar como se dá a relação entre olhar e criação artística no romance e nas reflexões sobre as artes visuais.

Palavras-chave: Rainer Maria Rilke; literatura e artes visuais; romance; projeto estético; criação artística. 


\begin{abstract}
From 1904 to 1910, Rilke wrote his only novel, Die Aufzeichnungen des Malte Laurids Brigge. In the novel, the protagonist Malte Laurids Brigge - a young, foreigner poet living alone in Paris - states that he is learning to see, and this new learning process unfolds in new thoughts on writing and in the redefinition of the artistic work. This thesis presents a reading of the rilkean novel focused on the theme of looking and its unravelling, with the intention of sustaining that the protagonist develops an aesthetic project from his new learning. We also attempt to demonstrate that Malte's project is similar to the project Rilke develops from his experience with Rodin's and Cézanne's works and that originates the Neue Gedichte. In order to do that, besides the Aufzeichnungen, we analyse Rilke's essay about Rodin, Auguste Rodin, published in 1903, and the collected letters from 1907 in which he wrote about Cézanne's paintings, Briefe über Cézanne, published posthumoulsy in 1952. Our analysis of Rilke's aesthetic writings is primarily focused on the role of looking in artistic creation, aiming to compare how the act of looking is interwined with the act of writing or painting or modelling in Rilke's novel and aesthetic essays.
\end{abstract}

Keywords: Rainer Maria Rilke; literature and visual arts; novel; aesthetic project; artistic creation. 


\section{SUMÁRIO}

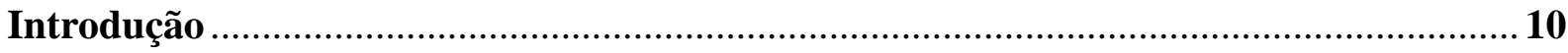

Capítulo 1. Die Aufzeichnungen des Malte Laurids Brigge ............................................ 16

1.1. Aufzeichnungen no contexto da obra de Rilke ................................................ 16

1.2. Malte como flâneur? Rilke, leitor de Baudelaire ............................................ 25

1.3. Tradição e modernidade: o legado romântico ..................................................... 28

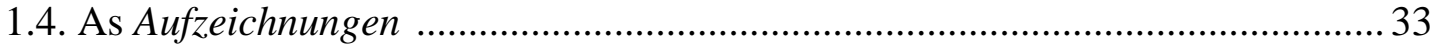

1.5. Olhar, experiência, memória e escrita …............................................................ 42

Capítulo 2. Die Aufzeichnungen e o pensamento de Rilke sobre arte ..............................62

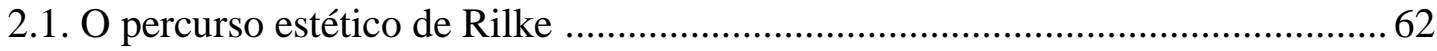

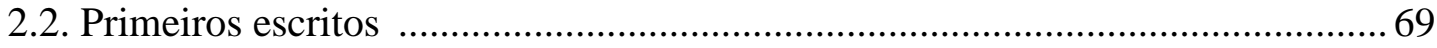

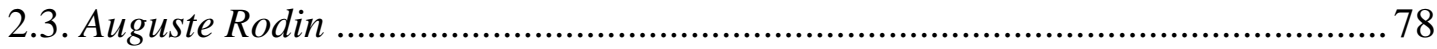

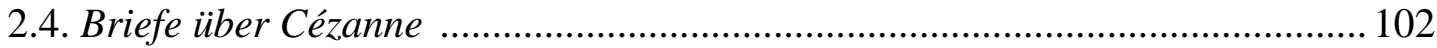

2.5. Die Aufzeichnungen des Malte Laurids Brigge como texto estético programático

Considerações finais 


\section{Introdução}

A presente dissertação surgiu de uma inquietação sobre o papel do olhar na criação artística, suscitada pela leitura do romance Die Aufzeichnungen des Malte Laurids Brigge, de Rainer Maria Rilke (1875-1926), escrito entre os anos de 1904 e 1910. Ela tem origem também no desejo de desenvolver uma pesquisa de caráter interdisciplinar que promovesse um diálogo entre os campos da literatura e das artes visuais e, tendo isso em vista, encontramos na obra de Rilke um excelente objeto de estudo. O projeto inicial da pesquisa havia recebido o título de "Die Aufzeichnungen des Malte Laurids Brigge: o gesto escultórico no romance de Rilke", e tinha como objetivo propor uma leitura do romance como uma construção de um retrato a partir de premissas estéticas que Rilke havia observado e registrado em sua monografia sobre a obra do escultor francês Auguste Rodin (1840-1917). À medida que nos aprofundamos na investigação e análise das Aufzeichnungen e da monografia Auguste Rodin, vislumbramos um viés mais rico e interessante na possibilidade de ler o romance como construção de um projeto estético. Decidimos examinar qual a relevância do tema do olhar no projeto estético de Rilke e qual a sua relação com as reflexões do escritor sobre as artes visuais na virada do século XX.

O ponto de partida de nossa investigação encontra-se nas primeiras páginas do romance, na afirmação do protagonista Malte de que ele "aprende a ver": "Ich lerne sehen."1 (RILKE, 1982, p. 10). Esse aprendizado é apontado pelo próprio personagem Malte, algumas páginas adiante, como uma nova e importante ferramenta para seu ofício de poeta, portanto o mesmo de Rilke: "Ich glaube, ich müßte anfangen, etwas zu arbeiten, jetzt, da ich sehen lerne."” (RILKE, 1982, p. 21). A ideia de que "saber ver" é um conhecimento desejável - se não necessário - para (saber) escrever, não é inédita. Ela encontra eco, por exemplo, em “A janela de esquina do meu primo" ("Des Vetters Eckfenster"), último conto de E.T.A. Hoffmann, escrito semanas antes de sua morte em 1822. "A janela de esquina" destoa consideravelmente de todo o resto da produção literária de Hoffmann. Sem nenhum elemento fantástico, maravilhoso ou estranho, o texto gira em torno da conversa entre dois primos anônimos: um escritor idoso que se vê preso em seu apartamento devido à crescente

\footnotetext{
1 "Estou aprendendo a ver." (RILKE, 1979, p. 6). A tradução das Aufzeichnungen citada neste trabalho é de Lya Luft.

2 "Acho que eu deveria começar a fazer algo, a trabalhar, agora que estou aprendendo a ver." (RILKE, 1979, p. $14)$.
} 
debilidade física, que o impedia não só de andar, mas também de escrever; e seu primo, narrador do conto, que o visita.

Melancólico por não poder exercer mais seu ofício, o primo escritor se consola com a vista da janela, "em frente à praça do mercado, rodeada por construções suntuosas, em cujo centro se ergue o colossal edifício do teatro [...]. [...] da janela de um pequeno gabinete ele abarca num lance de olhos todo o panorama da grandiosa praça.” (HOFFMANN, 2010, p. 11). O primo visitante, sem compreender de que maneiras a vista da praça pudesse promover entretenimento por muito tempo, provoca a indignação do primo escritor, que afirma que o que lhe falta é saber ver: "Primo, primo! Vejo agora que em seu íntimo não arde uma centelha sequer de talento literário. Falta-lhe a disposição mais elementar para poder seguir os passos de seu primo digno e paralítico, ou seja, um olho! Um olho que realmente enxergue!" (HOFFMANN, 2010, p. 16, grifo nosso). O velho escritor se dispõe então a ensiná-lo "as primícias da arte de enxergar" (HOFFMANN, 2010, p. 16-17) e, na sequência, os dois personagens passam a observar os transeuntes da praça, especulando quais seriam suas histórias a partir dos detalhes de suas fisionomias, vestimentas, movimentos, expressões faciais e do que pareciam buscar na feira ao ar livre.

A “arte de enxergar" de Hoffmann, que o personagem toma como parte fundamental da tarefa do escritor, é esta: observar os detalhes das pessoas, objetos e lugares que se apresentam, relacioná-los ao próprio repertório de informações, experiências e ideias sobre pessoas, objetos e lugares e, a partir dessas relações, tecer suposições a respeito do que é observado. O olhar do primo escritor hoffmanniano é inventivo, apoiado em concepções préexistentes como a da fisiognomonia, teoria que esteve em voga no final do século XVIII e início do XIX, segundo a qual seria possível avaliar o caráter ou a personalidade de uma pessoa a partir da observação de suas características físicas (cf. MAZZARI, 2010, p. 72). No entanto, a concepção de Rilke do que é "saber ver" seria ainda a mesma de Hoffmann, mais de oitenta anos após a escrita de "A janela de esquina"? Ao longo de nossa pesquisa tornou-se claro que, mesmo que as Aufzeichnungen guardem alguma relação com o pensamento do Romantismo alemão, como veremos no primeiro capítulo desta dissertação, a prática do olhar descrita no conto de Hoffmann é o exato oposto do olhar buscado por Rilke e problematizado em seu romance.

O aprendizado do olhar que Rilke designa para seu personagem Malte nas Aufzeichnungen reside no contato intenso do poeta com as artes visuais, especialmente no encontro com Rodin e com as pinturas de Cézanne em Paris entre os anos de 1902 e 1907. 
Trata-se aqui de dois artistas cujas obras instituíram novos paradigmas de representação na arte, a partir de uma nova forma de ver o mundo natural. Strathausen ressalta que: "Modernist art does not concern itself with individual objects. It does not depict this or that particular thing, but instead teaches us a novel way of seeing things in general."3 (STRATHAUSEN, 2003, p. 198); e é esse novo olhar que procuramos investigar nesta pesquisa, destacando o tema do olhar nas Aufzeichnungen e nos escritos de Rilke sobre Rodin e Cézanne - a monografia Auguste Rodin, já mencionada, e as suas Briefe über Cézanne, de 1907. Sobre o tema do olhar nas Aufzeichnungen, Ortrud Gutjahr observa que:

Der Topos des neuen Sehens, dem Rilke seinen Erzähler unterstellt, geht auf eigene Erfahrungen in der Stadt Paris einerseits und seine Begegnung mit der bildenden Kunst anderseits zurück. Jenseits biographischer Bezüge ist für Rilkes Roman literarhistorisch eine neue Kunstauffassung relevant, die er wie eine Arbeitshypothese seinem Erzähler eingeschrieben hat. ${ }^{4}$ (GUTJAHR, 1993, p. 373).

Essa colocação de Gutjahr reforça nossa hipótese de leitura sobre o aprendizado do olhar e também sobre a construção de um projeto estético nas Aufzeichnungen. Mas, em nossa análise, procuramos investigar também os desdobramentos e as implicações desse aprendizado como, por exemplo, sua relação com um ideal de trabalho que Rilke também recebe de Rodin e de Cézanne. Como veremos adiante, esse projeto estético não é apenas delineado no romance como parte do desenvolvimento do personagem, mas repercute na obra poética de Rilke, que tem uma virada estética nos livros de poemas Neue Gedichte e Der Neuen Gedichte anderer Teil, de 1907 e 1908, respectivamente.

Uma vez que tratamos aqui de um projeto estético que leva a uma transformação na poesia de Rilke e que é ficcionalizado no romance, cabe aqui uma breve consideração sobre o caráter autobiográfico das Aufzeichnungen des Malte Laurids Brigge. Conforme aponta Judith Ryan,

Several passages in Malte Laurids Brigge have near-equivalent in Rilke's correspondence, especially with Clara Rilke and Lou Andreas-Salomé, during his Paris period; some other sections are drawn from his childhood experiences, particularly his relationship with his mother. Themes such as loneliness, alienation and disgust reflect Rilke's concerns - and his psychological difficulties - during his work on Malte Laurids Brigge. The book's autobiographical character has led many readers to identify Rilke with Malte, despite Rilke's repeated warnings that his fictional protagonist was less a direct stand-in for himself than a negative alter ego. By casting the novel as a record of a fictional writer's struggle with problems of

\footnotetext{
3 “A arte moderna não se preocupa com objetos individuais. Ela não representa esta ou aquela coisa em particular, mas sim nos ensina uma nova maneira de ver as coisas em geral.” (Tradução nossa).

4 “O tópos da nova visão, que Rilke atribui a seu narrador, vem de sua própria experiência na cidade de Paris, por um lado, e de seu encontro com as artes visuais, por outro. Além das conexões biográficas, é relevante para o romance de Rilke, literária e historicamente, um novo conceito de arte, que ele inseriu como uma hipótese de trabalho para seu narrador." (Tradução nossa).
} 
reading, writing and professional development, Rilke takes the measure of what he sees as the simultaneous potential and limitations of narrative in the early years of the twentieth century. ${ }^{5}$ (RYAN, 2004, p. 42).

Apoiando-nos nessa colocação de Ryan, ressaltamos que nesta pesquisa evitamos tratar o protagonista Malte como alter ego de Rilke. Interessa-nos traçar correspondências entre autor e personagem apenas na medida em que o texto ficcional traz à tona temas que figuram nas reflexões estéticas de Rilke.

Esta pesquisa se insere no âmbito dos estudos de Germanística Interdisciplinar, em particular no conjunto de trabalhos afins desenvolvidos por pesquisadores brasileiros nas últimas duas décadas. Ressaltamos aqui a tese de doutorado de Alexandre Rodrigues da Costa, "A transfiguração do olhar: um estudo das relações entre literatura e artes plásticas em Rainer Maria Rilke e Clarice Lispector”, desenvolvida junto à Universidade Federal de Minas Gerais e concluída em 2005; e o livro de Rita Rios, Poemas e pedras: a relação entre a escultura e a poesia partindo de Rodin e Rilke, fruto de uma pesquisa de pós-doutorado feita junto à Universidade Estadual de Campinas e publicado em 2011. Uma vez que ambas as investigações se debruçam sobre os livros e poemas para investigar a relação com as artes visuais, acreditamos que a contribuição da nossa pesquisa está no fato de trazer para a discussão uma das obras ficcionais em prosa do autor. Além das pesquisas mencionadas, encontramos outros dois estudos recentes sobre as Aufzeichnungen, desenvolvidos a partir de outras perspectivas: a dissertação de mestrado de Mércia Elena de Souza Costa, "Weltinnenraum e a teoria da relevância: a semelhança interpretativa na tradução dos Cadernos de Malte Laurids Brigge", feita junto à Universidade Federal de Minas Gerais e concluída em 2000, teve como objetivo analisar aspectos da tradução de Lya Luft das Aufzeichnungen; e a dissertação de mestrado de Renata de Freitas Martins, "A experiência do estranho no romance Die Aufzeichnungen des Malte Laurids Brigge, de Rainer Maria Rilke”, desenvolvida também pelo Programa de Língua e Literatura Alemã do Departamento de Letras Modernas na Universidade de São Paulo, concluída em 2011.

\footnotetext{
5 “Diversas passagens em Malte Laurids Brigge possuem equivalentes próximos na correspondência de Rilke, especialmente com Clara Rilke e Lou Andreas-Salomé, durante sua fase parisiense; algumas outras seções foram retiradas de experiências de sua infância, em particular sua relação com a mãe. Temas como solidão, alienação e aversão refletem preocupações de Rilke - e suas dificuldades psicológicas - durante seu trabalho em Malte Laurids Brigge. O caráter autobiográfico do livro levou muitos leitores a identificarem Rilke com Malte, apesar dos repetidos avisos de Rilke de que seu protagonista fictício era menos um substituto direto de si mesmo do que um alter ego negativo. Ao organizar o romance como o registro das dificuldades que um escritor fictício tem com leitura, escrita e desenvolvimento profissional, Rilke toma a medida do que ele vê simultaneamente como potencial e limitações da narrativa no início do século vinte.” (Tradução nossa).
} 
É importante ressaltar ainda que o leitor brasileiro encontra à disposição uma considerável oferta de traduções e estudos introdutórios. Existem quatro traduções do romance Die Aufzeichnungen des Malte Laurids Brigge para a língua portuguesa: a primeira, de Paulo Quintela, teve sua primeira edição lançada pelo Instituto Alemão da Universidade de Coimbra em 1955, intitulada Os cadernos de Malte Laurids Brigge, com prefácio do tradutor sobre a experiência de traduzir o texto de Rilke para o português e um apêndice com a tradução de uma carta que Rilke escreveu a Witold Hulewicz, datada de 10 de novembro de 1925, com respostas às perguntas do tradutor polonês sobre as Aufzeichnungen. A editora portuguesa Relógio D’Água publicou em 2003 uma tradução das Aufzeichnungen feita por Maria Teresa Dias Furtado, intitulada As anotações de Malte Laurids Brigge, acrescida de prefácio, que contém uma análise introdutória sobre os principais temas do romance, além de notas da tradutora e inclui, ao final do livro, a mesma carta de Rilke a Hulewicz. Esta edição é especialmente interessante tanto para quem pesquisa o romance quanto para o leitor leigo porque nela foi feita a opção de numerar as anotações que compõem o romance e incluir um índice com a numeração e as primeiras palavras de cada anotação, dois recursos que facilitam a navegação por um livro difícil que demanda mais de uma leitura.

No Brasil, existe a tradução de Lya Luft de 1979, publicada inicialmente pela editora Nova Fronteira, e mais recentemente, a tradução de Renato Zwick, publicada pela editora L\&PM em 2009. Ambos os tradutores optaram por verter o título do romance para Os cadernos de Malte Laurids Brigge. Tanto a tradução de Luft quanto a de Zwick não foram prefaciadas, mas a edição da L\&PM contém notas do tradutor que auxiliam o leitor a acompanhar as diversas referências que o autor faz dentro do texto. Quanto aos textos estéticos, que aqui estudamos, existem duas edições diferentes que compilam os ensaios de Rilke sobre Rodin em língua portuguesa: a primeira é de Daniela Dantas e foi publicada em 1995 pela editora Relume Dumará. A segunda, que tem tradução de Marion Fleisher e uma breve apresentação assinada por Flávio Quintiliano, foi publicada em 2003, pela editora Nova Alexandria. Marion Fleisher também traduziu e prefaciou O Diário de Florença, publicado pela editora Nova Alexandria em 2002. Há ainda uma edição das Cartas sobre Cézanne traduzida e prefaciada por Pedro Süssekind e publicada pela editora 7 Letras em 2006. Em 2011 a editora Estação Liberdade publicou uma coletânea de contos, ensaios, cartas e resenhas de Rilke que foi organizada, prefaciada e traduzida por Claudia Cavalcanti. Os ensaios estéticos selecionados por Cavalcanti para fazer parte da coletânea são "A melodia 
das coisas" ("Notizen zur Melodie der Dinge", de 1898), "Sobre arte" ("Über Kunst", de 1898) e "Obras de arte" ("Kunstwerke", de 1903).

Quanto aos poemas da virada estética de Rilke, não existe uma tradução brasileira na íntegra de ambos os livros, Neue Gedichte e Der Neuen Gedichte anderer Teil. Destacamos aqui os nomes de Geir Campos, Augusto de Campos e José Paulo Paes como tradutores que se dedicaram a escrever versões de alguns dos poemas desses livros em coletâneas prefaciadas pelos próprios tradutores: Geir Campos divide a coletânea Poemas e Cartas a um Jovem Poeta, das edições Estrêla de Ouro (1967), com Fernando Jorge, que traduziu e prefaciou as cartas; a coletânea Rilke: Poesia-Coisa, de 1994, organizada por Augusto de Campos foi revista e ampliada pelo próprio tradutor por duas vezes e tornou-se o volume Coisas e Anjos de Rilke, publicado pela editora Perspectiva, sendo que a última edição, que possui maior número de poemas, é de 2015; e há a coletânea com traduções e um estudo introdutório de José Paulo Paes, publicada pela editora Companhia das Letras em 2012, intitulada apenas Poemas.

Por fim, cabe aqui uma última observação sobre a escolha do título da dissertação. Optamos por traduzir o termo "Aufzeichnungen" por "anotações" e não "cadernos". Após fazer uma pequena análise do título e da estrutura do romance no primeiro capítulo desta pesquisa, chegamos à conclusão de que o termo em português que melhor se adequa à concepção de "Aufzeichnungen" empregada por Rilke é "anotações", pois ele não carrega uma ideia de linearidade que o termo "cadernos" corre o risco de impor. 


\section{Die Aufzeichnungen des Malte Laurids Brigge}

\subsection{Aufzeichnungen no contexto da obra de Rilke}

Único romance de autoria de Rainer Maria Rilke (1875-1926), Die Aufzeichnungen des Malte Laurids Brigge foi composto entre fevereiro de 1904 e janeiro de 1910. Publicado em Leipzig pela Insel Verlag em 1910, o livro foi mal recebido pela crítica da época e permaneceu durante décadas à sombra da obra poética madura de Rilke (cf. FÜLLEBORN, 2000, p. 322). Entretanto, a escrita das Aufzeichnungen coincide com o período em que houve uma virada estética na obra do autor, que está intimamente relacionada às suas reflexões acerca das artes visuais, particularmente da escultura de Rodin e da pintura de Cézanne. A redação do romance teve início dois anos após a primeira ida de Rilke para a capital francesa em 28 de agosto de 1902, para onde viajara com a incumbência de escrever uma monografia sobre o já célebre escultor Auguste Rodin (1840-1917). A monografia, escrita entre novembro e dezembro daquele mesmo ano, foi publicada em Berlin por Julius Bard em 1903. Em 1902, aos 27 anos, Rilke já havia publicado contos, peças e livros de poemas. Em 1907, publicou seus Neue Gedichte em Leipzig pela Insel Verlag e, em 1908, a sequência Neue Gedichte der andere Teil foi lançada pela mesma editora. Com esses dois livros de poemas, sua trajetória poética tomava uma nova guinada. Também em 1907, Rilke frequentou o Salon d'Automne, em Paris, no qual visitou repetidas vezes uma exposição de pinturas de Paul Cézanne (18391906). O trabalho do pintor francês lhe causou fortes impressões, relatadas nas cartas enviadas à sua esposa Clara Rilke-Westhoff (1878-1954) entre junho e novembro daquele mesmo ano. Anos mais tarde, Clara selecionou algumas das cartas, que foram publicadas em $1952 \mathrm{em}$ Wiesbaden pela Insel Verlag com o título de Briefe über Cézanne.

Há certo consenso entre os críticos ${ }^{6}$ de que o encontro com Rodin - e, talvez em menor proporção, com as pinturas de Cézanne - foi determinante para a mudança que se opera na lírica de Rilke em diversos aspectos. É com ambos artistas franceses, por exemplo, que Rilke incorpora o ethos do artista dedicado inteiramente ao trabalho, expressado na máxima "toujours travailler", e o olhar objetivo como modo de trabalho. Alguns críticos investigam também como Rilke se apropria do método de Rodin em criar volume a partir da

\footnotetext{
${ }^{6}$ Por exemplo, Ortrud Gutjahr, Volker Dürr, Michaela Kopp, Carsten Strathausen, Rita Rios, Claire van den Broek e Manfred Koch.

7 “trabalhar todos os dias" (Tradução nossa).
} 
interação de superfícies e de como Cézanne cria materialidade a partir da cor para tentar criar a ilusão de materialidade em seus poemas. Essas experiências parisienses desencadeiam um processo de reflexão que leva a uma reformulação da poética de Rilke, mas é preciso lembrar que o poeta esteve desde muito cedo em contato com artistas plásticos. Assim, faz-se necessário refletir sobre a natureza e a dimensão do impacto causado em Rilke pela obra de Rodin e pela pintura de Cézanne. A escrita das Aufzeichnungen aconteceu justamente durante esse período em que Rilke reformulava suas premissas estéticas à luz das reflexões suscitadas pela experiência do encontro com Rodin e com a pintura de Cézanne. Essas premissas foram levadas a cabo na escrita dos poemas publicados em 1907 e 1908, e são descritas nas Aufzeichnungen, constituindo o que chamaremos aqui de projeto estético de Malte.

A importância que o romance Die Aufzeichnungen des Malte Laurids Brigge tem como parte desse processo de virada estética na obra rilkeana foi reconhecida por vários estudiosos, mas ainda está longe de ter sido esgotada. Apesar de não desmerecer a inovação poética de Neue Gedichte, Dorothea Lauterbach afirma que foi com as Aufzeichnungen que Rilke deu a sua maior contribuição à modernidade literária (cf. LAUTERBACH, 2013, p. 318), ainda que o reconhecimento do caráter inovador do romance só tenha acontecido muitos anos depois de sua publicação e da morte de seu autor. Ulrich Fülleborn aponta que o romance de Rilke foi recebido pela crítica da época como um texto mórbido, de caráter neorromântico e imbuído de um sentimento de mundo decadentista. Anos mais tarde, com a compreensão de que os temas tratados nas Aufzeichnungen estavam intimamente associados àqueles elaborados por Rilke em sua obra poética posterior, o romance passaria a ser considerado como uma obra negativa que se opunha a suas obras tidas como positivas, ou seja, Sonette an Orpheus e Duineser Elegien. Desse modo, enquanto a lírica rilkeana foi amplamente estudada, o romance Die Aufzeichnungen permaneceu à sua sombra durante décadas. Segundo Fülleborn, "Das beweist, daß wir Rilkes Prosabuch anders verstehen und besser zu würdigen wissen, seit wir Joyce, Kafka und Musil lesen gelernt haben."8 (FÜLLEBORN, 2000, p. 323), ou seja: apenas cinquenta anos após sua publicação foi possível reconhecer a importância de Aufzeichnungen e lê-lo como o que de fato é: um texto moderno. O estudioso argumenta que, ao contrário de Joyce, Kafka e Musil - autores de obras modernas cujo caráter inovador foi rapidamente reconhecido pela crítica - , Rilke não escreve um texto moderno a partir de uma premissa negativa, a de destruir a forma romanesca para

\footnotetext{
8 "Isso mostra que entendemos de maneira diferente e apreciamos melhor o livro em prosa de Rilke desde que aprendemos a ler Joyce, Kafka e Musil.” (Tradução nossa).
} 
reconstruí-la e transformá-la. Em vez disso, Rilke permite que aflore em seu texto a sua condição pessoal, no momento histórico em que vivia, como se fosse o ponto zero de seu trabalho. Fülleborn afirma ainda que Rilke não possuía talento para a narrativa épica, mas que, paradoxalmente, devido ao fato de ele adotar um "comportamento lírico-existencial em relação à verdade e à linguagem” (“[...] lyrisch-existentiellen Verhalten zu Wirklichkeit und Sprache [...]."), o resultado da experiência romanesca de Rilke é uma narrativa inovadora (cf. FÜLLEBORN, 2000, p. 329, tradução nossa).

Lauterbach chega mesmo a reconhecer o livro como o primeiro romance genuinamente moderno em língua alemã devido à técnica narrativa utilizada por Rilke (cf. LAUTERBACH, 2013, p. 318-319). Quando se tem em vista a forma arrojada do romance e o fato de que problematiza temas relacionados à Modernidade, é surpreendente que tanto tempo tenha se passado até que a sua natureza inovadora fosse reconhecida pela crítica. As Aufzeichnungen trazem ainda em seu cerne o desenvolvimento de um pensamento sobre a criação artística que se alinha ao projeto estético concebido por Rilke a partir das observações que fez das atividades e obras de Rodin e Cézanne, durante um momento determinante em sua formação. Procurando trazer os aprendizados recebidos dos artistas franceses para seu próprio trabalho, Rilke parece elaborar na escrita do romance as maneiras pelas quais o pensamento plástico desses dois artistas poderia ser aplicado à atividade poética e literária. Nesse sentido, as Aufzeichnungen adquirem um caráter programático, pois nelas o protagonista Malte, um poeta vivendo em Paris, entremeia suas experiências com reflexões para formular os princípios e modelos de criação artística que irá seguir em sua prática de escrita. Este capítulo busca examinar como o personagem Malte delineia seu projeto estético nas Aufzeichnungen, investigando qual é a tarefa artística que ele impõe a si mesmo, por qual caminho ele chega a formulá-la e quais são os elementos por ele considerados essenciais para desempenhá-la.

Em uma das cartas de 1907 sobre Cézanne, Rilke comenta, a propósito de uma determinada passagem das Aufzeichnungen, na qual o protagonista alude a um poema de Baudelaire $^{9}$, que o destino de Malte é o fracasso diante de suas descobertas a respeito do trabalho artístico ${ }^{10}$. Talvez influenciados pelos comentários feitos pelo próprio Rilke em sua

\footnotetext{
${ }^{9}$ A carta e a passagem mencionadas serão analisadas mais detidamente adiante nesta dissertação.

10 "Und mit einem Mal (zum ersten) begreife ich das Schicksal des Maltes Laurids. Ist es nicht das, daß diese Prüfung ihn überstieg, daß er sie am Wirklichen nicht bestand, obwohl er in der Idee von ihrer Notwendigkeit überzeugt war, so sehr, daß er sie so lange instinktiv aufsuche, bis sie sich an ihn hängte uns ihn nicht mehr verließ? Das Buch von Malte Laurids, wenn es einmal geschrieben sein wird, wird nichts als das Buch dieser Einsicht sein, erwiesen an einem, für den sie ungeheuer war.” (RILKE, 1952, p. 38). [“E de uma vez (a primeira) compreendo o destino de Malte Laurids. Não será o de alguém a quem esta provação excedia, alguém
} 
correspondência, diversos críticos entenderam as Aufzeichnungen como a narrativa do processo de destruição ou dissolução total de Malte. É o caso, por exemplo, de Andreina Lavagetto e de Maurice Blanchot. O autor francês escreveu em 1955 um ensaio a respeito do tema da morte na obra de Rilke, tratando extensamente do romance Aufzeichnungen. Nesse ensaio, a morte serve como ponto de partida para uma problematização de questões inerentes à Modernidade. Para Blanchot, o tema da morte anônima e impessoal nas grandes cidades modernas, tratado pelo narrador Malte nas primeiras páginas do romance, influencia a tarefa artística do poeta. Lido por esse viés, o romance contrastaria a vida e a morte na cidade grande e nas antigas sociedades rurais. Nele se oporiam a Dinamarca natal de Malte, onde as pessoas morriam uma morte própria, trazida consigo durante toda a vida, e a Paris moderna, onde se corre o risco constante de viver e morrer apartado de si mesmo. A revelação da experiência moderna da morte seria determinante para as percepções de Malte sobre o fazer artístico.

A fortuna crítica das Aufzeichnungen ensina que o romance tematiza a Modernidade em seus diferentes aspectos. Enquanto Blanchot investiga a morte impessoal, Frederick Garber analisa a ruptura entre passado e presente percebida por Malte na cidade grande. $\mathrm{O}$ crítico argumenta que as observações cuidadosamente detalhadas de Malte revelam uma tentativa de criar ordem a partir dos estímulos que recebe do ambiente estranho e caótico no qual se encontra, e o meio para isso seria uma nova maneira de ver, recém-aprendida. Tal empreendimento seria análogo à tarefa do artista que precisa organizar a matéria a partir da qual forjará seu trabalho, matéria que, no caso de Malte, não é entendida completamente pelo poeta. De acordo com a análise de Garber, parte da dificuldade de Malte em compreender a nova realidade que o cerca é a falta de uma continuidade temporal que apresente um processo de transformação entre o mundo da sua infância e o mundo moderno. Assim, a cidade moderna é descrita como "[...] seen through the eyes of a figure out of another world."11 (GARBER, 1970, p. 327). Com a perda de uma noção de continuidade entre passado e presente, Garber levanta a hipótese de que Malte, vendo-se entre esses dois universos, procura criar uma ordem que rompa com os limites impostos pela ideia de fluxo linear do tempo e

que na realidade não a superou, embora em ideia estivesse convencido de sua necessidade, procurando-a instintivamente por tanto tempo, até que ela perdurasse nele e não mais o deixasse? Se for escrito, o livro de Malte Laurids não será nada mais que o livro desta descoberta, mostrada a alguém para quem ela é enorme demais.” (RILKE, 2006, p. 76). A tradução das cartas sobre Cézanne citada nesta pesquisa é de Pedro Süssekind.]

11 “[...] vista pelos olhos de uma figura vinda de outro mundo.” (Tradução nossa). 
torne passado e presente simultâneos através de suas memórias (cf. GARBER, 1970, p. 330331). Essa busca por outra ordem estaria em consonância com uma tentativa do próprio Rilke, indicada pelo estudioso através da citação de uma carta de 1924, na qual o poeta afirma, a respeito de Aufzeichnungen, que na época da escrita do livro buscava uma forma que permitisse retratar a simultaneidade daquilo que passou e daquilo que ainda não emergiu: "Vergangenes und noch nicht Entstandenes einfach als Gegenwärtigkeit letzten Grades aufzufassen fähig wäre."12 (RILKE ${ }^{13}$ apud GARBER, 1970, p. 324). Além disso, Garber afirma que há consonância entre autor e protagonista quanto à tentativa de unificação das divisões de tempo ${ }^{14}$ : de acordo com o estudioso, o romance reflete a busca de Rilke por uma forma textual na qual passado e futuro fossem percebidos simultaneamente como presente, uma forma que Malte também busca criar, em suas anotações, para lidar com a disparidade entre o tempo de sua infância e seu presente. A suposição articulada por Garber de que autor e personagem dividem um mesmo projeto vem corroborar a leitura que se desenrola nesta dissertação, de que os aprendizados que Rilke adquiriu no contato que teve com a obra de diversos artistas - e, em alguns casos, com os próprios artistas - não apenas tornaram-se os aspectos chave em sua escrita lírica, mas também foram elaborados na escrita do romance Aufzeichnungen de duas maneiras entrelaçadas: na estrutura do livro e nas reflexões do protagonista. Embora o tempo ${ }^{15}$ não seja um tema central para a análise aqui feita, ela acrescenta elementos para o debate sobre a forma do romance.

Enquanto Garber argumenta que o problema da temporalidade no romance está ligado a uma nova proposta de escrita, Jock Macleod aponta que a escrita, para Malte, surge em princípio como uma maneira de possuir coisas - ainda que as coisas a serem possuídas sejam suas próprias percepções e lembranças - e de ter domínio sobre elas. Essa disposição está

\footnotetext{
12 “[...] que fosse capaz de compreender o passado e o ainda não ocorrido como um verdadeiro presente." (Tradução nossa).

${ }^{13}$ Da carta de 11 de agosto de 1924 em: Rainer Maria Rilke, Gesammelte Briefe in Sechs Bänden, ed. Ruth Sieber-Rilke e Carl Sieber, Leipzig, 1939-41.

14 "If there is a sense in which the book is autobiography [...], that sense emerges in the recognition that both writer and hero were attempting the same thing, the unification of the varieties of temporal strata into an order which could clarify and give some meaning to the painful disparities in human experience" (GARBER, 1970, pp. 325-326). ["Se há um sentido no qual o livro é autobiográfico [...], esse sentido emerge do reconhecimento de que tanto escritor quanto herói estavam procurando executar o mesmo, a unificação das múltiplas camadas temporais em uma ordem que pudesse esclarecer e dar algum significado para as penosas disparidades da experiência humana.” (Tradução nossa).]

${ }^{15}$ Há outros estudiosos que se detiveram na temporalidade do romance, como G. W. Crowhurst, que analisa a relação entre tempo, memória e experiência nas Aufzeichnungen.
} 
diretamente ligada ao aprendizado do olhar, uma vez que saber ver é uma forma de estar no mundo com os sentidos abertos para absorver os estímulos recebidos onde quer que se esteja $^{16}$. Macleod explicita que, avançando no romance, Malte desenvolve uma visão sobre o amor que toma direção contrária à da escrita: em oposição ao que seria o amor instrumental, ou amar com a intenção de receber amor em retorno, o amor em estado puro seria alcançado por meio do desprendimento (cf. MACLEOD, 1992, p. 421), e uma vez que os modelos de Malte para esse entendimento do amor são escritos de autoras mulheres, ficaria assim desfeita a ideia de escrita como posse e dominação. Como Garber, Macleod reconhece que as ideias de Malte refletem as de Rilke, pois, segundo ele, o aprendizado de Malte a respeito do amor, que acontece na segunda parte das Aufzeichnungen, vai ao encontro do objetivo de Rilke de expressar a existência: "The paradox of writing for Rilke is that, like loving, it is a form of work, a mode of being in the world" ${ }^{17}$ (MACLEOD, 1992, p. 424). Em sua análise das Aufzeichnungen, Rochelle Tobias argumenta que o terror que as experiências na cidade grande provocam em Malte o levam às profundezas de seus medos - da morte, e de uma força maior que ele, à qual está ligado, a que ele se refere como "Das Große"18. E, paradoxalmente, seria quando Malte consegue abandonar-se aos próprios medos que ele encontraria um meio de superá-los pela escrita (cf. TOBIAS, 2013, p. 676).

A escrita se configura como tema moderno no romance, pois ela é problematizada nas Aufzeichnungen seja na forma que Rilke dá ao livro, seja no esforço feito pelo protagonista para afirmar-se como poeta. Malte é um estrangeiro em Paris, e também é testemunha viva de um mundo em vias de extinguir-se ${ }^{19}$ : sua escrita será necessariamente fruto de suas

16 "Seeing here is not an act of interpretation imposed on the raw data of the world, but an opening up of the self, a heightening of the receptivity of the self to sensations from that world. [...] Such a grounding of perception in sensation carries over into Malte's concept of writing. Seeing and writing inhabit the same space for him." (MACLEOD, 1992, p. 405-406). ["Ver não é aqui um ato de interpretação imposto sobre as informações brutas do mundo, mas uma abertura do eu, uma intensificação da receptividade do eu às sensações vindas desse mundo. [...] Tal enraizamento da percepção nas sensações é estendido ao conceito de escrita de Malte. Ver e escrever habitam o mesmo espaço para ele.” (Tradução nossa).]

17 "O paradoxo da escrita para Rilke é que, como amar, é uma forma de trabalho, um modo de estar no mundo." (Tradução nossa).

18 " a coisa grande" (RILKE, 1979, p. 38).

${ }^{19}$ Embora as circunstâncias em que isso tenha ocorrido não sejam explicadas, Malte diz que a casa senhorial deixou de ser de sua família (cf. RILKE, 1982, p. 124) e, quando seu pai morre, afirma que a linhagem dos Brigge terminara, uma vez que ele, Malte, não se reconhece mais como parte dela (cf. RILKE, 1982, p. 127 128). 
percepções desse mundo transformado e do efeito dele em si mesmo ${ }^{20}$ e, para dar conta dessas transformações, as formas tradicionais de narrar se tornaram obsoletas. "Daß man erzählte, wirklich erzählte, das muß vor meiner Zeit gewesen sein."21 (RILKE, 1982, p. 118). Ulrich Fülleborn retoma essa passagem para mostrar que no momento da escrita de Aufzeichnungen, Rilke teria antevisto a impossibilidade da narrativa convencional de dar conta da experiência de um indivíduo em um mundo tornado fragmentado e multifacetado, tornando-se necessário buscar outras formas de escrita que pudessem refletir essas características (cf. FÜLLEBORN, 2000, pp. 326-327). Assim, a forma fragmentada do romance é também reveladora da vivência da metrópole moderna e de seus efeitos naquele que a percorre ${ }^{22}$.

H. R. Klieneberger argumenta que a modernidade do romance de Rilke reside na experimentação com a forma, reveladora de uma desconfiança em relação aos modos tradicionais de narrar. Essa desconfiança era partilhada com alguns de seus contemporâneos, nomeadamente Hugo von Hofmannsthal, Robert Musil e, um pouco mais tarde, Franz Kafka. Klieneberger menciona como exemplo o texto "Ein Brief", escrito por Hofmannsthal em 1901, no qual o fictício Lord Chandos explica que a descrença na língua é o motivo de sua renúncia à escrita literária (cf. KLIENEBERGER, 1979, p. 361). No entanto, Andreina Lavagetto ressalta que, diferentemente de seus contemporâneos e sucessores, a modernidade das Aufzeichnungen não resulta de um desejo de Rilke em romper com as formas tradicionais da narrativa e criar novas formas; ela "[...] não segue as vias da dissolução ensaística (Musil), do fluxo de consciência (Joyce), da recordação (Proust), da parábola (Kafka), para projetar uma narrativa que responda às questões metafísicas colocadas pela nova era." (LAVAGETTO, 2009, p. 954). Segundo a estudiosa, "Rilke parte do nada para chegar a uma narrativa radicalmente moderna [...].", e seu trunfo se deve ao talento lírico de seu autor (cf. LAVAGETTO, 2009, p. 954-955). Lauterbach afirma que se Rilke tivesse evitado aprofundar os conflitos na interioridade do protagonista e limitado o raio de suas reflexões ao contexto da

\footnotetext{
${ }^{20}$ Andreas Huyssen, focando na constituição de Malte como sujeito moderno, argumenta, a partir de teorias psicanalíticas, que Malte não chega a passar pelo processo de fragmentação e dissolução do eu que ocorre com o sujeito na Modernidade, pois ele não teria sequer chegado a constituir um eu durante sua infância (cf. HUYSSEN, 1989, p. 116-117).

21 “Contarem histórias, mas de verdade, isso deve ter sido antes do meu tempo.” (RILKE, 1979, p. 85).

${ }^{22}$ Georg Lukács afirma que a configuração do romance é necessariamente incompleta e dissonante em relação ao mundo; por esse motivo, o romance precisa ser confrontado com a fragmentariedade do mundo, e nisso, porém, “[...] há o perigo de que a fragmentariedade do mundo salte bruscamente à luz e suprima a imanência do sentido exigida pela forma, convertendo a resignação em angustiante desengano, ou então que a aspiração demasiado intensa de saber a dissonância resolvida, afirmada e abrigada na forma conduza a um desfecho precoce que desintegra a forma numa heterogeneidade disparatada, pois a fragmentariedade pode ser apenas superficialmente encoberta, mas não superada." (LUKÁCS, 2003, pp. 71-72).
} 
cidade grande, possivelmente o romance teria sido menos inovador e passado a ser entendido apenas como um sucessor do livro Le Spleen de Paris (1869) de Baudelaire. (LAUTERBACH, 2013, p. 324).

De um modo geral, a maioria dos críticos ressalta a importância do tema do olhar nas Aufzeichnungen para o desenvolvimento de Malte, o protagonista, como escritor. Alguns estudiosos, como Ortrud Gutjahr, Volker Durr e Manfred Koch, argumentam ainda que o aprendizado do olhar e suas implicações estão relacionados à experiência de Rilke com as artes visuais. Gutjahr afirma que Rilke articulou no romance sua própria concepção nova de arte, elaborada a partir da convivência com Rodin. Essa concepção está, de acordo com Gutjahr, baseada em uma nova maneira de olhar ("Die Schule des Sehens"23) que Rilke teria começado a aprender com os artistas da colônia de Worpswede e aprofundado em suas estadias em Paris. O olhar que recusa os julgamentos pré-concebidos se torna, assim, a premissa estética do protagonista para trabalhar na cidade grande (cf. GUTJAHR, 1993, p. 373-374). Segundo a pesquisadora, o poeta reconheceu na obra de Rodin uma resposta ao problema da percepção na Modernidade; Rodin tornara-se para ele o epítome do artista moderno e, sem que seu nome seja mencionado uma única vez no romance, o livro faz referência implícita ao escultor através do tema do aprendizado do olhar (cf. GUTJAHR, 1993, p. 379). Com base nas passagens em que Malte faz observações negativas a respeito da metrópole e expressa medo, Gutjahr argumenta que Malte sente medo de ser obliterado pelas novas impressões da cidade grande, e de que seu trabalho poético não seja relevante. Para contornar o medo, ele narra as imagens que vê quando vaga por Paris, como "[...] ein leeres Papier [...]." ${ }^{24}$ (RILKE, 1982, p. 61). A atividade de narrar também o ajuda a dar sentido a essas novas impressões, que ele não consegue compreender de outras formas, como, por exemplo, pelo mapa da cidade (cf. GUTJAHR, 1993, p. 371). Escrita e visão estariam assim interligados pela experiência nova da Modernidade. Esse entendimento da estudiosa embasa a leitura proposta nesta pesquisa, porém nossa análise se distancia da sua, pois ela toma esse entrelaçamento de olhar e escrita, junto com o tema da memória, como ponto de partida para uma discussão sobre a temporalidade da experiência no romance (cf. GUTJAHR, 1993, p. 384-386), que não será nosso foco. Também Volker Dürr reconhece em Rodin o modelo no qual Rilke se apoia para compor as Aufzeichnungen, e sua hipótese é de que Rilke procura, na

\footnotetext{
23 “A escola do olhar” (Tradução nossa).

24 “[...] um papel vazio [...]” (RILKE, 1979, p. 43).
} 
estrutura narrativa do romance, "traduzir" o tratamento dado por Rodin à superfície de suas esculturas $^{25}$ (cf. DÜRR, 1994, p. 93). Dürr argumenta que, assim como Rodin combinava diversos planos para formar uma escultura, Rilke teria criado planos temáticos em seu romance, que organizam as anotações em unidades maiores. (cf. DÜRR, 1994, p. 94). Já para Manfred Koch, a influência de Rodin na escrita do romance de Rilke é dupla: além do exercício do olhar e do tratamento dado à superfície das esculturas, é tambem a Rodin que se devem as leituras que Rilke fez de Baudelaire. Teria sido a partir de Baudelaire que Rilke compôs uma imagem da Modernidade na qual os habitantes da cidade estão sempre sujeitos à força opressora do seu ambiente (cf. KOCH, 2017, p. 218). As leituras de Ortrud Gutjahr, Volker Dürr e Manfred Koch sugerem que a inovação da forma do romance possibilitava a apreensão de conflitos inerentes à Modernidade. Nas Aufzeichnungen, o protagonista Malte elabora seu próprio projeto estético para lidar com esses conflitos e, em seu processo, evoca os modelos de Baudelaire e Rodin, ainda que o nome deste último não seja mencionado nenhuma vez no livro, como observa Gutjahr (cf. GUTJAHR, 1993, p. 379).

A análise aqui proposta se diferencia dos estudos já existentes, pois trata-se de examinar o projeto estético das Aufzeichnungen de Rilke, como ele se adensa ao longo do livro, entrelaçando o aprendizado do olhar à tarefa da escrita. Busca-se ainda refletir se esse projeto funciona como nó central do romance, dando sentido à miríade de textos que o compõem. Assim, seria possível interrogar em que medida a narrativa fragmentada é em si mesma uma implementação da nova estética anunciada pelo personagem de Rilke. Este capítulo se divide em quatro partes: na primeira, serão traçadas relações entre as Aufzeichnungen e o pensamento de Charles Baudelaire. Dois poemas do autor francês são citados significativamente nas Aufzeichnungen, sendo que um deles, "Une charogne", aborda diretamente ao tema do olhar. Além disso, como será visto na próxima seção, é possível investigar a representação da cidade e de Malte como sujeito e escritor moderno a partir de aproximações ou contraposições à obra de Baudelaire. Na segunda parte do capítulo, serão feitas aproximações entre as Aufzeichnungen e o pensamento de alguns autores do Romantismo alemão, em especial Friedrich Schlegel e Novalis. A terceira parte do capítulo é dedicada à análise de aspectos formais das Aufzeichnungen e, a quarta e última, à análise de quatro temas encontrados no romance e como eles se relacionam: olhar, escrita, experiência e memória. O segundo capítulo da dissertação será dedicado a traçar correspondências entre o

\footnotetext{
${ }^{25}$ Além desse ensaio crítico, Dürr também escreveu outro, igualmente a respeito das Aufzeichnungen, no qual relaciona o romance de Rilke à teoria hegeliana da evolução da consciência estética ocidental.
} 
projeto do romance e alguns dos textos que Rilke escreveu sobre arte, em especial sobre a obra de Rodin e de Cézanne.

\subsection{Malte como flâneur? Rilke, leitor de Baudelaire}

Ulrich Fülleborn afirma que a forma das anotações iniciais do romance, nas quais Malte descreve suas primeiras impressões de Paris, pertencem ao gênero da prosa poética. De acordo com o estudioso, os elementos mais marcantes utilizados por Rilke são os fragmentos densos e compactos em prosa, com inserções abruptas, que se assemelham ao monólogo interior, fechamentos sólidos e distinção rítmica (cf. FÜLLEBORN, 2000, p. 330). Fülleborn aponta que Rilke estava familiarizado com o gênero da prosa poética através da obra de Charles Baudelaire (1821-1867), que é inclusive citada nas Aufzeichnungen duas vezes (cf. FÜLLEBORN, 2000, p. 330). De acordo com Rita Rios, Baudelaire via a prosa poética como um gênero literário novo, “apto a captar o 'espírito' de seu tempo" (RIOS, 2011, p. 91), sobre o qual refletira após ler e reler o conjunto de poemas em prosa escritos por Aloysius Bertrand $^{26}$, Gaspard de la nuit. Fantaisies à la manière de Rembrandt et de Callot, de 1842, que traz reflexões a respeito da arte a partir das representações que os dois artistas mencionados no subtítulo fizeram dela. Os poemas em prosa de Baudelaire são independentes um do outro, retratam cenas cotidianas da vida parisiense tanto das esferas íntimas quanto das públicas, ou trazem reflexões sobre o fazer artístico e poético. Da mesma forma como os poemas em prosa do poeta francês, Andreina Lavagetto considera que as anotações que compõem o romance de Rilke podem ser considerados unidades "com sólida escansão interna, autônomas e completas" que também poderiam ser lidas individualmente (cf. LAVAGETTO, 2009, p. 955). Norbert Fuerst, por sua vez, define o conteúdo do livro como uma sequência de poemas em prosa (cf. FUERST, 1946, p. 463).

Além da prosa poética, as descrições das cenas parisienses nas Aufzeichnungen evocam, como aponta Frederick Garber, a imagem da cidade fixada por Baudelaire na literatura moderna (cf. GARBER, 1970, p. 326). De forma semelhante, as andanças de Malte

\footnotetext{
26 “Foi folheando, pela vigésima vez, no mínimo, o famoso Gaspard de la nuit de Aloysius Bertrand [...] que me veio a ideia de tentar algo análogo, e de aplicar à descrição da vida moderna, ou melhor, de uma vida moderna e mais abstrata, o procedimento que ele havia aplicado à pintura da vida antiga, tão estranhamente pitoresca.

Quem dentre nós não sonhou, nos seus dias de ambição, com o milagre de uma prosa poética, musical, sem ritmo ou rima, flexível e desencontrada o bastante para adaptar-se aos movimentos líricos da alma, às ondulações do devaneio, aos sobressaltos da consciência? É sobretudo da frequentação das cidades enormes, e do cruzamento de suas inumeráveis relações, que nasce este ideal obsessivo.” (BAUDELAIRE apud RIOS, 2011, p. 91-92).
} 
pela cidade, descritas na primeira parte do romance, remontam ao flâneur baudelairiano. Porém, enquanto este é caracterizado como um aficionado pela dinâmica e pelos espaços das grandes cidades, como alguém que se regozija com o fato de estar anônimo e incógnito entre as pessoas que se aglomeram nas ruas - "Sua paixão e sua profissão consistem em esposar $a$ multidão." (cf. BAUDELAIRE, 2010, p. 30, grifo do autor) -, Malte, ao contrário, não demonstra nenhum prazer em estar entre uma multidão: quando, por exemplo, encontra o grupo de foliões ao qual fica preso, o jovem sente repulsa pelas pessoas, por suas risadas, e sente como se o punhado de confetes atirado para o alto lhe queimasse o rosto (cf. RILKE, 1982, p. 43-44).

O aspecto mais relevante do flâneur, para Rilke, não parece ser o apreço pelo espaço urbano em si, mas sim o exercício da sua capacidade da visão no espaço público. Em seu texto de 1863, Le Peintre de la Vie Moderne, Baudelaire descreve o modo como o pintor e desenhista Constantin Guys trabalhava e procura, dessa forma, demonstrar por que motivos era ele o artista que melhor representava, com seu traço, a vida na Paris da segunda metade do século XIX. Guys é retratado como o flâneur por excelência, e sua atividade consistia, essencialmente, no exercício do olhar. Ele era "o observador apaixonado", que percorria o espaço da cidade anonimamente registrando em sua memória tudo o que via em seu caminho. Suas observações se tornavam então matéria para compor seu trabalho artístico, e seu êxito em conseguir reproduzir no papel aquilo que vira anteriormente dependia de sua capacidade de saber ver ${ }^{27}$.

Malte, por sua vez, constata que começa a aprender a ver, e decide dedicar-se à atividade como um estudante aplicado: "Habe ich es schon gesagt? Ich lerne sehen - ja, ich fange an. Es geht noch schlecht. Aber ich will meine Zeit ausnutzen." ${ }^{28}$ (RILKE, 1982, p. 11). São várias as passagens em que Malte descreve em detalhes os locais, as pessoas e as situações por ele vistas na cidade. Uma das mais expressivas abre o romance:

So, also hierher kommen die Leute, um zu leben, ich würde eher meinen, es stürbe sich hier. Ich bin ausgewesen. Ich habe gesehen: Hospitäler. Ich habe einen Menschen gesehen, welcher schwankte und umsankt. Die Leute versammelten sich um ihn, das ersparte mir den Rest. Ich habe eine schwangere Frau gesehen. Sie

\footnotetext{
27 "Poucos são os homens dotados da faculdade da visão; são menos ainda os que possuem a capacidade da expressão. Agora, no momento em que os outros dormem, esse homem está curvado sobre a mesa lançando sobre uma folha de papel o mesmo olhar que há pouco fixava sobre as coisas [...]. E as coisas renascem sobre o papel, naturais, e mais do que naturais; belas, e mais que belas; singulares e dotadas, como a alma do autor, de uma vida em estado de exaltação.” (BAUDELAIRE, 2010, p. 32).
}

28 "Será que já contei isso? Estou aprendendo a ver. Sim, estou começando. Ainda o faço mal. Mas quero aproveitar bem meu tempo.” (RILKE, 1979, p. 6-7). 
schob sich schwer an einer hohen, warmen Mauer entlang, nach der sie manchmal tastete, wie um sich zu überzeugen, ob sie noch da sei. Ja, sie war noch da. Dahinter? Ich suchte auf meinem Plan: Maison d'Accouchement. Gut. Man wird sie entbinden - man kann das. Weiter, rue Saint-Jacques, ein großes Gebäude mit einer Kuppel. Der Plan gab an Val-de-grâce, Hôspital militaire. Das brauchte ich eigentlich nicht zu wissen, aber es schadet nicht. Die Gasse begann von allen Seiten zu riechen. Es roch, soviel sich unterscheidet ließ, nach Jodoform, nach dem Fett von pommes frites, nach Angst. Alle Städte riechen im Sommer. Dann habe ich ein eigentümlich starblindes Haus gesehen, es war im Plan nicht zu finden, aber über der Tür stand noch ziemlich leserlich: Asyle de nuit. Neben dem Eingang waren die Preise. Ich habe sie gelesen. Es war nicht teuer.

Und sonst? ein Kind in einem stehenden Kinderwagen: es war dick, grünlich und hatte einen deutlichen Ausschlag auf der Stirn. Er heilte offenbar ab und tat nicht weh. Das Kind schlief, der Mund war offen, atmete Jodoform, pommes frites, Angst. ${ }^{29}$ (RILKE, 1982, p. 9).

A primeira anotação do livro consiste, portanto, em uma enumeração de locais e situações vistos durante o que parece ser uma dos primeiros passeios de reconhecimento da cidade, uma vez que Malte leva consigo um mapa. O título do romance e o cabeçalho sobre a primeira anotação "11. September, rue Toullier" ${ }^{30}$, denotam que essas cenas não estão sendo narradas à medida que acontecem, mas sim escritas algum tempo depois de terem sido observadas.

Malte compreende que esse exercício do olhar é importante para sua escrita, pois afirma em dado momento que bons versos não são, como acredita o senso comum, criados a partir de sentimentos, e sim de experiências (cf. RILKE, 1982, p. 21). Mas a escrita é para ele também, como mencionado anteriormente, um modo de lidar com o medo. Malte passa a noite toda escrevendo quando decide fazer algo contra o medo (cf. RILKE, 1982, p. 19), um medo que parece ser suscitado pela cidade grande. Além disso, exprime sentimentos de verdadeira repulsa pelos lugares e situações apinhados de pessoas e pela impessoalidade urbana que seduzem o flâneur.

Walter Benjamin, escrevendo sobre Baudelaire, diz que "A rua se torna moradia para o flâneur [...], muros são a escrivaninha onde apoia o bloco de apontamentos; bancas de

29 "Então é aqui que as pessoas vêm viver; eu antes diria que aqui se vem morrer. Hoje saí de casa. E vi: hospitais. Vi um homem cambalear e cair. As pessoas rodearam-no, poupando-me do resto. Vi uma mulher grávida. Arrastava-se pesadamente ao longo de um muro alto e quente, que por vezes apalpava como para certificar-se de que ele ainda estava ali. Estava. E por trás dele? Procurei no meu roteiro: Maison d'Accouchement. Muito bem. Vão partejá-la ali. A isso nada se opõe. Adiante, Rue Saint-Jacques, um edifício grande, com uma cúpula. Meu mapa indicava Val-de-Grâce, Hôpital Militaire. Na verdade nem precisava dessa informação, mas não importa. A rua começou a cheirar mal por todos os lados. Até onde se podia distinguir, cheirava a iodofórmio, a gordura de pommes frites, cheirava a medo. Todas as cidades cheiram mal no verão. Depois vi uma casa singularmente cega, de uma cegueira fixa. Não a encontrei em meu mapa, mas sobre a porta estava escrito, ainda bem legível: Asyle de Nuit. Ao lado da entrada, os preços expostos. Li todos. Não era caro. Que mais? Uma criança num carrinho de bebê parado: era gorda, esverdinhada, com uma nítida erupção na testa, em fase de cura, já não doía mais. A criança dormia, boca aberta respirando iodofórmio, pommes frites, medo.” (RILKE, 1979, p. 5). 
jornais são suas bibliotecas, e os terraços dos cafés, as sacadas de onde, após o trabalho, observa o ambiente.” (BENJAMIN, 2011, p. 35). Malte, porém, por vezes sai de casa contra sua vontade, como quando o fogão enche seu quarto de fumaça. Em outros momentos, refugia-se dentro da Biblioteca Nacional, na qual se sente protegido dos olhares das pessoas pobres que vivem nas ruas, ou seja, é incapaz de transitar com indiferença e tampouco consegue sentir que passa incógnito pela cidade. Assim, Malte se move em Paris como uma espécie de flâneur às avessas: carrega um mapa, caminha a contragosto, olha para a cidade com melancolia, sente-se oprimido pela multidão e é notado no meio dela. Benjamin afirma ainda que "A rua conduz o flâneur em direção a um tempo que desapareceu. Para ele, qualquer rua é íngreme. Ela vai descendo, quando não em direção às Mães, pelo menos rumo a um passado que pode ser tão mais enfeitiçante por não ser seu próprio passado, seu passado particular.” (BENJAMIN, 2009, p. 461-462). Não para Malte: as ruas de Paris o conduzem pela atualidade de um mundo dolorosamente transformado, de um tempo que é e não é o seu. Talvez também por isso ele precise andar pela cidade, porque lhe foram negadas as possibilidades de tornar-se o poeta que gostaria de ser, vivendo no campo, onde escreveria cartas, teria poucos livros e estaria acercado de flores e de um cão. Porque o mundo é outro, não é mais possível ser esse poeta, é preciso ser um poeta flâneur, ainda que contra seu desejo: “Aber es ist anders gekommen, Gott wird wissen, warum. Meine alten Möbel faulen in einer Scheune, in die ich habe stellen dürfen, und ich selbst, ja, mein Gott, ich habe kein Dach über mir, und es regnet mir in die Auge."31 (RILKE, 1982, p. 39). Malte não nasceu na efervescente cidade moderna, ele é filho de uma sociedade antiga e rural, da qual os poucos resquícios que ainda sobrevivem precisam ser deixados de lado, como seus antigos móveis, apodrecendo em um celeiro.

\subsection{Tradição e modernidade: o legado romântico}

Do mesmo modo como é possível argumentar o caráter moderno das Aufzeichnungen e sublinhar os elementos que o ligam à obra de Baudelaire, também é possível traçar aproximações entre o romance rilkeano e o pensamento dos primeiros românticos alemães. Essas aproximações contribuem para mostrar que Rilke não teria se colocado a tarefa de

\footnotetext{
31 "Mas foi tudo diferente, e Deus saberá por quê. Meus velhos móveis apodrecem num depósito em que os coloquei, e eu mesmo, sim, meu Deus, eu mesmo não tenho um teto sobre mim, e chove dentro dos meus olhos." (RILKE, 1979, p. 27).
} 
escrever um romance moderno com o qual buscaria romper radicalmente com os pressupostos formais do gênero, mas sim que, na escrita desse texto, os aprendizados recebidos de Rodin e da pintura de Cézanne estariam sendo postos em diálogo com todo um legado de ideias recebidas de seus antecessores de língua alemã. $\mathrm{O}$ debate em torno da vinculação do romance a uma tradição romântica alemã em contraste com seu caráter moderno não é o foco desta pesquisa. Porém, é interessante observar, ainda que brevemente, que elementos chave para a nossa análise das Aufzeichnungen se aproximam de conceitos fundamentais para os primeiros românticos alemães ${ }^{32}$.

Por exemplo, a escolha pelo texto em fragmento, feita por Rilke para as Aufzeichnungen, é essencial para os irmãos Friedrich e August Schlegel e para Novalis. Márcio Suzuki afirma que, para estes, “[...] a descoberta do fragmento como forma é uma tentativa de solucionar problemas de natureza filosófica" (SUZUKI, 1997, p. 16). F. Schlegel procurava demonstrar que a consciência humana possui uma inclinação à fragmentação, uma vez que os indivíduos vivem a contradição de terem tudo dentro de si e ao mesmo tempo se sentirem limitados, por serem eles próprios fragmentados. Assim, a forma do fragmento seria para Schlegel, de acordo com Suzuki, a "forma da filosofia universal" (cf. SUZUKI, 1997, p. 14-16). Schlegel escreveu ainda, no fragmento 24 da revista Athenäum que "Muitas obras dos antigos se tornaram fragmentos. Muitas obras dos modernos já o são ao surgir." (SCHLEGEL, 1997, p. 51). Segundo Suzuki, pode-se compreender essa afirmação à luz do problema que os românticos encontravam na divisão dos gêneros poéticos, uma vez que um poeta que procurasse abarcar em sua obra toda a poesia não poderia separar os gêneros e, como consequência, não haveria forma definida (cf. SUZUKI, 1997, p. 15). Curiosamente, embora o caráter fragmentário do romance seja um ponto que liga as Aufzeichnungen ao pensamento que seus antecessores vinham desenvolvendo quase cem anos antes, ele também é um dos principais pontos que levaram diversos críticos a considerar esse livro de Rilke como um dos precursores da modernidade literária em língua alemã. Hugo Friedrich argumenta que é possível perceber reverberações do Romantismo nas produções de gerações posteriores, mesmo entre aquelas que buscavam romper com ele. Friedrich conclui, com isso, que “A poesia moderna é o Romantismo desromantizado.” (FRIEDRICH, 1991, p. 30).

\footnotetext{
${ }^{32}$ H. R. Klieneberger desenvolve a hipótese de que, apesar de ser considerado um pioneiro da modernidade literária, Rilke é também herdeiro da tradição romântica tanto em sua poesia quanto em sua ficção, mas seu argumento é de que ele dá continuidade a essa tradição através da mitificação da figura do artista, que teria, argumenta o estudioso apoiando-se na teoria freudiana, uma origem narcísica (cf. KLIENEBERGER, 1979, p. 363-364)
} 
As possíveis aproximações entre as Aufzeichnungen e o pensamento dos autores românticos estende-se também ao tema do aprendizado do olhar. O exercício do olhar está, para Malte, ligado tanto ao que se passa a seu redor como à sua interioridade e, portanto, investiga a si mesmo tão intensamente quanto a cidade e seus habitantes. Espaço externo e interno ecoam um ao outro: em uma caminhada, Malte observa hospitais e pessoas em seus arredores, o que o leva a refletir sobre a morte, fazendo considerações sobre a diferença entre a morte nas grandes cidades e a morte em sua terra natal; essa reflexão, por sua vez, o conduz à lembrança da morte do avô (cf. RILKE, 1982, p. 9-14). Com esse jogo de dentro e fora, de olhar para si e para outrem, Malte elabora um conhecimento sobre si mesmo, do qual ele precisa para explorar suas próprias potencialidades como autor. Embora ele reitere diversas vezes sua solidão na cidade, esse processo não é totalmente individual como pode parecer à primeira vista: seus encontros fortuitos com outros habitantes de Paris, suas memórias de relações passadas e as leituras que faz de outros autores acrescentam novas facetas à sua descoberta do aprendizado do olhar e, com ele, de sua própria interioridade. Em Gespräch über die Poesie, texto de 1800, Friedrich Schlegel, partindo da ideia de que a poesia é intrínseca à natureza do homem, e que por isso seria um denominador comum entre pessoas de origens diferentes, afirma que o homem, para aproximar-se de um entendimento mais abrangente da humanidade, deve buscar em outrem o complemento de sua própria essência, fazendo assim um movimento de sair de si para voltar a si mais íntegro do que antes ${ }^{33}$.

Esse movimento de sair de si e retornar a si é tomado como um processo formativo (Bildung) individual. Quanto a isso, Novalis escreve: “Anos de aprendizado são para o novato poético - anos acadêmicos para o filosófico.” (NOVALIS, 2001, p. 37), enquanto Schelling afirma: "É preciso, em geral, que se possa chegar ao objetivo por mais de um caminho. Cada um por aquele que é todo seu, [...] pois em nenhum lugar os direitos da individualidade [...] valem mais do que aqui” (SCHLEGEL, 1994, p. 56). Essa formação própria, individualizada, seria a construção de um caminho através do qual o artista poderia explorar ao máximo suas potencialidades e, no caso dos poetas, seria necessária para que estes pudessem produzir uma obra não totalmente apoiada apenas em seus sentimentos, mas também em sua experiência de mundo e na experiência compartilhada socialmente: uma obra que pudesse ser a um só tempo particular e universal. Essa concepção do fazer poético vai ao encontro do que afirma o

\footnotetext{
33 “[...] nenhum homem é apenas um homem, pois pode e deve ser, ao mesmo tempo, verdadeira e efetivamente, toda a humanidade. Por isso o homem, seguro de que irá se reencontrar, volta-se sempre de novo para fora de si mesmo, para obter o complemento de sua mais funda natureza nas profundezas de outrem." (SCHLEGEL, 1994, p. 30)
} 
protagonista de Rilke, ainda no início do romance, na passagem em que reflete sobre a escrita literária. Após rever sua produção artística, Malte conclui que seus versos, que escreveu quando era jovem demais, não têm grande valor, uma vez que, em sua visão, foram escritos seguindo uma ideia equivocada de poesia. Segundo ele, bons versos, contrariamente ao que pensa o senso comum, não devem ser compostos a partir de sentimentos, mas sim de inúmeras experiências de diferentes tipos, acumuladas ao longo da vida ${ }^{34}$.

Essa convicção de Malte a respeito da criação artística é a mesma que o leva a exercitar o aprendizado do olhar. Não basta ter toda sorte de experiências, é preciso saber vêlas para absorvê-las o mais integralmente possível e atingir um entendimento mais abrangente da condição humana e, com isso, compor versos que contenham algo de verdadeiro sobre a existência, mesmo que individual. Assim, Malte, nesse fragmento, não está apenas refletindo sobre a poesia e o processo criativo, está também, ao mesmo tempo, traçando o seu próprio plano de aprendizado e de investigação de suas memórias de maneira a obter material para sua escrita. A enumeração de vivências que Malte julga como importantes, ou mesmo necessárias, para sentir-se apto a escrever versos, ecoa as considerações que Novalis faz a respeito do processo de sair de si para voltar a si, que levaria ao conhecimento do eu verdadeiro. Nele, o exercício do olhar, embora não sozinho, também tem papel essencial: é preciso ver muitos rostos, reparar em suas feições, é preciso escutar o som de determinadas palavras, é preciso

\footnotetext{
34 "Denn Verse sind nicht, wie die Leute meinen, Gefühle (die hat man früh genug), - es sind Erfahrungen. Um eines Verses willen muß man viele Städte sehen, Menschen und Dinge, man muß die Tiere kennen, man muß fühlen, wie die Vogel fliegen, und die Gebärde wissen, mit welchen die kleinen Blumen sich auftun am Morgen. Man muß zurückdenken können an Wege in unbekannten Gegenden, an unerwartete Begegnungen und an Abschiede, die man lange kommen sah, - an Kindheitstage, die noch unaufgeklärt sind, an die Eltern, die man kränken mußte, wenn sie einem eine Freude brachten und man begriff sie nicht (es war eine Freude für einen anderen -), an Kinderkrankheiten, die so seltsam anheben mit so vielen tiefen und schweren Verwandlungen, an Tage in stillen, verhaltenen Stuben und an Morgen am Meer, an das Meer überhaupt, an Meere, an Reisenächte, die hoch dahinrauschten und mit allen Sternen flogen, - und es ist noch nicht genug, wenn man an alles das denken darf. Man muß Erinnerungen haben an viele Liebesnächte, von denen keine der andern glich, an Schreie von Kreißenden und an leichte, weiße, schlafende Wöchnerinnen, die sich schließen. Aber auch bei Sterbenden muß man gewesen sein, muß bei Toten gesessen haben in der Stube mit dem offenen Fenster und den stoßweisen Geräuschen." (RILKE, 1982, p. 21). ["Pois versos não são, como as pessoas imaginam, sentimentos (a esses, temos cedo demais) - são experiências. E por causa de um verso é preciso ver muitas cidades, pessoas e coisas, é preciso conhecer bichos, é preciso sentir como voam os pássaros, e saber com que gestos flores diminutas se abrem ao amanhecer. É preciso poder recordar caminhos em regiões desconhecidas, encontros inesperados, e despedidas que há muito sentíamos chegar - dias da infância, ainda não explicados, os pais que tínhamos de magoar quando nos davam alguma alegria e não a entendíamos (era uma alegria para outra pessoa), doenças de criança que começavam de modo tão singular, com tantas e tão profundas transformações, dias em quartos silenciosos e isolados, manhãs no mar, o mar sobretudo, mares, noites de viagem rumorejando no alto e voando com todas as estrelas - e poder pensar em tudo isso ainda não é suficiente. É preciso ter lembranças de muitas noites de amor, nenhuma semelhante à outra, gritos de mulheres dando à luz, leves e alvas parturientes adormecidas que se tornavam a fechar. E também é preciso ter estado com moribundos, sentar-se junto aos mortos no quartinho com a janela aberta, e aqueles ruídos intermitentes." (RILKE, 1979, p. 14-15).
} 
dedicar atenção a muitas leituras - é preciso dedicar-se a penetrar em diversas experiências com todos os sentidos aflorados ${ }^{35}$.

O processo de aprendizado do olhar de Malte e seus desdobramentos dão às Aufzeichnungen uma dimensão formativa, mas o livro dificilmente pode ser considerado um Bildungsroman ${ }^{36}$, se tomarmos como parâmetro a acepção dada ao termo por Wilhelm Dilthey a propósito do Wilhelm Meisters Lehrjahre de Goethe, livro de 1796 sobre o qual Dilthey escreveu que "mostra aperfeiçoamento [Ausbildung] humano em diversas etapas, configurações e fases da vida." (DILTHEY ${ }^{37}$ apud MAZZARI, 2010, p. 97). As Aufzeichnungen de Rilke mostram o desdobramento do novo aprendizado de Malte, o olhar, e do novo entendimento a respeito da escrita que acompanha esse aprendizado, que ocorrem no período em que Malte vive em Paris e escreve as anotações que compõem o romance. $\mathrm{O}$ passado de Malte é tratado apenas em partes, através dos relatos de suas lembranças, as quais pouco ou quase nada revelam de sua formação no período da infância. Também não há, ao contrário de Wilhelm Meister, uma mudança significativa que parece operar-se no protagonista e leva a uma guinada em sua trajetória. Tampouco se aplica a formulação de Hegel sobre o gênero romanesco, feita em seu curso de estética, de que, ao fim dos anos de aprendizado “[...] o indíviduo apara suas arestas, integra-se com os seus desejos e opiniões nas relações vigentes e na racionalidade das mesmas, ingressa no encadeamento do mundo e conquista nele uma posição adequada." (HEGEL ${ }^{38}$ apud MAZZARI, 2010, p. 100). No caso do romance de Rilke, inexiste essa conciliação com a sociedade. Na segunda parte do

\footnotetext{
35 "O ser humano é capaz de ser em cada instante um ser supra-sensível. [...] Sem dúvida a clareza de consciência nesse estado, o achamento de Si Mesmo - é muito difícil [...]. Quanto mais, porém, somos capazes de estar conscientes desse estado, mais vital, potente e satisfatória é a convicção, que nasce daí - a crença em genuínas revelações do espírito. Não é nenhum ver - ouvir - sentir - é composto de todos os três - mais que todos os três - uma sensação de imediata certeza - uma inspeção de minha vida mais verdadeira, mais própria [...]. Notável se torna o fenômeno particularmente à vista de muitas figuras e rostos humanos - especialmente à contemplação de muitos olhos, muitas feições, muitos movimentos - à audição de certas palavras, à leitura de certos trechos - a certas perspectivas sobre a vida, o mundo e o destino. Muitíssimos acasos, muitos acontecimentos naturais, certos particulares tempos do ano e do dia, fornecem-nos tais experiências." (NOVALIS, 2001, p. 49-51).
}

${ }^{36}$ Norbert Fuerst, no entanto, escreveu em 1946 um ensaio crítico no qual argumenta que as Aufzeichnungen poderiam ser compreendidas como um romance de formação não de Malte, mas de Rilke, no qual ele próprio tenha elaborado as transformações pelas quais passava no período em que escrevera o romance (cf. FUERST, 1946, p. 471-472).

${ }^{37}$ Wilhelm Dilthey, Leben Schleiermachers, Martin Redeker (org.), Göttingen, Vandenhoeck \& Ruprecht, 1991, p. 317 .

${ }^{38}$ Ästhetik, Berlim/Weimar, Aufbau, vol. I, segunda parte, terceira seção, p. 567. 
romance, Malte se afasta gradativamente do mundo circundante, mergulhando na biografia de personagens históricos e na obra de outros escritores.

Em contrapartida, Andreas Huyssen lembra que alguns críticos analisam as Aufzeichnungen como um exemplar do gênero do Künstlerroman ${ }^{39}$ (cf. HUYSSEN, 1989, p. 115). O gênero definido por Herbert Marcuse como o romance de formação do artista, cujo pressuposto é o conflito entre arte e vida, entre artista e mundo circundante (cf. KANGUSSU, 2005, p. 346). Imaculada Kangussu dinstingue duas vertentes do Künstlerroman, “o 'subjetivo-romântico' e o 'objetivo-realista'.” (KANGUSSU, 2005, p. 352). A primeira abarca autores do Sturm und Drang, do Simbolismo francês, autores adeptos do esteticismo l'art pour l'art e os primeiros românticos alemães, e "[...] tende a submeter a existência empírica a ideais estéticos irrealizáveis e, com isso, levar ao abandono da vida prosaica em nome da arte." (KANGUSSU, 2005, p. 352). Kangussu, citando Marcuse, ressalta ainda que Tieck, Schlegel e Novalis “[...] criam uma realidade poetizada, um mundo de sonhos que não é mais um problema para o artista.” (KANGUSSU, 2005, p. 352). A história de Malte que se desenrola nas Aufzeichnungen poderia talvez ser aproximada às obras desses escritores, pelo fato de que existe um conflito entre o protagonista de Rilke e o mundo em que ele vive, e de que ele não participa das atividade cotidianas do restante dos habitantes da cidade. É interessante traçar uma relação entre as Aufzeichnungen e a tradição do Künstler- e do Bildungsroman para refletir sobre o quanto o romance de Rilke, apesar de seu caráter moderno, também se relaciona com seus predecessores. Apesar dos pontos em comum com o Künstlerroman, nas Aufzeichnungen Rilke retrata a busca do poeta Malte para separar-se totalmente da sociedade para dedicar-se a escrever dia e noite, sem todavia ser capaz de criar para si uma realidade própria. Ainda que na segunda parte do romance o tema da cidade se torne mais escasso em favor das memórias e leituras, o conflito não se resolve, ele permanece como um pano de fundo para essas reflexões que são parte de sua atividade de escrita.

\subsection{As Aufzeichnungen}

Nesta análise, o romance Die Aufzeichnungen não será lido como Künstlerroman, apesar de ele possuir um aspecto formativo importante para esta pesquisa, o do aprendizado do olhar ("sehen lernen"). Esse aprendizado será tratado aqui como elemento programático do

\footnotetext{
${ }^{39}$ Huyssen cita Dimensions of the Modern Novel, de Theodore Ziolkowski (cf. HUYSSEN, 1989, p. 115).
} 
desenvolvimento do personagem. Em uma primeira leitura, o livro pode parecer um caleidoscópio de assuntos diversos apenas vagamente conectados entre si pela figura do narrador personagem, cujo nome figura no título, Malte Laurids Brigge. Die Aufzeichnungen formam um romance que demanda uma grande disposição de seus leitores, pois ele exige uma ou mais releituras. Outra dificuldade diz respeito à referencialidade do texto: muitas referências são feitas de forma implícita, impondo ao leitor a necessidade de pesquisar menções e citações feitas no texto e de buscar notas e comentários de editores ou tradutores. A partir da releitura, as conexões temáticas tornam-se mais aparentes, e o que antes poderia parecer um conjunto de fragmentos desconexos começa a revelar a construção de uma reflexão estética voltada a investigar novas possibilidades de escrita. ${ }^{40}$

Embora sejam classificadas como romance, as Aufzeichnungen não se enquadram facilmente nas convenções do texto romanesco. Como o próprio título sugere, a unidade narrativa é abandonada por completo e, ao invés de um enredo bem definido, que se desenrola de maneira linear a partir de relações de causalidade, o leitor do romance rilkeano encontra uma sequência de textos fragmentados, organizados de maneira aparentemente arbitrária. Malte, o narrador protagonista do romance, tece reflexões de naturezas diversas, indo desde temas abrangentes como o amor, a morte, a vida moderna e a arte, até os de ordem individual, como seus sentimentos, memórias e impressões da cidade em que vive. Dorothea Lauterbach elenca três instâncias principais de tempo e espaço ao longo das anotações: o momento presente de Malte, na Paris da virada do século; suas lembranças da infância, na Dinamarca antiga; e as reconstruções narrativas que ele faz de figuras históricas de diferentes épocas e locais, a partir de suas leituras. O elemento que dá coesão a essa variedade de esferas

\footnotetext{
${ }^{40}$ Há diversos estudos na área da crítica genética e da crítica psicanalítica dedicados a investigar a fabricação do texto. Por exemplo: RYAN, Judith. “'Hypothetisches Erzählen': Zur Funktion von Phantasie und Einbildung in Rilkes 'Malte Laurids Brigge'”. In: ENGELHARDT, Hartmut (org.). Materialien zu Rainer Maria Rilke "Die Aufzeichnungen des Malte Laurids Brigge". Frankfurt am Main: Suhrkamp, 1974; MARTENS, Lorna. "Autobiographical Narrative and the Use of Metaphor: Rilke's Techniques in Die Aufzeichnungen des Malte Laurids Brigge". Studies in Twentieth Century Literature, 9.2, 1985; MARTENS, Lorna. "Reliable Narration: Rainer Maria Rilke's Die Aufzeichnungen des Malte Laurids Brigge". In: The Diary Novel. New York: Cambridge Univsersity Press, 1985; KANT, Roswitha M., Visualität in Rainer Maria Rilkes Die Aufzeichnungen des Malte Laurids Brigge: Eine Untersuchung zum psychoanalytischen Symbolbegriff. Frankfurt am Main: Peter Lang, 2002; VÖLTZ, Heide. "Realität" und "Fiktion" aus systemtheoretischer Perspektive in Rainer Maria Rilkes Die Aufzeichnungen des Malte Laurids Brigge und Duineser Elegien. Stuttgart: Hans-Dieter Heins, 2003; LINDEN, Patricia. “*Im Manuskript an den Rand geschrieben": Spiegelschrift und Marginalität in Rainer Maria Rilkes Die Aufzeichnungen des Malte Laurids Brigge. Tübingen: Francke, 2005; RICHTER, Thomas. "Textgenetische Edition der Entwurfshandschrift zu Rilkes Aufzeichnungen des Malte Laurids Brigge. Ein Werkstattbericht". In: Passim. Bulletin des Schweizerischen Literaturarchivs 6, 2010; RICHTER, Thomas. “'diese amorphe Sprache': Versuch einer Systematisierung der Streichungen in Rilkes Entwurfshandschrift zu den Aufzeichnungen des Malte Laurids Brigge". In: GISI, Lucas Marco (org.). Schreiben und Streichen. Zu einem Moment produktiver Negativität. Göttingen: Wallstein, 2011.
} 
narrativas, de acordo com a estudiosa, é a subjetividade do protagonista que escreve as anotações, Malte Laurids Brigge (cf. LAUTERBACH, 2013, p. 322).

O livro compreende, ao todo, 71 anotações, não numeradas, separadas apenas por um espaçamento na página. Algumas anotações são curtas, como a segunda e a terceira, nas quais Malte trata dos barulhos e do silêncio na cidade, respectivamente (cf. RILKE, 1982, p. 9-10). Outras são bastante extensas, como, por exemplo, a décima quinta, na qual narra as idas a Unerkloster, à casa do avô materno, o Graf Brahe (cf. RILKE, 1982, p. 25-35). Os temas muitas vezes mudam significativamente de uma para outra, mas pode-se notar que Rilke lançou mão de alguns artifícios narrativos para encadeá-las. Ainda assim, é um encadeamento precário e, a princípio, o fluxo das ideias expressadas por Malte parece não levar a um aprofundamento ou desenvolvimento efetivo de qualquer uma delas. Lauterbach aponta que Rilke faz encadeamentos temáticos ou linguísticos, que por vezes coincidem, como ocorre do final da anotação 62 (no qual trata da encenação dos irmãos missionários) até a anotação 65. Essa sequência é unificada pelo tema do teatro, que serve também como metáfora para modos de estar no mundo criticados por Malte (cf. LAUTERBACH, 2013, p. 322-323).

Na primeira anotação do livro, o tema da morte e do sofrimento anônimos surge nas primeiras linhas a partir da visão dos hospitais da cidade e das pessoas fragilizadas no ambiente público: "So, also hierher kommen die Leute, um zu leben. Ich würde eher meinen, es stürbe sich hier. Ich bin ausgewesen. Ich habe gesehen: Hospitäler."41 (RILKE, 1982, p. 9). O nome de um dos hospitais vistos, Hôtel-Dieu, é recuperado na sexta anotação, trazendo consigo um novo tema, o do medo, inspirado por essa situação - "Es wäre sehr häßlich, hier krank zu werden, und fiele es jemandem ein, mich ins Hôtel-Dieu zu schaffen, so würde ich dort gewiß sterben." ${ }^{42}$ (RILKE, 1982, p. 12). A partir daí, o tema da morte vai sendo desdobrado até a décima anotação, a partir de diferentes pontos, como, por exemplo, em uma reflexão sobre a morte na cidade grande - "Wer giebt heute noch etwas für einen gut ausgearbeiteten Tod? Niemand."43 (RILKE, 1982, p. 13) - ou em uma longa reminiscência da morte do avô paterno: "Meinem Großvater noch, dem alten Kammerherrn Brigge, sah man es

\footnotetext{
41 "Então é aqui que as pessoas vêm viver; eu antes diria que aqui se vem morrer. Hoje saí de casa. E vi: hospitais." (RILKE, 1979, p. 5).

42 "Seria péssimo adoecer neste lugar, e se alguém se lembrasse de me transportar ao Hôtel de Dieu eu certamente morreria lá.” (RILKE, 1979, p. 7-8).

43 “Quem, hoje, dá valor a uma morte bem executada? [Ninguém.]” (RILKE, 1979, p. 8).
} 
an, daß er einen Tod in sich trug. Und was war das für einer: zwei Monate lang und so laut, daß man ihn hörte bis aufs Vorwerk hinaus." $" 44$ (RILKE, 1982, p. 14).

Outro procedimento de encadeamento apontado por Lauterbach, que aparece quando as associações temáticas não existem, é a inserção de frases de referência que ligam vários assuntos distintos através do ponto de vista de Malte (cf. LAUTERBACH, 2013, p.322). Na segunda parte do romance, no processo de rememorar leituras e acontecimentos de sua infância, Malte permeia suas narrativas com colocações pontuais que comparam seu entendimento da época do ocorrido e o posterior: "So seh ich es jetz, damals aber machte es mir vor allem Eindruck [...]"45 (RILKE, 1982, p. 153); "So ist mir klar geworden, daß ich nie ein richtiger Leser war." ${ }^{46}$ (RILKE, 1982, p. 156); "[...] ich konnte nicht begreifen, wie man es über sich brachte, so viel Welt zu versäumen." ich, was ich jetzt begreife [...]"48 (RILKE, 1982, p. 177); “[...] das begreife ich jetzt [...]"49 (RILKE, 1982, p. 181). Essas repetições reforçam que é a subjetividade de Malte que mantém a coesão entre anotações díspares, e sugerem que as novas experiências em Paris e o aprendizado do olhar tenham contribuído para que ele passasse a ver suas experiências e leituras anteriores sob uma nova ótica.

Em um primeiro momento, o romance pode ser confundido com um diário. O livro abre com um cabeçalho indicando data e lugar: "11. September, rue Toullier.” (RILKE, 1982, p. 9). Além do cabeçalho, as narrativas que reconstroem retrospectivamente o que já foi visto ou vivido corroboram a impressão do diário. Porém, os cabeçalhos desaparecem - há apenas mais dois, um indicando apenas local (cf. RILKE, 1982, p. 35), o outro indicando apenas tratar-se de um rascunho de carta (cf. RILKE, 1982, p. 61) - e as reflexões passam a abandonar o caráter de pura reminiscência e passam a desenvolver pensamentos estéticos ou filosóficos. Outras anotações parecem ainda exercícios de escrita. Se à primeira vista o leitor pode sentir que está em terreno conhecido - o do diário íntimo -, essa impressão vai se esvanecendo rapidamente à medida que a leitura avança.

\footnotetext{
44 "Meu avô, o Camareiro Brigge, carregava - e isso era coisa que se via - sua morte dentro de si. E que morte! Durou dois meses, e foi tão ruidosa que até do lado de fora da propriedade a escutavam.” (RILKE, 1979, p. 9).

45 “Agora vejo tudo assim, mas daquela vez o que mais me impressionou [...]" (RILKE, 1979, p. 110).

46 “Assim, entendi com clareza que nunca fui um verdadeiro leitor." (RILKE, 1979, p. 113).

47 “[...] não podia entender que alguém fosse capaz de desperdiçar tanto mundo.” (RILKE, 1979, p. 115).

48 “Daquela vez vivi o que hoje compreendo [...]" (RILKE, 1979, p. 128).

49 “Agora entendo [...]” (RILKE, 1979, p. 131).
} 
Em uma carta de 11 de abril de 1910, Rilke escreveu à condessa Manon zu SolmsLaubach uma reflexão sobre seu romance recém publicado:

\begin{abstract}
Ich weiß nicht, wieweit man aus den Papieren auf ein ganzes Dasein wird schließen können. Was dieser erfundene junge Mensch innen durchmachte (an Paris und an seinen über Paris wieder auflebenden Erinnerungen), ging überall so ins Weite; es hätten immer noch Aufzeichnungen hinzukommen können; was nun das Buch ausmacht, ist durchaus nichts Vollzähliges. Es ist nur so, als fände man in einem Schubfach ungeordnete Papiere und fände eben vorderhand nicht mehr und müßte sich begnügen. Das ist, künstlerisch betrachtet, eine schlechte Einheit; aber menschlich ist es möglich, und was dahinter aufsteht, ist immerhin ein Daseinsentwurf und ein Schattenzusammenhang sich rührender Kräfte. (RILKE apud LAUTERBACH, 2013, p. 324). ${ }^{50}$
\end{abstract}

Apesar de ser uma reflexão posterior à escrita do livro, Rilke cria na carta uma imagem mais condizente com a forma final das Aufzeichnungen do que a do diário: a de um conjunto de escritos soltos, esparsos, que foram organizados, possivelmente por alguém diferente de quem os escreveu, depois de terem sido acumulados. Há elementos que indicam o trabalho de um editor: além dos três cabeçalhos, seis das anotações têm trechos deixados entre parênteses e com uma nota que diz "Im Manuskript an den Rand geschrieben." ("Escrito à margem do manuscrito"). Como são quase todas anotações da segunda parte do romance, com exceção de uma (são elas: 33, 54, 55, 60, 64, 70; a segunda parte do romance se inicia na trigégima oitava anotação), esse recurso narrativo pode dar ao leitor a impressão de que se trata de uma decisão do editor em publicar um trecho rasurado por Rilke, e levá-lo, talvez, a supor que o autor não tenha podido completar o manuscrito como teria sido esperado. Ou ainda, de que se trata de um trabalho aberto, ainda em construção, e não de um texto concluído, como indica Rilke na carta citada acima. Há uma tensão entre a forma aberta das anotações e as formas do romance e do livro impresso, necessariamente definitivas e delimitadas.

Além disso, a caracterização do protagonista e da situação em que vive parece ser circunstancial: através de indícios e de afirmações feitas no decorrer do livro é possível construir uma imagem de Malte que, todavia, permanece repleta de lacunas. Sabemos que ele é um jovem dinamarquês de origem aristocrática, último indivíduo de sua linhagem familiar, que é poeta e vive, aos 28 anos, pobre e sozinho em Paris, sem que seja dito em nenhum momento como ele chegou a esse estado. Mas os motivos que o levaram a Paris e à pobreza

\footnotetext{
50 "Não sei o quanto se pode depreender a partir de documentos de toda uma existência. O que esse jovem fictício vivenciou internamente (em Paris e em suas lembranças revividas sobre Paris) foi longe e para toda parte; poderia sempre continuar a acrescentar anotações; o que constitui o livro agora não é algo completo. É apenas como alguém que encontrasse papéis desordenados dentro de uma gaveta, e no momento não encontrasse mais nenhum e precisasse se contentar [com isso]. Isso, considerado artisticamente, é uma unidade ruim; mas humanamente, é possível, e o que está por trás disso, afinal, é uma concepção de existência e uma conexão de nuances em contato." (Tradução nossa).
} 
talvez sejam menos importantes que o fato inquestionável de que sua família foi engolida pelas mudanças que ocorreram no mundo, e seu nome não significa mais nada na sociedade moderna. Se Malte ainda fosse nobre, o anonimato não seria uma possibilidade, não poderia afetar sua trajetória poética. Na cidade moderna, essa condição é contingente, por vezes inevitável, e Malte precisa aprender a lidar com ela.

A fragmentariedade do livro se dá, principalmente, no abandono de um enredo linear, mas há outros aspectos que a intensificam, como a alternância de instâncias temporais e espaciais, e de focos narrativos. Algumas das anotações não são escritas totalmente em primeira pessoa. São passagens em que, após o personagem narrador fazer considerações sobre si, o narrador em primeira pessoa é substituído pelo narrador onisciente. Um exemplo é a anotação 55, perto do final do romance, na qual Malte narra a morte e a desaparição do corpo do duque Karl der Kühne, após ter relembrado, na anotação anterior, um livro de capa verde que havia lido na infância. $\mathrm{O}$ foco da narrativa passa gradativamente do narrador personagem para o narrador onisciente:

Wenn ichs nun bedenke, so scheint es mir seltsam, daß in demselben Buche der Ausgang dessen erzählt wurde, der sein ganzes Leben lang Einer war, der Gleiche, hart und nicht zu ändern wie ein Granit und immer schwerer auf allen, die ihn ertrugen. Es giebt ein Bild von ihm in Dijon. Aber man weiß es auch so, daß er kurz, quer, trotzig war und verzweifelt. Nur an die Hände hätte man vielleicht nicht gedacht. Es sind arg warme Hände, die sich immerfort kühlen möchten und sich unwillkürlich auf Kaltes legen, gespreizt, mit Luft zwischen allen Fingern. In diese Hände konnte das Blut hineinschießen, wie in einem zu Kopf steigt, und geballt waren sie wirklich wie die Köpfe von Tollen, tobend von Einfällen.

Es gehörte unglaubliche Vorsicht dazu, mit diesem Blute zu leben. Der Herzog war damit eingeschlossen in sich selbst, und zuzeiten fürchtete ers, wenn es um ihn herumging, geduckt und dunkel. Es konnte ihm selber grauenhaft fremd sein, dieses behende, halbportugiesische Blut, das er kaum kannte. ${ }^{51}$ (RILKE, 1982, p. 151-152).

Nessa passagem, como em outras, presentes na segunda parte do romance, Malte narra parte da vida de uma figura histórica a partir de uma leitura feita previamente. Aqui, Malte não faz suposições a respeito do duque, e sim descreve diretamente como se estivesse certo de que os

\footnotetext{
51 "Quando reflito nisso, parece-me estranho que no mesmo livro se relatasse a morte daquele que durante toda a vida foi um só, o mesmo, duro e imutável como um granito, cada vez mais pesado para aqueles que o tinham de suportar. Há um retrato dele em Dijon. Mas, mesmo sem isso, vemos que era baixo, torto, teimoso e desesperado. Talvez seja só nas mãos que não se tenha pensado. São mãos muito quentes, querendo refrescar-se a toda hora, e repousam involuntariamente sobre coisas frias, espalmadas, com ar quente entre todos os dedos. $\mathrm{O}$ sangue por vezes jorrava nessas mãos, assim como sobe em um rosto, e elas se fechavam realmente como crânios de loucos, cheios de ideias selvagens.

Era preciso uma inacreditável cautela para conviver com esse sangue. $\mathrm{O}$ duque estava encerrado em si mesmo com ele, por vezes temia-o, quando, agachado e sombrio, circulava em seu corpo. E podia tornar-se sinistramente estranho para ele mesmo, esse sangue veloz, meio português, que ele nem conhecia." (RILKE, 1979, p. 109).
} 
eventos tenham se passado dessa maneira. Na metade da anotação, há outra breve inserção de Malte a respeito de si mesmo: "So seh ich es jetzt, damals aber machte es mir vor allem Eindruck, von dem Dreikönigstag zu lesen, da man ihn suchte." ${ }^{52}$ (RILKE, 1982, p. 153). No romance predominam as anotações escritas em primeira pessoa, e as que são escritas em terceira pessoa, as reconstruções de personagens históricos, contêm essas afirmações de Malte sobre seu próprio entendimento. Essas afirmações pessoais são os elementos que conectam essas narrativas, que revelam que Malte está menos preocupado em aludir a fatos históricos precisos do que em narrar suas próprias experiências de leitura.

Uma exceção é o trecho em que narra a história de seu vizinho, Nikolaj Kusmitsch, a partir não de uma leitura, mas de uma narrativa contada a ele pelo amigo do vizinho, com quem Malte teve a oportunidade de conversar (cf. RILKE, 1982, p. 134-140). A situação vivida pelo vizinho afeta bastante Malte, que passa a ficar atento aos traços de sua presença que lhe são perceptíveis, em especial aos sons que chegam de seu quarto. Malte narra a história de Nikolaj Kusmitsch da mesma maneira como reorganiza as narrativas históricas que extrai de suas leituras. E, dessa forma, parece mais uma vez construir uma narrativa a título de exercício de escrita, utilizando outro foco narrativo, debruçando-se sobre outras experiências que não as suas próprias.

Tempo e espaço são igualmente fragmentários no livro: espaço interno e externo se altercalam, assim como tempo presente e tempo passado, sem ordem definida, à medida que o protagonista avança em suas elucubrações. Essas alternâncias perceptuais chamam a atenção do leitor já nas dez primeiras anotações do romance: na primeira, Malte anota observações e impressões de uma caminhada pela cidade; na segunda, descreve os barulhos que ouve do seu quarto; na terceira, fala sobre o silêncio. Já a quarta adentra o âmbito da interioridade do personagem, e traz uma reflexão sobre o olhar que continua na anotação seguinte, mesclandose a uma situação pela qual passara na cidade. Da sexta à nona anotações Malte faz considerações sobre a morte na cidade grande, narra uma extensa rememoração da morte do avô paterno e comenta que sente medo. Na décima anotação, surge o tema da escrita, relacionada a seu medo, que não é definido precisamente e que costuma ser lido pelos críticos como medo da morte. Surgem aqui também observações de Malte sobre as circunstâncias em que se encontra. Nas primeiras páginas do romance, o foco de Malte oscila entre experiências atuais, lembranças da infância, reflexão sobre suas capacidades perceptuais e sobre suas sensações. O leitor das Aufzeichnungen começa a perceber, nas primeiras páginas, que não

52 “Agora vejo tudo assim, mas daquela vez o que mais me impressionou foi ler como procuraram, o dia dos Três Reis.” (RILKE, 1979, p. 110). 
deve esperar um encadeamento linear. O livro se parece, antes, com um mosaico de fragmentos de naturezas diferentes: narrativo, descritivo, poético, monólogo interior, citação, entre outros. Assim, de início já é possível enumerar alguns dos temas postos em destaque: a cidade, o olhar, a morte, a memória, o medo e a escrita. Adiante, outros serão trazidos à tona pelo personagem, como a arte, o amor e a leitura, ampliando o raio do programa estético que vai sendo desenvolvido e aprofundado. Para a análise a tomar corpo aqui, interessa-nos investigar como, no decorrer das Aufzeichnungen, olhar e escrita se entrelaçam.

O próprio título do romance é incomum e pode dar pistas a respeito de sua natureza: não se trata dos diários, cartas, memórias, ou da história de Malte Laurids Brigge, mas sim de suas Aufzeichnungen. Tomar notas, fazer apontamentos, descrever e registrar algo para tornálo documentado são acepções possíveis do verbo aufzeichnen ${ }^{53}$, que dá origem ao substantivo Aufzeichnungen. Composto pelo verbo zeichnen (desenhar) e o prefixo auf, que também corresponde à preposição sobre, o verbo aufzeichnen contém a ideia de desenhar sobre algo (auf etwas zeichnen). Aufzeichnung, nome dado ao produto dessa ação, pode ser entendido como registro, documentação, algo sobre o qual se desenhou, ou ainda, algo sobre o qual outra coisa foi desenhada. O título do romance de Rilke contém essa dimensão de anotação feita com o intuito de documentar, fazer registro - sobre o qual estão traçadas as percepções particulares de Malte. O termo Aufzeichnungen se distingue de outros termos que indicam algo que é produto da escrita (por exemplo, Schriften ou Briefe) porque ele guarda a dimensão de processo, de algo como um recurso que é utilizado para chegar a um fim, mas não é o fim último. O nome completo do protagonista - a pessoa que escreve as anotações - está designado no título, mas é importante notar que em primeiro plano está o termo Aufzeichnungen, ou seja, o destaque não é dado ao seu autor, e sim ao fato de que se trata de escritos, que são parte de um processo, que talvez nem tenha se completado.

Esse entendimento do título do livro de Rilke leva à proposta de leitura que será desenvolvida neste capítulo: a de que as Aufzeichnungen podem ser lidas como um conjunto de anotações do protagonista que registram um processo de aprendizado que o redefine como escritor. Ao longo desse processo, Malte descreve situações vistas na cidade, o próprio ato de

\footnotetext{
${ }^{53} \mathrm{O}$ Duden Universalwörterbuch define o termo aufzeichnen como "auf etwas zeichnen; erklärend hinzeichnen; zur Dokumentation schriftlich, auf Tonträger, Film oder Magnetband festhalten"; a do Wahrig Deutsches Wörterbuch lista também os sinônimos "aufschreiben, notieren, schriftlich niederlegen e aufnehmen". O Grimm Wörterbuch (Deutches Wörterbuch von Jacob Grimm und Wilhelm Grimm) indica como definição do verbo aufzeichnen o termo "designare" e "merkwürdige Begebenheiten aufzeichnen" e, de Aufzeichnung, os termos latinos "annotatio, designatio". Do latim, annotatio tem o sentido de escrever uma nota, fazer uma anotação, observação ou comentário, e designatio traz a acepção de fazer uma marcação, descrever ou designar, e também de desenhar (fonte: Perseus Digital Library, Tufts University).
} 
observar, suas memórias e suas novas percepções advindas do novo aprendizado do olhar. Assim, suas anotações adquirem o caráter de exercícios de escrita de Malte para apurar essas percepções, que por sua vez se tornam matéria fundamental da sua atividade e trabalho como poeta. Quando caminha pela cidade, a observação que faz de seu entorno não se resume ao momento em que essa atividade é posta em prática: tudo é anotado e transposto para o papel, e o que é visto é registrado de maneira indissociada do que é sentido, apreendido e compreendido por Malte. Olhar e escrita são exercitados pelo protagonistra através da composição de formas textuais descritivas e narrativas.

É necessário ressaltar ainda o fato de que o romance é dividido em duas partes. Rochelle Tobias afirma que Rilke pediu a seu editor que decidisse em que parte do livro deveria ser feita uma divisão. Tendo esse dado em mente, a estudiosa argumenta que, embora essa divisão possa parecer arbitrária, ela marca uma cisão entre as reflexões de ordem mais imediata, feitas a partir das vivências de Malte, de outras, orientadas por outros pontos de vista (cf. TOBIAS, 2013, p.667). Com efeito, na segunda parte do romace é possível notar algumas mudanças significativas no caráter das anotações. Tobias elenca algumas dessas mudanças. Enquanto a primeira parte do livro é dedicada ao aprendizado do olhar, a segunda é voltada ao aprendizado do amor; a primeira registra as andanças de Malte por Paris, a segunda se detém nas experiências de pessoas distantes dele, no tempo e no espaço, com as quais Malte teve contato através de suas leituras; uma foca nos esforços de Malte para conquistar autoridade enquanto escritor, a outra traz exemplos de autores e, principalmente, autoras, cuja autoridade é inquestionável (cf. TOBIAS, 2013, p. 667-668).

Além da figura de Malte, cuja subjetividade une as anotações, o único outro aspecto que se mantém constante ao longo de todo o livro é, provavelmente, a linguagem utilizada. Do início ao fim, Rilke emprega em seu romance uma prosa poética rica em associações imagéticas e sinestésicas, o que faz com que os textos pareçam estar na fronteira entre a prosa e a poesia. Exemplos não faltam: uma criança vista da rua respira, enquanto dorme, “[...]

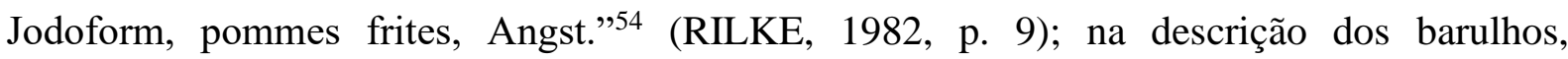
"Irgendwo klirrt eine Scheibe herunter, ich höre ihre großen Scherben lachen, die kleinen Splittern kirchern." ${ }^{55}$ (RILKE, 1982, p. 10); quando se vê enredado por uma multidão que festeja na rua, diz sobre os foliões que “[...] ihre Gesichter waren voll von dem Licht, das aus

\footnotetext{
54 “[...] iodofórmio, pommes frites, medo.” (RILKE, 1979, p. 5).

55 "Uma vidraça parte-se em algum lugar, tilintando, ouço os grandes cacos de vidro dando risadas, os menores dão risadinhas." (RILKE, 1979, p. 6).
} 
den Schaubuden kam, und das Lachen quoll aus ihren Munden wie Eiter aus offenen Stellen." 56 (RILKE, 1982, p. 43) e, ao assistir a um último procedimento médico no corpo morto do pai: "Er zog das Instrument vorsichtig zurück, und es war etwas wie ein Mund da, aus dem zweimal hintereinander Blut austrat, als sagte er etwas Zweisilbiges." ${ }^{57}$ RILKE, 1982, p. 127). Repetições também são frequentes, seja de palavras, expressões, frases inteiras ou apenas um fonema, criando sonoridades múltiplas no texto: "Vielleicht brach ein Gefäß in ihm, vielleicht trat ein Gift, das er lange gefürchtet hatte, gerade jetzt in seine Herzkammer ein, vielleicht ging ein großes Geschwür auf seinem Gehirn wie eine Sonne, die ihm die Welt verwandelte." ${ }^{58}$ (RILKE, 1982, p. 45). O uso abundante de imagens e a atenção à sonoridade contribuem para criar o caráter multifacetado do texto, adensando a narrativa, realçando suas qualidades poéticas e aumentando as possibilidades interpretativas.

\subsection{Olhar, experiência, memória e escrita}

As anotações de Malte sobre os temas mais variados são amarradas por questõeschave que motivam a escrita do protagonista: olhar, escrita, experiência e memória. É em torno desses quatro pontos que nossa análise será organizada. Em Die Aufzeichnungen, o aprendizado do olhar estrutura a narrativa. A partir dele, Malte desenvolve e aprofunda suas reflexões sobre a cidade, passado, presente, morte, escrita, medo, transformação, experiências, memórias, infância, amor. Logo no início do romance, Malte anuncia de forma programática sua entrega ao aprendizado do olhar: "Ich lerne sehen. Ich weiß nicht, woran es liegt, es geht alles tiefer in mich ein und bleibt nicht an der Stelle stehen, wo es sonst immer zu Ende war. Ich habe ein Inneres, von dem ich nicht wußte. Alles geht jetzt dorthin. Ich weiß nicht, was dort geschieht." ${ }^{, 59}$ (RILKE, 1982, p. 10). Há aqui uma dupla constatação do protagonista: a de

\footnotetext{
56 "Os rostos plenos da luz emanada das vitrinas, o riso transbordante das bocas como pus de feridas abertas." (RILKE, 1979, p. 30).

57 "Retirou o instrumento cautelosamente, e apareceu algo como uma boca da qual brotou sangue duas vezes, como se ela pronunciasse duas sílabas." (RILKE, 1979, p. 92).

58 "Talvez se rompesse dentro dele algum frasco, talvez um veneno há muito receado estivesse agora penetrando seu coração, talvez uma grande ferida se abrisse no seu cérebro como um sol que lhe transformasse o mundo." (RILKE, 1979, p. 32).

59 “Estou aprendendo a ver. Não sei o que provoca isso, tudo penetra mais fundo em mim, e não para no lugar em que costumava terminar antes. Tenho um interior que ignorava. Agora tudo vai dar aí. E não sei o que aí acontece." (RILKE, 1979, p. 6).
} 
que aprende a ver e, decorrente da primeira, de que possui uma interioridade até então desconhecida para ele mesmo, avistada pela primeira vez. Aprendendo a ver, Malte nota a extensão de sua própria interioridade, e deverá servir-se desse aprendizado - ou talvez exercitar esse aprendizado - investigando-a. August Stahl assinala o caráter programático da afirmação "Ich lerne sehen.", considerando que, na época da escrita do romance, Rilke passava a entender a visão (sehen) como pré-requisito fundamental para o trabalho artístico (cf. STAHL, 1996, p. 912). Stahl postula que o aprendizado do olhar é o aprendizado da objetividade: "Mit 'sehen' bezeichnete er [Rilke] eine Haltung, die durch Verzicht auf das subjektive Element sich ganz dem Objektiven des Außen zuwendet." ${ }^{\text {"O }}$ (STAHL, 1996, p. 912). Saber ver significaria, assim, olhar da maneira mais objetiva possível, permitindo que a própria subjetividade interfira o mínimo possível no entendimento do mundo que venha a decorrer da observação.

A oposição entre objetivo e subjetivo que está implícita no tema do aprendizado do olhar provoca um conflito interno no romance. A objetividade demandaria uma imparcialidade, um distanciamento e, ao mesmo tempo, uma abordagem direta. Malte afirma que está aprendendo a ver, o que significa que ele estaria aprendendo a deixar seus sentimentos e desejos de lado e desenvolvendo essa abordagem objetiva. E, no entanto, sua subjetividade aparece aflorada a todo momento nas situações narradas nas anotações. Essa contradição traz à luz uma tensão inerente ao processo de aprendizado de Malte, que será examinada ao longo desta pesquisa: seria possível atingir a máxima potencialidade da visão? Ao longo do romance, o exercício do olhar se desdobra de diversas maneiras: ele serve, a princípio, para Malte conhecer a cidade em que se encontra, parte de um mundo completamente diferente daquele que conhecia em sua terra natal; para investigar sua própria interioridade, que ele até então desconhecia; para reconhecer a si mesmo em relação às mudanças que percebe entre o tempo de sua infância e o tempo atual; e saber qual é seu lugar na metrópole moderna. Mas, mais importante, para que possa apreender e reter esses elementos e aproveitá-los como material para sua escrita. Saber ver é um modo de construir experiência, que é necessária para a escrita: saber ver está, portanto, relacionado diretamente a saber escrever.

A escrita está anunciada no título do romance e, além disso, os acontecimentos que sucedem no livro não são narrados no momento em que se passam, eles são todos narrados $a$ posteriori por Malte. Dessa forma, o ato de escrever torna-se a ação central do romance, e o

60 “Com 'ver', ele [Rilke] designa uma atitude que, através da renúncia ao elemento subjetivo, volta-se totalmente para a objetividade do exterior." (Tradução nossa). 
que o leitor tem nas mãos são os produtos dessa ação do protagonista. Ortrud Gutjahr afirma que "Die Aufzeichnungen [...] finden ihre Zentralperspektive in der Selbstreflexion der Erzählerfigur und damit in einem Erzählen über das Erzählen."61 (GUTJAHR, 1993, p. 370, grifo nosso). Malte escreve para registrar e elaborar o que fez ou viu e, à medida que faz esses relatos, reflete sobre seus textos e o que o motiva a escrever. A relação entre o aprendizado do olhar e a atividade da escrita se torna mais distinta na décima quarta anotação do livro: "Ich glaube, ich müßte anfangen, etwas zu arbeiten, jetzt, da ich sehen lerne."62 (RILKE, 1982, p. 21). Logo se torna claro que "trabalhar" quer dizer "escrever". Malte passa a revisar criticamente os escritos que havia produzido anteriormente, antes de começar a aprender a ver. "Wiederholen wir: ich habe eine Studie über Carpaccio geschrieben, die schlecht ist, ein Drama, das 'Ehe' heißt und etwas Falsches mit zweideutigen Mitteln beweisen will, und Verse. Ach, aber mit Versen ist so wenig getan, wenn man sie früh schreibt." ${ }^{\text {"63 }}$ (RILKE, 1982, p. 21). Porque ainda não sabia ver, Malte havia recorrido a artifícios comuns, como o do "terceiro", ou narrador onisciente, em terceira pessoa. Malte protesta contra o uso desse recurso. Uma vez que a onisciência é impossível, essa figura só pode ser construída artificialmente, e por isso é falsa, não se sustenta, não expressa a realidade de maneira verdadeira $^{64}$ (cf. RILKE, 1982, p. 22).

Essa passagem também possui caráter programático: nela Malte define sua visão do trabalho poético e estabelece qual é sua tarefa dali em diante: "Denn Verse sind nicht, wie die Leute meinen, Gefühle (die hat man früh genug), - es sind Erfahrungen."65 (RILKE, 1982, p. 21). É o novo aprendizado do olhar que desencadeia essas reflexões em Malte: se o novo olhar aprendido em Paris significa ver objetivamente, evitando que a subjetividade influencie suas impressões, está posto aqui que os sentimentos (Gefühle) podem nublar o conhecimento de mundo do sujeito, e uma poesia que se baseie neles diz menos sobre o mundo do que sobre

\footnotetext{
61 "As Aufzeichnungen [...] encontram sua perspectiva central na autorreflexão do narrador e, com isso, em uma narrativa sobre a narrativa." (Tradução nossa).

62 "Acho que eu deveria começar a fazer algo, a trabalhar, agora que estou aprendendo a ver." (RILKE, 1979, p. 14).

63 "Vamos recordar: escrevi um ensaio sobre Carpaccio, que é ruim, um drama chamado $O$ Casamento, que pretende provar algo falso com meios ambíguos, e versos. Ah, mas versos significam muito pouco se escritos cedo." (RILKE, 1979, p. 14).

${ }^{64} \mathrm{E}$, no entanto, as Aufzeichnungen possuem diversas passagens que Malte escreve como narrador onisciente, como foi apontado no início do capítulo.

65 "Pois versos não são, como as pessoas imaginam, sentimentos (a esses, temos cedo demais) - são experiências." (RILKE, 1979, p. 14).
} 
o sujeito. A preferência pela experiência (Erfahrung) no lugar do sentimento fica mais clara depois que Malte enumera exemplos de experiências que se deve ter antes de escrever versos: “[...] muß man viele Städte sehen, Menschen und Dinge, man muß die Tiere kennen, man muß fühlen, wie die Vogel fliegen, und die Gebärde wissen, mit welcher die kleinen Blumen sich auftun am Morgen."66 (RILKE, 1982, p. 21). A lista é longa, mas nessas poucas linhas já é possível perceber que boa parte do que Malte aponta como experiências do poeta são na verdade externas a ele - elas são vivenciadas por outras pessoas ou animais - é pela visão que ele as acessa. No mesmo trecho, ele afirma que não basta ter lembranças dos acontecimentos vistos:

Denn die Erinnerungen selbst sind es noch nicht. Erst wenn sie Blut werden in uns, Blick und Gebärde, namenlos und nicht mehr zu unterscheiden von uns selbst, erst dann kann es geschehen, daß in einer sehr seltenen Stunde das erste Wort eines Verses aufsteht in ihrer Mitte und aus ihnen ausgeht. ${ }^{67}$ (RILKE, 1982, p. 22, grifo do autor).

O que Malte propõe aqui é a busca de uma “objetividade" tão grande que o poeta se tornaria os momentos, pessoas e lugares que viu: as memórias do que foi visto tomariam o lugar de sua própria subjetividade, tornando-se ele mesmo anônimo (namenlos). Ou seja: Malte considera que há uma potência poética no anonimato.

Ainda que Malte esteja se referindo à lírica e não às formas narrativas em prosa, chama a atenção que o elemento posto como central para a escrita seja a experiência vivida (Erfahrung). Walter Benjamin argumenta que a experiência é a fonte da verdadeira arte de narrar e acusa o declínio desta no início do século XX, na Europa, devido à perda de experiências que pudessem ser transmitidas de pessoa para pessoa (cf. BENJAMIN, 2008, p. 197-198). Embora Benjamin se refira mais especificamente à perda da possibilidade de narrar a experiência da I Guerra, evento posterior à escrita das Aufzeichnungen, ele ressalta que o declínio da narrativa teve início muito antes, com a Idade Moderna, o estabelecimento da ordem capitalista e o surgimento do romance (cf. BENJAMIN, 2008, p. 201). Ora, Malte é um sujeito que cresceu em uma organização social antiga e mudou-se para Paris, a metrópole moderna por excelência, cuja configuração não propicia em nenhuma instância experiências

\footnotetext{
66 “"...] é preciso ver muitas cidades, pessoas e coisas, é preciso conhecer bichos, é preciso sentir como voam os pássaros, e saber com que gestos flores diminutas se abrem ao amanhecer.” (RILKE, 1979, p. 14).

67 "Pois as lembranças em si ainda não o são. Só quando se tornarem sangue em nós, olhar e gesto, sem nome, não mais distinguíveis de nós mesmos, só então pode acontecer que numa hora muito rara se erga do meio delas a primeira palavra de um poema." (RILKE, 1979, p. 15).
} 
significativas $^{68}$ a seus habitantes. A dificuldade (se não impossibilidade) de ter experiências significativas na cidade grande é pressentida por Malte logo de início: "So, also hierher kommen die Leute, um zu leben, ich würde eher meinen, es stürbe sich hier."69 (RILKE, 1982, p. 9). Não são elementos da aclamada efervescência social de Paris que capturam sua atenção, e sim de degradação e morte. Em sua lista de exemplos de experiências que um poeta deveria ter para escrever, Malte fala de sentar-se ao lado de um moribundo em um quarto e acompanhar mulheres grávidas e parturientes (cf. RILKE, 1982, p. 21), mas nenhuma dessas experiências é acessível a ele. A ele, é dado observar uma mulher grávida escorar-se em um muro próximo ao hospital onde ela será atendida por médicos, a ele é dado ver um homem cair na calçada e ser assistido por transeuntes que são completos estranhos (cf. RILKE, 1982, p. 9).

Entretanto, não é simplesmente a visão da morte que incomoda Malte, é a percepção de que tampouco a morte na cidade grande é a mesma de sua terra natal. Em Paris, as pessoas morrem mortes anônimas, impessoais, mortes que não são próprias, não lhes pertencem. "Wenn ich nach Hause denke, wo nun niemand mehr ist, dann glaube ich, das muß früher anders gewesen sein. Früher wußte man (oder vielleicht man ahnte es), daß man den Tod in sich hatte wie die Frucht den Kern."70 (RILKE, 1982, p. 14, grifo do autor). Enquanto no tempo de seus antepassados a morte era entendida como parte inseparável da vida desde o nascimento, na cidade moderna ela é tratada como um acontecimento, o último, o que finda a vida. Benjamin argumenta que essa mudança é uma das responsáveis pelo declínio da narrativa, uma vez que a morte passou a perder gradativamente, “[...] na consciência coletiva, sua onipresença e sua força de evocação.” (BENJAMIN, 2008, p. 207). A narrativa, segundo Benjamin, contém uma sabedoria advinda da experiência que é passada de geração a geração. A alienação em relação à morte é problemática porque "[...] é no momento da morte que o saber e a sabedoria do homem e sobretudo sua existência vivida - e é dessa substância que são

\footnotetext{
68 “[...] nós hoje sabemos que, para a destruição da experiência, uma catástrofe não é de modo algum necessária, e que a pacífica existência cotidiana em uma grande cidade é, para esse fim, perfeitamente suficiente. Pois o dia a dia do homem contemporâneo não contém quase nada que seja ainda traduzível em experiência [...]. O homem moderno volta para casa à noitinha extenuado por uma mixórdia de eventos - divertidos ou maçantes, banais ou insólitos, agradáveis ou atrozes -, entretanto nenhum deles se tornou experiência." (AGAMBEN, 2014, p. 2122).

69 "Então é aqui que as pessoas vêm viver; eu antes diria que aqui se vem morrer." (RILKE, 1979, p. 5).

70 "Quando penso em nossa casa, onde não mora mais ninguém, acho que outrora deve ter sido diferente. Antigamente sabíamos (ou talvez pressentíssemos) que contínhamos a morte em nós, como a fruta contém sua semente.” (RILKE, 1979, p. 9).
} 
feitas as histórias - assumem pela primeira vez uma forma transmissível." (BENJAMIN, 2008, p. 207).

Malte identifica em sua própria vida o declínio dessa transmissão da experiência: " $\mathrm{Da}$ man erzählte, wirklich erzählte, das muß vor meiner Zeit gewesen sein. Ich habe nie jemanden erzählen hören."71 (RILKE, 1982, p. 118). Quando Abelone tenta contar sobre a juventude da mãe de Malte, ele percebe "[...] daß sie nicht erzählen könne."72 (RILKE, 1982, p. 118). Não obstante, a tentativa da narrativa perdura de alguma forma em sua família: na anotação 44, Malte narra um episódio contado a ele por Abelone, sobre o período em que ela auxiliava seu pai, o conde Brahe, a redigir suas memórias. O conde ditava o texto para que a filha o escrevesse, e com frequência se frustrava e perdia a paciência com Abelone. Em um momento em que ele ditava a história de quando havia conhecido o Marquis de Belmare, o fato de Abelone não compreender uma palavra desencadeia a fúria do conde: "Sie kann es nicht schreiben', sagte er scharf, 'und andere werden es nicht lesen können. Und werden sie es überhaupt sehen, was ich da sage?",73 (RILKE, 1982, p. 121, grifo do autor). Sua intenção era traduzir em palavras sua própria experiência de ter olhado o Marquis de Belmare nos olhos, experiência que havia ficado inscrita em sua memória e, ainda assim, tinha dificuldade de narrá-la. “'Die Bücher sind leer”, grita o conde para Abelone,

[...] das Blut, darauf kommt es an, da muß man drin lesen können. Er hatte wunderliche Geschichten drin und merkwürdige Abbildungen, diese Belmare; er konnte aufschlagen, wo er wollte, da war immer was beschrieben; keine Seite in seinem Blut war überschlagen worden. ${ }^{74}$ (RILKE, 1982, p. 122).

Segundo o conde Brahe, Belmare havia tido inúmeras experiências em seu tempo, que transmitia facilmente; o conde, por sua vez, via-se limitado, insatisfeito e desiludido com a alternativa do livro de memórias - incapaz de narrar a impressão causada pelo olhar do marquês.

A perda das posses materiais da família de Malte é um sintoma de um processo mais amplo, de transformação da ordem social. Outro sintoma é a perda da experiência e da

\footnotetext{
71 “Contarem histórias, mas de verdade, isso deve ter sido antes do meu tempo.” (RILKE, 1979, p. 85).

72 “[...] que ela não sabia contar.” (RILKE, 1979, p. 85).

73 “-Ela não sabe escrever - disse asperamente - e outros não o saberão ler. E, afinal, será que irão ver o que estou dizendo aí?" (RILKE, 1979, p. 87).

74 “- Os livros são coisas vazias [...] o sangue, o sangue é que importa, é nele que se tem de poder ler. Ele tinha histórias estranhas no sangue, e imagens singulares, esse Belmare; podia abrir na página que quisesse, sempre havia algo descrito; nenhuma página fora omitida em seu sangue.” (RILKE, 1979, p. 88).
} 
possibilidade de narrar, diagnosticada por Walter Benjamin. Para Malte, esse processo se encerra definitivamente com a morte de seu pai. De sua mãe, ele escutava histórias sobre sua falecida tia, Ingeborg. Em alguns momentos, as descrições tinham tanta vivacidade que Malte parecia ver a tia renascer no rosto da mãe (cf. RILKE, 1982, p. 72); em outros, sua mãe insistia que havia visto determinada cena, como uma espécie de juramento de que sua narrativa não era uma invenção: “'Ich habe es gesehen, Malte', beschwor sie, 'Ich habe es gesehen." ${ }^{\prime 75}$ (RILKE, 1982, p. 71). Em relação a seu pai ocorre de modo diverso. Seu pai morre em um quarto alugado na cidade, quando a casa da família não mais existe e Malte se encontra no estrangeiro. Ele morre uma morte impessoal como as que Malte observa em Paris, e tudo o que deixa ao filho são velhos papéis pessoais. Malte os queima com desconfiança e desconforto, relutando em identificar-se com seus conteúdos, em admitir que esses resquícios do pai pudessem despertar lembranças em si mesmo. Isso até encontrar uma anotação manuscrita, um relato da morte do rei Christian IV (cf. RILKE, 1982, p. 124-130). Com ela, Malte constata o medo da morte de seu pai - um medo que também ele sentiu - e que deve ter-lhe provocado bastante sofrimento em seus últimos momentos, "So hatte man mir erzählt." ${ }^{, 76}$ (RILKE, 1982, p. 130).

Com a morte do pai, desaparece para Malte o último traço do mundo em que ele havia crescido, no qual era nobre e herdeiro de terras: “Heute Brigge und nimmermehr', sagte etwas in mir."77 (RILKE, 1982, p. 128). Malte vive agora em Paris, onde é pobre, sozinho, sem relações estreitas com ninguém, mais um desconhecido anônimo em meio a tantos outros. No início das Aufzeichnungen, Malte lamentava não poder tornar-se o poeta que gostaria de ser, semelhante àquele que lia na Biblioteca Nacional:

Gerade der Dichter ist es, der ich hätte werden wollen; denn er weiß von den Mädchen so viel, und ich hätte auch viel von ihnen gewußt. Er weiß von Mädchen, die vor hundert Jahren gelebt haben; es tut nichts mehr, daß sie tot sind, denn er weiß alles. Und das ist die Hauptsache. ${ }^{78}$ (RILKE, 1982, p. 38).

Esse poeta não vivia em Paris, mas no campo, como Malte teria escolhido viver se fosse possível. Ortrud Gutjahr ressalta que a forma de vida desse poeta imaginário está relacionada

\footnotetext{
75 ““Malte, eu vi', jurava: 'Eu vi.”” (RILKE, 1979, p. 51).

76 "Era o que me tinham contado." (RILKE, 1979, p. 94).

77 ““Hoje Brigge e nunca mais Brigge’, disse algo em mim.” (RILKE, 1979, p. 92).

78 "Esse é exatamente o poeta que eu desejaria ter sido; pois que ele sabe muitas coisas sobre donzelas que viveram há cem anos; e não faz mal que estejam mortas, pois que ele sabe tudo. E isso é o essencial." (RILKE, 1979, p. 27).
} 
ao mundo da infância de Malte: "Diese künstlerische Existenzform aber gehört der Vergangenheit als einer für immer verlorenen Zeit an."79 (GURJAHR, 1993, p. 381). O passado perdido da infância de Malte é o tempo da transmissão de sabedoria pela narrativa. Pode-se depreender que seria daí que viria o conhecimento do poeta idealizado por Malte, pois ele diz que, fosse essa sua vida, "Ich hätte viel geschrieben, denn ich hätte viele Gedanken gehabt, und Erinnerungen von Vielen." ${ }^{80}$ (RILKE, 1982, p. 39). Se vivesse em uma comunidade na qual houvesse a possibilidade de ter experiências narráveis, ele estaria inserido em uma sequência geracional de transmissão de sabedoria.

A biblioteca surge como um substituto ou uma alternativa a esse processo de transmissão, na qual os livros tomam o lugar que seria da fala, e nela Malte encontra um pouco da sabedoria que busca:

\begin{abstract}
Und ich sitze und habe einen Dichter. Was für ein Schicksal. Es sind jetzt vielleicht dreihundert Leute im Saale, die lesen; aber es ist unmöglich, daß sie jeder einzelne einen Dichter haben. (Weiß Gott, was sie haben.) Dreihundert Dichter giebt es nicht. Aber sieh nur, was für ein Schicksal, ich, vielleicht der armsäligste von diesen Lesenden, ein Ausländer: ich habe einen Dichter. ${ }^{81}$ (RILKE, 1982, p. 35).
\end{abstract}

Se a base da poesia é a experiência e Malte é um poeta em formação, esta é sua sorte: poder acessar a experiência do poeta através do livro. E para ele, as demais pessoas no salão da biblioteca não parecem ser tão diferentes dos transeuntes nas ruas. Lá Malte pode fugir das tentativas de contato dos pobres da cidade, e à sua volta todos leem, por certo. Mas não é possível saber se cada uma delas também tem um poeta consigo: não se pode saber se elas têm alguma fonte de quem receber um pouco da sabedoria da experiência, pois não há tantos poetas. Não se pode sequer saber se elas mesmas têm ideia do que pode um poeta oferecer: "Ihr wißt nicht, was das ist, ein Dichter? - Verlaine... Nichts? Keine Erinnerung? Nein."82 (RILKE, 1982, p. 38). A impossibilidade da Modernidade em proporcionar experiências significativas que possam ser transmitidas se estende: os poetas foram esquecidos - não se tem deles nenhuma lembrança (Erinnerung), de acordo com Malte.

\footnotetext{
79 "Essa forma de existência artística, porém, pertence ao passado como a algo para sempre perdido no tempo." (Tradução nossa).

80 “Teria escrito muito, pois teria muitos pensamentos e lembrança de muitas coisas." (RILKE, 1979, p. 27).

81 "Estou aqui sentado, e tenho um poeta. Que destino! Talvez haja trezentas pessoas lendo agora na sala; mas é impossível que cada uma tenha um poeta. (Sabe Deus o que têm!) Não existem trezentos poetas. Mas vejam só que destino: eu, talvez o mais pobre desses leitores, um estrangeiro, tenho um poeta." (RILKE, 1979, p. 24-25).

82 “Não sabem o que é isso, um poeta? Verlaine... Não? Nenhuma ideia? Não.” (RILKE, 1979, p. 26).
} 
A memória é outro elemento cuja importância é reafirmada a todo momento. $\mathrm{Na}$ décima anotação, Malte pensa sobre o que sua família perdeu na Dinamarca, e sobre sua atual situação. Sua reflexão começa na primeira pessoa, e ele sutilmente passa para a terceira, como se falasse genericamente da condição do homem moderno - que é também a sua: "Hätte man doch wenigstens seine Erinnerungen. Aber wer hat die? Wäre die Kindheit da, sie ist wie vergraben. Vielleicht muß man alt sein, um an das alles heranreichen zu können. Ich denke es mir gut, alt zu sein." 83 (RILKE, 1982, p. 19). Mas, em seu caso, as lembranças da infância são especialmente importantes, pois estão ligadas a um tempo em que a experiência e a narrativa ainda eram possíveis. Entretanto, Ortrud Gutjahr aponta que Malte não tem como recuperar o passado através das memórias, apenas evocá-lo em suas narrativas (cf. GUTJAHR, 1993, p. 381). Segundo a estudiosa, as lembranças acabam por revelar uma construção do seu estado de consciência em sua situação atual (cf. GUTJAHR, 1993, p. 382). E, com efeito, a rememoração da infância intensifica seus medos já suscitados pela vida moderna.

Se a primeira parte do romance é dedicada, em grande medida, à angústia que Malte sente em Paris ao observar que o mundo está irremediavelmente mudado e ao constatar que ele precisa se adaptar a essas mudanças não só para sobreviver como também para escrever, na segunda parte essa angústia dá lugar a uma mudança de paradigma que só foi possível devido ao aprendizado do olhar descrito nas primeiras páginas. Com a morte de seu pai, surge a compreensão de que a linhagem da família e a organização social em que ela prosperou terminaram e que ele, Malte, havia se tornado parte de outro mundo, havia passado a atuar em outro contexto e, portanto, seu trabalho como poeta não deveria pautar-se pelo modelo de seus antepassados. Aquele era o momento de construir um novo modelo, que para Malte está baseado no aprendizado do olhar. O poeta precisa, individualmente, desenvolver seu próprio olhar para representar sua nova realidade de maneira objetiva, sem interferência de seus próprios sentimentos a respeito dela. Saber ver aparece como elemento chave para esse novo modelo: a experiência (Erfahrung) ganha outros contornos, torna-se, nas Aufzeichnungen, aquilo que Malte pode observar com atenção. Quando chegam dois médicos ao quarto de seu pai para perfurar o coração do defunto, Malte insiste em permanecer no quarto para ver o procedimento. Ele nunca havia visto alguém perfurar o peito de um corpo sem vida e, além disso, não via motivo para deixar de observar um novo acontecimento que se lhe apresentasse:

\footnotetext{
83 "Se ao menos se tivessem lembranças. Mas quem as tem? Se a infância estivesse aqui, mas está como que enterrada. Talvez seja preciso envelhecer para poder alcançar todas essas coisas. Acho que deve ser bom, envelhecer." (RILKE, 1979, p. 13)
} 
"Es schien mir in der Ordnung, eine so merkwürdige Erfahrung nicht abzulehnen, wo sie sich zwanglos und unbedingt einstellte." 84 (RILKE, 1982, p. 126). É preciso saber ver objetivamente, olhar para as coisas despido o máximo possível de pré-julgamentos ou de emoções que possam interferir na observação, para só então poder narrá-las:

Nein, nein, vorstellen kann man sich nichts auf der Welt, nicht das Geringste. Es ist alles aus so viel einzigen Einzelheiten zusammengesetz, die sich nicht absehen lassen. Im Einbilden geht man über sie weg und merkt nicht, daß sie fehlen, schnell wie man ist. Die Wirklichkeiten aber sind langsam und unbeschreiblich ausführlich. ${ }^{85}$ (RILKE, 1982, p. 126-127).

Há nessa passagem uma negação da imaginação como fonte de criação ("vorstellen kann man nichts"). A criatividade do artista, nesse sentido, serviria não para criar representações a partir de suas ideias sobre coisas já mais ou menos conhecidas, mas apenas para reunir elementos que possam ser anotados a partir da observação direta. O ideal do olhar objetivo traz a ideia de que seria possível representar algo de forma semelhante à realidade em seus mínimos detalhes, desde que o objeto a ser representado possa ser visto antes pelo artista.

O ideal do olhar objetivo não seria apenas um meio de captar detalhes, mas, principalmente, uma forma de aprender a ver o que está além da mera aparência. A anotação 22 traz a indicação de que se trata de um rascunho de uma carta (“Ein Briefentwurf'). Malte escreve dirigindo-se a um " $D u$ " que nunca é especificado: seu possível interlocutor permanece incógnito e, até onde o leitor das Aufzeichnungen pode perceber, poderia ser o próprio Malte. Nesse rascunho, o protagonista evoca o poema "Une charogne", de Baudelaire (e o Saint-Julien-1'Hospitalier de Flaubert):

Erinnerst Du Dich an Baudelaires unglaubliches Gedicht 'Une Charogne'? Es kann sein, daß ich es jetzt verstehe. Abgesehen von der letzten Strophe war er im Recht. Was sollte er tun, da ihm das widerfuhr? Es war seine Aufgabe, in diesem Schrecklichen, scheinbar nur Widerwärtigen das Seiende zu sehen, das unter allem Seienden gilt. Auswahl und Ablehnung giebt es nicht. ${ }^{86}$ (RILKE, 1982, p. 62).

\footnotetext{
84 "Parecia-me correto não recusar uma oportunidade tão rara, quando se apresentava espontânea e sem reservas.” (RILKE, 1979, p. 91).

85 “Não, não, não podemos imaginar coisa alguma neste mundo, nem a mais insignificante. Tudo se constitui de tantos detalhes isolados que nada podemos prever. E na imaginação sempre os saltamos sem perceber que estão faltando, tão apressados somos. Mas as realidades são lentas, e indescritivelmente minuciosas.” (RILKE, 1979, p. 91).

86 "Lembras-te daquele inacreditável poema de Baudelaire, "Une Charogne"? Talvez agora eu o entenda. Com exceção da última estrofe, ele estava certo. Que haveria ele de fazer, se aquilo lhe acontecia? Era tarefa dele ver, no meio daquelas coisas terríveis, entre aquelas coisas só aparentemente repulsivas, o que é, o que realmente conta entre tudo o que é. Não se permitem nem escolha nem rejeição.” (RILKE, 1979, p. 44).
} 
Nessa colocação, Malte deixa implícito que Baudelaire era um poeta que sabia ver. Não se trata aqui apenas de exemplificar que o artista deva voltar o olhar para todas as coisas, sem concessões. Uma vez que o poeta aprende a ver, passa a ser sua tarefa ("seine Aufgabe") notar o que está além da aparência das coisas, ou seja, o cerne da existência, que seria, de acordo com Malte, compartilhada por todos os seres ("das Seiende zu sehen, das unter allem Seienden gilt"). Segundo Gutjahr, "Das Geschaute wird dem Ich zur Chiffre eines unsichtbaren Inneren." ${ }^{87}$ (GUTJAHR, 1993, p. 372), ou seja, do mesmo modo como, com o aprendizado da visão, Malte passa a reconhecer sua própria interioridade - "Ich habe ein Inneres, von dem ich nicht wußte." ${ }^{\prime 8}$ (RILKE, 1982, p. 10) -, ele passaria também a reconhecer em outros seres a interioridade oculta pelas aparências. A vida - o elemento existencial - está nos hospitais e sanatórios, nos transeuntes que caminham freneticamente de um lado para o outro, nos bulevares e nas vitrines das lojas. Está igualmente na carniça putrefata no meio da rua, e é preciso olhar também para ela, escrever sobre ela.

A propósito do processo da perda da experiência narrável na Modernidade, Agamben afirma que "observando bem, a poesia moderna - de Baudelaire em diante - não se funda em uma nova experiência, mas em uma ausência de experiência sem precedentes." (AGAMBEN, 2014, p. 51). As experiências necessárias para escrever bons versos, elencadas por Malte na décima quarta anotação, não são mais possíveis, agora que ele vive sozinho na metrópole moderna. Nela, ele pode apenas ver situações, pessoas, objetos, com algum distanciamento que só tende a aumentar à medida que ele exercita a objetividade do olhar. Ver, portanto, não é experienciar: em Paris, as únicas experiências que Malte pode de fato ter são a experiência da visão e a da escrita. Com a alusão a Baudelaire, Malte parece procurar aproximar-se a um poeta que lidou com uma situação semelhante àquela em que ele se encontra. Em "Une charogne", Baudelaire descreve em detalhes uma carcaça e como ela está em relação ao ambiente, de forma que toda sua materialidade está presente no poema: a posição do corpo, o calor do sol fazendo exalar seu cheiro, as moscas que a sobrevoam, as larvas que comem sua carne, o líquido que escorre na rua ${ }^{89}$. O leitor pode praticamente vê-la diante de si, como o

\footnotetext{
87 “O que é visto se torna o eu encodificado em uma interioridade invisível.” (Tradução nossa).

88 “Tenho um interior que ignorava." (RILKE, 1979, p. 6).

${ }^{89}$ Eis o trecho especialmente descritivo da carniça: "Rappelez-vous l'objet que nous vimes, mon âme, / Ce beau matin d'été si doux: / Au détour d'un sentier une charogne infâme / Sur un lit semé de cailloux, // Les jambes en l'air, comme une femme lubrique, / Brûlante et suant les poisons, / Ouvrait d'une façon nonchalante et cynique / Son ventre plein d'exhalaisons. // Le soleil rayonnait sur cette pourriture, / Comme afin de la cuire à point, / Et de rendre au centuple à la grande Nature / Tout ce qu'ensemble ele avait joint; // Et le ciel regardait la carcasse superbe / Comme une fleur s'épanouir. / La puanteur était si forte, que sur l'herbe / Vous crûtes vous évanouir. //
} 
poeta a deve ter olhado com atenção. Em seguida, ele lembra a sua companheira de que, não importa a beleza que tenha, o seu destino, como o de todas as pessoas, é o mesmo dessa carcaça abjeta.

A descrição da visão da carniça no poema de Baudelaire provoca um choque no leitor e descreve um choque na personagem da amante do eu-lírico, que desmaia sobre a grama. Segundo Agamben, Baudelaire coloca "o $\operatorname{choc}^{90}$ no cerne do próprio trabalho artístico" (AGAMBEM, 2014, p. 52). E explicita que, enquanto a experiência adquirida no cotidiano protegia as pessoas de surpresas, o sujeito da poesia de Baudelaire, privado da experiência, encontra-se completamente exposto aos choques. A vivência de Malte em Paris, em toda a primeira parte do romance, é de choque ${ }^{91}$ : desde as primeiras anotações, quando afirma que tudo o que vê o remete à morte, e não à vida, e quando enumera os ruídos e os cheiros. Parte do choque sentido por ele na cidade está nos seus encontros fortuitos com pessoas pobres que vagam pelas ruas. Em Paris, Malte também é pobre e passa muito tempo vagando pela cidade; ele tem poucos pertences, nenhuma relação estreita com outras pessoas e suas roupas são gastas. Ele encarna a figura do poeta solitário, empobrecido, alguém não adaptado e adequado às normas da sociedade. Essa caracterização se aproxima, de certa forma, à da figura do trapeiro, que, de acordo com Jeanne Marie Gagnebin (a partir de Walter Benjamin), corresponderia ao narrador da Modernidade. O trapeiro (ou Lumpensammler ou chiffonnier) é

Les mouches bourdonnaient sur ce ventre putride, / D'où sortaient de noirs bataillons / De larves, qui coulaient comme un épais liquide / Le long de ces vivants haillons." (BAUDELAIRE, 1972, p. 43-44). ["Recorda o objeto vil que vimos, numa quieta, / Linda manhã de doce estio: / Na curva de um caminho uma carniça abjeta / Sobre um leito pedrento e frio, // As pernas para o ar, como uma mulher lasciva, / Entre letais transpirações, / Abria de maneira lânguida e ostensiva / Seu ventre a estuar de exalações. // Reverberava o sol sobre aquela torpeza, / Para cozê-la a ponto, e para, / Centuplicado, devolver à Natureza / Tudo quanto ela ali juntara. // E o céu olhava do alto a soberba carcaça / Como uma flor se oferecer; / Tão forte era o fedor que sobre a relva crassa / Penaste até desfalecer. // Zumbiam moscas sobre esse pútrido ventre, / De onde em bandos negros e esquivos / Larvas se escoavam com um grosso líquido entre / Esses trapos de carne, vivos.” (ALMEIDA, 2010, p. 51).]

\footnotetext{
90 Agamben utiliza a palavra francesa "choc", mas o tradutor acrescenta em nota que ela tem no texto o mesmo sentido de choque, abalo. A citação completa auxilia a compreensão sobre a que Agamben se refere quando fala de choque: "É tendo como fundo esta crise da experiência que a poesia moderna encontra a sua situação própria. Pois, observando bem, a poesia moderna - de Baudelaire em diante - não se funda em uma nova experiência, mas em uma ausência de experiência sem precedentes. Daí a desenvoltura com a qual Baudelaire é capaz de colocar o choc no cerne do próprio trabalho artístico. A experiência é, de fato, voltada primeiramente à proteção contra as surpresas, e o produzir-se de um choque implica sempre em uma brecha na experiência. Fazer experiência significa: subtrair-lhe a sua novidade, neutralizar o seu poder de choque." (AGAMBEN, 2014, p. 5152).
}

91 "Die massenhafte Ansammlung von Menschen, die Häuserfluchten und die Künstlichkeit der öffentlichen Gärten, das Verkehrsaufkommen und die Hektik in Paris wurden von Rilke in der Weise erlebt, wie er es seinem Protagonisten Brigge eingeschrieben hat: als Schock." (GUTJAHR, 1993, p. 374). ["A multidão massiva de pessoas, as fileiras de casas e a artificialidade dos jardins públicos, o volume do tráfego e a agitação em Paris foram vivenciados por Rilke da maneira como ele a inscreveu em seu protagonista Brigge: como choque." (Tradução nossa).] 
“[...] esta personagem das grandes cidades modernas que recolhe os cacos, os restos, os detritos, movido pela pobreza, certamente, mas também pelo desejo de não deixar nada se perder [...]" (GAGNEBIN, 2014, p. 53-54). A figura do trapeiro aparece em alguns dos escritos de Baudelaire, como no poema "Le vin des chiffonniers", de Les fleurs du mal (1860), e Benjamin explora essa recorrência, aproximando a atividade do trapeiro à do poeta moderno. Este retiraria do lixo produzido pela sociedade o assunto de seus poemas; ambos são vistos como escória, não se adequam às exigências do mundo burguês e erram solitários pelas ruas recolhendo os rejeitos da cidade ${ }^{92}$. O poema "Une charogne", nesse sentido, pode ser tomado como um exemplo extremo de um tema que pertence à essa esfera do lixo da sociedade. Pode-se também traçar algumas relações entre Malte e o chiffonier para pensar a relação entre as Aufzeichnungen e a obra baudelairiana.

Na primeira parte do romance, há uma série de episódios marcados pela comparação entre o protagonista e outras pessoas que vagam pela metrópole. Nessas passagens, Malte passa a perceber-se e definir-se em contraposição a essas figuras. A primeira anotação em que Malte reflete sobre as demais pessoas pobres e narra seus incômodos encontros com elas é a anotação 16, que se passa na Biblioteca Nacional. Malte celebra o fato de poder estar no salão da biblioteca lendo um poeta, "Obwohl ich arm bin. Obwohl mein Anzug, den ich täglich trage, anfängt, gewisse Stellen zu bekommen, obwohl gegen meine Schuhe sich das und jenes einwenden ließe."93 (RILKE, 1982, p. 35). Mas apesar de gastas, suas roupas estão limpas, e apesar da aparência empobrecida, Malte mantém seus pulsos, mãos e unhas limpos, e por esse motivo, afirma, ele pode transitar por lugares vetados às pessoas pobres.

\begin{abstract}
Aber es giebt doch ein paar Existenzen, auf dem Boulevard Saint-Michel zum Beispiel und in der rue Racine, die lassen sich nicht irremachen, die pfeifen auf die Gelenke. Die sehen mich an und wissen es. Die wissen, daß ich eigentlich zu ihnen gehöre, daß ich nur ein bißchen Komödie spiele. ${ }^{94}$ (RILKE, 1982, p. 36).
\end{abstract}

\footnotetext{
92 “Trapeiro ou poeta - a escória diz respeito a ambos; solitários, ambos realizam seu negócio nas horas em que os burgueses se entregam ao sono; o próprio gesto é o mesmo em ambos. Nadar fala do andar abrupto de Baudelaire; é o passo do poeta que erra pela cidade à cata de rimas; deve ser também o passo do trapeiro que, a todo instante, se detém no caminho para recolher o lixo em que tropeça." (BENJAMIN, 2011, p. 78-79). Jeanne Marie Gagnebin reforça ainda que "Esse narrador sucateiro [...] não tem por alvo recolher os grandes feitos. Deve muito mais apanhar tudo aquilo que é deixado de lado como algo que não tem significação, algo que parece não ter importância nem sentido, algo com que a história oficial não sabe o que fazer." (GAGNEBIN, 2014, p. 54).

93 "Embora eu seja pobre. Embora o terno que uso diariamente comece a mostrar lugares rotos, e meus sapatos mereçam reparos.” (RILKE, 1979, p. 25).
}

94 "Mas há algumas criaturas, por exemplo no Boulevard Saint-Michel e na Rue Racine, que não se deixam enganar, e não dão nada por meus pulsos limpos. Encaram-me e sabem. Sabem que na verdade pertenço a eles, que estou apenas representando um pouco.” (RILKE, 1979, p. 25). 
Malte começa a descrever momentos em que pessoas pobres, por quem passa na rua, a seu ver demonstraram reconhecê-lo como um igual. Essas demonstrações são feitas principalmente, através de uma piscada irônica ou um olhar mais insistente, por vezes um gesto sutil que parece querer mostrar algo: o ponto chave é que Malte $v \hat{e}$ o olhar dos outros dirigido a ele, e isso o atordoa. Essa comunicação pelo olhar é algo que Malte não compreende, mas ao mesmo tempo, não consegue ignorar: "Wer sind diese Leute? Was wollen sie von mir? Warten sie auf mich? Woran erkennen sie mich?"95 (RILKE, 1982, p. 36). A recorrência desses acontecimentos o perturba e o leva a questionar se ele pertence a esse grupo. Em sua visão, a roupa puída ou a barba descuidada não são motivos suficientes para torná-lo semelhante a essas pessoas,

Denn das ist mir klar, daß das die Fortgeworfenen sind, nicht nur Bettler; nein, es sind eigentlich keine Bettler, man muß Unterschiede machen. Es sind Abfälle, Schalen von Menschen, die das Schicksal ausgespieen hat. Feucht vom Speichel des Schicksals kleben sie an einer Mauer, an eine Laterne, an einer Plakatsäule, oder sie rinnen langsam die Gasse herunter mit einer dunklen, schmutzigen Spur hinter sich her. ${ }^{96}$ (RILKE, 1982, p. 36-37).

Malte não está aqui apenas procurando diferenciar-se de pessoas pobres que parecem sinalizar a ele que são iguais: a maneira como ele descreve essas pessoas é carregada de uma violenta repulsa. Não parece ser a probreza em si que ele recusa, mas sim a possibilidade de identificar-se com uma situação irreversível de perda. A possibilidade de perda que o atormenta não é a das posses materiais (essas, ele já perdeu), mas, talvez, a da possibilidade de criar, de fazer seu trabalho e de que ele venha a ter alguma relevância.

Malte não quer ser identificado como um deles, e essas são pessoas que ele gostaria que não o olhassem e para as quais ele gostaria de não olhar. A biblioteca é um refúgio de seus olhares indesejados, e a marca maior e indiscutível, de sua diferenciação: Malte pode entrar nela e ler um poeta, porque, apesar de pobre, ele possui o cartão necessário para isso, enquanto aos demais pobres até a leitura é vetada (cf. RILKE, 1982, p. 38). Na segunda parte do romance, há duas menções às pessoas pobres da cidade que são dignas de nota, pois nelas Malte assume uma atitude menos defensiva e aterrorizada em relação a elas. Na anotação 59, ele descreve um vendedor de jornais, e admite que costumava passar por ele na rua e fingir

95 "Quem são essas pessoas? Que pretendem de mim? Estarão à minha espera? Como me reconhecem?" (RILKE, 1979, p. 25).

96 "Pois compreendi bem que esses são os marginalizados, não apenas os mendigos; não, na verdade não são mendigos, é preciso estabelecer diferenças. São lixo, cascas de homens que o destino cuspiu fora. Úmidos do cuspe do destino, grudam numa parede, num lampião de rua, num poste de cartaz, escorrem rua abaixo deixando um rastro escuro e sujo.” (RILKE, 1979, p. 25). 
que estava ocupado demais para notá-lo. E admite que, de fato, estava ocupado: "Ich war beschäftigt, ihn mir vorzustellen, ich unternahm die Arbeit, ihn einzubilden, und der Schweiß trat mir aus vor Anstrengung." 97 (RILKE, 1982, p. 164). Aqui novamente Malte estabelece uma contraposição entre imaginar e ver: enquanto acreditava saber como o homem era, sem tê-lo olhado de fato, Malte apenas construía uma imagem inventada de como ele era, uma imagem que, sem dúvida não correspondia à verdade: "Ich wußte sofort, daß meine Vorstellung wertlos war."98 (RILKE, 1982, p. 165). Na anotação 60, Malte nega que queira distinguir-se das demais pessoas pobres: seu argumento é que ele não teria a força e a coragem necessárias para viver como eles, e seria presunçoso se quisesse comparar-se a eles.

Mas a possibilidade de identificação de Malte com pessoas pobres ou desoladas na cidade não se limita apenas à limpeza das roupas ou ao fato de fazer todas as refeições. Ainda no início do livro, na anotação 18, Malte narra retrospectivamente uma série de situações vividas na cidade, sendo que a última delas havia sido especialmente perturbadora. Em casa, escreve: "Es ist gut, es laut zu sagen: 'Es ist nichts geschehen.' Noch einmal: 'Es ist nichts geschehen.' Hilft es?"'99 (RILKE, 1982, p. 40). Seu fogão havia fumaçado seu quarto, obrigando-o a sair; ele podia ter ido ao Louvre, mas deixou de ir para evitar os olhares dos pobres que iam lá para se aquecer: "Ich bin immer unterwegs gewesen."100 (RILKE, 1982, p. 40). Em sua infindável caminhada naquele dia, Malte viu um homem cego que empurrava um carrinho de legumes e gritava, apregoando seus produtos; passou por casas semi-demolidas, cujas paredes internas estavam agora à mostra, revelando marcas deixadas pelas vidas que ali habitaram; teve um encontro funesto em uma crémerie onde parou para comer e, sem conseguir comer, precipitou-se novamente para a rua, onde foi engolfado por uma multidão que comemorava o carnaval (cf. RILKE, 1982, p. 40-44). Todos esses encontros têm seu impacto, mas na crémerie Malte se identifica com um homem que lhe parece moribundo, e esse encontro se relaciona com as reflexões feitas na biblioteca.

Antes mesmo de olhar para o homem na crémerie, Malte diz que sente sua presença e ela o aterroriza: "Mit unbeschreiblicher Anstrengung zwang ich mich, nach ihm hinzusehen, denn ich hoffte noch, daß alles Einbildung sei. Aber es geschah, daß ich aufsprang und

\footnotetext{
97 "Estava ocupado imaginando aquele homem, executava a tarefa de configurá-lo, e transpirava com o esforço." (RILKE, 1979, p. 118).

98 "Logo entendi que minha fantasia não fora válida." (RILKE, 1979, p. 119).

99 “É bom dizer em voz alta: 'Nada aconteceu.' Mais uma vez: 'Nada aconteceu.' Isso ajuda?’ (RILKE, 1979, p. 28).
}

100 “Andei o tempo todo." (RILKE, 1979, p. 28). 
hinausstürzte; denn ich hatte mich nicht geirrt."101 (RILKE, 1982, p. 45-46). Estava ali sentado um homem que se desprendia do mundo e não oferecia mais resistência - um homem que estava a morrer, ou a se tornar, como os pobres que encaram Malte na rua, alguém cuspido pelo destino. Mas, ao contrário dos pobres mencionados antes, Malte se identifica com esse homem, se sente ligado a ele. A diferença é que, enquanto o moribundo na crémerie parece não mais resistir ao seu definhamento, ele afirma:

Und ich wehre mich noch. Ich wehre mich, obwohl ich weiß, daß mir das Herz schon heraushängt und daß ich doch nicht mehr leben kann, auch wenn meine Quäler jetzt von mir abließen. Ich sage mir: es ist nichts geschehen, und doch habe ich jenen Mann nur begreifen können, weil auch in mir etwas vor sich geht, das anfängt, mich von allem zu entfernen und abzutrennen. Wie graute mir immer, wenn ich von einem Sterbenden sagen hörte: er konnte schon niemanden mehr erkennen. Dann stellte ich mir ein einsames Gesicht vor, das sich aufhob aus Kissen und suchte, nach etwas Bekanntem suchte, nach etwas schon einmal Gesehenem suchte, aber es war nichts da. Wenn meine Furcht nicht so groß wäre, so würde ich mich damit trösten, daß es nicht unmöglich ist, alles anders zu sehen und doch zu leben. Aber ich fürchte mich, ich fürchte mich namenlos vor dieser Veränderung. Ich bin ja noch gar nicht in dieser Welt eingewöhnt gewesen, die mir gut schein. Was soll ich in einer anderen? Ich würde so gerne unter den Bedeutungen bleiben, die mir lieb geworden sind, und wenn schon etwas sich verändern muß, so möchte ich doch wenigstens unter den Hunden leben dürfen, die eine verwandte Welt haben und dieselben Dinge. ${ }^{102}$ (RILKE, 1982, p. 46-47, grifo nosso).

Compreender o medo ao qual Malte se refere ao longo da primeira parte das Aufzeichnungen como medo da morte parece, em vista dessa passagem, algo reducionista. Malte sente medo da transformação que está a operar em si mesmo agora que ele aprende a ver: o aprendizado do olhar é tratado aqui como algo que oferece um risco de morte, mesmo que ele tenha consciência de que é possível abandonar os sentidos prévios e continuar a viver. Se aprender a ver significa um processo de abdicar dos significados aprendidos durante toda a vida para conseguir olhar para o mundo com o olhar mais despido de ideias pré-concebidas, aprender a ver significa também, nesse sentido, afastar-se do mundo de algum modo, ou, antes, afastar-se das relações que impõem esses sentidos convencionalizados. Para Malte, esse afastamento

101 "Com indescritível esforço, obriguei-me a olhá-lo, pois ainda esperava que tudo fosse impressão minha. Acontece, porém, que me levantei de um salto e precipitei-me para fora; pois não me enganara [...]." (RILKE, 1979, p. 32).

102 "Mas eu ainda me defendo. Defendo-me, embora saiba que meu coração já está arrancado e que não posso mais viver, ainda que meus torturadores me abandonassem. Digo a mim mesmo: nada aconteceu, e, no entanto, só pude entender aquele homem porque também em mim algo está começando a me afastar e separar de todas as coisas. O quanto sempre me foi horrível ouvir dizer de algum moribundo: ele já não reconhece ninguém. Imaginava um rosto solitário soerguendo-se dos travesseiros à procura de algo conhecido, algo já visto uma vez, mas não havia coisa alguma. Se meu medo não fosse tão grande, eu me consolaria pensando não ser impossível ver tudo com um olhar diferente e, ainda assim, viver. Mas receio, receio indizivelmente essa mudança. Sequer me habituei a este mundo, que me parece bom. Que haverei de fazer em algum outro? Gostaria tanto de permanecer entre os significados que aprendi a amar, e, se alguma coisa tivesse de mudar, gostaria ao menos poder viver entre os cães, cujo mundo é aparentado com o meu." (RILKE, 1979, p. 32). 
pode implicar abdicar de modo definitivo, do tempo de seu passado, de sua infância e de sua família - uma morte simbólica de uma vida passada para começar uma nova, na qual tudo é novo e para a qual ele ainda não se sente apto.

O aprendizado do olhar atemoriza Malte. Em um primeiro momento, é possível depreender do texto que atingir a meta do olhar objetivo implicaria na dissolução de sua subjetividade:

\begin{abstract}
Noch eine Weile kann ich das alles aufschreiben und sagen. Aber es wird ein Tag kommen, da meine Hand weit von mir sein wird, und wenn ich sie schreiben heißen werde, wird sie Worte schreiben, die ich nicht meine. [...] Ich bin der Eindruck, der sich verwandeln wird. Oh, es fehlt nur ein kleines, und ich könnte das alles begreifen und gutheißen. Nur ein Schritt, und mein tiefes Elend würde Seligkeit sein. Aber ich kann diesen Schritt nicht tun, ich bin gefallen und kann mich nicht aufheben, weil ich zerbrochen bin. Ich habe ja immer noch geglaubt, es könnte eine Hülfe kommen. Da liegt es vor mir in meiner eigenen Schrift, was ich gebetet habe, Abend für Abend. Ich habe es mir aus den Büchern, in denen ich es fand, abgeschrieben, damit es mir ganz nahe wäre und aus meine Hand entsprungen wie Eigenes. Und ich will es jetzt noch einmal schreiben, hier vor meinem Tisch kniend will ich es schreiben; denn so habe ich es länger, als wenn ich es lese, und jedes Wort dauert an und hat Zeit zu verhallen. ${ }^{103}$ (RILKE, 1982, p. 47, grifo nosso).
\end{abstract}

O processo de aprender a ver objetivamente tem como consequência para Malte uma quebra da oposição entre sujeito e objeto. Saber olhar implica abrir os sentidos para o objeto e recusar o que a própria subjetividade entende dele e Malte, quando diz que está aprendendo a ver, diz também que possui uma interioridade que até então desconhecia, e que nela tudo entra (cf. RILKE, 1982, p. 10). Tudo o que Malte vê e vivencia se torna impressão (Eindruck) dentro dele, tal como a imagem da casa do seu avô, conde Brahe, lhe parece estar impressa tão intimamente, como se tivesse caído de uma altura imensa até a profundeza de seu ser, e com ela se misturado (cf. RILKE, 1982, p. 25). O entendimento de Fülleborn é "Dann aber wird deutlich, daß zwischen dem, was wir Subjekt und Objekt nennen, keine Grenzen bestehen, sondern daß ein weder in jenem noch in diesem gründender wechselseitiger Bezug, ein

\footnotetext{
103 "Por algum tempo ainda poderei escrever e dizer todas essas coisas. Mas virá um dia em que minha mão estará longe de mim, e, quando eu mandá-la escrever, escreverá palavras que não quero. [...] Eu sou a impressão que quer se transpor. Pouco bastaria, e eu poderia entender tudo e aquiescer a tudo. Um passo apenas, e minha profunda miséria se tornaria felicidade. Mas não posso dar esse passo, caí e não posso mais me levantar porque estou todo quebrado. Até agora acreditei que veria chegar algum auxílio. Eis aí, diante de mim, na minha própria letra, o que rezei noite após noite. Transcrevi-o dos livros em que o encontrava, para que estivesse bem perto, saindo de minha mão como se fosse meu. E vou copiá-lo agora ainda uma vez: ajoelhado aqui diante da minha mesa quero copiá-lo, pois assim o retenho em mim mais do que se apenas o lesse, e cada palavra adquire uma duração e ganha tempo de repercutir no ar.” (RILKE, 1979, p. 32-33).
} 
Austausch und eine Umschläglichkeit, herrscht." 104 (FÜLLEBORN, 2000, p. 338). Por esse viés, não haveria separação entre interior e exterior, objetivo e subjetivo, e não há um que prevaleça sobre o outro. Seria também por esse motivo que Malte diz reconhecer as casas parcialmente demolidas, cujo interior aparece completamente exposto (cf. RILKE, 1982, p. 43). Macleod afirma que há ainda uma sugestão de que os papéis de sujeito e objeto se invertem, como quando Malte encontra uma multidão no carnaval e não consegue distinguir se são as pessoas ou ele que estão se movendo (cf. MACLEOD, 1992, p. 412; RILKE, 1982, p. 44). As impressões das coisas que vê e vivencia se transformam dentro dele, se tornam, em certa medida, ele, Malte. Nesse sentido, porém, pode-se argumentar que o olhar objetivo não iria obliterar a subjetividade de Malte, mas sim misturar-se a ela, pois as impressões passam necessariamente pela subjetividade dele. Não é possível, assim, atingir a potencialidade absoluta da visão objetiva.

Ainda assim, ele reluta, pois tem medo da transformação que se opera nele. A ajuda de que Malte tanto precisa está em seus próprios escritos: o olhar objetivo é exercitado na escrita, noite após noite. Mais do que uma ajuda, Malte precisa aprender a ver para escrever no novo contexto em que vive. Ao final da anotação, ele copia o trecho final do poema em prosa "A une heure du matin”, de Baudelaire, e um citação do Livro de Jó (cf. STAHL, 1996, p. 930): dois textos cujos sujeitos estiveram apartados do mundo, seja por vontade própria, como o eu lírico de Baudelaire, ou pela crença em uma força maior, como Jó. Ele copia os trechos, sem inserir qualquer referência: como observa Rita Rios, ele os transcreve de próprio punho para que pareçam ser de sua autoria (cf. RIOS, 2011, p. 92). Malte parece prender-se a essas duas figuras como em busca de um modelo, um parâmetro mais próximo do que ele almeja para si mesmo, do que um simples moribundo em um café, como se ele estivesse se comparando a duas personagens que estiveram, em diferentes graus, submetidas a grandes provações, mas que resistiram, superaram seus sofrimentos e eventualmente encontraram alívio. Malte parece aferrar-se à ideia de que se ele for forte o bastante para enfrentar as dificuldades que seu novo contexto impõem a ele, ele será futuramente recompensado.

$\mathrm{Na}$ anotação 19, Malte narra sua ida ao hospital para uma consulta médica. Lá, encontra pessoas como as que o encaram nas ruas. Incomodado com a espera, as pessoas e o ar viciado, ele é mais uma vez confrontado pela possibilidade de que tenha sido tomado como uma das pessoas "cuspidas pelo destino", de quem tanto desejava diferenciar-se: "Es kam mir

104 "Então fica evidente que entre ambos, o que chamamos de sujeito e objeto, não há nenhuma fronteira, e que entre eles há uma conexão fundante e recíproca, na qual um não prevalece, nem substitui ou acoberta o outro." (Tradução nossa). 
in den Sinn, daß man mich hierher gewiesen hatte, unter diese Leute, in diese überfüllte, allgemeine Sprechstunde. Es war sozusagen die erste öffentliche Bestätigung, daß ich zu den Fortgeworfenen gehörte [...]."105 (RILKE, 1982, p. 49). Nos períodos de espera no hospital, Malte descreve as pessoas que também estão ali, e os corpos que retrata são encurvados, envelhecidos, manchados, deformados. A perturbação que ocorre no corredor de espera do hospital soma-se à do encontro com o moribundo na crémerie e, duas anotações adiante, a uma nova experiência nas ruas da cidade. Um dia em que se sentia mais disposto, Malte sai com a intenção de ir novamente à Biblioteca Nacional e, enquanto caminha pelos bulevares, nota os gestos de algumas pessoas que reparam e riem de um homem alto que andava à sua frente. Malte começa a notar que o homem faz repetidos movimentos involuntários com as pernas e as mãos enquanto caminha.

Mais uma vez, como no episódio da crémerie, Malte sente-se ligado ao homem, mas, ao invés de fugir como fez anteriormente, passa a segui-lo, registrando todos os seus movimentos e preocupando-se com os possíveis desdobramentos caso o homem perdesse totalmente o controle de seu corpo:

Ich konnte nichts dagegen tun, daß meine Angst dennoch wuchs. Ich wußte, daß, während er ging und mit unendlicher Anstrengung versuchte, gleichgültig und zerstreut auszusehen, das furchtbare Zucken in seinem Körper sich anhäufte; auch in mir war die Angst, mit der er es wachsen und wachsen fühlte, und ich sah, wie er sich an den Stock klammerte, wenn es innen in ihm zu rütteln begann. Dann war der Ausdruck dieser Hände so unerbittlich und streng, daß ich alle Hoffnung in seinen Willen setzte, der groß sein mußte. Aber was war da ein Wille. Der Augenblick mußte kommen, da seine Kraft zu Ende war, er konnte nicht weit sein. Und ich, der ich hinter ihm herging mit stark schlagendem Herzen, ich legte mein bißchen Kraft zusammen wie Geld, und indem ich auf seine Hände sah, bat ich ihn, er möchte nehmen, wenn er es brauchte. ${ }^{106}$ (RILKE, 1982, p. 60).

Malte o segue pela cidade até o momento em que o homem, sem conseguir mais conter a força de seus movimentos, cede a eles, contorcendo-se, e é engolido pela multidão que o cerca

105 “Ocorreu-me que me tinham mandado para ali, entre aquela gente, àquela hora de consulta pública, superlotada. Era, por assim dizer, a primeira confirmação oficial de que eu fazia parte dos marginalizados [...].” (RILKE, 1979, p. 34).

106 “Eu, ainda assim, não podia evitar que meu medo crescesse. Sabia que, enquanto ele andava, tentando com infinito esforço parecer sereno e distraído, o terrível crispar-se acumulava-se no interior de seu corpo; a angústia com a qual ele sentia crescer em si cada vez mais aquela força terrível, essa angústia estava em mim mesmo, e eu o via agarrar-se à bengala quando começava a se sentir sacudido dentro de si mesmo. E a expressão dessas mãos era tão impiedosa e severa que pus todas as minhas esperanças na sua força de vontade, que deveria ser enorme. Mas o que significava, neste caso, a vontade? Chegaria o instante em que suas forças estariam no fim, não podia demorar muito. E eu, que andava atrás dele com o coração pulsando forte, ia juntando meu restinho de força, como se junta dinheiro, e, fitando suas mãos, pedia-lhe em silêncio que, se precisasse, se servisse um pouco dela." (RILKE, 1979, p. 42-43). 
(cf. RILKE, 1982, p. 61). Essa sequência traz à lembrança o conto de Edgar Allan Poe, "The man of the crowd", no qual o narrador-protagonista persegue um homem que caminha pelas ruas de Londres sem parecer ter rumo certo. No entanto, o personagem de Poe tipifica os transeuntes londrinos enquanto os observa da janela de um café, e passa a seguir esse homem em particular por causa de uma curiosidade irresistível e conclui, após muitas horas de voltas sem sentido pela cidade, que aquele é um homem que pertence à multidão, e não mais do que isso (cf. POE, 2003, p. 416-426). Malte, ao contrário, parece se aproximar daquele homem movido por uma certa empatia.

Aqui, o exercício do olhar está em ação, mas é diferente do olhar do personagem de Poe, interessado em especular qual seria o sentido da caminhada ziguezagueante do homem na multidão. Na percepção de Malte, não há separação entre sujeito e objeto, interior e exterior, e é por isso que ele se angustia e divide suas forças com o homem: mais do que sentir empatia, ele parece dividir com o homem o sofrimento provocado pelos movimentos involuntários. Após perdê-lo de vista, Malte sente-se completamente extenuado: "Was hätte es für einen Sinn gehabt, noch irgendwohin zu gehen, ich war leer. Wie ein leeres Papier trieb ich an den Häusern entlang, den Boulevard wieder hinauf." 107 (RILKE, 1982, p. 61). A transformação de Malte parece ter avançado: como um papel em branco, ele se tornou um suporte, um recipiente, no qual se registra a impressão (Eindruck) causada pela caminhada espasmódica do homem.

107 "Que sentido teria em ir para qualquer lugar? Eu estava vazio. Como um papel vazio fiquei a me arrastar ao longo das casas, e novamente subi o bulevar.” (RILKE, 1979, p. 43). 


\section{Die Aufzeichnungen e o pensamento de Rilke sobre arte}

\subsection{O percurso estético de Rilke}

Na obra de Rilke, não é uma tarefa simples estabelecer uma distinção entre sua produção mais comumente categorizada como literária - seu trabalho de poesia e prosa, que inclui o romance Die Aufzeichnungen - e sua produção crítica - isto é, seu trabalho de reflexão sobre arte e literatura. Isso ocorre pelo fato de que, em Rilke, o pensamento sobre arte é um dos principais temas de seu romance e de sua poesia, em especial Sonette an Orpheus e Duineser Elegien, o que dá a essas obras também o caráter de texto estético (cf. $\mathrm{KOCH}, 2013$, p. 480). Por outro lado, sua produção mais específica sobre arte, como as monografias Worpswede e Auguste Rodin, apesar de não serem textos ficcionais, são dotados de qualidades literárias, intensamente permeados de imagens poéticas. A dificuldade com a terminologia vai além: Horst Nalewski explica que o termo Schriften (aqui traduzido como “escritos") é utilizado pelos estudiosos da obra rilkeana para abarcar textos de diversas naturezas, que foram especificados de diferentes maneiras por Rilke: "Rezension, Besprechung, Vortrag, Aufsatz, offener Brief, Monographie, Gutachten, Anzeige, Aufzeichnung, Anmerkung, Zuschrift, Tagebucheintragung, Notiz, Geleitwort, Gedenkblatt, Brief."108 (NALEWSKI, 1996, p. 751). Dentre essa variedade de gêneros textuais empregados, chama a atenção o uso do termo Aufzeichnung ${ }^{109}$, o mesmo utilizado para dar título ao seu romance de 1910. A escolha dessa terminologia, já discutida no primeiro capítulo desta dissertação, contribui para dar ao romance a dimensão de escrito reflexivo e programático sobre arte, desta vez sob um ponto de vista ficcional.

Horst Nalewski considera que a maior parte dos escritos estéticos de Rilke foi produzida entre os anos de 1893 e 1904, sendo que o início da redação do romance Die Aufzeichnungen, em 1904, teria sido a culminação de um processo de desenvolvimento artístico de Rilke (cf. NALEWSKI, 1996, p. 751). Um breve exame da biografia do poeta mostra que seu interesse ativo pelas artes visuais teve um papel de destaque nesse processo.

\footnotetext{
108 "Resenha, conferência, palestra, ensaio, carta aberta, monografia, parecer, anúncio, anotação, comentário, comunicado, diário, nota, prefácio,testemunho, carta.” (Tradução nossa).

${ }^{109}$ Há, entre os escritos estéticos de Rilke, um texto fragmentário que recebeu - segundo Nalewski, do próprio autor - a designação "Aufzeichnung über Kunst". Trata-se de duas versões de um mesmo texto curto, escrito em meados de 1898. O manuscrito, que fez parte do espólio de Lou Andreas-Salomé, foi publicado apenas postumamente em uma edição das obras completas de Rilke (cf. NALEWSKI, 1996, p. 803).
} 
Através do estudo da obra e dos métodos de trabalho de diferentes artistas, mas sobretudo de Rodin e de Cézanne, Rilke procurou definir o que significa ser artista. A reflexão estética de Rilke está intimamente relacionada a um pensamento sobre o papel da visão na criação artística, que pode ser observado em seus poemas - desde o poema de 1899 que abre Das Stundenbuch -, em seu romance Die Aufzeichungen e em seus escritos sobre arte. Sua concepção do olhar do artista passaram por desdobramentos e transformações que culminaram com o contato com as obras de Rodin e de Cézanne em 1902 e 1907, respectivamente. Com os aprendizados advindos da obra e dos métodos de trabalho de ambos os artistas franceses, Rilke expande e aprofunda sua reflexão sobre o olhar, que irá motivar as transformações em sua poesia. Ainda que o poeta já viesse construindo um percurso de pensamento estético anos antes, a experiência parisiense é paradigmática em sua trajetória, e é também a partir dela que Rilke compõe as Aufzeichnungen. Este capítulo tem como objetivo, primeiramente, traçar relações entre reflexões de Rilke articuladas em textos anteriores ao encontro com Rodin em 1902, e, em seguida, investigar a monografia sobre o escultor francês e as cartas sobre Cézanne, procurando analisar o entendimento que Rilke teve do trabalho desses artistas, com especial atenção ao tema do olhar. Por fim, retomaremos o texto das Aufzeichnungen à luz das análises dos escritos estéticos mencionados, para construir uma leitura do romance rilkeano como texto estético-programático.

Rilke começou cedo a publicar seus poemas e contos em revistas, e em 1895 matriculou-se na Deutsche Carl-Ferdinands-Universität em Praga, onde iniciou seus estudos em Literatura, História e Arte. No ano seguinte, passou a estudar Direito, com o objetivo de assumir o escritório de seu tio, cuja herança o financiava. No segundo semestre de 1896, no entanto, mudou-se para Munique com o amigo e pintor Emil Orlik, onde conheceu diversos artistas e escritores, em particular a escritora Lou Andreas-Salomé, de quem se tornou amigo. Em 1898, mudou-se para Berlim, onde permaneceu até o início de 1901. De acordo com Joachim Storck, nesse intervalo de tempo Rilke continuava seus estudos sem dedicar-lhes muita atenção, enquanto sua produção literária aumentava (cf. STORCK, 2013, p. 3). Também o desenvolvimento de seu pensamento sobre arte se intensificava e se diversificava. Com Lou Andreas-Salomé, Rilke viajou para a Toscana em 1898. Ainda naquele mesmo ano, viajou sozinho para Florença, onde escreveu um diário para a amiga, Das Florenzer Tagebuch. Depois, com Lou e seu marido, Rilke fez uma viagem à Rússia, em 1899. As viagens à Itália motivaram o poeta a escrever sobre a arte do Renascimento Italiano; a viagem à Rússia teve um impacto maior ainda em Rilke, que passou a dedicar-se a estudar arte russa. 
A viagem à Rússia também reverberou na escrita dos poemas da primeira parte de Das Stundenbuch, "Das Buch vom mönschischen Leben" (1899).

As viagens de Rilke foram relevantes para seu processo de estudo e reflexão sobre as artes visuais, e marcam o início de sua trajetória de produção de textos de crítica e história da arte. Em 1900, Rilke viajou pela segunda vez com Lou para a Rússia e, na volta para a Alemanha, foi para Worpswede a convite do amigo e pintor Heinrich Vogeler. Lá, o poeta conheceu uma comunidade de artistas, aproximou-se do pintor Otto Modersohn, da pintora Paula Becker, de sua irmã Milly, e da escultora Clara Westhoff, com quem se casou no ano seguinte (cf. STORCK, 2013, p. 4). Em paralelo a essas viagens e à escrita de poesia, Rilke escreveu o ensaio "Russische Kunst" em 1901, publicado na revista austríaca Die Zeit, cuja seção dedicada às artes visuais estava na época aos cuidados do historiador da arte Richard Muther, o mesmo que, no ano seguinte, encomenda a Rilke a monografia sobre o escultor Auguste Rodin. No início de 1902, com o término do fundo deixado por seu tio, Rilke viu-se em apuros financeiros e aceitou o pedido de Gustav Pauli, diretor do Bremer Kunsthalle, para que escrevesse um livro sobre os pintores de Worpswede. Durante todo esse período de intenso contato com as artes visuais, Rilke se manteve ativamente a par da produção literária de seus contemporâneos, tendo produzido, por exemplo, resenhas sobre livros de Thomas Mann - foi um dos primeiros a escrever sobre Buddenbrooks -, Hermann Hesse, Jakob Wassermann, entre outros. Resenhou ainda obras de autores escandinavos, em especial Jens Peter Jacobsen e Henrik Ibsen, introduzindo-os dessa forma aos leitores alemães (cf. NALEWSKI, 1996, pp. 753-754). Ainda que no decorrer de sua vida seu trabalho poético tenha prevalecido em relação à sua produção crítica e teórica, é o contato e a reflexão sobre as artes visuais que promovem o processo de transformação da poesia de Rilke, pois são centrais em seu entendimento da criação literária.

Esse pequeno resumo do começo da trajetória de reflexão do poeta sobre as artes visuais ilustra, como observa Antje Büssgen, o fato de que no início de seus estudos Rilke não procurou especializar-se em uma determinada época ou linguagem. Seus interesses estendiam-se dos ícones religiosos russos ao Impressionismo, do Renascimento Italiano às produções de seus contemporâneos; abrangiam diversas linguagens, da arquitetura ao teatro, da pintura à escultura (cf. BÜSSGEN, 2013, p. 130). No entanto, é notório como, ao longo do tempo, seu olhar foi se voltando cada vez mais para o trabalho de artistas modernos que seriam essenciais no desenvolvimento de seu próprio projeto estético. Esse entrelaçamento 
entre os estudos e questionamentos sobre arte e a produção literária se intensificou após sua viagem a Paris em 1902 para trabalhar com Rodin.

O encontro com o escultor francês afetou significativamente a trajetória do poeta: os aprendizados recebidos no período de maior convívio foram determinantes para o desenvolvimento de uma nova abordagem da escrita poética nos Neue Gedichte, de 1907, que marcam uma virada estética na lírica rilkeana. O impacto do encontro com Rodin foi amplamente documentado e ressaltado pelo próprio Rilke nas cartas escritas entre 1902 e 1904 (cf. RILKE, 1929, p. 26-42, p. 110-117 e p. 154). Evidencia-se sobretudo na monografia publicada em 1903 e na conferência que Rilke proferiu pela primeira vez em outubro de 1905 em Dresden, e diversas vezes entre os anos de 1905 e 1907 em Berlin, Praga, Paris e Viena, entre outras cidades (cf. HOFFMANN, 2010, p. 543-544).

Diversos estudiosos investigaram a experiência parisiense de Rilke, sua ligação com as artes visuais e com Rodin em particular ${ }^{110}$. Em sua maior parte, esses trabalhos procuram situar a relação que o poeta teve com o escultor no contexto do desenvolvimento de sua obra poética, procurando compreender como Rilke elabora seu próprio projeto estético a partir de premissas da criação escultórica de Rodin e de que maneiras esse projeto inovou sua poesia. Sem dúvida, o encontro com Rodin merece destaque, mas é importante ressaltar que até aquele momento Rilke já vinha construindo um percurso de pensamento sobre as artes visuais. Esse percurso se expressa, por exemplo, na palestra "Moderne Lyrik", no ensaio “Über Kunst” e no Florenzer Tagebuch, todos de 1898, e na monografia Worpswede, escrita em 1902. Apesar de algumas de suas ideias terem se modificado ao longo do tempo, outras parecem ter se consolidado em Paris.

Rilke havia criado uma grande expectativa em relação ao encontro com o escultor: seu interesse pelo trabalho de Rodin havia sido despertado pelos artistas de Worpswede. Clara Westhoff havia tido Rodin como mestre por um pequeno período entre 1899 e 1900 (cf. NALEWSKI, 1996, p. 928-929) e contou a Rilke sobre a experiência. Em uma carta a Clara

${ }^{110}$ BOEHM, Gottfried (org.). Rilke und die bildende Kunst. Frankfurt am Main: Insel, 1985; EMDE, Ursula. Rilke und Rodin. Marburg: Kunstwiss. Seminar, 1949; ENGELHARDT, Hartmut (org.). Materialien zu Rainer Maria Rilke "Die Aufzeichnungen des Malte Laurids Brigge". Frankfurt am Main: Suhrkamp, 1974; KOPP, Michaela. Rilke und Rodin. Auf der Suche nach der wahren Art des Schreibens. Frankfurt am Main: Peter Lang, 1999; KRIESSBACH, Martina. Rilke und Rodin: Wege einer Erfahrung des Plastischen. Frankfurt am Main: Peter Lang, 1984; NIVELLE, Armand. "Rilke, Rodin und die Forschung". In: MOOGGRÜNEWALD, Maria e RODIEK, Christoph (org.). Dialog der Künste: Intermediale Fallstudien zur Literatur des 19. und 20. Jahrhunderts. Frankfurt am Main: Peter Lang, 1989; RIOS, Rita. Poemas e pedras. A relação entre a escultura e a poesia partindo de Rodin e Rilke. São Paulo: Edusp, 2011; SCHNEDITZ, Wolfgang. Rilke und die bildende Kunst: Versuch einer Deutung. Graz: J. A. Kienrich, 1947. 
de 18 de novembro de 1900, o poeta expressou seu desejo de que escrevessem conjuntamente a respeito do artista francês: "Wir müßten einmal zusammen einem Aufsatz schreiben über ihn!"111 (RILKE, apud NALEWSKI, 1996, p. 929). Em 1902, Richard Muther, que na época editava uma coleção de livros populares sobre arte, encomendou a Rilke uma monografia sobre o escultor. Antes de viajar a Paris em setembro daquele ano, o poeta correspondeu-se com Rodin, a quem chamava de "Maître", não só para explicar a natureza do livro dedicado à obra do escultor ("votre œuvre") que iria escrever, mas também para revelar que o livro seria, para ele mesmo e para seu trabalho de escritor e poeta, "um grande acontecimento" ("un grand évènement").

Je vous ai écrit de Haseldorf, que le mois septembre je serais à Paris, pour me préparer à ce livre consacré à votre œuvre. Mais ce que je ne vous ai encore dit, c'est qu'il sera pour moi-même, pour mon travail (le travail d'écrivain ou bien de poète) un grand évènement de m'approcher de vous. Votre art est tel (je l'ai senti depuis longtemps) qu'il sait donner du pain et de l'or aux peintres, aux poètes, aux sculpteurs: à tous les artistes, qui vont leur chemin de douleur ne désirant autre chose que ce rayon d'éternité qui est but suprême de la vie créante. ${ }^{12}$ (RILKE, 1929 , p. 16). ${ }^{113}$

É notável observar que o encontro com Rodin já aparece nesse primeiro relato como a experiência transformadora da vida do poeta. Ainda na mesma carta, Rilke afirma: "Toute ma vie s'est changé, dès que je sais, que vous êtes, mon Maître, et que le jour, où je vous verais, est un (et peut-être le plus hereux) de mes jours." ${ }^{114}$ (RILKE, 1929, p. 17). Após visitar o ateliê de Rodin pela primeira vez, ele narrou a visita a Clara em uma carta de 2 de setembro de 1902, dando muitos detalhes, como se quisesse registrar o momento exato em que adentrou o universo do escultor:

Gestern, Montag nachmittag, 3 Uhr, war ich zuerst bei Rodin. Atelier Rue de l'Université 182. Bin auf der Seine hingefahren. Er hatte Modell. Ein Mädchen, hatte ein kleines Gipsding in der Hand, an dem er herumkratzte. Er ließ die Arbeit

111 "Nós precisamos um dia escrever juntos um ensaio sobre ele!” (Tradução nossa).

112 "Eu lhe escrevi de Haseldorf que no mês de setembro estarei em Paris para me preparar para [escrever] esse livro consagrado à sua obra. Mas o que ainda não lhe havia dito, é que será para mim, para meu trabalho (o trabalho de escritor ou mesmo de poeta) um grande acontecimento aproximar-me de você. Sua arte é tal (eu já havia sentido há bastante tempo) que ela sabe dar pão e ouro aos pintores, aos poetas, aos escultores: a todos os artistas, que seguem seus caminhos de dor, não desejando outra coisa que esse raio de eternidade que é o objetivo supremo da vida criadora.” (Tradução nossa).

${ }^{113}$ Essa passagem revela o entendimento que Rilke tinha da arte como forma de elevação semelhante à elevação espiritual - uma concepção que já havia expressado em textos anteriores, notadamente no Florenzer Tagebuch (cf. KOCH, 2013, p. 484) - e já adianta o tom que utilizará depois na monografia para retratar Rodin como uma figura sacra.

114 "Toda minha vida mudou, desde que eu soube que és meu mestre, e que o dia, em que eu o verei, é um (e talvez o mais feliz) de meus dias." (Tradução nossa). 
im Stich, bot mir einen Sessel an, und wir sprachen. Er war gut und mild. Und mir war, als kennte ich ihn immer schon. Als sähe ich ihn nur wieder; ich fand ihn kleiner und doch mächtiger, gütiger und erhabener. ${ }^{115}$ (RILKE, 1929, p. 26).

No escultor francês, Rilke encontrou um artista que se dedicava inteiramente ao trabalho - "travailler, rien que travailler"116 - trabalhava solitário - "[...] so wuchs sein Werk in Reinheit heran, allein mit sich und mit einer großen ewigen Natur." ${ }^{117}$ (RILKE, 1996, p. 414) e sempre criava suas peças a partir apenas do que observava - "Er gab seiner Phantasie nicht Raum; er erfand nicht."118 (RILKE, 1996, p. 433). Além disso, a superfície de suas esculturas revelava uma técnica de modelagem cuidadosamente elaborada. A ênfase do trabalho artístico de Rodin se dava nos processos, não na obra final, o que o tornava um exemplo de artista moderno, que atuava de acordo com um conjunto rigoroso de premissas próprias. No centro dessas premissas está o ofício do olhar ${ }^{119}$. E embora Rilke tenha reforçado - nas cartas de 1902 e no título que deu ao volume de poemas escritos em Paris, Neue Gedichte, de 1907 - que o período de convivência com Rodin havia mudado sua vida e, consequentemente, seu trabalho, parte dos pressupostos artísticos aprendidos já haviam sido esboçados em seus textos anteriores à monografia sobre o escultor, inclusive o papel do olhar.

Com Rodin, e posteriormente também no contato com as pinturas de Cézanne, o aprendizado do olhar se intensificou, trazendo consigo questões sobre a materialidade, ou o tornar-se coisa (Dingwerdung) na obra de arte. Os Neue Gedichte marcam de fato uma virada estética na poesia rilkeana, pois neles Rilke escreveu seus poemas a partir do olhar objetivo aprendido com os dois artistas franceses, e precisou, para isso, modelar um novo uso da linguagem, buscando trabalhar com a materialidade das palavras. Strathausen argumenta que os Neue Gedichte demandam que o leitor "arque com o fardo de olhar", como precisa fazer o espectador das obras de Rodin e Cézanne. "To see things is to read without reading and to

\footnotetext{
115 “Ontem, segunda-feira à tarde, 3 horas, estive pela primeira vez com Rodin. Ateliê Rue de l'Université, 182. Ele tinha um modelo. Uma jovem, tinha uma pequena coisa de gesso na mão, em torno da qual ele raspava. Ele deixou o trabalho, ofereceu-me uma cadeira e nós convsersamos. Ele era bom e suave. E a mim parecia já conhecê-lo desde sempre. Como se eu o visse novamente; o encontro menor e ainda mais poderoso, benévolo e sublime." (Tradução nossa).

116 “trabalhar, nada além de trabalhar" (Tradução nossa).

117 “Assim [...] desenvolvia-se a sua obra com pureza, estando ele sozinho consigo mesmo e com uma imensa, eterna natureza.” (RILKE, 2003, p. 28).

118 “Ele não permitia que sua imaginação se expandisse; ele não inventava nada.” (RILKE, 2003, p. 54).

${ }^{119}$ Esse aspecto será investigado com mais profundidade nas próximas seções deste capítulo.
} 
unlearn 'known' language in an effort to look at words differently without losing them from sight altogether."120 (STRATHAUSEN, 2003, p. 198). Uma vez que seu meio de trabalho difere substancialmente do de Rodin e do de Cézanne, Rilke decompõe as normas da linguagem e trata as palavras como unidades materiais por si mesmas, de forma a buscar que seus poemas apresentem coisas ao leitor. O romance Die Aufzeichnungen, por sua vez, nos interessa aqui como objeto de investigação por causa de seu caráter programático: o protagonista Malte narra seu processo de aprendizado do olhar, e de elaboração de um projeto estético a partir desse aprendizado.

Neste capítulo, serão trazidas para a discussão sobre as premissas estéticas desse projeto algumas passagens de textos anteriores à monografia sobre Rodin. Os textos selecionados são de naturezas diferentes, mas têm em comum reflexões sobre o que significa ser artista e qual seve ser o objetivo, ou a natureza, da obra de arte. Neles, repetem-se algumas premissas, como a concepção do artista como solitário, e a relação entre o artista e a infância. Uma premissa importante que aparece nesses textos e nos interessa investigar, transforma-se com o passar dos anos: a do papel do olhar na arte. A seleção de textos inclui uma palestra, “"”Moderne Lyrik”, apresentada em Praga em março de 1898; um diário pessoal escrito para a amiga Lou Andreas-Salomé durante uma viagem a Florença em 1898; um ensaio intitulado "Über Kunst", escrito entre julho e agosto de 1898 em resposta ao livro Was ist Kunst? de Tolstoi, que havia sido publicado no ano anterior; a introdução à monografia sobre os artistas da colônia de Worpswede, de 1902, livro que Rilke escreveu por encomenda de um editor; e a primeira versão da introdução à monografia Worpswede, intitulada "Von der Landschaft", de 1902, e que só veio a ser publicada postumamente. Por fim, serão analisados mais detidamente: a monografia Auguste Rodin, escrita por encomenda do historiador da arte Richard Muther também em 1902, e a seleção Briefe über Cézanne, parte da correspondência pessoal do poeta que foi editada por sua esposa Clara Rilke-Westhoff apenas em 1952.

Esta seção investiga as ideias que se relacionam com o aprendizado ou tarefa do olhar, procurando analisar como a noção do olhar no fazer artístico ganha importância e se aprofunda no pensamento estético de Rilke, e qual seu papel em seu projeto estético. $\mathrm{O}$ objetivo deste capítulo é traçar relações entre a análise do olhar nos escritos estéticos mencionados e o projeto estético delineado em Die Aufzeichnungen. Com isso, procuraremos aprofundar a leitura do romance como texto programático, partindo da hipótese de que as

\footnotetext{
120 "Ver as coisas é ler sem leitura e desaprender a linguagem 'conhecida' em um esforço para olhar para as palavras de modo diferente sem, ao mesmo tempo, perdê-las de vista.” (Tradução nossa).
} 
Aufzeichnungen esboçam essas premissas artísticas ao longo das narrativas do protagonista Malte sobre seus próprios processos de aprendizado e autodescoberta. Vistas em conjunto, como um pensamento gradativamente desenvolvido por Malte, elas poderiam ser entendidas como o delineamento de um projeto estético que coincide com o projeto do próprio Rilke para sua obra lírica.

\subsection{Primeiros escritos}

O ano de 1898 foi particularmente prolífico para o percurso rilkeano no campo da história da arte. Em março, Rilke apresentou em Praga a palestra "Moderne Lyrik", na qual expôs suas ideias sobre o que torna uma pessoa artista, qual o elemento fundamental da lírica e o que a torna moderna, para depois discorrer sobre a poesia de alguns de seus contemporâneos. No início da palestra, Rilke afirma que tornar-se artista implica atravessar aprendizados pré-estabelecidos e perscrutar o fundo da própria interioridade em busca do que é novo e ainda não dito, para assim aproximar-se intimamente da arte, em um processo que só pode ser feito na solidão (cf. RILKE, 1996, p.62). Mas adverte sua audiência de que a arte “[...] nur ein Weg ist, nicht ein Ziel." ${ }^{21}$ (RILKE, 1996, p. 62), não deve estar a serviço de qualquer demanda política ou social de seu tempo - nesse caso, poderia ser considerado "[...] gereimter oder gemalter Journalismus [...]." ${ }^{122}$, mas não arte (RILKE, 1996, p. 63). Opondo-se também à ideia de que a arte seja mera imitação da natureza, Rilke explica seu próprio entendimento:

Kunst erscheint mir als das Bestreben eines Einzelnen, über das Enge und Dunkle hin, eine Verständigung zu finden mit allen Dingen, mit den kleinsten, wie mit den größten, und in solchen beständigen Zwiegesprächen näher zu kommen zu den letzten leisen Quellen alles Lebens. Die Geheimnisse der Dinge verschmelzen in seinem Innern mit seinen eigenen tiefsten Empfindungen und werden ihm, so als ob es eigene Sehnsüchte wären, laut. Die reiche Sprache dieser intimen Geständnisse ist die Schönheit. ${ }^{123}$ (RILKE, 1996, p. 65).

\footnotetext{
121 “[...] é apenas um caminho, não um objetivo.” (Tradução nossa).

122 “[...] jornalismo rimado ou pintado [...].” (Tradução nossa).

123 “Arte me parece ser como o esforço de um indivíduo, por entre a limitação e a obscuridade, de encontrar uma comunicação com todas as coisas, tanto com a menor delas como com a maior, e com tal diálogo consistente, afinal aproximar-se gentilmente da fonte de toda vida. Os segredos das coisas se fundem em seu interior com suas próprias percepções e se tornam parte dele, como se fossem seus próprios anseios, estrondosos. A linguagem opulenta dessas confissões íntimas é a beleza.” (Tradução nossa).
} 
$\mathrm{O}$ artista deveria, em sua visão, buscar conhecer profundamente o mundo e a si mesmo, uma vez que a arte seria o resultado de um amálgama de ambos, os segredos das coisas e a interioridade do artista. A esse entrelaçamento entre mundo e subjetividade individual, Rilke chama de "intime Geständisse" 124 : algo secreto, que o artista pode de certa forma traduzir em sua obra, através da beleza, tornando-o acessível a um número maior de pessoas.

"Wenn alle Künste Idiome der Schönheitssprache sind, so werden die feinsten Gefühlsoffenbarungen, um welche es sich handelt, am klarsten in derjenigen Kunst erkennbar sein, welche im Gefühle selbst ihren Stoff findet, in der Lyrik."125 (RILKE, 1996, p. 65). Com essa constatação, Rilke reafirma uma noção de que a poesia encontra seu principal material nos sentimentos do artista, mas também a amplia, exemplificando de que maneiras a junção entre mundo e subjetividade individual pode ser feita:

Aber selbst dieser Gefühlsstoff, mag es eine Abendstimmung oder eine Frühlingslandschaft sein, erscheint mir nur der Vorwand für noch feinere, ganz persönliche Geständnisse, die nichts mit dem Abend oder dem Blütentag zu tun haben, aber bei dieser Gelegenheit in der Seele sich lösen und ledig werden. ${ }^{26}$ (RILKE, 1996, p. 65).

O sentimento do artista por si só não deve ser o elemento principal da obra: ele deve ser evocado a partir de outro tema, como uma paisagem. Sob essa concepção, a arte passaria a ter um objetivo oculto: ao invés de mostrar diretamente os sentimentos, ela procuraria suscitá-los no espectador ou leitor através de uma representação outra, de um objeto que sirva de pretexto para a evocação do sentimento desejado: assim, “[...] die reine Kunst-Absicht hervortritt hinter dem Kunst-Vorwand." 127 (RILKE, 1996, p. 65).

Para conseguir criar esse efeito com sua obra, o artista precisaria antes conhecer muito bem os temas que poderá usar como subterfúgio. Esse artista que busca uma comunhão com todas as coisas é descrito como alguém que, apartado do convívio social comum, possui uma sensibilidade única e, enquanto as pessoas que o cercam são hostis às mudanças, ele anseia por elas, as "revelações", das quais, se puder usar sua voz, será o enunciador. Essa posição, segundo Rilke, é semelhante à do religioso ou do político, mas difere deles na medida em que

\footnotetext{
124 “confissões íntimas” (Tradução nossa).
}

125 "Se todas as artes são idiomas da linguagem da beleza, então a manifestação mais sutil dos sentimentos, dos quais se trata, será mais perceptível naquela arte que encontra nos próprios sentimentos a sua matéria, na lírica.” (Tradução nossa).

126 "Mas essa matéria de sentimento, que pode ser uma atmosfera noturna ou uma paisagem de primavera, parece-me apenas o pretexto para confissões ainda mais sutis e muito pessoais, que nada têm a ver com a noite ou com a florada, mas que, por essa ocasião, lançam-se na alma e tornam-se livres.” (Tradução nossa).

127 “[...] a pura arte-intenção emerge de trás da arte-pretexto.” (Tradução nossa). 
estes se deixam confundir pela fama e perdem seus objetivos de vista (cf. RILKE, 1996, p. 68). Rilke diz que não sabe precisar quem de seus contemporâneos foi o primeiro a divisar essa possibilidade evocativa na arte. Mas explica que sua geração teve como vantagem o aprendizado adquirido de seus predecessores: "Der objektive Realismus vergangener Jahrzehnte hat ihn mit der Natur und dem Leben in Verkehr gebracht und sein Auge geübt für die Dimensionen der Dinge."128 (RILKE, 1996, p. 68). Se o "Idealismus der Objektivität"129 havia ensinado a olhar de outra forma para as coisas, ele havia falhado em seu propósito, de acordo com Rilke, a partir do momento em que "[...] man leise begann, statt von den Dingen, mit den Dingen zu sprechen, also: 'subjektiv' zu werden." ${ }^{130}$ (RILKE, 1996, p. 68, grifo do autor).

\begin{abstract}
Und nun folgte im Subjektivismus eine Parallelentwickelung, wie seinerzeit innerhalb der objektiven Welterkenntnis. Man lernte die eigene Seele betrachten, wie frührer die äußere Umgebung, man wurde auch hier Realist und Naturalist den intimen, inneren Sensationen, wie vorher den äußeren Ereignissen gegenüber und lernte wie früher die Welt, nun ebenso genau die eigene Seele kennen, das heißt man fand in sich selbst Alles reicher und vielgestaltiger wieder, was man in der objektiven Schulzeit außerhalb der eigenen Persönlichkeit gesucht hatte. ${ }^{131}$ (RILKE, 1996, p. 68, grifo do autor).
\end{abstract}

De acordo com esse ponto de vista, o Subjetivismo se desenvolve, portanto, a partir do aprendizado de uma maneira de olhar, objetiva, anteriormente usada para investigar o mundo, e que naquele momento passava a ser usada para investigar a si mesmo. Essa concepção era, na visão de Rilke, a forma mais elaborada do Subjetivismo. A investigação de si mesmo não trata, segundo Rilke, de olhar para os sentimentos de forma objetiva, mas de perceber que na interioridade se encontra tudo o que pode ser encontrado no espaço externo, mas mais rico e variado ("reicher und vielgestaltiger"). Com isso, o Subjetivismo coloca em cheque a problemática relação entre interior e exterior, que é imposta ao ideal do olhar objetivo, uma vez que a percepção do espaço externo necessariamente passa pela interioridade do artista.

\footnotetext{
128 “O realismo objetivo das décadas passadas o colocou em comunhão com a natureza e a vida e exercitou seu olho para as dimensões das coisas.” (Tradução nossa).

129 “idealismo da objetividade” (Tradução nossa).

130 “começou-se vagamente, ao invés de sobre as coisas, a falar com as coisas, portanto: a tornar-se 'subjetivo'." (Tradução nossa).

131 "E deu-se agora no subjetivismo um desenvolvimento paralelo ao que havia se dado naquele tempo no conhecimento objetivo do mundo. Aprendeu-se a contemplar a própria alma como antes [se contemplava] o ambiente externo, vieram a ser agora realistas e naturalistas das sensações íntimas, internas, como mais cedo, ao contrário, [se era] dos acontecimentos externos, e aprendeu-se a conhecer, como antes [se havia conhecido] o mundo, agora, da mesma forma, a própria alma, ou seja, encontrou-se em si mesmo, mais rico e diverso, tudo aquilo que durante a escola objetiva se havia procurado fora da própria individualidade." (Tradução nossa).
} 
Por isso Rilke aponta que, ao invés, de falar das coisas, fala-se com as coisas: a percepção do artista é singular, mas investigá-la é algo que demanda um imenso trabalho que, na visão de Rilke, deve ser feita na solidão.

A solidão não é apresentada pelo poeta como uma consequência negativa da investigação do artista; ela é mostrada como tendo um efeito positivo, ou ainda, inovador: "Und weil die Einsamkeit leise und lauschend macht, vernahm dieser kosmische Eremit Vieles, was bislang niemand vernommen hatte."132 (RILKE, 1996, p. 69). Na solidão, o artista encontra possibilidades para abrir seus sentidos a novas sensações, experiências e conhecimentos que, segundo o autor, não teriam sido acessados por ninguém antes. Assim, Rilke chega ao ponto central de seu argumento: a inovação trazida pela lírica moderna de seus contemporâneos é apresentar novos sentimentos: "nеuе Freude", "neue Leiden", "neue Sehnsucht"133 (cf. RILKE, 1996, p. 69). Por estarem relacionados à intimidade dos artistas e ao mundo, os novos sentimentos, ao mesmo tempo em que são íntimos, seriam também dotados de uma dimensão coletiva.

Alguns fundamentos da palestra "Moderne Lyrik" foram retomados pelo poeta em outros escritos daquele mesmo ano, em especial no diário que manteve entre os meses de abril e junho em Florença (Das Florenzer Tagebuch) e no ensaio "Über Kunst". Em comum com a palestra, ambos os escritos reforçam o ideal do artista como o solitário que vive em constante conflito em relação ao mundo. De acordo com Rilke, a arte está para o solitário tal qual a religião, a ciência e a política estão para os indivíduos que se dedicam a elas: são modos de vida, e seriam para ele o caminho da autorrealização ou liberdade individual (RILKE, 1996, p. 114; RILKE, 2002, p. 36). Porém, enquanto o artista buscaria obstinadamente em sua arte aquilo que a sociedade não teria ainda meios para compreender, esta se esforçaria em ridicularizar e demonizar o artista, por não compreendê-lo: "Reside atualmente uma brutalidade indizível nas relações entre a multidão e o artista." (RILKE, 2002, p. 36). Por isso a realização do artista deve acontecer no recolhimento, na solidão, no processo de voltar à sua própria interioridade, um processo que deve ocorrer de maneira tranquila: “Após esse retorno a seu íntimo, cada feito é uma alegria repleta de paz interior; sua vida é uma criação, e não há mais necessidade das coisas que se encontram no exterior.” (RILKE, 2002, p. 37). Rilke retoma, assim, a definição da arte como uma confissão íntima: ela é “[...] ein tiefinneres

\footnotetext{
132 "E porque o solitário age quieto e atentamente, esse eremita cósmico escuta muitas coisas, que ninguém havia escutado até então.” (Tradução nossa).

133 “"nova alegria”, “novo sofrimento", “novo anseio" (Tradução nossa).
} 
Geständnis, das unter dem Vorwand einer Erinnerung, einer Erfahrung oder eines Ereignisses sich ausgiebt und, losgelöst von seinem Urheber, allein bestehen kann."134 (RILKE, 1996, p. 115). De acordo com Manfred Koch, há nessa frase uma referência à declaração de Goethe de que toda sua obra teriam sido "Bruchstücke einer großen Konfession"135 (cf. KOCH, 2013, p. 483).

Por extrair de si mesmo a matéria de sua arte, o artista seria um personagem sem passado, descolado também temporalmente das demais pessoas. A obra de arte produzida, sendo fruto desse mergulho interior, necessariamente transpareceria algo da sua subjetividade, mas, uma vez colocada no mundo, ela adquiriria uma existência própria, independente do artista (cf. RILKE, 1996, p. 115). O ensaio "Über Kunst" é uma defesa da autonomia da arte: aqui, Rilke retoma a ideia de que a arte, sendo um modo de vida, é um meio, não um fim; não deve estar ligada a nenhum objetivo político ou social. Ela deve, antes, tratar da vida no sentido mais amplo - e atemporal (cf. KOCH, 2013, p. 482). Está posta aqui novamente a ideia de que a arte não é um objetivo, mas um caminho, expressada na palestra "Moderne Lyrik". Este é um ponto em comum também com a palestra sobre Rodin que Rilke profere entre 1905 e 1907, pois o escultor é retratado por Rilke como um artista que teria atingido, através da dedicação ao trabalho e do desenvolvimento de seus próprios métodos e processos, uma espécie de verdade artística, que o confere uma posição praticamente divina (cf. HOFFMANN, 2010, p. 559-560). A arte tem, para Rilke, um potencial transformativo, tanto para o artista quanto para o espectador, como será discutido mais adiante neste capítulo, na seção sobre a monografia Auguste Rodin.

O modo de estar no mundo da arte é, de acordo com Rilke, semelhante à infância: "Man erkennt: diese Art zu sein hat etwas Naives und Unwillkürliches und ähnelt jener Zeit des Unbewußten an, deren bestes Merkmal ein freudiges Vertrauen ist: der Kindheit. Die Kindheit ist das Reich der großen Gerechtigkeit und der tiefen Liebe." ${ }^{36}$ (RILKE, 1996, p. 116). Isso porque a percepção do mundo na infância é toda composta por primeiras

\footnotetext{
134 “[...] uma confissão profunda e íntima que pode se esgotar sob o pretexto de uma lembrança, de uma experiência ou de um acontecimento e, emancipada de seu autor, pode existir sozinha." (RILKE, 2011, p. 134).

135 "fragmentos de uma grande confissão" (Tradução nossa).

136 "Reconhecemos: essa forma de ser tem algo de ingênuo e involuntário e se assemelha àquele tempo do inconsciente cuja melhor característica é uma confiança contente: a infância. A infância é o reino da grande justiça e do amor profundo.” (RILKE, 2011, p. 135).
} 
impressões, porque tudo é novo e despido de conceitos aos olhos da criança. Na infância ${ }^{137}$ haveria uma abertura total dos sentidos para relacionar-se com as coisas de maneira direta, sem intermediações; para Rilke, as percepções da infância são de imensa riqueza, mas são gradativamente desvalorizadas à medida que a criança passa a receber a educação tradicional e suas impressões iniciais são tamponadas por camadas de conceituação histórica e científica (cf. RILKE, 1996, p. 117).

$\mathrm{Na}$ introdução à monografia sobre os pintores da colônia de artistas de Worpswede, de 1902, Rilke recorre novamente à imagem da infância para descrever uma forma de abertura dos sentidos e de conexão com o mundo: segundo ele, enquanto uma pessoa comum vê na natureza apenas aquilo de que ela possa tirar proveito, percebendo apenas “"[...] die Oberfläche der Dinge [...]"138 (RILKE, 1996, p. 310), as crianças, especialmente as crianças solitárias, são “[...] ähnlich den kleinen Tieren, ganz hingegeben an die Ereignisse des Waldes und des Himmels und in einem unschuldigen, scheinbaren Einklang mit ihnen."139 (RILKE, 1996, p. 310). Ao contrário da maioria das crianças, que ao crescerem abandonam aos poucos esse vínculo, o artista é aquele que se mantém, de certa forma, no modo da infância e se dedica, na linguagem que lhe cabe, a se relacionar com a natureza ou, na impossibilidade disso, a procurar compreendê-la e nela inserir-se ${ }^{140}$, tornando a arte espécie de mediadora entre o ser

\footnotetext{
${ }^{137}$ Não à toa, também na palestra sobre Rodin, Rilke pede às pessoas da plateia que procurem lembrar-se de suas próprias infâncias. De acordo com Hoffmann, Rilke utilizava esse recurso retórico após pedir que esquecessem o nome de Rodin para que a audiência se desligasse de suas expectativas por uma palestra convencional e se voltasse à sua própria experiência. $\mathrm{O}$ intuito era fazer com que os espectadores sentissem suas histórias pessoais ligadas, de certo modo, à obra de Rodin, enquanto Rilke dava seguimento à sua abordagem estéticoantropológica do trabalho do escultor francês. Esse recurso tem um aspecto duplo, de uma tentativa de manter o controle da recepção do conteúdo e estimular o público a engajar-se ativamente na palestra (cf. HOFFMANN, 2010, p. 555-556)

138 “[...] a superfície das coisas [...]” (Tradução nossa).

139 " [...] semelhante aos pequenos animais, totalmente devotadas aos acontecimentos da floresta e do céu e em uma inocente e ostensiva harmonia com eles.” (Tradução nossa).

140 "Dichter oder Maler, Tondichter oder Baumeister, Einsame im Grunde, die, indem sie sich der Natur zuwenden, das Ewige dem Vergänglichen, das im tiefsten Gesetzmäßige dem vorübergehend Begründeten vorziehen, und die, da sie die Natur nicht überreden können, an ihnen teilzunehmen, ihre Aufgabe darin sehen, die Natur zu erfassen, um sich selbst irgendwo in ihre großen Zusammenhänge einzufügen." (RILKE, 1996, p. 311) ["Poeta ou pintor, compositor ou arquiteto, solitário no âmago, quem, ao voltar-se para a natureza, prefere o eterno ao efêmero, [prefere] o que é profundamente constitucional ao que é intrinsecamente transitório, e que, por não conseguirem convencer a natureza a partilhar com eles, vêem sua tarefa como apreender a natureza para imiscuir-se a ela em algum lugar de seu grande contexto." (Tradução nossa).]
} 
humano e a natureza ${ }^{141}$. Com esse preceito, surge no centro do procedimento de trabalho do artista o olhar.

O tema do olhar também aparece de maneira interessante no texto "Von der Landschaft". Escrito no início de 1902, "Von der Landschaft" é considerado pela crítica como a primeira versão da introdução à monografia Worpswede e foi publicado apenas postumamente, em um periódico literário da Insel Verlag (o "Insel-Almanach") de 1933, em Leipzig (cf. NALEWSKI, 1996, p. 857). É curioso notar como nesse escrito Rilke retoma a noção de "Kunst-Vorwand", desenvolvida na palestra "Moderne Lyrik", e adianta o princípio do olhar objetivo, que ganhará mais importância depois do convívio com Rodin e as pinturas de Cézanne. "Von der Landschaft" é uma reflexão sobre as mudanças na concepção da paisagem na pintura ocidental. Rilke começa pela Grécia Antiga - na qual, afirma, o corpo humano era protagonista e a paisagem, apenas o lugar onde se vivia (cf. RILKE, 1996, p. 208) - e passa à arte cristã, na qual surge o problema da transitoriedade e da multiplicidade de paisagens: é preciso escolher entre representar o Céu, a Terra ou o Inferno. É nesse momento, segundo Rilke, que a concepção da paisagem como algo autônomo se consolida (cf. RILKE, 1996, p. 209) e, quando essa escolha se volta à representação da Terra, os artistas voltam o olhar ao mundo como pela primeira vez. (cf. RILKE, 1996, p. 209-210). O deslumbramento provocado por esse novo olhar teria levado a um novo tratamento na pintura, de louvor à glória e à beleza do mundo - e a paisagem, passado a ser tratada não mais como mero cenário, mas como algo em si mesmo dotado de sentido (cf. RILKE, 1996, p. 210).

A partir desse momento, Rilke aponta que houve uma grande mudança na pintura: "[...] man malte die Landschaft und meinte doch nicht sie damit, sondern sich selbst; sie war Vorwand geworden für ein menschliches Gefühl, Gleichnis einer menschlichen Freude, Einfalt und Frömmigkeit. Sie war Kunst geworden."142 (RILKE, 1996, p. 210, grifo do autor). Entre os primeiros artistas a perceberem o potencial de expressar sentimentos através de um tema, Rilke destaca Leonardo Da Vinci: de acordo com ele, as paisagens pintadas por Da Vinci, ao mesmo tempo “[...] sind Ausdrücke seines tiefsten Erlebens und Wissens [...].” e

\footnotetext{
${ }^{141}$ Essa concepção do artista como alguém que mantém vivo um interesse e uma curiosidade infantis pelas coisas ecoa a concepção que Baudelaire desenvolve do gênio no ensaio "Le peintre de la vie moderne". Esse tópico também será discutido mais aprofundadamente na seção sobre a monografia Auguste Rodin neste capítulo.

142 “[...] pintava-se a paisagem e não se aludia de fato a ela, mas a si mesmo; ela havia se tornado pretexto para um sentimento humano, metáfora para uma alegria humana, simplicidade e devoção. Ela havia se tornado arte." (Tradução nossa).
} 
“[...] ein Ausdrucksmittel empfand für fast unsagbare Erfahrung, Tiefe und Traurigkeit."143 (RILKE, 1996, p. 210). Na visão do poeta, a paisagem atrás da figura da Mona Lisa, retrato do início do século XVI, é exemplar: "Noch hat niemand eine Landschaft gemalt, die so ganz Landschaft ist und doch so sehr Geständnis und eigene Stimme wie jene Tiefe hinter der Madonna Lisa." ${ }^{144}$ (RILKE, 1996, p. 211). Com essa pintura, da Vinci havia realizado não só um pano de fundo para a mulher retratada em primeiro plano, mas um cenário pensado para compor um espaço realista e evocar sentimentos específicos que seriam as "intime Geständnisse" do artista.

Se, por esse viés, é a subjetividade de Da Vinci que se revela nessa pintura, por outro, Rilke começa a argumentar que, para representar uma paisagem como tal como ela é, é preciso abordá-la de outra maneira:

Diese Landschaft ist nicht eines Eindrucks Bild, nicht eines Menschen Meinung
über die ruhenden Dinge; sie ist Natur die entstand, Welt die wurde und dem
Menschen so fremd wie der niebetretene Wald einer unentdeckten Insel. Und
Landschaft so zu schauen als ein Fernes und Fremdes, als ein Entlegenes und
Liebloses, das sich ganz in sich vollzieht, war notwendig, wenn sie je einer
selbständigen Kunst Mittel und Anlaß sein sollte; denn sie mußte fern sein und sehr
anders als wir, um ein erlösendes Gleichnis werden zu können unserem Schicksal.
Fast feindlich mußte sie sein in erhabener Gleichgültigkeit, um unserem Dasein eine
neue Deutung zu geben mit ihren Dingen. ${ }^{145}$ (RILKE, 1996, p. 211).

Para representar uma paisagem naturalista, fazia-se necessário aprender a olhar para a natureza com distanciamento, estranhamento, alheamento - e isso, de acordo com Rilke, da Vinci compreendeu cedo. O poeta reforça que esse era um aprendizado difícil, que tomaria muitos anos até que fosse possível “[...] nicht länger mit dem voreingenommenen Auge des Einheimischen zu sehen, der alles auf sich selbst und auf seine Bedürfnisse anwendet, wenn er es schaut." ${ }^{466}$ (RILKE, 1996, p. 211). O hábito, o conhecimento construído coletivamente

\footnotetext{
143 “[...] são expressões de sua mais profunda vivência e conhecimento [...]." e "[...] um meio de expressão para a quase indizível experiência, profundeza e tristeza." (Tradução nossa).

144 "Ninguém ainda havia pintado uma paisagem que fosse tão completamente paisagem e, ao mesmo tempo, tanta confissão e voz própria como a profundidade atrás da Madonna Lisa.” (Tradução nossa).

145 “Essa paisagem não é uma imagem de impressões, não é uma opinião de uma pessoa sobre as coisas latentes; ela é natureza que emergiu, mundo que tornou-se para o homem tão estranha quanto a floresta não adentrada de uma ilha não descoberta. E olhar a paisagem como algo distante e alheio, como algo remoto e cruel, que ocorre apenas em si mesmo, era necessário, se ela deveria ser um meio artístico e uma razão autônomos; então ela devia ser distante e muito diferente de nós para que pudesse ser uma metáfora catártica de nosso destino. Quase hostil ela tinha que ser, em sublime indiferença, para dar à nossa existência, com suas coisas, uma nova interpretação." (Tradução nossa).
}

146 “não ver mais com o olho tendencioso do habitante local, que emprega todas as coisas a si mesmo e aos seus desejos, quando ele as vê.” (Tradução nossa). 
ou o preconceito, todos seriam assim fatores que atrapalhariam um olhar objetivo, que não julgasse ou fizesse suposições. O que Rilke postula é que, para conseguir despir o olhar de todas essas ideias pré-concebidas a respeito do mundo, era preciso de algum modo estar fora do mundo (cf. RILKE, 1996, p. 211), ou seja, passar por um processo essencialmente solitário, pois separar-se do mundo implica separar-se de todas as relações.

Rilke afirma ainda que "Denn man begann die Natur erst zu begreifen, als man sie nichtmehr begriff; als man fühlte, daß sie das Andere war, das Teilnahmslose, das keine Sinne hat uns aufzunehmen, da war man erst aus ihr herausgetreten; einsam, aus einer einsamen Welt."147 (RILKE, 1996, p. 211-212). Rilke afirma que o artista que desejar retratar a natureza deve percebê-la objetivamente como “[...] eine große vorhandene Wirklichkeit."148 (RILKE, 1996, p. 212), ou seja, sem tirar conclusões a respeito dela, sem procurar por significados ocultos nela. E termina o texto dizendo que pintores - que ele não nomeia - conseguiram, ao longo do tempo, começar a retratar paisagens dessa maneira, abandonando gradativamente o caráter subjetivo. Surgiram assim paisagens vazias, em que nada acontecia, e quando a figura humana voltava a ser inserida nessas paisagens, também ela recebia o mesmo tratamento objetivo e distanciado:

In diesem Aufwachsen der Landschafts-Kunst zu einem langsamen LandschaftWerden der Welt liegt eine weite menschliche Entwicklung. Der Inhalt dieser Bilder, der so absichtslos aus Schauen und Arbeit entsprang, spricht uns davon, daß eine Zukunft begonnen hat mitten in unserer Zeit: daß der Mensch nichtmehr der Gesellige ist, der unter seinesgleichen im Gleichgewicht geht, und auch derjenige nichtmehr, um dessentwillen Abend und Morgen wird und Nähe und Ferne. Daß er unter die Dinge gestellt ist wie ein Ding [...]. ${ }^{149}$ (RILKE, 1996, p. 212-213).

Alcançar essa objetividade e distância em relação à paisagem era, no ponto de vista de Rilke, um aprendizado maior para as pessoas, na medida em que também tinha a ensinar sobre a vida em sua época: não existia equilíbrio social, não existia comunidade. $\mathrm{O}$ aprendizado do olhar objetivo permitia perceber que a existência humana era nada mais que uma coisa entre todas as outras coisas existentes no mundo.

\footnotetext{
147 “Então começou-se a compreender a natureza quando não se podia mais compreendê-la; quando se sentia que ela era o outro, o impassível, que não havia sentido em nos incluirmos, pois se havia dado um passo para fora dela; solitário, vindo de um mundo solitário.” (Tradução nossa).

148 “[...] uma grande realidade pré-existente.” (Tradução nossa).

149 "Nesse crescimento da paisagem-arte em um lento tornar-se-paisagem do mundo está um amplo desenvolvimento humano. O conteúdo dessa imagem, que emanou olhar e trabalho tão sem intenção, nos diz que um futuro começou em meio a nosso tempo: que o ser humano não é mais o ser social, que entre seus semelhantes encontra equilíbrio, e também não é mais aquele, de cuja vontade vem a noite e o dia e o próximo e o longe. Que ele está entre as coisas, e é como uma coisa [...].” (Tradução nossa).
} 
Se em "Von der Landschaft" Rilke parece não ver contradição quando fala que Leonardo da Vinci pôde pintar paisagens que eram ao mesmo tempo confissões íntimas (de sua subjetividade), capazes de evocar sentimento, e representações objetivas da natureza, no final do texto seu argumento é de que o olhar objetivo e o abandono da subjetividade eram a maneira mais apropriada de retratar a natureza em seu tempo. É preciso lembrar que "Von der Landschaft" não chegou a ser publicado na época - e a versão final da introdução da monografia Worpswede (já mencionada neste capítulo) difere bastante dessa primeira versão. Ainda assim, é importante ressaltar que esse texto foi escrito no início de 1902 - portanto meses antes de Rilke viajar a Paris e conhecer Rodin pessoalmente ou de ter contato com as pinturas de Cézanne -, mas já nesse momento começava a elaborar a premissa do olhar objetivo, segundo a qual o artista deve reproduzir na arte aquilo que vê objetivamente. As passagens de textos estéticos anteriores à primeira viagem de Rilke para a França, discutidas até aqui, revelam que o encontro com Rodin não marca (apesar de Rilke dar a entender que sim, nas cartas que enviou ao escultor, mencionadas no início deste capítulo) uma ruptura total com as reflexões sobre arte que Rilke vinha desenvolvendo desde o final do século XIX. Ao contrário, as experiências parisienses parecem ter contribuído para aprofundar e dar contornos mais precisos a uma reflexão sobre o olhar que já vinha sendo construída. E, talvez o que tenha sido mais significativo, as experiências parisienses permitiram a Rilke entrar em contato com artistas contemporâneos que realizaram em seus trabalhos a premissa do olhar objetivo.

\subsection{Auguste Rodin}

Quando foi a Paris pela primeira vez em 1902, Rilke tinha 27 anos e Rodin, 62. O escultor, que na juventude havia tentado por três vezes ingressar na École des Beaux-Arts sem sucesso e tido trabalhos rejeitados por salões - o retrato L'Homme au Nez Cassé, por exemplo, foi impedido de ser exibido em um salão de 1864 -, naquela altura, era famoso. Sua

primeira grande escultura a ser aceita em um salão, L'Âge d'Airain, de 1876, causou controvérsia no meio da arte e Rodin foi alvo de diferentes acusações. Ainda assim, nos anos subsequentes, passou a receber apoio de outros artistas, a expor trabalhos regularmente e a receber encomendas para monumentos públicos. De acordo com o artista e estudioso britânico William Tucker, "Rodin's public reputation soon overhauled that of his radical 
contemporaries in painting, until by 1900 he was probably the most famous artist in the world." 150 (TUCKER, 1977, p. 16).

Rilke começa a monografia ${ }^{151}$ tratando precisamente da fama do escultor: "Rodin war einsam vor seinem Ruhme. Und der Ruhm, der kam, hat ihn vielleicht noch einsamer gemacht. Denn Ruhm ist schließlich nur der Inbegriff aller Mißverständnisse, die sich um einen neuen Namen sammeln."152 (RILKE, 1996, p. 405). No entanto, antes da fama e dos mal-entendidos que a acompanham, há outra característica de Rodin sendo ressaltada pelo poeta, uma qualidade que é própria do escultor, e não atribuída a ele: sua solidão. Quanto aos mal-entendidos, Rilke afirma que não pretende desfazê-los, e justifica:

Es sind ihrer sehr viele um Rodin, und es wäre eine lange und mühsame Aufgabe, sie aufzuklären. Es ist auch nicht nötig; sie stehen um den Namen, nicht um das Werk, das weit über dieses Namens Klang und Rand hinausgewachsen und namenlos geworden ist, wie eine Ebene namenlos ist, oder ein Meer, das nur auf der Karte einen Namen hat, in den Büchern und bei den Menschen, in Wirklichkeit aber nur Weite ist, Bewegung und Tiefe. ${ }^{153}$ (RILKE, 1996, p. 405).

Esses dois pequenos parágrafos iniciais já adiantam o que o leitor pode esperar encontrar na monografia: utilizando uma linguagem poética rica em metáforas, Rilke se preocupa muito pouco em trazer fatos concretos sobre a vida de Rodin; sua atenção está voltada para a obra, e dados biográficos o interessam apenas na medida em que o ajudem a vislumbrar quais caminhos o escultor teria percorrido para chegar às suas técnicas inovadoras e criar suas esculturas. Isso porque, na visão de Rilke, a obra de Rodin tornou-se maior do que ele, independente dele: a obra se projeta para além da história do indivíduo que a criou, sobre o qual, ademais, pouco ou nada se sabe.

150 "A reputação pública de Rodin rapidamente ultrapassou a de seus contemporâneos radicais na pintura, até que, por volta de 1900, ele era provavelmente o artista mais famoso no mundo.” (Tradução nossa).

${ }^{151} \mathrm{O}$ texto sobre Rodin é tratado pela fortuna crítica como "Monographie", ou "Rodin-Monographie" (o texto sobre os artistas de Worpswede também é chamado de "Monographie"). Os comentários do editor dos escritos estéticos reunidos de Rilke dão a entender que esse termo foi usado por Richard Muther quando encomendou o ensaio a Rilke (cf. NALEWSKI, 1996, p. 929-939).

152 "Rodin era um homem solitário antes de se tornar famoso. E a fama de que desfrutou depois talvez o tenha tornado ainda mais solitário. Pois a fama, afinal, é apenas a essência, a síntese de todos os mal-entendidos que cercam um novo nome.” (RILKE, 2003, p. 15). A tradução do ensaio Auguste Rodin citada nesta dissertação é de Marion Fleisher.

153 "Existem muitos destes equívocos em torno de Rodin, e seria uma tarefa longa e estafante esclarecê-los. Ademais, é desnecessário fazê-lo; estas equivocações dizem respeito ao nome, e não à obra, que transcendeu amplamente a projeção deste nome e se tornou anônima, assim como uma planície ou um mar são anônimos, cujos nomes existem apenas no mapa, nos livros e nas menções dos seres humanos, mas na realidade constituem apenas amplidão, movimento e profundidade.” (RILKE, 2003, p. 15). 
Na monografia, Rilke parece tentar manter o escultor como um desconhecido para seu leitor, trazendo à tona apenas alguns poucos aspectos de sua personalidade que, em sua visão, seriam relevantes para compreender seu trabalho. Na palestra de 1905, Rilke pede à plateia que procure esquecer o nome da pessoa sobre quem ele irá tratar (cf. RILKE, 1996, p. 454). De acordo com Hoffmann, o poeta inicia sua apresentação desse modo porque seu interesse não está em apresentar informações sobre a vida do escultor, mas sim “[...] in der Vermittlung einer ästhetisch-anthropologischen Grundhaltung, die Rodin beispielhaft verkörpert und die Rilke zur Orientierung und Nachahmung empfiehlt."154 (HOFFMANN, 2010, p. 544). Rodin é tratado como um exemplo anônimo - "ein namenloses Beispiel" (RILKE apud HOFFMANN, 2010, p. 544) - de uma determinada atitude artística e um modo de criação para a representação moderna que, estes sim, Rilke desejava explicar a seus ouvintes. Uma abordagem semelhante vale para a monografia de 1902. Nela, embora não suprima o nome de Rodin, Rilke o descreve da mesma maneira como descreve suas esculturas: procurando enxergar a motivação que existe por trás de suas ações, dos gestos e expressões, e parece fazer esse exercício especulativo não só para tentar entender como ele conseguiu realizar uma obra de tamanha grandeza. A imagem do escultor construída por Rilke ao longo da monografia é a de um homem que renunciou à própria vida para dedicar-se inteiramente à criação artística, ou seja, um homem que recusou uma vida mundana e previsível e construiu para si outra, na qual só havia espaço para a arte. Na narrativa de Rilke, o homem Rodin não aparece: o poeta não trata das relações com colegas artistas, familiares, mestres ou pupilos, e o leitor poderia ser levado a acreditar que Rodin apenas se relacionava com modelos, através da observação, e com o barro, o bronze e o mármore.

Com efeito, Rodin era essencialmente um autodidata ${ }^{155}$ e um completo desconhecido para o público até começar a participar de exposições. Quando expôs L'Âge d'Airain pela primeira vez em 1977, parte do frisson suscitado pela obra foi o fato de que "[...] it was a sculpture apparently without antecedent, by an artist whose preparation for envisaged

154 “[...] na mediação de uma atitude estética-antropológica que Rodin incorpora de modo paradigmático e que Rilke recomenda como orientação e imitação.” (Tradução nossa).

155 "In his reading, his ambition - confirmed by a visit to Rome and Florence in 1875 - his handling of clay and his treatment of the figure, he was thus virtually self-educated. His contacts were with fellow craftsmen and academic 'superiors'; the two older sculptors of talent and independence whose classes he attended, Barye and Carpeaux, had no exchange with him.” (TUCKER, 1977, p. 17). [“Em suas leituras, sua ambição - confirmada por uma visita a Roma e a Florença em 1875 - seu manuseio da argila e seu tratamento da figura, ele era praticamente autodidata. Seus contatos eram com colegas artesãos e 'superiores' acadêmicos; os dois escultores mais velhos que possuíam talento e independência cujas aulas ele frequentou, Barye e Carpeaux, não tiveram nenhuma troca com ele." (Tradução nossa).] 
greatness, for a new role for sculpture itself, had been utterly private, isolated and obscure."156 (TUCKER, 1977, p. 17). Tendo em vista esse desenvolvimento isolado e anônimo, Rilke reforça que qualquer história que venha a ser contada sobre a infância de Rodin terá sido inventada, e especula: provavelmente, se dirá que ele foi uma criança que se esquecia dos afazeres mundanos enquanto explorava diferentes materiais, conduzido gradativamente por “[...] ein inneres Gefühl [...]." ${ }^{157}$ a buscar “[...] die Gnade der großen Dinge [...]."158 (cf. RILKE, 1996, p. 406). Nesse ponto do texto, Rilke retira o foco do artista para discorrer sobre o que seria "die Gnade der großen Dinge": a arte aparece aqui como o recurso mais importante de representação do mundo e do homem. Rilke começa a sintetizar em poucas páginas o percurso da escultura ao longo do tempo. Sem trazer fatos, datas e nomes, ele indica algumas das características estéticas de diferentes períodos, da Antiguidade ao Renascimento - após o qual, segundo ele, a arte escultórica, “[...] die noch in der Furcht einer großen Vergangenheit zögerte [...]." ${ }^{159}$ (RILKE, 1996, p. 408), ainda não havia acompanhado as mudanças que ocorriam no mundo.

A breve cronologia da arte escultórica traçada por Rilke culmina em um momento no qual a escultura “[...] mußte einer Zeit helfen können, deren Qual es war, daß fast alle ihre Konflikte im Unsichtbaren lagen. Ihre Sprache war der Körper. Und diesen Körper, wann hatte man ihn zuletzt gesehen?"160 (RILKE, 1996, p. 408). Embora o poeta não utilize expressamente o termo Modernidade, sua descrição deixa claro que o tempo de que está tratando é ela - a época do escultor, e também sua. Se a Modernidade é definida como - nas palavras de Baudelaire - “[...] o transitório, o fugidio, o contingente [...].” (BAUDELAIRE, 2010, p. 35), pode-se pensar que os "conflitos invisíveis" de que Rilke fala são uma consequência psicológica da vida nas grandes cidades, definida por Georg Simmel como “[...] a intensificação da vida nervosa, que resulta da mudança rápida e ininterrupta de impressões interiores e exteriores." (SIMMEL, 2005, p. 577-578, grifo do autor). O crescimento das

\footnotetext{
156 “[...] era uma escultura aparentemente sem antecedente, feita por um artista cuja preparação para grandeza esperada, para um novo papel da própria escultura, havia sido essencialmente privado, isolado e obscuro." (Tradução nossa).

157 “[...] uma voz interior [...].” (RILKE, 2003, p. 17).

158 “[...] a graça divina das grandes coisas [...].” (RILKE, 2003, p. 17).

159 “[...] que ainda hesitavam dominadas pelo medo de um grande passado [...].” (RILKE, 2003, p. 20).

160 “....] precisava ser capaz de ajudar uma época cujo sofrimento consistia no fato de que quase todos os seus conflitos se concentravam no invisível. Sua linguagem era o corpo. E este corpo - quando ele tinha sido visto pela última vez?" (RILKE, 2003, p. 20).
} 
cidades e a consequente mudança da vida psíquica se refletiam também em transformações nos corpos das pessoas. Rilke mostra que nessa época havia surgido uma lacuna: todas as artes haviam se renovado, exceto a escultura (cf. RILKE, 1996, p. 408). Foi com o problema deixado por essa lacuna que Rodin havia se deparado: como representar o corpo do homem moderno, constantemente atravessado pela agitação da cidade? Como os conflitos psíquicos da vida moderna transparecem nos gestos?

Essa lacuna na arte escultórica da Modernidade demandava que se voltasse o olhar para representar o que ainda não havia sido visto, notado, para os gestos ainda não identificados do sujeito moderno. E por causa desse caráter inédito, o artista que se dispusesse a fazer essas representações, teria também que buscar um novo meio de fazê-las: "Hier war eine Aufgabe, groß wie die Welt." "161 (RILKE, 1996, p. 409). Rilke exalta o tamanho da tarefa como havia exaltado, nos primeiros parágrafos, a grandeza da obra de Rodin, recorrendo a metáforas da natureza. Nesse ponto, Rilke retoma a figura do artista e articula o texto de forma a revelar sutilmente uma característica chave de Rodin, que irá tratar com mais detalhes no decorrer do livro: sua obstinação. Rodin surge não como alguém que estivesse, a princípio, à altura da tarefa diante de si, ao contrário: na descrição de Rilke, parece modesto e humilde demais para essa empreitada. Mas, segundo Rilke, é justamente nessa humildade que residia sua força, pois ele se pôs a trabalhar imediatamente: "Und der vor ihr stand und sie sah, war ein Unbekannter, dessen Hände nach Brot gingen, in Dunkelheit. Er war ganz allein [...]. Aber dieser junge Mensch [...] war ein Träumer, dem der Traum in die Hände stieg, und er begann gleich mit seiner Verwirklichung."162 (RILKE, 1996, p. 409).

Para apreender os gestos do homem moderno, era preciso primeiro conhecer bem o corpo humano: "Rodin wußte, daß es zunächst auf eine unfehlbare Kenntnis des menschlichen Körpers ankam." 163 (RILKE, 1996, p. 411). A partir do estudo do corpo, “[...] hatte Rodin das Grundelement seiner Kunst entdeckt, gleichsam die Zelle seiner Welt. Das war die Fläche [...]."164 (RILKE, 1996, p. 411): Rodin chegava assim a um conceito fundamental de sua obra,

\footnotetext{
161 "Aqui havia uma tarefa grande como o mundo." (RILKE, 2003, p. 21).

162 "E aquele que diante dela se encontrava e a via era um desconhecido, cujas mãos buscavam trabalho, caminhando no escuro. Ele estava completamente sozinho [...]. Mas este jovem [...] era um sonhador cujos sonhos impregnavam as suas mãos e ele imediatamente começou com a sua realização.” (RILKE, 2003, p. 21).

163 "Rodin sabia que tudo dependia, sobretudo, de um exato conhecimento do corpo humano." (RILKE, 2003, p. 23).

164 “[...] Rodin havia encontrado o elemento fundamental de sua arte, por assim dizer a célula do seu mundo. Era a superfície [...].” (RILKE, 2003, p. 24).
} 
o da escultura como interação de superfícies, e, a partir dele, a invenção de uma nova técnica de modelado. Com isso, Rodin iniciou seu trabalho mais relevante: com a nova modelagem da superfície, ele teria encontrado a chave para criar figuras que pareciam estar vivas, subvertendo todos os princípios formais da escultura:

\begin{abstract}
Nun erst waren alle die herkömmlichen Begriffe der Plastik für ihn wertlos geworden. Es gab weder Pose, noch Gruppe, noch Komposition. Es gab nur unzählbar viele lebendige Flächen, es gab nur Leben, und das Ausdrucksmittel, das er sich gefunden hatte, ging gerade auf dieses Leben zu." ${ }^{.65}$ (RILKE, 1996, p. 412).
\end{abstract}

Está em questão aqui não só a elaboração de um método de trabalho, mas também a intensificação de um aprendizado essencial, sem o qual ela talvez não tivesse ocorrido: o olhar. De acordo com Rilke, "Rodin erfaßte das Leben, das überall war, wohin er sah. Er erfaßte es, an den kleinsten Stellen, er beobachtete es, er ging ihm nach. [...] Da war kein Teil des Körpers unbedeutend oder gering: er lebte." 166 (RILKE, 1996, p. 412). Para modelar a escultura de forma que esta parecesse viva, era preciso perceber os corpos como superfícies. Era preciso notar os côncavos do corpo e ressaltá-los na escultura para que os corpos parecessem flexíveis, tensionados, animados por uma força interior. Nos diálogos com Paul Gsell, de $1911^{167}$, Rodin descreve sua técnica de modelado de maneira muito semelhante, e contando ainda a seu interlocutor que sua "ciência do modelado" ("science du modelé") lhe foi transmitida por um antigo colega de trabalho, Constant. O ensinamento foi o de modelar as formas tratando-as como volumes, projetando partes das figuras na direção do artista/espectador para criar a impressão de profundidade: as superfícies são tratadas “[...] somente como extremidade de um volume - como a ponta, a maior ou menor, que se volta para você." (RODIN, 1990, p. 46). Segundo Rodin, o "belo modelado" ("beau modelé") cria nuances de luz e sombra nos relevos da escultura, produzindo um efeito de jogos de cor entre

\footnotetext{
165 "Somente agora todos os conceitos tradicionais [da escultura] tornaram-se inúteis para ele. Não havia nem a pose, nem o grupo, nem a composição. Havia apenas incontáveis superfícies vivas, havia apenas vida, e o recurso expressivo que ele havia encontrado para a sua arte ia precisamente ao encontro desta vida." (RILKE, 2003, p. 24). [Nota: Marion Fleisher traduz o termo "Plastik" para "arte plástica". Consideramos essa escolha equivocada e, por esse motivo, deixamos entre colchetes na citação a tradução do termo que nos parece mais apropriada dada a especificidade do contexto tratado por Rilke.]

166 "Rodin agarrava a vida, que se encontrava em toda parte, para onde quer que volvesse os olhos. [...] Nesta vida nenhuma parte do corpo era insignificante ou inferior: ele vivia." (RILKE, 2003, p. 24-25).

167 Apesar de as conversas com Paul Gsell terem sido compiladas quase uma década depois de Rilke ter escrito sua monografia sobre o escultor francês, tendo e vista que em 1902 Rodin era um escultor maduro e que as obras mencionadas tanto na monografia quanto nas conversas já haviam sido realizadas, consideramos aqui que as considerações que Rodin fez em 1911 de seus métodos de trabalho eram pertinentes também em 1902, uma vez que naquela época sua poética já estava consolidada.
} 
preto e branco; o trabalho do escultor, por este aspecto, seria o mesmo do colorista, e seria essencial para criar a ilusão de vida na obra (cf. RODIN, 1990, p. 48).

Rodin modelava a superfície como se ela fosse o topo do volume do corpo, e a matéria era tratada não como algo morto, inerte, mas como algo que possuísse energia própria. Michaela Kopp explica que as técnicas tradicionais de modelado tratavam a argila ou o mármore como matéria inerte à qual seria imposta uma forma ativa por meio de métodos aditivos ou redutivos. A escultura era assim entendida como matéria moldada, que representava principalmente modelos já pré-estabelecidos de heróis e deuses e produzia obras que eram fundamentalmente alheias ao seu contexto (cf. KOPP, 1999, p. 144-145). Para Rodin, o material estava sujeito à expressão do artista; ele entendia a escultura como resultado de um processo de modelar, estruturar e combinar diferentes planos, que não necessariamente correspondiam à anatomia humana, mas que eram combinados de tal maneira que, quando capturados pelo olhar do observador, provocam a impressão de corpo vivo. "Flächen modellieren bedeutet Schnitte machen, bauen und fügen, um spannungsreiche Beziehungen unter ihnen herzustellen." 168 (KOPP, 1999, p. 144). Com base nessa concepção da modelagem, aspectos da interioridade do modelo também estariam representados, “[...] ob seelisch, gestig oder gedanklich [...]."169, eles são realizados no corpo e por isso afetam a superfície (cf. KOPP, 1999, p. 145).

William Tucker afirma que a polêmica em torno de L'Âge d'Airain (que Rilke trata pelo título Mannes der ersten Zeiten ${ }^{170}$ ) foi suscitada, em parte, pelo fato de que a superfície da escultura trazia as marcas do trabalho manual do artista na modelagem da argila. Segundo o estudioso, na época, a escultura acadêmica era feita principalmente em mármore, planejada pelos artistas de acordo com poses e temas que já haviam se tornado padrões, e quase sempre executada por assistentes ${ }^{171}$. A evidência dupla na superfície de L'Aige d'Airain, da

\footnotetext{
168 "Modelar superfícies significava fazer cortes, construir e combinar, para produzir relações de tensão entre elas.” (Tradução nossa).

169 “[...] seja emocional, espiritual ou mental [...].” (Tradução nossa).

${ }^{170}$ Homem dos tempos primevos (cf. RILKE, 2003, p. 29).
}

171 "The sculptor's role in this process was analogous to that of a modern film diretor. Academic sculpture by the 1870s had in effect become an industry, commercialized and mechanized to a remarkable extent. The sheer quantity of sculpture produced in the nineteenth century, the degree of craftsmanship, the advances in production methods, were in inverse proportion to creativity, to artistic quality. If one sculpture could be said to have reversed this situation, to have returned the responsibility for sculpture to sculptors, it is the Age of Bronze." (TUCKER, 1977, p. 24-25). [“O papel do escultor nesse processo era análogo ao do moderno diretor de cinema. A escultura acadêmica nos anos 1870 havia de fato se tornado uma indústria, comercializada e mecanizada a um ponto notável. A vasta quantidade de esculturas produzidas no século dezenove, o grau de competência e os 
materialidade da argila e da mão do artista, revelava o comprometimento de Rodin em pensar e executar ele mesmo todas as partes e etapas da criação da escultura: "[...] its conception, its form, its size, its material, its finish, its relation to the spectator." 172 (TUCKER, 1977, p. 24, grifo do autor). O fato de nessa obra a estrutura da figura representada coincidir com a estrutura da escultura também provocou um grande impacto: "The sculpture is the figure, the figure is the sculpture. [...] Here was a sculpture stripped down to its essentials - no accessories, no ornament, no detail, no story, no message." ${ }^{173}$ (TUCKER, 1977, p. 25, grifo do autor). A figura modelada por Rodin não só não possuía adornos, ela também não estava presa a uma representação engessada, por exemplo, uma alegoria, como era comumente feito nos ateliês da época. A obra era, por esse viés, autônoma, e Rilke também havia percebido essa característica: "Nie ist ein Stoff bei Rodin an ein Kunst-Ding gebunden, wie ein Tier an einen Baum. Er lebt irgendwo in der Nähe des Dinges und lebt von ihm, etwa wie der Kustos einer Sammlung."174 (RILKE, 1996, p. 430). Com L'Âge d'Airain, Rodin foi acusado de apresentar uma escultura inacabada, e de a ter feito usando o molde de um modelo: "The contradictory character of these charges indicates that Rodin had achieved a new and far higher order of naturalism, in terms of an illusion of reality, of the living model, with a sculpture whose surface is, in academic terms, 'unfinished'."175 (TUCKER, 1977, p. 25). De acordo com Tucker, o uso que Rodin fazia da argila, criando superfícies complexas a partir de um material totalmente moldável, representava uma ruptura violenta com seus predecessores (cf. TUCKER, 1977, p. 19-20), e a unidade da superfície com a estrutura da obra L'Âge d'Airain é o que a distingue das esculturas anteriores: "[...] every inch of the surface is considered, worked on, invented; every inch is equally and differently expressive; expression is diffused from facial expression, from depicted gesture and muscular contortion, into the

avanços nos métodos de produção eram inversamente proporcionais à criatividade, à qualidade artística. Se há uma escultura que se pode dizer que reverteu essa situação, que devolveu a responsabilidade pela escultura aos escultores, foi A Idade do Bronze." (Tradução nossa).]

172 “[...] sua concepção, sua forma, seu tamanho, seu material, seu acabamento, sua relação com o espectador." (Tradução nossa).

173 "A escultura é a figura, a figura é a escultura. [...] Aqui estava uma escultura reduzida ao essencial - sem acessórios, sem ornamentos, sem detalhes, sem história, sem mensagem.” (Tradução nossa).

174 "Na obra de Rodin jamais um tema ficou preso a um objeto-arte como um animal amarrado a uma árvore. O tema vive em alguma parte nas proximidades do objeto, e dele vive, à semelhança do bibliotecário de uma coleção.” (RILKE, 2003, p. 50).

175 “O caráter contraditório dessas acusações indica que Rodin havia alcançado uma ordem muito mais alta de naturalismo, em termos de criar uma ilusão de realidade, de modelo vivo, com uma escultura cuja superfície é, em termos acadêmicos, "inacabada'." (Tradução nossa). 
animation of the entire surface."176 (TUCKER, 1977, p. 27). A essas duas características juntas, a nova modelagem e a estruturação da figura, remontaria o caráter moderno da obra de Rodin, ou seja: aos processos de feitura (“making”) da obra (cf. TUCKER, 1977, p, 30).

Rilke reconhece a materialização desses processos em uma das obras anteriores de Rodin, o busto Homme au nez cassé, rejeitado pelo Salão de 1864. "Man begreift das sehr gut, denn man fühlt, daß in diesem Werke Rodins Art schon ganz ausgereift war, ganz vollendet und sicher [...]." ${ }^{177}$ (RILKE, 1996, p. 415). Todos os detalhes contidos nessa peça teriam sido cuidadosamente feitos a partir da percepção que o escultor teve do rosto do homem que posou para ele, das marcas que as constantes mudanças, acontecimentos e preocupações que ocorreram ao longo da vida haviam feito nesse rosto, e dessas marcas seria possível supor partes da história e das emoções do retratado ${ }^{178}$. Apesar de ser um retrato, o rosto desse homem possui movimento, conferido pelas linhas, pela assimetria, pelos contrastes de luz e sombra produzidos pelo relevo, elementos que sugerem as mudanças de expressões e o fato de que esse rosto continua a ser transformado pela vida ${ }^{179}$. "Man muß sich mühsam erinnern, daß alles das auf dem Raume eines Gesichtes steht, so viel schweres, namenloses Leben erhebt

176 “[...] cada centímetro da superfície é considerado, trabalhado, inventado; cada centímetro é igualmente e diferentemente expressivo; a expressão se difunde da expressão facial, do gesto representado e da torsão muscular, para animar toda a superfície." (Tradução nossa).

177 “Tal fato é perfeitamente compreensível, pois sentimos que nesta obra a arte de Rodin já estava inteiramente amadurecida, aperfeiçoada e segura de si mesma.” (RILKE, 2003, p. 29).

178 "Man glaubt zu fühlen, wie einige von diesen Furchen früher kamen, andere später, wie zwischen dem und jenem Riß, der durch die Züge geht, Jahre liegen, bange Jahre, man weiß, daß von den Zeichen dieses Gesichtes einige langsam eingeschrieben wurden, gleichsam zögernd, daß andere erst leise vorgezeichnet waren und von einer Gewohnheit oder einem Gedanken, der immer wiederkam, nachgezogen wurden, und man erkennt jene scharfen Scharten, die in einer Nacht entstanden sein mußten, wie vom Schnabel eines Vogels hineingehackt in die überwache Stirne eines Schlaflosen." (RILKE, 1996, p. 416). ["Parece-nos perceber que algumas dessas rugas apareceram mais cedo, outras mais tarde, que entre esta e aquela greta que perpassa o rosto transcorreram anos, anos angustiados. Sabemos que alguns dos sinais deste rosto nele foram inscritos lentamente, como que hesitantes, que outros foram primeiramente esboçados suavemente e depois demarcados por um hábito ou um pensamento que sempre retornava, e reconhecemos as mossas contundentes que devem ter sua origem em alguma noite, como se houvessem sido provocadas pelas bicadas de uma ave na mente alerta de um homem insone." (RILKE, 2003, p. 30-31).]

179 "Man fühlt, was Rodin anregte, diesen Kopf zu formen, [...] es war die Fülle von Leben, die in diesen Zügen versammelt war; es war der Umstand, daß es auf diesem Gesichte gar keine symmetrischen Flächen gab, daß nichts sich wiederholte, daß keine Stelle leer geblieben war, stumm oder gleichgültig. Dieses Gesicht war nicht vom Leben berührt worden, es war um und um davon angetan, als hätte eine unerbittliche Hand es in das Schicksal hineingehalten wie in die Wirbel eines waschenden, nagenden Wassers." (RILKE, 1996, p. 415-416). ["Sente-se que o que compeliu Rodin a formar esta cabeça [...] era a plenitude de vida que se concentrava nestes traços; era o fato de que neste rosto não havia superfícies simétricas, que nada se repetia, que nenhuma parte ficara vazia, muda ou indiferente. Este rosto não tinha sido tocado pela vida, ele era inteiramente vida, como se uma mão implacável o tivesse mergulhado no destino como que em turbilhões de água deletéria, corrosiva." (RILKE, 2003, p. 30).] 
sich aus diesem Werke." ${ }^{180}$ (RILKE, 1996, p. 416). Utilizando esses artifícios, Rodin teria conseguido concentrar a vida desse homem em uma única parte de seu corpo, e Rilke ressaltou diversas vezes essa capacidade de síntese. Se nos retratos talvez não espantasse que o escultor conseguisse concentrar tantos elementos, outras peças, também fragmentos, como mãos e torsos - a princípio menos reveladores a respeito da vida de uma pessoa - eram modelados por Rodin de maneira que, de acordo com Rilke, pareciam possuir vida a tal ponto que adquiriam autonomia e se tornavam independentes do restante do corpo (cf. RILKE, 1996, p. 422).

Essa capacidade de concentração e síntese remontaria à atenção dada por Rodin ao movimento e ao gesto. "Es gab nur Bewegung in der Natur [...]." ${ }^{\prime 81}$ (RILKE, 1996, p. 417): uma arte que se propusesse representar a vida deveria necessariamente estar atenta ao fato de que a vida é constante movimento e transformação. Rilke salienta que não se trata de um movimento contrário à essência da escultura, mas sim que “[...] es war nur die Bewegung, die nicht zu Ende geht, die nicht von anderen im Gleichgewicht gehalten wird, die hinausweist über die Grenzen des Dinges."182 (RILKE, 1996, p. 417). A escultura acadêmica reproduzia poses pré-estabelecidas e produzia com isso figuras estáticas, congeladas, que podiam representar alegorias, mas não corpos vivos. Rodin, ao contrário, acreditou que os movimentos espontâneos dos seus modelos, mesmo os mais sutis, poderiam expressar muito mais do que as poses cuidadosamente montadas. Assim, registrou gestos outrora negligenciados e os reproduziu plasticamente, conectando-os uns aos outros para imprimir às suas figuras algo da dinâmica da vida humana (cf. RILKE, 1996, p. 432). Esses gestos iam além das ações mundanas. Quando escreve sobre La Porte de l'Enfer (1880-1917), Rilke afirma que o escultor soube dar aos corpos que compõem o conjunto movimentos provenientes de agitações interiores: "[...] die Gebärden der Menschheit, die ihren Sinn nicht finden kann, ungeduldiger geworden, nervöser, rascher und hastiger." ${ }^{183}$ (RILKE, 1996, p.426).

\footnotetext{
180 “Com muito esforço é preciso lembrar que tudo isto está escrito no espaço de um rosto, que uma vida tão árdua, anônima, emerge desta obra.” (RILKE, 2003, p. 31).

181 "Na natureza havia somente movimento." (RILKE, 2003, p. 32).

182 “[...] era apenas o movimento que não finda, que não é contrabalançado por outros, e transpõe os limites do objeto.” (RILKE, 2003, p. 32).

183 “[...] os gestos da humanidade que não consegue encontrar o seu sentido tornaram-se mais impacientes, nervosos, apressados e bruscos." (RILKE, 2003, p. 45).
} 
Com a intenção de criar a ilusão de vida, Rodin desenvolveu sua técnica para recriar o movimento na escultura. "Primeiro, observe que o movimento é a transição de uma atitude para outra." (RODIN, 1990, p. 54, grifo do autor). Apontando para fotografias de corpos em movimento, Rodin ressalta que uma imagem capturada do movimento mostra apenas um momento dessa transição: a fotografia congela a ação, tornando o corpo estático. Logo, uma escultura que se propusesse a imitar o movimento não deveria recorrer ao mesmo artifício, reproduzindo uma das posições do corpo no decorrer do deslocamento, pois pareceria inerte. O que faz Rodin é amalgamar diferentes momentos do corpo ao longo do movimento em uma única figura, criando posições impossíveis, mas, ao mesmo tempo, que representam a passagem de uma posição à outra. "O escultor obriga, pode-se dizer, o espectador a acompanhar a progressão de um ato através de um personagem.” (RODIN, 1990, p. 56), ou ainda: o artista impõe ao observador que percorra toda a extensão da escultura para apreender a ação que ela representa.

A ilusão de que a escultura tem vida, é feita de carne e se movimenta, é provocada pelos artifícios a que Rodin recorria para construí-las, mas ela se efetiva de fato no olhar do espectador. No caminho que o olho percorre por cada uma das diferentes partes da escultura, à medida que a circunda, a obra, composta por fragmentos, ganha unidade quando o espectador tem a impressão de estar diante de uma pessoa, não de uma estátua de bronze. Embora a escultura possa mostrar uma posição do corpo que seja impossível ou improvável na realidade, por causa da impressão de movimento que provoca no observador, ela é visualmente realista. Para atingir esse objetivo, Rodin utilizava métodos de estudo e trabalho diferentes dos demais escultores de sua época. Ao invés de orientar rigorosamente os modelos a fazerem determinadas poses, Rodin observava seus modelos se movimentarem à vontade, e procurava capturar a espontaneidade de seus gestos: "Extraio da vida os movimentos que observo, mas não sou eu quem os impõe. [...] pois quero representar apenas o que a realidade espontaneamente me oferece.” (RODIN, 1990, p. 21). A observação atenta e precisa aparece então como peça chave para a compreensão de suas obras: ela foi importante para que o artista percebesse as nuances dos movimentos feitos com naturalidade pelos modelos, para que ele desenvolvesse técnicas de modelagem e composição que representassem de forma convincente essas nuances, e para que o espectador apreenda a obra final de maneira que vá ao encontro dos objetivos do artista.

Os corpos fragmentados, amalgamados, de gestos erráticos, nervosos e apressados corresponderiam aos corpos e aos movimentos dos sujeitos modernos, que vivem 
atravessados pela intensidade e variedade de estímulos do seu ambiente. Rodin tinha dado forma às agitações invisíveis que se operavam no íntimo das pessoas, combinando sua capacidade de observação, seu conhecimento plástico e sua habilidade de modelagem para criar técnicas que produzissem a impressão de movimento, de vida. O olhar era um procedimento fundamental, tanto para capturar da vida os elementos que seriam transpostos para a escultura, quanto para entender de que maneira os movimentos poderiam ser simulados na escultura, como Rilke destacou reiteradamente em seu ensaio.

Na descrição de Rilke, Rodin apenas reproduz na argila aquilo que vê diante de si, nada é inventado: "Er gab seiner Phantasie nicht Raum; er erfand nicht."184 (RILKE, 1996, p. 433). Assim como não fantasiava, também não permitia que qualquer pré-julgamento afetasse o modo como observava seus modelos: "Er giebt nicht dem ersten Eindruck recht und nicht dem zweiten und von allen nächsten keinem. Er beobachtet und notiert."185 (RILKE, 1996, p. 436); e Rodin não permite sequer que seu modelo revele qualquer informação a respeito de si mesmo que já não esteja dada em seu próprio corpo: "Er läßt sich nichts von dem Betreffenden erzählen, er will nichts wissen als was er sieht. Aber er sieht alles."186 (RILKE, 1996, p. 436). O trabalho da visão desempenha um papel importante no processo de criação escultórica: o olhar treinado do artista registra apenas o que é relevante para a representação do corpo e do movimento; ele não faz perguntas nem tira conclusões. Segundo Rilke, quando Rodin fazia anotações do que observava, ele desenhava com traços rápidos ou modelava agilmente na argila os gestos dos modelos, quase sem tirar os olhos deles, procurando capturar a força expressiva da espontaneidade (cf. RILKE, 1996, p. 432). E, quando não tinha os modelos presentes, recorria à sua memória: "Seine Erinnerung ist weit und geräumig; die Eindrücke verändern sich nicht in ihr, aber sie gewöhnen sich an ihre Wohnung, und wenn sie von da in seine Hände steigen, so ist es, als wären sie natürliche Gebärden dieser Hände."187 (RILKE, 1996, p. 436-437). Seu olhar havia sido exercitado tão intensamente que nada lhe escapava e a impressão visual captada durante sessão com o modelo era preservada na

\footnotetext{
184 “Ele não permitia que sua imaginação se expandisse; ele não inventava nada." (RILKE, 2003, p. 54).

185 "Ele não dá razão à primeira impressão, nem à segunda, e a nenhuma das subsequentes. Ele observa e anota." (RILKE, 2003, p. 57).

186 "Ele não pede informações à pessoa que deseja representar, pois não quer saber nada além daquilo que seus olhos vêem. E eles vêem tudo.” (RILKE, 2003, p. 58).

187 "Sua lembrança é ampla e espaçosa, as impressões não se modificam nela; entretanto, habituam-se à sua morada, e quando de lá sobem às suas mãos, é como se fossem gestos naturais destas mãos.” (RILKE, 2003, p. 58).
} 
memória. Rilke evidencia, dessa maneira, a centralidade do olhar no processo de criação de Rodin.

O trabalho do olhar é dotado de uma negatividade, pois ele implica na recusa de intenções e gestos pré-estabelecidos. Rilke reforça, nas descrições do modo de trabalho de Rodin, que o escultor pedia a seus modelos que se movimentassem espontaneamente e procurava observá-los nessa ação com o olhar mais neutro possível, evitando que conceitos ou informações previamente dados interferissem de alguma maneira em sua impressão visual. Manfred Koch identifica nesses procedimentos dois aspectos que ele chama de "negativos": "absichtslos" e "namenlos"188: "Kein Gedanke an etwas, was 'dargestellt', was damit 'gemeint' sein soll, darf in die Produktion einfließen. Auf Absichtslosigkeit sind bereits die Modelle zu trainieren." ${ }^{189}$ (KOCH, 2017, p. 212). Esses critérios negativos fazem parte do aprendizado do olhar e podem ser tomados como duas premissas importantes do trabalho de Rodin e da definição de um novo paradigma estético para Rilke. Rodin não tinha como objetivo criar novas representações de alegorias; seu interesse estava no gestual próprio da pessoa que posava para ele, na superfície do corpo do homem moderno. Sua intenção não era orientar o modelo a fazer uma pose que se adequasse a uma ideia prévia, era apreender o que estivesse surgindo espontaneamente diante de seus olhos. Reside nessa recusa em estabelecer previamente uma pose a falta de intenção (“Absichtslosigkeit") de sua escultura. Para capturar com o olhar os movimentos dos modelos, o artista precisa manter-se anônimo, abandonar suas opiniões, concepções, julgamentos: "Das Auge des Zeichners muss zum reinen, intentionslosen Medium für die Hand werden, die impulsiv die Bewegungen des Modells nicht zusammengefasst aufs Papier überträgt, sondern - selbst zitternd, schwankend und gelöst - mitvollzieht."190, e também a modelagem devia ser irrefletida, anônima, sem nome (KOCH, 2017, p. 213). Büssgen identifica nesse anonimato (“Namenlosigkeit") - ou seja, a suspensão de uma apreciação própria do artista - a "Sachlichkeit", a objetividade de Rodin, que existia porque ele era capaz de esquecer de si mesmo ("Selbstvergessenheit") enquanto trabalhava (cf. BÜSSGEN, 2013, p. 140).

\footnotetext{
188 “não intencional” e “anônimo” (tradução nossa).

189 'Nenhum conceito do que pode ser 'representado' ou 'pretendido' deve fluir para a produção. Os modelos devem ser mesmo treinados para a falta de intencionalidade.” (Tradução nossa).

190 “O olho do desenhista deve tornar-se um meio puro e não intencional para a mão, que não transfere impulsivamente para o papel os movimentos do modelo condensados, mas - ela mesma tremendo, vacilando, solta - concorre com eles.” (Tradução nossa).
} 
No entanto, ainda que Rilke tenha descrito Rodin como um artista que conseguia chegar a esse nível de objetividade, e que o próprio escultor tenha reafirmado que trabalhava em função da natureza, não de sua própria vontade, seu olhar não era neutro ou totalmente desprovido de objetivo: são suas percepções individuais, subjetivas, da natureza que estão fixadas em suas esculturas. O próprio Rodin reconhece esse fato quando, depois de admitir que fazia alterações nas formas, como acentuar uma saliência ou exagerar alguma medida, justificou esses procedimentos afirmando que os fazia guiado pelo seu sentimento, que o mostraria a natureza verdadeira: "Admito que o artista não percebe a natureza como ela aparece para os homens comuns, pois as emoções que ele sente lhe revelam as verdades interiores que jazem sob as aparências." (RODIN, 1990, p. 22-23). Herbert Read afirma que as obras do escultor francês retratam os sentimentos visuais do artista, e com isso os resultados alcançados chegariam a ser mais verazes do que os de uma fotografia. "If Rodin's statues were so realistic [...], this was not because he had any ideal of photographic accuracy, but because the representation he made corresponded exactly to the sensations he experienced.""191 (READ, 1996, p. 17-18). Rodin resume: "É só uma questão de ver." (RODIN, 1990, p. 23, grifo do autor), mas em seguida completa dizendo que o "[...] homem medíocre [...] olha sem ver." (RODIN, 1990, p. 23, grifo do autor); ou seja, é uma questão de saber ver, e esse conhecimento significa também estar em contato com os próprios sentimentos, pois estes atravessam tudo o que é visto e determinam a qualidade da obra. Segundo Rodin, o olho do artista está “[...] enxertado em seu coração, lê em profundidade no seio da Natureza." (RODIN, 1990, p. 23).

Quando interpelado por Paul Gsell sobre a beleza e a feiura na arte, Rodin responde que, embora o senso comum possa acreditar que o que é feio não possa ser adequado à arte, "O que, comumente, se chama feio na Natureza pode tornar-se de uma grande beleza na arte." (RODIN, 1990, p. 32, grifo do autor). De acordo com o escultor, os temas entendidos como "feios" - que seriam todos aqueles que estão em oposição ao que é sinal de saúde, regularidade e força, logo: a doença, a deformidade, a fraqueza, o sofrimento -, quando interpretados por mentes "claras e penetrantes" de grandes artistas ou grandes escritores, adquirem beleza. Rodin afirma ainda que "[...] em Arte, só é belo o que tem caráter." (RODIN, 1990, p. 34, grifo do autor), e explica que por caráter se refere àquilo que é

\footnotetext{
191 "Se as estátuas de Rodin eram tão realistas [...], isso não se deu porque ele possuía algum ideal de exatidão fotográfica, mas porque a representação que ele fez correspondia exatamente às sensações que ele experienciou." (Tradução nossa).
} 
intrínseco a qualquer manifestação da natureza: “[...] é uma verdade interior traduzida pela verdade exterior. O caráter é a alma, o sentimento e a ideia expressos pelos traços de um rosto, pelos gestos e ações de um ser humano, pelas cores de um céu, pela linha de um horizonte.” (RODIN, 1990, p. 34, grifos do autor). A feiúra na arte estaria relacionada apenas àquilo que é falso, artificial, inexpressivo, pretensioso, que mente para seu espectador. Como exemplo de um escritor que tornou belo um tema feio, Rodin cita o poema "Une charogne" ("Uma carniça"), de Charles Baudelaire, pelo fato de nele a beleza da uma mulher amada ser confrontada com o fato inescapável da decomposição do corpo (cf. RODIN, 1990, p. 32-34). Com esse argumento, Rodin reforça sua posição de que a arte deve buscar a verdade na natureza, e que esta é soberana em relação à atitude do artista; mas é por intermédio do olhar, atravessado pelo sentimento do artista, que a verdade da natureza pode ser transposta para a obra.

O próprio Baudelaire cria, em seu ensaio Le peintre de la vie moderne, de 1863, uma “[...] teoria racional e histórica do belo, em oposição à teoria do belo único e absoluto [...].”. O poeta defende que o belo é sempre necessariamente composto por duas partes: "O belo é feito de um elemento eterno, invariável, cuja quantidade é muito difícil de ser determinada, e de um elemento relativo, circunstancial, que será - como preferirem: um a cada vez ou todos ao mesmo tempo - a época, a moda, a moral, a paixão.” (BAUDELAIRE, 2010, p. 17). Ainda nesse ensaio, Baudelaire afirma que a intenção do artista flâneur, "[...] esse solitário dotado de uma imaginação ativa [...].”, é extrair de seu contexto moderno o que ele “[...] pode conter de poético, de extrair o eterno do transitório.” (BAUDELAIRE, 2010, p. 35). O elemento efêmero ou contingente (como é o caso da moda) só pode ser representado como belo se a ele for agregado outro, que lhe dê um caráter atemporal. Mesmo o poema "Une charogne" sendo anterior a esse ensaio (ele é parte do volume Les fleurs du mal, publicado pela primeira vez em 1857), nele Baudelaire faz, de certa maneira, essa junção entre eterno e efêmero: a ideia da juventude e a beleza feminina, historicamente ressaltados na arte como um tema belo, tem seu caráter efêmero evidenciado pelo eu lírico do poema, que aponta, em contrapartida, a inevitabilidade da morte e da decomposição, lei imutável da natureza. A teoria baudelairiana sobre o belo na arte encontra reverberação na passagem em que Rilke fala sobre os retratos executados por Rodin:

Ein Bildnis schaffen hieß für ihn, in einem gegebenen Gesichte Ewigkeit suchen, jenes Stück Ewigkeit, mit dem es teilnahm an dem großen Gange ewiger Dinge. Er hat keinen gebildet, den er nicht ein wenig aus den Angeln gehoben hätte in die Zukunft hinein; wie man ein Ding vor den Himmel hält, um seine Formen reiner und einfacher zu verstehen. Das ist nicht, was man verschönern heißt, und auch charakteristisch machen ist kein passender Ausdruck dafür. Es ist mehr; es ist: das 
Dauernde vom Vergänglichen scheiden, Gericht halten, gerecht sein. ${ }^{192}$ (RILKE, 1996, p. 434).

Nesse trecho, Rilke reconhece que Rodin faz modificações na aparência dos retratados, mas afirma que ele as teria feito apenas para ressaltar as qualidades "eternas" que encontrava em suas fisionomias, e as efígies de Victor Hugo e Balzac seriam exemplares nesse sentido.

A referência ao poema de Baudelaire não é gratuita: o poeta francês é como um predecessor literário de Rodin. A decisão de Baudelaire trazer para a poesia as expressões coloquiais dos transeuntes de Paris é análoga à que Rodin faz ao esculpir os gestos nervosos do homem moderno. Rilke afirma na monografia que Rodin sempre se manteve em estreita ligação com a literatura. Com efeito, Rilke menciona diversos artistas ao longo do texto, contemporâneos ou anteriores, que ele mesmo relaciona de alguma forma à obra de Rodin esses artistas nunca são mencionados como pessoas que se relacionaram diretamente com Rodin, ou que tiveram algum papel em sua formação ou no desenvolvimento de seus métodos. Os únicos nomes que são explicitamente trazidos como tendo um real impacto no trabalho do escultor são dois escritores, Dante e Baudelaire. Ambos souberam descrever os corpos dos homens de suas épocas, e suas descrições são tão imagéticas quanto a pintura ou a escultura:

Er las zum ersten Male Dantes Divina Comedia. Es war eine Offenbarung. Er sah die leidenden Leiber eines anderen Geschlechtes vor sich, sah, über alle Tage fort, ein Jahrhundert, dem die Kleider abgerissen waren, sah das große und unvergeßliche Gericht eines Dichters über seine Zeit. [...] Und von Dante kam er zu Baudelaire. Hier war kein Gericht, kein Dichter, der an der Hand eines Schattens zu den Himmeln stieg [...]. [...] er fühlte in Baudelaire einen, der ihm vorangegangen war, einen, der sich nicht von den Gesichtern hatte beirren lassen und der nach den Leibern suchte, in denen das Leben größer war, grausamer und ruheloser. ${ }^{193}$ (RILKE, 1996, p. 413).

192 "Criar um retrato significava para ele buscar eternidade em determinado rosto, aquele pedaço de eternidade com o qual este rosto participava da grande sucessão das coisas eternas. Ele não modelou nenhum que não tivesse modificado um pouco, conduzindo-o para dentro do futuro, assim como colocamos um objeto em direção à claridade do céu para compreendermos suas formas de maneira mais pura e simples. Não se trata aqui do que se chama embelezar, e tampouco o termo caracterizar é adequado. É mais; significa separar o perene do efêmero, julgar, ser justo.” (RILKE, 2003, p. 55-56).

193 "Pela primeira vez ele leu a Divina comédia, de Dante. Foi uma revelação. Ele viu os corpos sofridos de um outro gênero humano, viu, por dias incontáveis, um século do qual foram arrancadas as roupas, viu o grande e inesquecível julgamento de um poeta que proferiu a sua sentença condenatória contra a sua época. [...] E de Dante ele voltou-se para Baudelaire. Aqui não havia um julgamento, um poeta que, pelas mãos de uma sombra, subia aos céus. [...] Ele sentia que Baudelaire havia sido seu precursor, tendo sido ele alguém que não se deixara desnortear pelos rostos, buscando, em contrapartida, os corpos nos quais a vida era mais intensa, cruel e conturbada. (RILKE, 2003, p. 26-27). 
A poesia de Baudelaire é fundada em cenas, lugares e personagens da metrópole moderna, e ela cria imagens pungentes de corpos, gestos e olhares registrados pelo poeta na cidade.

Segundo Koch, os gestos textuais ("textuellen Gebärden") do homem moderno na poesia baudelairiana ganharam forma espacial e plástica pelas das mãos de Rodin, que se baseou nos poemas de Les fleurs du mal em sua criação escultórica (cf. KOCH, 2013, p. 493494). Essa associação entre Rodin e Baudelaire acrescentou novas possibilidades para a reflexão de Rilke sobre as diferenças entre os meios artísticos e as suas correspondências uma reflexão que, de acordo com o crítico, culmina com as cartas sobre Cézanne de 1907 (cf. KOCH, 2013, p. 493). Koch cita ainda o trecho de uma carta que Rilke escreveu a Lou Andreas-Salomé, em 10 de outubro de 1903, como uma continuidade dessa reflexão associada ao próprio trabalho: "Irgendwie muß auch ich dazu kommen, Dinge zu machen; nicht plastische, geschriebene Dinge, - Wirklichkeiten, die aus dem Handwerk hervorgehen."194 (ANDREAS-SALOMÉ; RILKE, 1989, p. 105). A escrita poética ganha aspectos de trabalho manual, de um labor - uma escrita laboriosa e manual - que resultaria não em poemas, mas em coisas escritas. Rilke evoca aqui as qualidades materiais da escrita e da palavra, e a possibilidade de criar a ilusão de realidade a partir do trabalho, como Rodin cria, através do trabalho, a ilusão de carne e movimento do corpo humano na escultura.

Rilke também foi leitor de Baudelaire, como atestam suas cartas daquele período (cf. ANDREAS-SALOMÉ; RILKE, 1989, p. 65), e encontrou nele, além de um poeta, um modelo de crítico de arte; segundo Koch, o entendimento que o poeta francês tinha do artista como "herói da vida moderna" advém de uma frase de Emerson ${ }^{195}$, e Rilke teria adotado ambas as ideias para desenvolver a representação de Rodin em sua monografia (cf. KOCH, 2017, p. 216). É interessante notar que a maneira como Rilke retrata Rodin na monografia se assemelha em diversos aspectos ao retrato que Baudelaire faz de Constantin Guys em Le peintre de la vie moderne. Baudelaire começa seu ensaio com reflexões sobre a moda e a representação dos costumes, para depois introduzir seu assunto principal, que é a obra de Guys. Ele começa dizendo que o trabalho que irá apresentar foi feito por “[...] um homem singular, de uma originalidade tão forte e decidida que se basta a si mesma, e nem sequer busca aprovação.”, que “[...] leva a originalidade ao extremo da modéstia.” (BAUDELAIRE,

\footnotetext{
194 "De alguma forma, devo chegar também a fazer coisas; não plásticas, coisas escritas, - realidades, que resultem do trabalho manual." (Tradução nossa).

195 "The hero is he who is immovably centered." (EMERSON apud KOCH, 2017, p. 216). ["O herói é aquele que é inamovivelmente centrado." (Tradução nossa).]
} 
2010, p. 21). Tamanha seria a modéstia do artista, que ele desejaria permanecer anônimo, e por esse motivo Baudelaire estabelece um pacto com o leitor:

Fingiremos acreditar, o leitor e eu, que o Sr. G. não existe, e nos ocuparemos de seus desenhos e de suas aquarelas [...]. [...] suporemos que tudo o que tenho a dizer a respeito de sua natureza tão curiosa e misteriosamente brilhante é, de forma mais ou menos justa, sugerido pelas obras em questão; pura hipótese poética, conjetura, trabalho e imaginação. (BAUDELAIRE, 2010, p. 21-22).

Mais pontos de contato com a monografia de Rilke sobre Rodin continuam a surgir: Guys é descrito como "[...] um homem de idade." que, no início, “[...] desenhava como um bárbaro [...]." e, ao longo do tempo, “[...] descobriu, inteiramente só, todos os pequenos truques do ofício e que construiu, sem conselhos, sua própria educação, tornou-se, à sua maneira, um influente mestre [...]." (BAUDELAIRE, 2010, p. 22). Baudelaire diz em seguida que reconheceu em Guys um "[...] homem do mundo [...].”, ou seja, "[...] homem do mundo inteiro, homem que compreende o mundo e as razões misteriosas e legítimas de todos os seus usos [...].”, e não um artista, que seria o “[...] especialista, homem preso à sua palheta como o servo à sua gleba." (BAUDELAIRE, 2010, p. 22-24, grifo do autor). Grande parte das qualidades de Guys ressaltadas ou conferidas por Baudelaire no texto é semelhante às que, anos depois, Rilke atribui a Rodin: a humildade, a obstinação e o autodidatismo ("sem conselhos") até tornar-se influente, a liberdade com que usa seus materiais de trabalho, grande sensibilidade e capacidade de observação.

Mas Guys é o artista flâneur por execelência, o "[...] observador apaixonado [...].", para quem "[...] constitui um grande prazer fixar domicílio no número, no inconstante, no movimento, no fugidio e no infinito.", e "Sua paixão e sua profíssão consistem em esposar a multidão." (BAUDELAIRE, 2010, p. 30, grifo do autor). Rodin, por outro lado, pela própria natureza de seu ofício, precisa trabalhar com constância dentro de seu estúdio. Rilke também se esforça em retratá-lo como um artista inteiramente concentrado no trabalho, não desprovido de paixão, certamente, mas que não se deixa levar por ela: na descrição de Rilke, Rodin está sempre no controle de suas ações. Ainda assim, em seu processo de trabalho, está menos distante do flâneur baudelairiano do que se poderia pensar à primeira vista:

Pode-se também compará-lo, esse indivíduo, a um espelho tão grande quanto essa multidão; a um caleidoscópio dotado de consciência que, a cada um de seus movimentos, representa a vida múltipla e a graça cambiante de todos os elementos da vida. É um eu insaciável do não-eu, que, a cada instante, o traduz e o exprime em imagens mais vivas que a própria vida, sempre instável e fugidia. (BAUDELAIRE, 2010, p. 30-31, grifos do autor). 
Segundo o texto de Rilke, Rodin treinou seu olhar ao ponto de ser capaz de esquecer-se de si mesmo para ver e capturar os movimentos de seus modelos de forma que seu olhar fosse contaminado o mínimo possível por seus próprios desejos e inferências. Tudo o que seus olhos viam e sua memória registrava se tornava material para criar suas esculturas que pareciam vivas:

Sein Auge sieht während der Sitzungs-Stunden viel mehr, als er in dieser Zeit ausführen kann. Er vergiß nichts davon und oft, wenn das Modell ihn verlassen hat, beginnt für ihn das eigentliche Arbeiten aus der Fülle seiner Erinnerung. Seine Erinnerung ist weit und geräumig; die Eindrücke verändern sich nicht in ihr, aber sie gewöhnen sich an ihre Wohnung, und wenn sie von da in seine Hände steigen, so ist es, als wären sie natürliche Gebärden dieser Hände. ${ }^{196}$ (RILKE, 1996, p. 436-437).

Essa imagem do artista absorto em trabalhar a partir da memória do que foi visto anteriormente ecoa a descrição que Baudelaire faz de Guys, quando este, depois de passar o dia mergulhado na multidão, volta para casa à noite para registrar no papel os elementos captados por seus olhos:

Poucos são os homens dotados da faculdade da visão; são menos ainda os que possuem a capacidade de expressão. Agora, no momento em que os outros dormem, esse homem está curvado sobre a mesa, lançando sobre uma folha de papel o mesmo olhar que há pouco fixava sobre as coisas, [...] apressado, violento, ativo, como se temesse que as imagens lhe escapassem, brigando sozinho, esbarrando em si mesmo. $\mathrm{E}$ as coisas renascem sobre o papel, naturais, e mais que naturais; belas, e mais que belas; singulares e dotadas, como a alma do autor, de uma vida em estado de exaltação. (BAUDELAIRE, 2010, p. 32).

O escultor, na descrição do poeta, não tem o nervosismo e a exaltação do Guys de Baudelaire: o Rodin retratado por Rilke é senhor de si mesmo, tem o domínio de suas capacidades. Muito embora Rilke não utilize o termo gênio para se referir a Rodin, o modo como retrata o escultor na monografia tem, por vezes, aspectos que o associam ao ideial do gênio criativo e original ${ }^{197}$. Entre as definições da palavra génie no Dictionnaire de l'Académie françoise, de 1694, há uma que diz: “On dit 'Travailler de génie' pour dire, Faire

\footnotetext{
196 "Nas sessões os seus olhos vêem muito mais do que ele pode realizar naquele espaço de tempo. Ele não esquece nada daquilo que observa e frequentemente, após a saída do modelo, começa para ele o trabalho propriamente dito, em cuja elaboração recorre à riqueza de sua lembrança. Sua lembrança é ampla e espaçosa, as impressões não se modificam nela; entretanto, habituam-se à sua morada, e quando de lá sobem às suas mãos, é como se fossem gestos naturais destas mãos.” (RILKE 2003, p. 58).

${ }^{197}$ Rilke não alude diretamente ao tema do gênio, e uma tentativa de retraçar quaisquer concepções específicas de gênio que estejam subentendidas no texto da monografia demandaria uma extensa pesquisa. Uma vez que este não é o foco desta dissertação, tomaremos aqui como referência algumas definições de gênio original que surgiram na Europa no final do século XVII e ao longo do século XVIII e que têm maior reverberação até os dias de hoje, ou seja, o gênio como um poder intelectual intrínseco e elevado (cf. BRUNO, 2010, p. 12).
} 
quelque chose de sa prope invention."198 (apud JAFFE, 1980, p. 582). Kineret Jaffe explica que no início do século XVIII, invenção e imitação não eram entendidos como procedimentos opostos: "The artist who imitated nature directly was seen as 'original' [...]. For one who had a special genius for art, his 'inventive faculty' allowed him to see relationships in nature that had never been seen before and to imitate them in painting or writing."199 (JAFFE, 1980. p. 582). Dentre os autores que refletiram sobre o termo "gênio" no século XVIII, Paul Bruno destaca Joseph Addison, que defendia que o gênio podia tanto ser inato quanto adquirido através do estudo (cf. BRUNO, 2010, p. 20). Para Edward Young, as origens do gênio são "[...] at times divine, at times natural, but always beyond reason."200 (BRUNO, 2010, p. 24) e, ao associar o gênio ao divino, Young traz à tona a tensão que existe entre o estudo e a criatividade espontânea, sugerindo que a última poderia ter origem divina (cf. BRUNO, 2010, p. 25).

Na monografia sobre Rodin, Rilke não se refere ao escultor como gênio e, embora haja semelhanças com a noção de gênio descrita no parágrafo anterior, há também uma contradição: ao mesmo tempo em que é reforçada a ideia de distanciamento (e, mesmo, de neutralidade) do olhar do escultor em relação aos objetos que retratava - sintetizada na noção de Absichtslosigkeit -, Rilke não se preocupa em investigar ou aprofundar quais teriam sido os motivos que o levaram a trabalhar com essa objetividade. Nas primeiras páginas do texto, quando trata do início da trajetória de Rodin, Rilke afirma: "Er fühlte, wo man anfangen mußte; eine Ruhe, die in ihm war, zeigte ihm den weisen Weg. An dieser Stelle offenbart sich schon Rodins tiefe Übereinstimmung mit der Natur [...]."201 (RILKE, 1996, p. 409). Algumas páginas adiante, ele retoma uma ideia semelhante: "Immer und immer wieder kam Rodin bei seinen Akten auf dieses Sich-nach-innen-Biegen zurück, auf dieses angestrengte Horchen in die eigene Tiefe [...]." ${ }^{202}$ (RILKE, 1996, p. 420). Essa contradição talvez possa ser resolvida trazendo à discussão a concepção de gênio elaborada por Baudelaire também em Le peintre

\footnotetext{
198 “Diz-se ‘Trabalhar com gênio’ para dizer, Fazer qualquer coisa de sua própria invenção.” (Tradução nossa).

199 “'O artista que imitava a natureza diretamente era visto como 'original' [...]. Para aquele que possuía um gênio especial para a arte, sua 'faculdade inventiva' o permitia ver relações na natureza que nunca haviam sido vistas antes e imitá-las na pintura ou na escrita.” (Tradução nossa).

200 “[...] por vezes divina, por vezes natural, mas sempre além da razão.” (Tradução nossa).

201 "Ele sentia onde era necessário começar; uma paz, que nele residia, mostrou-lhe o caminho do bom senso. Já nesta fase revela-se a profunda harmonia existente entre Rodin e a natureza [...].” (RILKE, 2003, p. 21).

202 "Em sua arte plástica, ao realizar os seus nus, Rodin sempre retornou a este voltar-se-para-o-interior, a este auscultar intenso daquilo que se encontrava em seu próprio íntimo.” (RILKE, 2003, p. 36).
} 
de la vie moderne. No ensaio, o poeta francês afirma que a curiosidade que move Constantin Guys é a mesma de um convalescente, que após um período de recolhimento, anseia por recordar-se novamente da vida e, com esse anseio, atira-se à multidão:

\begin{abstract}
Ora, a convalescência é como um retorno à infância. O convalescente goza, no mais alto grau, tal como a criança, da faculdade de se interessar vivamente pelas coisas, até mesmo por aquelas mais aparentemente triviais. [...] A criança vê tudo como novidade; ela está sempre inebriada. Nada se assemelha mais àquilo que chamamos de inspiração do que a alegria com a qual uma criança absorve a forma e a cor. Eu ousaria ir mais longe; afirmo que a inspiração tem alguma relação com a congestão, e que todo pensamento sublime vem acompanhado de um espasmo nervoso, mais ou menos forte, que reverbera até no cerebelo. $\mathrm{O}$ homem de gênio tem os nervos sólidos; a criança tem-nos fracos. Num, a razão tomou um espaço considerável; na outra, a sensibilidade ocupa quase todo o ser. O gênio não é, entretanto, senão a infância controladamente recuperada, a infância agora dotada, para expressar-se, de órgãos viris e do espírito analítico que lhe permitem ordenar a soma involuntariamente acumulada de materiais. (BAUDELAIRE, 2010, p. 25-28, grifos do autor).
\end{abstract}

Baudelaire termina dizendo que Guys, seu exemplo de artista flâneur, é como um "[...] homem-criança, como um homem que possui, a cada minuto, o gênio da infância, isto é, um gênio para o qual nenhum aspecto da vida está embotado.” (BAUDELAIRE, 2010, p. 28, grifo do autor). Ora, nas primeiras páginas da monografia, Rilke, ao mesmo tempo em que afirma que não é possível saber nada sobre a infância de Rodin, pressupõe que ela deve ter permanecido viva no âmago do escultor:

Und es hat diese Kindheit vielleicht noch, denn -, sagt der heilige Augustinus einmal, wohin sollte sie gegangen sein? Es hat vielleicht alle seine vergangenen Stunden, die Stunden der Erwartung und der Verlassenheit, die Stunden des Zweifels und die langen Stunden der Not, es ist ein Leben, das nichts verloren und vergessen hat, ein Leben, das sich versammelte, da es verging. Vielleicht, wir wissen nichts davon. Aber nur aus einem solchen Leben, glauben wir, kann eines solchen Wirkens Fülle und Überfluß entstanden sein, nur ein solches Leben, in dem alles gleichzeitig ist und wach und nichts vergangen, kann jung und stark bleiben und sich immer wieder zu hohen Werken erheben. ${ }^{203}$ (RILKE, 1996, p. 405-406).

Rilke assume que apenas uma pessoa que não tivesse deixado para trás sua infância poderia chegar à grandiosidade de Rodin, porque é na infância que se tem o olhar investigativo, curioso e, antes de tudo, objetivo - pois se tudo ainda é novo, a mente infantil não teve tempo e oportunidade de consolidar ideias pré-concebidas que contaminem o olhar para as coisas. Essa concepção dialoga diretamente com a noção de gênio baudelairiana, e também retoma

203 "E esta vida possivelmente ainda tenha esta infância, pois, como disse certa vez Santo Agostinho - para onde ela teria ido? Esta vida compreende talvez todas as suas horas passadas, as horas da expectativa e da solidão, as horas da incerteza e as longas horas da angústia. É uma vida que nada perdeu e nada esqueceu, uma vida que se concentrou quando se exauria. É possível, entretanto nada sabemos a respeito. Mas acreditamos que somente do fulcro de uma vida como esta podiam nascer a riqueza e a exuberância de uma obra deste porte. Somente uma vida na qual tudo é simultâneo, lembrado e preservado, pode manter-se jovem e forte e sempre alçar-se novamente à altura das grandes obras." (RILKE, 2003, p. 16). 
ideias que Rilke expressou em seus textos estéticos anteriores, mencionados na segunda seção deste capítulo, nomeadamente o ensaio "Über Kunst" e a introdução à monografia Worpswede.

Estão em jogo, aqui, diferentes concepções de gênio. $O$ gênio adquirido pelo estudo (no caso do escultor, do trabalho constante e da observação da natureza), o gênio inato - este, talvez, de origem divina - e o gênio da infância. Os três parecem caminhar juntos e se complementarem em Rodin. Apesar dos anos de dedicação intensa e exclusiva ao trabalho, Rilke deixa claro que Rodin era um artista autossuficiente, que prescindiu da orientação de um mestre, e soube sozinho qual caminho deveria seguir, seja porque possuía em seu íntimo as indicações que precisava, ou por ter preservado uma disposição de curiosidade infantil que o levou às experimentações que vieram a se tornar o diferencial de sua escultura. Em todo caso, é importante ressaltar que a linguagem utilizada por Rilke na monografia tem tons de adoração religiosa (cf. KOCH, 2017, p. 211), e coloca Rodin na posição de mestre absoluto em seu ofício, de um criador praticamente divino. Hoffmann ressalta que a linguagem religiosa utilizada por Rilke na palestra sobre Rodin tem o intuito de tratar a poética do escultor como uma mensagem de ajuda, em especial às pessoas jovens: "Nicht Kunstvermittlung, sondern Lebenshilfe ist Rilkes mit dem Vortrag verfolgtes Ziel."204 (HOFFMANN, 2010, p. 560). O próprio Rilke admite, em cartas escritas em 1906, que o que o motiva a proferir sua fala sobre o artista, de cidade a cidade, é a crença de que o pensamento de Rodin sobre arte e criação artística carrega em si “[...]'der Weg, die Wahrheit und das Leben." "205 (RILKE apud HOFFMANN, 2010, p. 560). A analogia entre Rodin e uma figura divina coloca Rilke na posição de profeta, que tem como tarefa propagar a mensagem de seu mestre - através da monografia e da palestra sobre o fazer artístico rodinesco - uma posição reforçada inclusive por Clara Rilke-Westhoff em uma carta a Rodin (cf. HOFFMANN, 2010, p. 561).

De acordo com Rilke, Rodin teria avistado sozinho com clareza o caminho a percorrer, e o período de solidão teria sido importante porque, nesse ínterim, não havia nenhuma crítica, elogio ou sugestão que pudesse desviá-lo de seus objetivos; sua própria motivação era suficiente para guiá-lo. "Wie Parzifal heranwächst, so wuchs sein Werk in Reinheit heran,

\footnotetext{
204 "Não a comunicação da arte, mas o aconselhamento, é o objetivo pretendido por Rilke com sua palestra." (Tradução nossa).

205 “O caminho, a verdade e a vida.” (Tradução nossa).
} 
allein mit sich und mit einer großen ewigen Natur."206 (RILKE, 1996, p. 414): o processo de amadurecimento artístico do escultor é comparado ao percurso do cavaleiro que se aventurou a procurar uma relíquia sagrada. Quando seu trabalho já está maduro, Rodin possuiria capacidades quase divinas: quando executa um retrato, trabalha "[...] wie Gott den ersten Menschen gemacht hat, ohne die Absicht, etwas anderes zu wirken als das Leben selbst, namenloses Leben." ${ }^{207}$ (RILKE, 1996, p. 433). Seu ofício não era apenas modelar, tornar plástico e belo um corpo ou rosto humano, e sim, fazer-lhe justiça: "Es ist mehr; es ist: das Dauernde vom Vergänglichen scheiden, Gericht halten, gerecht sein.”208 (RILKE, 1996, p. 434). Rilke chega a afirmar que "Menschen redeten nicht zu ihm. Steine sprachen."209 (RILKE, 1996, p. 418), talvez procurando deixar assim implícito que a natureza é a única que ensina, que Rodin seria dotado de uma sensibilidade única e, em sua obstinação, chegado ao ponto de conseguir compreender todas as particularidades de seu material. Dessa forma, ele teria chegado a um domínio tão completo de suas técnicas que para ele havia deixado de existir a possibilidade do erro: "Er kann nicht mehr irren."210 (RILKE, 1996, p. 449); sua minúcia também não deixava nenhum elemento ao acaso: "Es giebt an diesem Kopf keine Linie, keine Überschneidung, keinen Kontur, den Rodin nicht gesehen und gewollt hat."211 (RILKE, 1996, p. 416). E, quando foi chegada a hora de trazer sua obra a público, Rodin havia adquirido total segurança em seu próprio trabalho, "Da, als man anfing an ihm zu zweifeln, hatte er keinen Zweifel mehr an sich selbst." ${ }^{212}$ (RILKE, 1996, p. 414). Essa excelência artística de aspecto divino teria sido atingida por Rodin, segundo o poeta, através do trabalho contante. Por esse ponto de vista, a dedicação total à criação levaria o artista a uma espécie de salvação, ou a um estado mais puro de existência, como a de um santo.

\footnotetext{
206 "Assim como Parsifal se desenvolveu, desenvolvia-se sua obra com pureza, estando ele sozinho consigo mesmo e com uma imensa, eterna natureza.” (RILKE, 2003, p. 28).

207 “[...] como Deus havia criado o primeiro ser humano, sem a intenção de produzir algo que não fosse a própria vida, a vida imensa, indizível.” (RILKE, 2003, p. 54).

208 “É mais; significa separar o perene do efêmero, julgar, ser justo.” (RILKE, 2003, p. 56).

209 “Seres humanos não falavam com ele. Falavam as pedras.” (RILKE, 2003, p. 34).

210 “Para ele, já não há mais o que errar.” (RILKE, 2003, p. 75).

211 "Inexiste nesta cabeça uma única linha, alguma interseção ou algum contorno que Rodin não tivesse visto e desejado.” (RILKE, 2003, p. 30).

212 “Quando começaram a duvidar dele, ele já não mais duvidava de si mesmo.” (RILKE, 2003, p. 28).
} 
Rilke reitera diversas vezes que Rodin se dedicava incondicionalmente ao trabalho, o que o teria levado a uma completude artística, ao total domínio de suas técnicas. Uma vez que a motivação do escultor era ser fiel à natureza e representá-la tal como ela é, sem fazer alterações, era de primeira importância que estivesse atento a ela a todo o momento. O trabalho de Rodin era incessante, pois tudo o que passasse por seus olhos poderia transformarse em matéria para suas obras; assim, toda sua atenção estava voltada à vida, aos movimentos dos corpos e em como reproduzi-los na escultura. Segundo Rilke, Rodin entendia esse trabalho como algo a ser feito com paciência e humildade, no ateliê, mentalmente, "[...] sie [die Arbeit] ist nicht das Weithinsichtbare. Sie geht in den Werkstätten vor sich, in den Stuben, in den Köpfen; im Dunkel. Er weiß es, denn auch seine Arbeit ist so; und er arbeitet unaufhörlich. Sein Leben geht wie ein einziger Arbeitstag."213 (RILKE, 1996, p. 448). Rilke chega mesmo a afirmas que o trabalho implica uma renúncia à própria vida para dedicar-se a observar e a compreender a natureza. O ideal do trabalho constante não está ligado apenas ao desejo de atingir a excelência artística. Ele diz respeito a uma necessidade imposta pela atividade artística em si: mesmo que o artista possua dentro de si um impulso inato que o leva a criar (como Rilke dá a entender que é o caso de Rodin), ele só poderá aperfeiçoar suas ideias ao longo do tempo, através de muita dedicação ao trabalho, ao estudo e à pesquisa. Em uma carta escrita em 11 de setembro de 1902, Rilke diz a Rodin que essa foi uma lição importante que recebeu dele:

\begin{abstract}
C'est ne pas seulement pour faire un étude, que je suis venu chez vous, - c'était pour vous demander: comment faut-il vivre? Et vous m'avez répondu: en travaillant. Et je le comprends bien. Je sens que travailler c'est vivre sans mourir. Je suis plein de reconaissance et de joie. Car depuis ma première jeunesse, je ne voulais que cela. Et je l'ai essayé. Mais mon travail, parce que je l'aimais tant, est devenu pendant ces années une chose solennelle, une fête, attachée à des inspirations rares; et il y avait des semaines où je ne faisais rien qu'attendre avec des tristesses infinies l'heure créatrice. C'était une vie pleine d'abîmes. [...] Mais en tout ce qui était raisonnable sans doute, je n'ai pas eu le courage de remporter les inspirations lointaines en travaillant. Maintenant je sais que c'est le seul moyen de les garder. - Et c'est la grande renaissance de ma vie et de mon espoir que vous m'avez donné. ${ }^{214}$ (RILKE, 1929, p. 41).
\end{abstract}

\footnotetext{
213 "Ele [o trabalho] não é algo que se vê de longe. Ele se realiza em oficinas, em salas, nas cabeças; na escuridão. Ele [Rodin] o sabe, pois o seu trabalho também é assim; e ele trabalha sem cessar. Sua vida transcorre como um único dia de trabalho." (RILKE, 2003, p. 74).

214 "Não foi apenas para fazer um estudo que vim encontrá-lo, - foi para perguntar-lhe: como se deve viver? E você me respondeu: trabalhando. E eu o entendo bem. Sinto que trabalhar é viver sem morrer. Estou pleno de reconhecimento e alegria. Pois desde minha primeira juventude, não queria outra coisa. E tentei fazê-lo. Mas meu trabalho, porque eu o amava tanto, tornou-se, no decorrer desses anos, algo solene, uma festa, atrelado às inspirações raras; e havia semanas em que eu não fazia nada além de esperar com infinita tristeza pela hora criativa. Era uma vida cheia de abismos. [...] Mas em tudo que era sem dúvida razoável, não tive coragem de conquistar as inspirações distantes pelo trabalho. Agora sei que essa é a única maneira de guardá-las. - E esse é o grande renascimento de minha vida e de meu espírito que você me deu." (Tradução nossa).
} 
Kopp explica que há uma mudança de paradigma a respeito do trabalho artístico na Modernidade: não é mais possível esperar por uma inspiração divina, as ideias não acometem o artista sem que haja esforço de sua parte:

\begin{abstract}
Inspiration ist kein Geschenk Gottes mehr, sondern nach einem Wort Baudelaires die Schwester der täglichen Arbeit. Arbeit und Einsamkeit stehen synonym für die Berufung des Künstlers, für dessen Recht, das Leben als Experiment für die Kunst zu führen und ihr letzlich alles unterzuordnen. ${ }^{215}$ (KOPP, 1999, p. 181).
\end{abstract}

Aqui ressurge a associação entre arte e religião feita por Rilke: não há inspiração divina, mas a dedicação do artista ao trabalho artístico ganha conotação religiosa: "Ich dachte, Paris würde mir vieles bringen: Leben, Wünsche, Zukunft und Zuversicht und eines vor allem, ein Heiliges: Arbeit." ${ }^{216}$ (RILKE apud KOPP, 1999, p. 181). Apesar de divinizar o trabalho e a figura do artista, a obra de arte não é entendida por Rilke como um objeto sacralizado: a arte parece assumir a função da religião no sentido de que ela pode transformar o artista (através do trabalho) e também o espectador, quando este entra em contato com uma obra que representa algo real e verdadeiro (cf. HOFFMANN, 2010, p. 561). É exemplar dessa ideia o último verso de "Archaischer Torso Apollos" - poema que abre Der Neuen Gedichte anderer Teil, de 1908, livro que Rilke dedica a Rodin - no qual a experiência de observar a obra de arte leva ao imperativo "Du muß dein Leben ändern."217 (RILKE, 1975, p. 83).

\title{
2.4. Briefe über Cézanne
}

No segundo semestre de 1907, Rilke escrevia de Paris a Clara Rilke-Westhoff, sua esposa, com frequência quase diária, detalhes de suas repetidas visitas ao Salon D'Automne daquele ano. O salão havia organizado uma retrospectiva do trabalho de Cézanne, falecido no ano anterior, com 56 de suas pinturas. Após essas visitas, Rilke acalentou a ideia de escrever uma monografia a respeito do pintor francês, projeto que não levou a cabo; por esse motivo, quis que suas cartas fossem publicadas (cf. BÜSSGEN, 2013, p. 142). Clara editou a

\footnotetext{
215 “Inspiração não é mais um presente de deus, e sim, a partir de uma citação de Baudelaire, a irmã do trabalho cotidiano. Trabalho e solidão aparecem como sinônimos para a vocação do artista, para o princípio de seguir a vida como um experimento para a arte e a ela tudo subordinar." (Tradução nossa).

216 "Pensei que Paris me traria muitas coisas: vida, desejos, futuro e confiança, e uma delas acima de todas as outras, uma sagrada: trabalho." (Tradução nossa).

${ }^{217}$ Em uma tradução livre, "Deves mudar tua vida." (Tradução nossa).
} 
correspondência e a seleção foi publicada em 1952, mais de vinte anos após a morte de Rilke. Segundo Büssgen, em 1906, Rilke teve um desentendimento com Rodin que marcou o início de seu afastamento do escultor. Esse evento também teria contribuído para que o poeta voltasse sua atenção para a obra de Cézanne (cf. BÜSSGEN, 2013, p. 143). Diferentemente da relação com Rodin, no pintor Rilke havia encontrado não um mestre, mas um igual: alguém em quem ele reconhecia o seu próprio esforço em transpor para sua linguagem artística a sensação visual da materialidade do mundo. Se, na visão de Rilke, Rodin já havia alcançado essa realização com sucesso na escultura, Cézanne passara as últimas décadas de sua vida tentando fazer o mesmo na pintura, e seus quadros revelam seus êxitos, mas também suas limitações.

Como Rodin, Cézanne personifica para Rilke os ideais do trabalho constante, do olhar objetivo e da representação material na obra de arte. Pode-se tomar como eixos das cartas a reflexão sobre o processo criativo do artista e a representação material, que no caso das pinturas de Cézanne, Rilke chama de Dingwerdung. Nas cartas, Rilke não tem a preocupação de contextualizar a obra de Cézanne em relação ao desenvolvimento da pintura ocidental, como faz com a escultura de Rodin na monografia. Diferentemente do texto sobre Rodin, as cartas possuem poucas descrições de pinturas, e mesmo os procedimentos técnicos do artista são descritos brevemente. Isso se dá, em grande medida, pelo fato de que Rilke não conheceu o pintor pessoalmente, nunca se correspondeu com ele; não pôde, portanto, vê-lo trabalhar e conversar com ele a respeito de seus métodos, como pôde fazer com Rodin. Além disso, as cartas possuem reflexões pessoais do poeta: Rilke faz relações entre o trabalho de Cézanne e o de Van Gogh e mesmo o de Rodin, e relaciona também seus aprendizados a seu próprio trabalho nos livros Das Buch der Bilder, Neue Gedichte e Die Aufzeichnungen des Malte Laurids Brigge ${ }^{218}$.

Se na monografia Rilke dedica várias páginas a considerações sobre a vida de Rodin, sobre como teria acontecido seu desenvolvimento artístico e quais os fundamentos de sua prática, nas cartas, ele introduz essas informações sobre Cézanne de maneira direta e sucinta:

... heute wollte ich Dir ein wenig von Cézanne erzählen. Was die Arbeit angeht, so behauptete er, er hätte bis zu seinem vierzigsten Jahre als Bohémien gelebt. Da erst, in der Bekanntschaft mit Pissaro, wäre ihm der Geschmack an der Arbeit aufgegangen. Aber dann auch so sehr, daß er die späteren dreißig Jahre seines

\footnotetext{
${ }^{218}$ É preciso ainda lembrar que as cartas foram editadas por Clara Rilke-Westhoff, que selecionou quais trechos deveriam fazer parte da compilação. A primeira edição de Briefe über Cézanne, publicada em 1952 em Wiesbaden pela Insel-Verlag, contém um prefácio de Clara. Nele, ela escreve brevemente sobre as cartas que Rilke lhe escreveu sobre a pintura de Cézanne: "Ich schicke diesen Briefe einigen einleitende Briefe voraus." (RILKE, 1952, p. 5) [“Eu envio primeiramente uma carta introdutória a estas cartas.” (Tradução nossa)].
} 
Lebens nur noch gearbeitet hat. Ohne Freude eigentlich, wie es scheint, in fortwährender Wut, im Zwiespalt mit jeder einzelnen seiner Arbeiten, deren keine ihm das zu erreichen schien, was er für das Unentbehrlichste hielt. La réalisation nannte er es, und er fand es bei den Venezianern, die er früher im Louvre gesehen und wieder gesehen und unbedingt anerkannt hatte. Das Überzeugende, die Dingwerdung, die durch sein eigenes Erlebnis an dem Gegenstand bis ins Unzerstörbare hinein gesteigerte Wirklichkeit, das war es, was ihm die Absicht seiner innersten Arbeit schien [...]. ${ }^{219}$ (RILKE, 1996, p. 608).

Em menos de um parágrafo, Rilke resume a trajetória do pintor estritamente ao que o interessa: Cézanne dedicou décadas de sua vida inteiramente ao trabalho, e seu propósito artístico era o que chamava de la réalisation. Rilke apresenta nesse mesmo trecho uma definição do que seria o conceito de réalisation do pintor: é a Dingwerdung, ou "tornar-secoisa" ${ }^{220}$, "[...] die durch sein eigenes Erlebnis an dem Gegenstand bis ins Unzerstörbare hinein gesteigert Wirklichkeit [...]." ${ }^{221}$ - é a consumação, na pintura, da materialidade do objeto a partir da experiência visual que o artista tem dele. Não se trata de criar uma ilusão, um trompe-l'oeil, e sim da busca por uma representação conclusiva, convincente ("Das Überzeugende") e indestrutível ("Unzerstörbar") dessa materialidade, como se a pintura pudesse, diante dos olhos do espectador, transformar-se na coisa em si.

A Dingwerdung está relacionada à profundidade, que Cézanne trabalha em sua pintura com a cor, com sobreposições e justaposições de camadas em uma gama variada de matizes de cor. Merleau-Ponty critica a noção cartesiana de que a profundidade seja uma terceira dimensão, derivada da altura e da largura, e a ideia de que a pintura deve oferecer uma visão dos objetos como os veríamos na realidade se estivessem dispostos em diferentes planos. Esse artifício “[...] nos faz ver espaço onde não há espaço.” (MERLEAU-PONTY, 2015, p. 32), uma concepção problemática, segundo o filósofo, pelo fato de, na realidade, a profundidade não ser visível no sentido estrito; seria mais preciso dizer que percebemos a profundidade na nossa relação com as coisas e o mundo:

\footnotetext{
219 “... hoje gostaria de lhe contar um pouco sobre Cézanne. No que diz respeito ao trabalho, conforme ele mesmo afirmava, teria vivido até os seus quarenta anos como um boêmio. Só então, conhecendo Pissaro, nasceria nele o gosto pelo trabalho. Mas com tanta intensidade, que nos trinta anos seguintes de sua vida só fez trabalhar. Praticamente sem alegria, ao que parece, e constantemente enfurecido, em dilema com cada um de seus trabalhos, dos quais nenhum lhe parecia alcançar aquilo que ele considerava o mais indispensável. $L a$ réalisation, dizia ele, e a encontrava nos Venezianos que tinha visto e revisto no Louvre, dedicando a eles um reconhecimento incondicional. O convincente, o tornar-se-coisa, a realidade intensificada pela sua vivência do objeto, até tornar-se indestrutível, isto era o que lhe parecia ser a meta de seu trabalho mais íntimo." (RILKE, 2006, p. 50).

${ }^{220}$ A tradução utilizada para o termo “Dingwerden” é de Pedro Süssekind (cf. RILKE, 2006, p. 50).

221 “[...] a realidade intensificada pela sua vivência do objeto, até tornar-se indestrutível [...].” (RILKE, 2006, p. $50)$.
} 
[...] vejo objetos que se ocultam um no outro, e que portanto não vejo, já que estão um atrás do outro. Vejo a profundidade e ela não é visível, já que se mede de nosso corpo às coisas, e estamos colados a ele... [...] O que chamo profundidade é nada ou é minha participação num ser sem restrição, e primeiramente no ser do espaço para além do ponto de vista. As coisas se imbricam umas nas outras porque elas estão fora uma da outra. (MERLEAU-PONTY, 2015, p. 32-33, grifo do autor).

Merleau-Ponty lembra que não percebemos as coisas diante de nós, mas ao nosso redor (cf. MERLEAU-PONTY, 2015, p. 39) e, se compreendermos a profundidade como a existência simultânea das coisas, ela é também "[...] a experiência da reversibilidade das dimensões, de uma 'localidade' global onde tudo é ao mesmo tempo, cuja altura, largura e distância são abstratas, de uma voluminosidade que exprimimos numa palavra ao dizer que uma coisa está aí." (MERLEAU-PONTY, 2015, p. 42-43).

A profundidade que Cézanne buscava realizar na pintura era, segundo o filósofo, essa percepção de simultaneidade espacial. Em suas inúmeras tentativas, chegou à constatação de que era preciso "[...] buscar juntos o espaço e o conteúdo.”, e isso demandava trabalhar com a linha, a forma, e a cor (cf. MERLEAU-PONTY, 2015, p. 43). O papel da cor não era mais o de apenas imitar as cores na natureza; ela passava a ser aplicada em inúmeras camadas de diversos tons: na paleta de Cézanne

[...] há não apenas as sete cores do prisma, mas dezoito cores, seis vermelhos, cinco amarelos, três azuis, três verdes, um preto. $\mathrm{O}$ uso das cores quentes e do preto mostra que Cézanne quer representar o objeto, reencontrá-lo por trás da atmosfera. Do mesmo modo, ele renuncia à divisão do tom e a substitui por misturas graduadas, por uma sucessão de matizes cromáticos sobre o objeto, por uma modulação de cores que acompanha a forma e a luz recebida. (MERLEAU-PONTY, 2015, p. 129).

A escolha da gama mais variada de cores é um dos procedimentos que distinguem o trabalho de Cézanne da proposta dos Impressionistas. Enquanto estes estavam interessados em representar o objeto como fenômeno luminoso, Cézanne buscava a matéria, a sensação visual (que chamava de "petite sensation"222) da materialidade das coisas. Cézanne também abandonou o uso de um contorno único para as formas, marcando-as com múltiplos traços e pintando inúmeras camadas, procurando fazer com que a "espessura do mundo" resultasse do arranjo de cores (cf. MERLEAU-PONTY, 2015, p. 133-134): Em suas pinturas, "O objeto não está mais coberto de reflexos, perdido em suas relações com o ar e os outros objetos, ele é como que iluminado secretamente do interior, a luz emana dele, e disso resulta uma impressão de solidez e materialidade." (MERLEAU-PONTY, 2015, p. 129-130).

222 “pequena sensação” (Tradução nossa). 
Rilke menciona que nas pinturas de frutas, "Bei Cézanne hört ihre Eßbarkeit überhaupt auf, so sehr dinghaft wirklich werden sie, so einfach unvertilgbar in ihrer eigensinnigen Vorhandenheit."223 (RILKE, 1996, p. 608). Não importa qual tema for escolhido, o tratamento dado pelo pintor é o mesmo. Büssgen aponta que um dos aspectos centrais do contato de Rilke com o trabalho de Cézanne é a percepção da utilização da cor para transformar um objeto observado em "[...] ein autonomes 'Kunst-Ding' [...]."224 (BÜSSGEN, 2013, p. 143). Rilke descreve, em uma das cartas, um procedimento desenvolvido por Cézanne que ele pôde divisar na pintura:

Bei der dunkelsten Farbigkeit einsetzend, deckte er ihre Tiefe mit einer Farbenlage, die er ein wenig über sie hinausführte und immer so weiter, Farbe über Farbe hinaus erweiternd, kam er allmählich an ein anderes kontrastierendes Bildelement, bei dem er, von einem neuen Zentrum aus, dann ähnlich verfuhr. Ich denke mir, daß die beiden Vorgänge, des schauenden und sicheren Übernehmens und des SichAneignens und persönlichen Gebrauchens des Übernommenen, sich bei ihm, vielleicht infolge einer Bewußtwerdung, gegeneinander stemmten, daß sie sozusagen zugleich zu sprechen anfingen, einander fortwährend ins Wort fielen, sich beständig entzweiten. ${ }^{225}$ (RILKE, 1996, p. 609).

Em Cézanne, a pintura deixa de ser tida como artifício, como criação artificial de uma terceira dimensão, e o propósito do artista deixa de ser representar os objetos como parte de um mundo que está em frente a ele, separado dele. As coisas do mundo são autônomas, elas não existem por causa do referencial a partir do qual são representadas (no caso, a visão do artista); a busca de Cézanne é pela representação da existência material das coisas independentemente do referencial do artista. Ele próprio também é imerso nesse mundo, e o representa de dentro para fora, "[...] para mostrar como as coisas se fazem coisas e o mundo, mundo. [...] É essa animação interna, essa irradiação do visível que o pintor procura sob os nomes de profundidade, de espaço, de cor.” (MERLEAU-PONTY, 2015, p. 45).

O conceito de Dingwerdung traz para a pintura de Cézanne a mesma exigência do olhar objetivo que Rilke havia aprendido com Rodin - “[...] das Ideal eines 'einfachen

\footnotetext{
223 "Em Cézanne acaba por completo seu caráter comestível, tornam-se realmente coisas, irredutíveis em sua presença obstinada." (RILKE, 2006, p. 49).

224 “[...] uma coisa-arte autônoma [...].” (Tradução nossa).

225 "Começava pelo colorido mais escuro, cobria sua profundidade com uma capa de cor que conduzia até um pouco além daquele, e sempre mais longe, expandindo cor sobre cor, chegava a um outro elemento contrastante do quadro, com o qual, desde um novo centro, procedia de modo análogo. Parece-me que nele os dois procedimentos - o da captura observadora e firme, e o da apropriação, o uso pessoal do capturado - apóiam-se um contra o outro, talvez segundo uma tomada de consciência, de tal modo que os dois, por assim dizer, começam a falar ao mesmo tempo, em interrupções contínuas e discórdias constantes.” (RILKE, 2006, p. 51).
} 
Schauens' [...]."226 (BÜSSGEN, 2013, p. 144) -, ou da Sachlichkeit. No entanto, é preciso ressaltar que, nas cartas, a ideia da Sachlichkeit é desdobrada por Rilke primeiro a partir da mudança que ele percebe em seu próprio olhar, e só depois ele o relaciona diretamente à pintura de Cézanne. Na carta de 13 de outubro, o poeta diz à esposa: "Wenn ich hinaufkäme zu Euch, so würde ich gewiß auch den Prunk von Moor und Heide, das schwebend helle Grün der Wiesenstücke und die Birken neu und anders sehen [...]."227 (RILKE, 1996, p. 615, grifo nosso). Essa percepção de que sua maneira de ver o mundo havia mudado desencadeia uma reflexão sobre seu próprio trabalho:

[...] zwar hat diese Verwandlung, da ich sie einmal ganz erlebte und teilte, einen Teil des Stundenbuchs hervorgerufen; aber damals war mir die Natur noch ein allgemeiner Anlaß, eine Evokation, ein Instrument, in dessen Saiten sich meine Hände wiederfanden; ich $\mathrm{sa} \beta$ noch nicht vor ihr; ich ließ mich hinreißen von der Seele, welche von ihr ausging; sie kam über mich mit ihrer Weite, mit ihrem großen übertriebenen Dasein, wie das Prophezeihen über Saul kam; genau so. Ich schritt einher und sah, sah nicht die Natur, sondern die Gesichte, die sie mir eingab. Wie wenig hätte ich damals vor Cézanne, vor Van Gogh zu lernen gewußt. ${ }^{228}$ (RILKE, 1996, p. 615-616).

Rilke se refere aqui a seu volume de poemas Das Stundenbuch, composto entre 1899 e 1903, e revela que, quando o escreveu, ainda via a natureza não como a coisa em si, mas como um pretexto para evocar sentimentos - ou seja, Das Stundenbuch foi composto por ele ainda a partir da noção de Kunst-Vorwand desenvolvida na palestra "Moderne Lyrik" em 1898. Na carta, Rilke não menciona o aprendizado do olhar objetivo com Rodin, talvez porque ele tenha se tornado mais potente apenas depois de investigar as pinturas de Cézanne:

Ich war heute wieder bei seinen Bildern [...]. [...] Man merkt auch, von Mal zu Mal
besser, wie notwendig es war, auch noch über die Liebe hinauszukommen; es ist ja
natürlich, daß man jedes dieser Dinge liebt, wenn man es macht: zeigt man das aber,
so macht man es weniger gut; man beurteilt es, statt es zu sagen. Man hört auf,
unparteiisch zu sein; und das Beste, die Liebe, bleibt außerhalb der Arbeit, geht
nicht in sie ein, restiert unumgesetzt neben ihr: so entstand die Stimmungsmalerei
(die um nichts besser ist als die stoffliche). Man malte: ich liebe dieses hier; statt zu
malen: hier ist es. Wobei denn jeder selbst gut zusehen muß, ob ich es geliebt habe.
Das ist durchaus nicht gezeigt, und manche werden sogar behaupten, da wäre von
keiner Liebe die Rede. So ohne Rückstand ist sie aufgebraucht in der Aktion des

226 “[...] o ideal de um olhar objetivo [...]." (Tradução nossa).

227 "Se eu voltasse para vocês, com certeza também veria de modo novo e diferente a exuberância do pântano e da urze, o verde-claro suspenso dos prados e as bétulas [...].” (RILKE, 2006, p. 61, grifo nosso).

228 “[...] é verdade que essa transformação, posto que já a vivenciei e compartilhei por completo, trouxe à tona uma parte do Livro das Horas; contudo, a natureza era para mim, então, um ensejo geral, uma evocação, um instrumento em cujas cordas minhas mãos se reconheciam; eu ainda não sentava diante dela; me deixava levar pela alma que dela emanava; ela incidia sobre mim com sua vastidão, com sua grande e exagerada existência, como o profetizar vinha a Saul; exatamente assim. Eu caminhava ao redor e via, mas não via a natureza, e sim a história que ela me inspirava. Teria aprendido muito pouco, naquela época, diante de Cézanne e de Van Gogh." (RILKE, 2006, p. 61-62). 
Machens. Dieses Aufbrauchen der Liebe in anonymer Arbeit, woraus so reine Dinge entstehen, ist vielleicht noch keinem so völlig gelungen wie dem Alten [...]. ${ }^{229}$ (RILKE, 1996, p. 616, grifos do autor).

A abordagem de tratar a natureza como pretexto para evocação (Kunst-Vorwand) é a atitude que Rilke chama, aqui, de julgar (beurteilen), que se opõe à atitude de dizer (sagen), apenas, objetivamente. A primeira é análoga a pintar o sentimento do artista, e mostrar, por exemplo, que ele ama determinada coisa ("ich liebe dieses hier"); a segunda, a apenas pintar o objeto, de forma objetiva, e mostrar o que ele é ("hier ist es"). É interessante notar que Rilke não fala de sentimentos no sentido geral (Gefühle), mas de amor (Liebe). E Rilke não diz que o pintor deve ocultar esse amor, ou tentar suprimí-lo, mas sim, esgotá-lo (aufbrauchen); se colocado no objeto a ser pintado, o amor se torna limitante, porque impõe o sentimento antes da representação, que a condiciona. No trabalho anônimo, ou impessoal, o sentimento do artista é retirado da representação e canalizado no processo - por esse viés, o trabalho de representar objetivamente o que se vê é, de certo modo, um trabalho amoroso, é uma disposição em focar completamente no outro, na representação do objeto, e não em si mesmo.

"Wie ein Hund hat er davorgesessen und einfach geschaut, ohne alle Nervosität und Nebenansicht." 230 (RILKE, 1996, p. 614) - assim observa Mathilde Vollmoeller, a amiga que Rilke convida a acompanhá-lo ao Salão, diante das pinturas de Cézanne. Aprender a ver demanda uma determinação para sentar diante do objeto e olhar para ele: "Claro que esse dom se conquista pelo exercício, e não é em alguns meses [...]. [...] precoce ou tardia, espontânea ou formada no museu, sua visão em todo caso só aprende vendo, só aprende por si mesma." (MERLEAU-PONTY, 2015, p. 22-23). Cézanne exercitou sua visão de maneira incansável, e Rilke ateve-se a essa obstinação, retomando o ideal do trabalho constante formado a partir de Rodin. Rilke ressalta o caráter de trabalho associado ao exercício constante do olhar objetivo, e afirma que, agora que percebe que aprendeu a ver de uma maneira nova e diferente,

\footnotetext{
229 "Hoje, estive de novo olhando seus quadros [...]. [...] Nota-se também, cada vez melhor, como era necessário ir ainda além do amor; é mesmo natural que amemos cada uma destas coisas; mas se mostramos isso, amamos menos; julgamos, em vez de dizer. Deixamos de ser imparciais; e o melhor, o amor, permanece fora do trabalho, não entra nele, sobra, intransponível, a seu lado: assim nasceu a pintura de emoções (que não é melhor em nada do que a objetiva). Pinta-se: eu amo tal coisa; em vez de se pintar: aqui está tal coisa. Para que cada um tenha de ver se a amei. Isto não é mostrado de modo algum, e muitos chegarão a ver que ali não se fala de amor. Por ele ter sido consumido, sem sobras, na ação do fazer. Este consumir do amor no trabalho anônimo, de onde resultam coisas tão puras, talvez ninguém o tenha conseguido tão plenamente quanto o velho pintor [...]." (RILKE, 2006, p. 62-63, grifos do autor).

230 "Ele sentou aí na frente como um cão e simplesmente observou, sem estar nervoso e sem segundas intenções.” (RILKE, 2006, p. 60).
} 
Daran, wieviel Cézanne mir jetzt zu tun gibt, merk ich, wie sehr ich anders geworden bin. Ich bin auf dem Wege, ein Arbeiter zu werden, auf einem weiten Wege vielleicht und wahrscheinlich erst bei dem ersten Meilenstein; aber trotzdem, ich kann schon den Alten begreifen, der irgendwo weit vorne gegangen ist, allein [...]. ${ }^{231}$ (RILKE, 1996, p. 616).

O poeta aspira ter a mesma dedicação inabalável dos dois artistas, mas não acredita que ela deva se originar da obrigação: "Dazu muß man kommen und, das fühl ich wohl, nicht mit Zwang. Aus Einsicht, aus Lust, aus Nichtaufschiebenkönnen, in Anbetracht des vielen, was zu machen ist. Ach, daß man nicht Erinnerungen hätte an Nichtgearbeitethaben [...]."232 (RILKE, 1996, p. 603). O exercício do olhar e a criação artística são trabalhos exigentes, que demandam tempo, disposição, paciência. Mas Rilke acredita que ele deve estar associado ao prazer e à vontade - é a dimensão amorosa do trabalho artístico, que tem no sentimento do artista não mais o material de seu trabalho, mas seu combustível.

Nas poucas cartas em que tratou de sua pintura, Cézanne defendeu - como Rodin também o fez - que o trabalho artístico deveria se basear estritamente na natureza, e afirmou repetidas vezes que o trabalho feito ao ar livre seria sempre necessariamente melhor do que aquele executado dentro do ateliê: "Para fazer progressos, só através da natureza, e o olho se educa no contato com ela. Torna-se concêntrico à custa de observar e trabalhar." (CÉZANNE apud CHIPP, 1999, p. 17); “[...] acredito no desenvolvimento lógico do que vemos e sentimos através do estudo direto da natureza [...].” (CÉZANNE apud CHIPP, 1999, p. 19). Também como Rodin, ele foi um solitário e dedicou sua vida inteiramente ao trabalho. Argan afirma que "Cézanne renunciou a ter uma vida para realizar sua obra, ou melhor, fez da obra sua vida." (ARGAN, 2010, p. 109); Merleau-Ponty diz que "A pintura foi seu mundo e sua maneira de existir.” (MERLEAU-PONTY, 2015, p. 125). Mas, ao contrário do escultor, Cézanne esteve sempre insatisfeito ${ }^{233}$ com seus resultados e até muito próximo de sua morte

\footnotetext{
231 "Por isso, por Cézanne ter tanto a ver comigo agora, noto como me tornei diferente. Estou no caminho de me tornar um trabalhador, em um longo caminho, talvez, e provavelmente só nas primeiras milhas; mas, apesar disto, já posso compreender o velho homem que foi a algum lugar distante, lá na frente, sozinho [...].” (RILKE, 2006, p. 62).

232 “Temos de chegar a este ponto e, eu bem o sinto, não por obrigação. Pelo discernimento, pelo prazer, pelo não-poder-adiar, considerando o quanto está por fazer. Ah, que não houvesse lembranças agradáveis de não ter trabalhado." (RILKE, 2006, p. 40).

233 “A biografia sem acontecimentos de Cézanne ajuda a entender sua pintura [...]. Cézanne renunciou a ter uma vida para realizar sua obra, ou melhor, fez da obra sua vida. Com posses suficientes para viver de seus recursos, isolou-se em sua casa na Provença; logo renunciou também às esporádicas estadas em Paris, mantendo apenas raros contatos com os amigos mais caros, Monet, Pissarro, Renoir. Mas também não permitia que interferissem em seu trabalho; trabalhava incansavelmente, com método, consciente da enorme importância do que fazia, e, no entanto, sempre insatisfeito." (ARGAN, 2010, p. 109).
} 
lamentou a lentidão com que desenvolvia sua pintura. Merleau-Ponty cita uma carta de 1906, escrita um mês antes de morrer, na qual o pintor manifestou suas expectativas: "Parece-me agora que sigo melhor e que penso com mais exatidão na orientação de meus estudos. Chegarei à meta tão buscada e há tanto tempo perseguida? Estudo sempre a partir da natureza e parece-me que faço lentos progressos." (CÉZANNE apud MERLEAU-PONTY, 2015, p. 125); em 1904, escreveu a Émile Bernard: "Procedo muito lentamente, uma vez que a natureza se oferece a mim muito complexa; e os progressos a serem feitos são incessantes." (CÉZANNE apud CHIPP, 1999, p. 16).

A inconstância do aperfeiçoamento de Cézanne da réalisation - ou Dingwerdung - em sua obra, atestada em sua correspondência pessoal, pode também ser notada nas próprias pinturas, como mostra Mathilde Vollmoeler a Rilke:

\begin{abstract}
Und sie sagte noch sehr Gutes in Bezug auf seine Arbeitsart (die man an einem unvollendeten Bilde absieht). "Hier", sagte sie, auf eine Stelle zeigend, "dieses hat er gewußt, und nun sagt er es (eine Stelle an einem Apfel); nebenan ist es noch frei, weil er das noch nicht gewußt hat. Er machte nur, was er wußte, nichts anderes." ${ }^{234}$ (RILKE, 1996, p. 614).
\end{abstract}

Cézanne fez apenas o que sabia - quando não conseguiu resolver seu problema de representação, deixou a pintura inacabada, revelando, assim, seu processo de trabalho e suas limitações. Porém, um dos aspectos do processo criativo do pintor destacado por Rilke é a recusa em explicar suas ideias ao público. Ele preferia trabalhar de forma reservada até que acreditasse ter conseguido realizar plasticamente seus objetivos, de forma que suas ideias estariam visíveis na própria pintura, e teriam assim mais chances de serem compreendidas. Em uma das primeiras cartas, datada de 24 de junho de 1907, Rilke defende que na criação artística é preciso arriscar-se, lançar-se até o fim em uma investigação e, com isso, colocar-se a perigo. Por esse viés, o trabalho do artista se tornaria intensamente pessoal e, por esse motivo, o artista se veria impelido a não revelar seu processo até que sua intenção estivesse visível na obra (cf. RILKE, 1996, p. 594). Essa seria uma maneira de evitar que o público compreendesse erroneamente um trabalho ainda em desenvolvimento, e que o processo de criação não sofresse interferência de críticas, comentários ou demandas por explicação antes mesmo que o artista tivesse conseguido investigar e desenvolver a fundo suas ideias. Daí decorre a necessidade da solidão, que era para Rilke uma condição indispensável para seu

\footnotetext{
234 "E [ela] ainda disse muitas outras coisas boas em relação à sua maneira de trabalhar (que se vê em um quadro inacabado). 'Aqui', disse ela, mostrando determinado ponto, 'é algo que ele soube, e agora diz (determinado ponto em uma maçã); ao lado está vazio porque ele ainda não sabia. Ele fez apenas o que sabia, nada mais.”’ (RILKE, 2006, p. 60).
} 
trabalho de criação - para ele, a obra só deveria vir à público quando o próprio artista se sentisse seguro de ter atingido seus objetivos estéticos.

A carta de 28 de junho mostra que o poeta tampouco acreditava que o artista devesse elaborar considerações sobre sua obra que fossem externas a ela própria: as ideias do artista deveriam ser reveladas estritamente dentro da obra, nas soluções plásticas usadas para executá-la. Rilke dá o exemplo de Rodin:

\begin{abstract}
Aber ich weiß davon noch nichts, und daß Rodin nicht "nachdenkt", sondern innerhalb der Arbeit bleibt: innerhalb des Erreichbaren, das haben wir ja gerade als seinen Vorzug empfunden, als seinen demütigen, geduldigen, ins Wirkliche gestellten Weg: und ich hab noch keinen anderen Glauben, um ihn an die Stelle dieses Glaubens zu stellen. Man kann nur im "Gekonnten" bleiben in der Kunst, und dadurch, daß man darin bleibt, nimmt es zu und führt immer wieder über einen hinaus. Die "letzten Ahnungen und Einsichten" nähern sich nur dem, der in der Arbeit ist und bleibt, mein'ich, und der, der sie von ferne bedenkt, bekommt keine Macht über sie. ${ }^{235}$ (RILKE, 1996, p. 596).
\end{abstract}

Há uma ênfase no trabalho e na recusa em explicar as intenções, bem como um favorecimento do inconsciente. Essa atitude parece revelar uma crença de que, se o artista conseguir chegar à realização da materialidade do objeto na obra de arte (no caso de Cézanne, por exemplo, seria a Dingwerdung) - e essa confirmação da consumação da criação só pode ser dada pelo próprio artista, que é quem pensou o trabalho da concepção à execução - então a obra de arte se tornaria autônoma, e passaria a prescindir de explicações, pois nesse caso seria possível ao público acessar nela mesma as ideias do artista. Além disso, Rilke escreve, meses depois, que:

Der Maler dürfte nicht zum Bewußtsein seiner Einsichten kommen (wie der Künstler überhaupt): ohne den Umweg durch seine Reflexion zu nehmen, müssen seine Fortschritte, ihm selber rätselhaft, so rasch in die Arbeit eintreten, daß er sie in dem Moment ihres Übertritts nicht zu erkennen vermag. ${ }^{236}$ (RILKE, 1996, p. 628).

Rilke defende a ideia de que os processos - e os progressos - na pintura permanecem inconscientes, ou seja, enigmáticos para o próprio artista. Por esse motivo, um artista que escreve a respeito de seu próprio trabalho (como era o caso de Van Gogh) seria, na visão de Rilke, um artista menor, ao contrário de um artista que se recusa a tentar escrever sobre sua

235 "Mas disto nada sei, só que Rodin não elabora 'reflexões', e sim permanece dentro de seu trabalho, ou seja, dentro do alcançável, e foi isto, precisamente, o que experimentamos como sua primazia, como seu caminho humilde, paciente e assentado no real: e não tenho ainda nenhuma outra crença para pôr no lugar desta. Na arte, só podemos permanecer na força de quem 'pode' e, pelo fato de permanecermos aí, esta força cresce e sempre volta a nos ultrapassar. As 'últimas suspeitas e descobertas' só se aproximam daquele que vive no seu trabalho e nele permanece, pelo meu entender, e aquele que o observa de longe não adquire poder algum sobre ele." (RILKE, 2006, p. 28-29).

236 “O pintor não devia alcançar a consciência de suas considerações (como o artista em geral): sem tomar o atalho da sua reflexão, seus progressos, enigmáticos para ele mesmo, devem se impor tão rápido no trabalho, que, ao passarem, ele não poderia reconhecê-los.” (RILKE, 2006, p. 81). 
poética - como, por exemplo, Cézanne (cf. RILKE, 1996, p. 628). Apesar de se referir à palestra de Rilke sobre Rodin, no caso das cartas sobre Cézanne também se aplica a observação de Hoffmann de que "Rilke modelliert in seinem Vortrag ein produktionsaesthetisches wie anthropologisches Ideal, das anti-intellektuell ausgerichtet ist und dem Unbewussten stets den Vorzug vor dem Bewussten gibt." ${ }^{237}$ (HOFFMANN, 2010, p. 549). A elaboração intelectual, para Rilke, cria obstáculos para os processos artísticos, ao invés de complementá-los, e impede a comunicação direta entre o objeto e a visão ${ }^{238}$ (cf. STRATHAUSEN, 2003, p. 198-199).

Cézanne se baseava na sensação visual e não procurava criar uma abstração a partir dela, e sim compreendê-la na pintura. "Seus esforços são inteiramente dedicados a manter a sensação viva durante um processo analítico de pesquisa estrutural, que certamente é um processo do pensamento [...].” (ARGAN, 2010, p. 110). Sua pintura é uma longa pesquisa; de acordo com Argan, para Cézanne a pintura “[...] era um modo insubstituível de investigação das estruturas mais profundas do ser, uma pesquisa ontológica, uma espécie de filosofia.”, e "Em sua pintura nada é invenção, tudo é pesquisa." (ARGAN, 2010, p. 110). A busca de Cézanne em conciliar sensação e pensamento na pintura faz com que sua obra tenha o caráter de uma extensa pesquisa da sensação visual. Tanto Merleau-Ponty quanto Argan reforçam que a pintura de Cézanne não expressa um pensamento formulado previamente: ele ocorre no momento da experiência com o objeto real, da observação. Ambos, pensamento e experiência, se fundem em sua pintura, que assim atingiria o objetivo de representar como a impressão visual opera na consciência ${ }^{239}$. Segundo Argan, justamente por compreender que sua filosofia só poderia ser expressada na pintura, Cézanne decidiu trabalhar sozinho, e cita uma carta escrita pelo pintor a Octave Maus em 1889, na qual diz “[...] eu havia resolvido trabalhar em silêncio, até o dia em que me sentisse capaz de defender teoricamente o resultado de minhas experiências.” (cf. ARGAN, 2010, p. 111; CÉZANNE apud CHIPP, 1999, p. 14). E, ainda que ele estivesse insatisfeito com seu trabalho até a morte, Argan argumenta - em

\footnotetext{
237 "Rilke modelou em sua palestra uma estética de produção como um ideal antropológico, que tem orientação anti-intelectual e que prefere o inconsciente ao consciente.” (Tradução nossa).

${ }^{238}$ De acordo com Strathausen, essa separação entre discurso intelectual e linguagem artística era comum entre artistas e intelectuais na virada do século XX (cf. STRATHAUSEN, 2003, p. 198).

239 "Se há aí uma filosofia, não é, porém, uma filosofia que procede por silogismos, mas se efetua junto com a experiência viva e atual da realidade efetuada pela consciência. O modo de fundir e estabelecer uma identidade entre a experiência (a sensação) e o pensamento é a pintura: o único que não só permite acompanhar a transformação, como também transforma concretamente a impressão sensorial fugidia, quase inapreensível, em pensamento concreto, vivido, de modo a realizar a consciência em sua totalidade." (ARGAN, 2010, p. 111).
} 
consonância com Merleau-Ponty - que a pintura de Cézanne, por propor uma teoria decorrente da obra, e não anterior a ela, deu uma importante contribuição à filosofia moderna, que “[...] não é, nem quer ser, senão uma reflexão sobre a experiência em seu realizar-se, ou mesmo o seu realizar-se à luz da consciência [...].” (ARGAN, 2010, p. 111).

Essa disposição de Cézanne para dedicar-se ao trabalho em silêncio (e na solidão) e procurar transpor a sensação visual para a pintura sem procurar elaborar suas intenções verbalmente é louvada por Rilke. É preciso ressaltar, no entanto, que em grande medida o projeto estético que dá origem aos Neue Gedichte é - como vimos até aqui - extensamente elaborado por Rilke em textos de diferentes naturezas antes e depois da concretização dos Neue Gedichte. Pode-se argumentar que isso se dá pelo fato de que Rilke seja um escritor e estudioso, e mesmo que algumas dessas elaborações foram feitas na forma de trabalhos encomendados (como é o caso da monografia sobre Rodin), mas é curioso que, além dos escritos estéticos, Rilke leva adiante ainda a escrita de um romance no qual leva seu personagem - também poeta - a elaborar o mesmo projeto estético e a enfrentar uma dificuldade semelhante à sua: como produzir a partir da experiência do olhar quando seu meio de criação é a linguagem?

\subsection{Die Aufzeichnungen des Malte Laurids Brigge como texto estético programático}

O romance de Rilke, Die Aufzeichnungen des Malte Laurids Brigge, possui, como visto no primeiro capítulo desta dissertação, passagens marcadamente programáticas. À luz da análise de textos sobre arte que Rilke compôs entre 1898 e 1907 - portanto antes de terminar de redigir as Aufzeichnungen des Malte Laurids Brigge, que foram escritas entre 1904 e 1910 -, buscaremos aprofundar e ampliar a leitura do romance como texto programático. Faremos isso traçando algumas relações entre o projeto estético do personagem e as reflexões sobre arte de Rilke. Desta forma, pretendemos argumentar que o romance pode ser lido pelo menos de duas maneiras: como texto autobiográfico no qual Rilke redefine a sua vocação de poeta, e como texto estético-teórico no qual o autor esboça um programa para a criação poética e artística.

Primeiro, retomemos alguns dos pontos principais da análise feita no primeiro capítulo. Logo nas páginas iniciais do romance, na quarta, quinta e décima quinta anotações, Malte faz uma série de afirmações, ligadas entre si, que podem ser entendidas como o cerne 
de seu projeto estético. A primeira delas é "Ich lerne sehen."240 (RILKE, 1982, p. 10), reforçada na anotação seguinte: "Habe ich es schon gesagt? Ich lerne sehen - ja, ich fange an. Es geht noch schlecht. Aber ich will meine Zeit ausnutzen."241 (RILKE, 1982, p. 11). Malte não explica o que quer dizer com essa asserção, apenas que, com esse novo processo de aprendizado, começa também a perceber que possui uma interioridade que desconhecia até então. Dorothea Lauterbach afirma que ao leitor só é possível depreender o que seria essa capacidade que Malte começa a aprender a partir do que ela não é:

\begin{abstract}
Nur andeutungsweise gibt Rilke zu verstehen, wie dieses Sehen und das ihm zugehörige Bewußtsein beschaffen sein könnte. Expliziert wird nur, was es nicht ist: Dieses 'neue' oder 'andere' Sehen ist als Wahrnehmungsvermögen Maltes offenbar nicht an die Ratio gekoppelt, ist kein 'wiedererkennendes' Sehen, das sich an tradierten Deutungsmustern orientiert, hat keine Zuträgerfunktion für eine Objektivierung des Gesehenen. Es mündet in eine Art innere Erfahrung, die nicht ins Bewußtsein (zurück) zu führen scheint, zumindest nicht direkt, und die sich damit einer rational wertenden Kontrollinstanz entzieht. Erst im Kontext des ganzen Buches wird evident, daß es sich dabei um einen Aspekt einer Lebenshaltung handelt, die in Intuition und Erleben einen Ratio mindestens gleichwertigen Weltzugangs-Modus sieht. ${ }^{242}$ (LAUTERBACH, 2013, p. 323, grifo da autora).
\end{abstract}

Aprender a ver (sehen lernen) não significa aqui aprender a reconhecer (“wiedererkennen") os objetos a partir de padrões ou modelos pré-estabelecidos. De acordo com esse raciocínio, o olhar que Malte está aprendendo é o que não objetifica aquilo que se vê, e sim procura lançar um olhar despido de pré-concepções ao objeto. A conceituação do novo olhar de Malte feita por Lauterbach se aproxima do contraponto que Merleau-Ponty faz entre o olhar da ciência cartesiana e o olhar do artista:

A ciência manipula as coisas e renuncia habitá-las. Estabelece modelos internos delas e, operando sobre esses índices ou variáveis as transformações permitidas por sua definição, só de longe em longe se confronta com o mundo real. Ela é, sempre foi, esse pensamento admiravelmente ativo, engenhoso, desenvolto, esse parti pris de tratar todo ser como "objeto em geral", isto é, ao mesmo tempo como se ele nada fosse para nós e estivesse no entanto predestinado aos nossos artifícios. (MERLEAU-PONTY, 2015, p. 15)

240 "Estou aprendendo a ver." (RILKE, 1979, p. 6).

241 "Será que já contei isso? Estou aprendendo a ver. Sim, estou começando. Ainda o faço mal. Mas quero aproveitar bem meu tempo.” (RILKE, 1979, p. 6-7).

242 “Apenas sugestivamente Rilke nos dá a entender como essa visão e a consciência correspondente podem ser criadas. Fica explícito apenas, o que ela não é: essa 'nova' ou 'diferente' visão, como percepção de Malte, evidentemente não está ligada à razão, não é uma visão que 'reconhece', que seja orientada por modelos interpretativos, não tem função informativa para uma objetificação do que é visto. Ela se desdobra em uma espécie de experiência interior, que não parece voltar à consciência, ao menos não diretamente, e que por isso elimina uma autoridade racional e julgadora. No contexto de todo o livro fica evidente que se trata de um aspecto de um modo de vida, que vê na intuição e na vivência uma abordagem ao menos equivalente à razão." (Tradução nossa). 
Na ciência, os objetos e seres são categorizados e analisados a partir do quanto diferem ou se assemelham àquele que é tomado como exemplar de sua categoria, por meio de procedimentos que retiram sistematicamente sua individualização. Uma das diferenças na abordagem do artista é que nela, o modo de pensamento não é de sobrevoo, ele "emprega seu corpo" (VALÉRY apud MERLEAU-PONTY, 2015, p. 18). "Basta que eu veja alguma coisa para saber juntar-me a ela e atingi-la, mesmo se não sei como isso se produz na máquina nervosa. Meu corpo móvel conta com o mundo visível, faz parte dele, e por isso posso dirigilo no visível.” (MERLEAU-PONTY, 2015, p. 18). Lauterbach, conclui que o aprendizado do olhar não é o mesmo que formular um conhecimento a ser aplicado em determinados casos, como acontece na ciência; aprender a ver significa, antes, aprender uma nova maneira de estar no mundo, de olhar para o mundo.

Esse entendimento complementa o de August Stahl, que afirma: "Mit 'sehen' bezeichnet [Rilke] eine Haltung, die durch Verzicht auf das subjektive Element sich ganz dem Objektiven des Außen zuwendet."243 (STAHL, 1996, p. 912). O novo olhar não categoriza o que é visto, mas também, por outro lado, não identifica o objeto a partir da subjetividade de quem olha. O olhar objetivo que Malte está a aprender, portanto, significa olhar para o objeto procurando apreendê-lo pelo que ele é, não pelo que se supõe que ele seja, e nem pelo que se sente a respeito dele. Ora, essa é a definição do olhar direto, objetivo ("das einfache Schauen"), da objetividade ("Sachlichkeit") que Rilke desenvolveu a partir das obras de Rodin e Cézanne entre os anos de 1902 e 1907. Ambos os artistas tinham o olhar objetivo como fundamento de seus processos de criação. E é o que faz Malte, na terceira passagem programática do romance, quando diz: "Ich glaube, ich müßte anfangen, etwas zu arbeiten, jetzt, da ich sehen lerne."244 (RILKE, 1982, p. 21). Apenas nessa anotação fica claro para o leitor que o personagem também é poeta, e que o trabalho a ele que se refere é a escrita. Nessa anotação, Malte revê sua produção literária anterior - de quando ainda não começava a aprender a ver - e desenvolve seu projeto para dali em diante.

Segundo ele, versos escritos na juventude não têm grande valor, "Denn Verse sind nicht, wie die Leute meinen, Gefühle (die hat man früh genug), - es sind Erfahrungen."245

\footnotetext{
243 “Com 'ver', ele [Rilke] designa uma atitude que, através da renúncia do elemento subjetivo, volta-se totalmente para a objetividade do exterior." (Tradução nossa).

244 “Acho que eu deveria começar a fazer algo, a trabalhar, agora que estou aprendendo a ver.” (RILKE, 1979, p. 14).

245 "Pois versos não são, como as pessoas imaginam, sentimentos (a esses, temos cedo demais) - são experiências.” (RILKE, 1979, p. 14).
} 
(RILKE, 1982, p. 21). Em seguida, prescreve uma série de experiências que são necessárias, que qualquer aspirante a poeta, deve (“man mи $\beta$ ”) observar. A respeito dessa passagem, Stahl afirma: "Die folgenden Zeilen entwerfen Rilkes Programm der 'Sachlichkeit' und der Neuen Gedichte, so wie es vor allem in den beiden großen Requiem dichterisch formuliert ist."246 (STAHL, 1996, p. 920). A escrita é problematizada no texto à luz do tema do olhar objetivo: Rodin e Cézanne o exercitaram para produzir esculturas e pinturas, respectivamente, Malte como Rilke - viu nesse aprendizado uma possibilidade de redefinir sua atividade de escritor e poeta. Entretanto, a objetividade não se limita a ter essas experiências, ou ver essas situações, e lembrar-se delas:

Und es genügt auch noch nicht, daß man Erinnerungen hat. Man muß sie vergessen können, wenn es viele sind, und man muß die große Geduld haben, zu warten, daß sie wiederkommen. Denn die Erinnerungen selbst sind es noch nicht. Erst wenn sie Blut werden in uns, Blick und Gebärde, namenlos und nicht mehr zu unterscheiden von uns selbst, erst dann kann es geschehen, daß in einer sehr seltenen Stunde das erste Wort eines Verses aufsteht in ihrer Mitte und aus ihnen ausgeht. ${ }^{247}$ (RILKE, 1982, p. 21-22, grifo do autor).

"Namenlos": surge aqui, por trás da lista de experiências necessárias, a real finalidade do aprendizado do olhar, e porque Malte diz que deve começar a trabalhar ("etwas zu arbeiten"), e não a escrever ("etwas zu schreiben"). Estão em questão aqui os ideais da dedicação total ao trabalho e da Selbstvergessenheit de Rodin. Apenas quando o poeta entregar-se inteiramente ao exercício constante de olhar - entendendo-o como trabalho - e conseguir olhar para o mundo de maneira objetiva, sem deixar que seus sentimentos atravessem a impressão provocada pelo que está sendo observado, e for capaz de esquecer-se de si mesmo, tornandose pura impressão daquilo que observa ("Blut, Blick und Gebärde"), nesse momento, segundo Malte, ele será capaz de escrever bons versos.

Mas o que é saber olhar? Seria possível alcançar a total objetividade da visão? Merleau-Ponty diz que, se o corpo do artista está necessariamente implicado no mundo, no qual ele transita e para o qual olha, ele não pode olhar o mundo como se estivesse fora dele, mas apenas se movimentando dentro dele. Existe também, no próprio corpo, uma relação de reciprocidade: o corpo é vidente e visível, "Ele, que olha todas as coisas, pode também se olhar, e reconhecer no que vê então o 'outro lado' de seu poder vidente.” (MERLEAU-

\footnotetext{
246 “Nas linhas seguintes, Rilke esboça o programa da 'Sachlichkeit' ['objetividade'] e dos Neue Gedichte, como é formulado poeticamente sobretudo nos grandes poemas Requiem [de Das Buch der Bilder].” (Tradução nossa).

247 “E também não basta ter recordações. É preciso saber esquecê-las, quando são muitas, e ter a grande paciência de esperar que retornem por si. Pois as lembranças em si ainda não o são. Só quando se tornarem sangue em nós, olhar e gesto, sem nome, não mais distinguíveis de nós mesmos, só então pode acontecer que numa hora muito rara se erga do meio delas a primeira palavra de um poema." (RILKE, 1979, p. 15).
} 
PONTY, 2015, p. 19). Isso significa que esse corpo pode, além de ser visto, ver-se vendo, ver-se em contato com o mundo. "Visível e móvel, meu corpo conta-se entre as coisas, é uma delas, está preso no tecido do mundo, e sua coesão é a de uma coisa. Mas, dado que vê e se move, ele mantém as coisas em círculo a seu redor, elas são um anexo ou um prolongamento dele mesmo [...].” (MERLEAU-PONTY, 2015, p. 20). Esse corpo que vê o mundo de dentro, vê a si mesmo e é visto, enquanto transita por esse mundo, ao qual está intrinsecamente ligado, é, ao mesmo tempo, individual. E, tendo a si mesmo como centro da sua relação com o mundo e com os outros corpos, esse corpo, quando volta seu olhar para outros corpos, não os categoriza ou generaliza: são outros seres individuais, que têm a si mesmos como centro da própria experiência de mundo. Ao contrário do que ocorre na ciência, esse corpo se confronta com o "mundo real" - a individuação dos outros corpos - o tempo todo.

Essa atitude de olhar e contemplar o que torna o outro individual, Merleau-Ponty resume da seguinte maneira: "A visão não é um certo modo do pensamento ou presença em si: é o meio que me é dado de estar ausente de mim mesmo, de assistir por dentro a fissão do ser, ao término da qual somente me fecho sobre mim.” (MERLEAU-PONTY, 2015, p. 51). Mas a possibilidade de ausentar-se de si apresentada pela visão encontra um limite, que é o de sua própria origem: “[...] a visão é tomada ou se faz do meio das coisas, lá onde persiste, como a água-mãe no cristal, a indivisão do senciente e do sentido." (MERLEAU-PONTY, 2015, p. 20). Por esse viés, o ideal da Sachlichkeit encontra esse fato impeditivo: mesmo que o artista treine seu olhar para evitar que ele seja atravessado por sua subjetividade, não poderia alcançar uma objetividade pura, pois seu olhar nasce necessariamente da imbricação de seu sentimento com o mundo: "Instrumento que se move por si mesmo, meio que inventa seus fins, o olho é aquilo que foi sensibilizado por um certo impacto do mundo e o restitui ao visível pelos traços da mão.” (MERLEAU-PONTY, 2015, p. 23, grifo do autor).

Nas Aufzeichnungen, Strathausen destaca o episódio em que o conde Brahe dita suas memórias para Abelone, narrado na anotação 44, como argumento de que a visão tem natureza subjetiva, que não pode ser objetivamente traduzida em linguagem (cf. STRATHAUSEN, 2003, p. 209). O estudioso aponta que, no momento em que o conde Brahe se frustra com a vagareza do processo de escrita, a escrita passa a ser tratada metaforicamente (cf. STRATHAUSEN, 2003, p. 208-209): “'Die Bücher sind leer', schrie der Graf mit einer wütenden Gebärde nach den Wänden hin, 'das Blut, darauf kommt es an, da muß man drin 
lesen können." 248 (RILKE, 1982, p. 122). De acordo com Strathausen, o conde sugere que, para ver o mundo, é preciso saber ler o corpo humano: "Seeing things means to look through bodies and read their entrails as a kind of language that dissolves the gaze within its flow and carries the reader along."249 (STRATHAUSEN, 2003, p. 209). Essa concepção não é diferente da ideia que Malte tem a partir do poema "Une charogne", de Baudelaire, discutida no primeiro capítulo desta pesquisa, de que se tratava de saber ver o elemento existencial oculto em cada ser, mesmo em uma carniça. Strathausen afirma que, para o conde Brahe, é possível ler o corpo - como acontece quando ele abre as mãos de Abelone como se fossem um livro (cf. RILKE, 1982, p. 124) - "[...] as the exterior of a pulsation energy that runs through it." 250 (STRATHAUSEN, 2003, p. 209), ou seja, como a parte visível, inscrita, do elemento existencial (“das Seiende”) e de sua história.

Ainda assim, no romance de Rilke, o personagem Malte parece ter em vista essa anulação total da subjetividade em sua escrita. Em uma das passagens mais emblemáticas das Aufzeichnungen, Malte discorre sobre diferentes lugares e situações vividos ou presenciados na cidade em um mesmo dia, mas detém-se no homem moribundo que havia capturado sua atenção em um café, o que o leva a refletir mais uma vez sobre sua própria situação. Ele se identifica com o sofrimento do homem, mas afirma que, ao contrário deste, ainda resiste. A ajuda à qual Malte se apega para não sucumbir à morte é a escrita. Ainda que ele sinta medo, que suas motivações se afastem dele, que o mundo tenha se tornado incompreensível para ele, ele deve escrever; e, uma vez que ele escreve também porque aprende a ver, seu destino é tornar-se anônimo no trabalho:

\begin{abstract}
Noch eine Weile kann ich das alles aufschreiben und sagen. Aber es wird ein Tag kommen, da meine Hand weit von mir sein wird, und wenn ich sie schreiben heißen werde, wird sie Worte schreiben, die ich nicht meine. Die Zeit der anderen Auslegung wird anbrechen, und es wird kein Wort auf dem anderen bleiben, und jeder Sinn wird wie Wolken sich auflösen und wie Wasser niedergehen. Bei aller Furcht bin ich schließlich doch wie einer, der vor etwas Großem steht, und ich erinnere mich, daß es früher oft ähnlich in mir war, eh ich zu schreiben begann. Aber diesmal werde ich geschrieben werden. Ich bin der Eindruck, der sich verwandeln wird. ${ }^{251} 252$ (RILKE, 1982, p. 47).
\end{abstract}

248 “-Os livros são coisas vazias - berrava o conde, fazendo um gesto de fúria em direção das paredes - o sangue, o sangue é que importa, é nele que se tem de poder ler.” (RILKE, 1979, p. 88).

249 "Ver coisas significa olhar através de corpos e ler suas entranhas como uma forma de linguagem que dissolve o olhar no seu fluxo e carrega o leitor junto." (Tradução nossa).

250 “[...] como o exterior de uma energia pulsante que corre por entre [o corpo].” (Tradução nossa).

251 "Por algum tempo ainda poderei escrever e dizer todas essas coisas. Mas virá um dia em que minha mão estará longe de mim, e, quando eu mandá-la escrever, escreverá palavras que eu não quero. Chegará o tempo de uma outra interpretação, não ficará palavra sobre palavra, cada significado se desfará como nuvens que se 
Essa parece ser uma espécie de fantasia da Selbstvergessenheit, em que Malte imagina que chegará ao ponto de olhar não só para o mundo, mas também para si mesmo, com o mais alto grau de distanciamento e objetividade.

No entanto, na origem do aprendizado do olhar objetivo e de seus propósitos relacionados a ele, está sua experiência subjetiva:

Wenn aber dieses alles möglich ist, auch nur einen Schein von Möglichkeit hat, dann muß ja, um alles in der Welt, etwas geschehen. Der Nächstbeste, der, welcher diesen beunruhigenden Gedanken gehabt hat, muß anfangen, etwas von dem Versäumten zu tun; wenn es auch nur irgend einer ist, durchaus nicht der Geeignetste: es ist eben kein anderer da. Dieser junge, belanglose Ausländer, Brigge, wird sich fünf Treppen hoch hinsetzen müssen und schreiben, Tag und Nacht. Ja, er wird schreiben müssen, das wird das Ende sein. ${ }^{253}$ (RILKE, 1982, p. 24-25).

Assim Malte estabelece sua tarefa: escrever dia e noite, agora que aprende a ver, para investigar as questões prementes de seu tempo. A maneira como Malte descreve a si mesmo diante dessa imensa tarefa guarda semelhança com a maneira como Rilke descreve o jovem Rodin diante da tarefa de buscar uma nova representação que se adequasse aos conflitos da Modernidade $^{254}$. É importante ressaltar que, como o Rodin retratado por Rilke em sua

desmancham em água. Com todo este medo, sou como alguém diante de algo grandioso, e lembro-me de que antigamente muitas vezes me sentia assim, antes de começar a escrever. Mas dessa vez eu serei escrito. Eu sou a impressão que quer se transpor." (RILKE, 1979, p. 32-33).

252 Segundo August Stahl, "Diese Stelle deutet Lorenz im Sinne einer 'Zurücknahme der Autor-Funktion aus dem Gestaltungsbereich subjektiver Autonomie'." (STAHL, 1996, p. 930). [“Essa passagem é interpretada por Lorenz com o sentido de uma 'anulação da função do autor no campo da formação da autonomia subjetiva'." (Tradução nossa).]

253 “Mas se tudo isso é possível, ao menos vagamente possível, então, por tudo que há de sagrado no mundo, algo tem de acontecer. O primeiro a ter esse pensamento inquietante precisa começar a fazer algo do que foi omitido; mesmo se for apenas um sujeito qualquer, talvez nem mesmo o mais indicado: simplesmente, não há outro melhor. Esse jovem estrangeiro insignificante, esse Brigge, terá de sentar-se num quinto andar e escrever, dia e noite: sim, terá de escrever, e este será o fim." (RILKE, 1979, p. 17).

254 "Hier war eine Aufgabe, groß wie die Welt. Und der vor ihr stand und sie sah, war ein Unbekannter, dessen Hände nach Brot gingen, in Dunkelheit. Er war ganz allein, und wenn er ein richtiger Träumer gewesen wäre, so hätte er einen schönen und tiefen Traum träumen dürfen, einen Traum, den niemand verstanden hätte, einen von jenen langen, langen Träumen, über denen ein Leben hingehen kann wie ein Tag. Aber dieser junge Mensch, der in der Manufaktur von Sèvres seinen Verdienst hatte, war ein Träumer, dem der Traum in die Hände stieg, und er begann gleich mit seiner Verwirklichung. Er fühlte, wo man anfangen mußte; eine Ruhe, die in ihm war, zeigte ihm den weisen Weg." (RILKE, 1996, p. 409). ["Aqui havia uma tarefa grande como o mundo. E aquele que diante dela se encontrava e a via era um desconhecido, cujas mãos buscavam trabalho, caminhando no escuro. Ele estava completamente sozinho e, se tivesse sido um verdadeiro sonhador, teria tido um belo e profundo sonho, um sonho que ninguém teria entendido, um daqueles longos, longos sonhos pelos quais pode passar uma vida inteira, como se fosse um único dia. Mas este jovem que obtinha o seu sustento na manufatura de Sèvres era um sonhador cujos sonhos impregnavam as suas mãos e ele imediatamente começou com a sua realização. Ele sentia onde era necessário começar; uma paz, que nele residia, mostrou-lhe o caminho do bom senso.” (RILKE, 2003, p. 21).] 
monografia, Malte também não tem um mestre que o oriente e ajude com seu novo aprendizado e a nova direção que seu trabalho começa a tomar. Parece haver aqui um ideal de autossuficiência do artista, a crença de que, através do estudo e do trabalho constantes, o artista pode, sozinho, vir a se tornar mestre de seu ofício, mesmo que comece de um lugar de anonimato e inexperiência. Ligado a esse ideal, está a ideia de trabalho artístico como missão - para Rodin e Malte, essa missão seria a de entregar-se obstinadamente à tarefa de preencher uma lacuna; no caso de Rodin, a tarefa é a representação escultórica do homem moderno, no de Malte, é buscar na escrita a resposta para as questões existenciais da Modernidade. Em ambos, o elemento fundamental da criação artística é o olhar objetivo, mas as concepções de quais sejam suas tarefas nascem necessariamente de suas experiências subjetivas na Modernidade.

Além disso, sem mestre, o aprendizado de Malte fica à mercê de sua própria sensibilidade e discernimento. Há, no romance, dois meios que se apresentam em diferentes momentos como possibilidades de ajuda nesse processo. O primeiro deles é a ideia de recuperar a infância. Em uma das primeiras anotações - a décima delas -, aparece uma indicação disso: nela, apesar da mudança de registro (começa na primeira pessoa, passa para a terceira e termina voltando para a primeira), fica claro que Malte está a refletir sobre sua própria condição em Paris - pobre, solitário, desgarrado de suas raízes -, quando vislumbra um possível atenuante:

Und man hat niemand und nichts und fährt in der Welt herum mit einem Koffer und mit einer Bücherkiste und eigentlich ohne Neugierde. Was für ein Leben ist das eigentlich: ohne Haus, ohne ererbte Dinge, ohne Hunde. Hätte man doch wenigstens seine Erinnerungen. Aber wer hat die? Wäre die Kindheit da, sie ist wie vergraben. Vielleicht muß man alt sein, um an das alles heranreichen zu können. Ich denke es mir gut, alt zu sein. ${ }^{255}$ (RILKE, 1982, p. 19).

O olhar infantil, naturalmente despido de preconceitos e julgamentos, para o qual tudo é novo, é o que mais se assemelha ao olhar da Sachlichkeit. No desenrolar da primeira parte do livro, Malte retoma diversas memórias de sua infância. O problema é que, com elas, seus antigos medos também voltam a aflorar: "Ich habe um meine Kindheit gebeten, und sie ist wiedergekommen, und ich fühle, daß sie immer noch so schwer ist wie damals und daß es

\footnotetext{
255 "E não se tem ninguém, anda-se pelo mundo com uma mala, um caixote de livros, no fundo sem qualquer curiosidade. Mas que vida é esta afinal? Sem casa, sem coisas herdadas, sem cães. Se ao menos se tivessem lembranças. Mas quem as tem? Se a infância estivesse aqui, mas está como que enterrada. Talvez seja preciso envelhecer para poder alcançar todas essas coisas. Acho que deve ser bom, envelhecer.” (RILKE, 1979, p. 13).
} 
nichts genützt hat, älter zu werden.”256 (RILKE, 1982, p. 56). Malte se frustra, pois recuperar a infância parece lhe trazer mais sofrimento do que consolo ou ajuda.

A outra possibilidade que aparece no romance, e esta parece contribuir mais efetivamente para o desenvolvimento de Malte, é a leitura. Podemos relacionar a importância da leitura aqui ao ideal da dedicação total ao trabalho. Essa dedicação se torna imperativa porque a criação artística não pode mais depender da arbitrariedade da inspiração; de modo análogo, a transmissão de sabedoria entre gerações, que tem um elemento circunstancial, também não é mais possível na Modernidade. A contrapartida da extinção da transmissão de experiência é a possibilidade de escolher as fontes de onde obter conhecimento, através dos livros. Nessa nova relação, a obstinação e o trabalho contínuo se fazem necessários porque o desenvolvimento do artista fica sob sua própria responsabilidade, em todos os sentidos. Nas anotações, Malte cita um grande número de autores, especialmente na segunda parte do romance, na qual o tema leitura é retomado com mais frequência. No romance, o tema da leitura se relaciona a outros, que nos interessa tratar aqui: além do aprendizado do olhar, há ainda o tema da solidão e o do amor.

Comecemos por uma anotação em que Malte cita um trecho do poema "A une heure du matin”, de Charles Baudelaire, que é parte do volume Le Spleen de Paris, de 1869. Tratase de uma longa anotação na qual Malte narra retrospectivamente uma série de eventos pelos quais passou em uma incursão pela cidade e que o perturbaram profundamente. No final do relato, é a última estrofe do poema que Malte cita, diretamente e em francês (cf. RILKE, 1982, p. 47-48), mas, aqui, nos parece interessante trazer também o início do poema para esta análise:

Enfin! seul! On n'entend plus que le roulement de quelques fiacres attardés et éreintés. Pendant quelques heures, nous posséderons le silence, sinon le repos. Enfin! la tyrannie de la face humaine a disparu, et je ne souffrirai plus que par moimême.

Enfin! il m'est donc permis de me délasser dans un bain de ténèbres! D'abord, un double tour à la serrure. Il me sembre que ce tour de clef augmentera ma solitude et fortifiera les barricades qui me séparent actuellement du monde.

Horrible vie! Horrible ville! [...]

Mécontent de tous et mécontent de moi, je voudrais bien me racheter et m'enorgueillir un peu dans le silence et la solitude de la nuit. Âmes de ceux que j'ai aimés, âmes de ceux que j'ai chantés, fortifiez-moi, soutenez-moi, éloignez de moi le mensonge et les vapeurs corruptrices du monde, et vous, Seigneur mon Dieu! accordez-moi la grâce de produire quelques beaux vers qui me prouvent à moi-

256 "Rezei pela minha infância e ela retornou; sinto que ainda é tão difícil como outrora, e que de nada adiantou envelhecer." (RILKE, 1979, p. 40). 
même que je ne suis pas le dernier des hommes, que je ne suis pas inférieur à ceux que je méprise!257 (BAUDELAIRE, 2009, p. 58-60).

Até essa anotação, sabe-se que Malte é solitário, mas essa condição parece ser decorrente do fato de ele ser pobre e estrangeiro. Com a citação do poema de Baudelaire, é acrescentada ao romance uma dimensão nova da solidão de Malte: de que ela seja voluntária.

Em seus primeiros textos estéticos, Rilke já insistia no ethos do artista como o solitário por excelência. Segundo Manfred Koch, no final do século XIX essa caracterização do artista como solitário era pouco original e estava ligada a um desprezo pela eficiência burguesa (cf. $\mathrm{KOCH}, 2013$, p. 482). Depois do contato com Rodin e com a obra de Cézanne, dois artistas que se retiraram das relações sociais para se dedicar inteiramente ao trabalho artístico, essa caracterização é reforçada, e a solidão passa a ser vista não mais apenas como a consequência de uma inabilidade em adequar-se à sociedade, mas como uma premissa necessária para a liberdade de criação do artista. É importante ressaltar que, para Rilke, a solidão não é sinônimo de alienação: ao mesmo tempo em que há uma busca pelo isolamento, também há uma atitude de atirar-se no mundo. Nas Aufzeichnungen, a solidão do protagonista parece ter esses dois aspectos, o contingente e o voluntário, e uma tensão entre o desejo de isolar-se e de adentrar o mundo. A lógica da cidade grande e de seus habitantes é, na primeira parte do livro, o objeto ao qual Malte dedica seu exercício da visão, e para isso ele caminha pela cidade e se imiscui à vida que nela fervilha. No entanto, o contato com as pessoas o agride como, por exemplo, quando ele encontra o grupo de foliões e um punhado de confetes atirado lhe causa a sensação de queimarem seu rosto (cf. RILKE, 1982, p. 43-44). Ele deseja distanciar-se das pessoas - o trecho do poema de Baudelaire aparece reproduzido como se fosse uma espécie de prece (cf. RILKE, 1982, p. 47-48). Ao mesmo tempo, Malte se tornou alguém que vive à margem da sociedade, um pária, que é reconhecido pelos demais párias que vagam pelas ruas da cidade como um semelhante (cf. RILKE, 1982, p. 36-38). A solidão do artista é levada às últimas consequências no romance, como se Rilke tivesse desejado compôr um personagem que, de certa forma está, ao mesmo tempo, dentro e fora do mundo - ele se

\footnotetext{
257 "Enfim! Só! Já não se ouve mais que o movimento de alguns fiacres retardados e estafados. Durante algumas horas, possuiremos o silêncio, se não o repouso. Enfim! Desapareceu a tirania da face humana, e já não sofrerei senão por mim mesmo.// Enfim! É-me então permitido repousar num banho de trevas! Primeiro, duas voltas na fechadura. Parece-me que girar a chave aumentará minha solidão e fortificará as barricadas que me separam atualmente do mundo.// Vida horrível! Cidade horrível! [...]// Descontente com todos e descontente comigo, gostaria de me redimir e me orgulhar um pouco, no silêncio e na solidão da noite. Almas daqueles que amei, almas daqueles que cantei, fortaleçam-me, sustenham-me, afastem de mim a mentira e os vapores corruptores do mundo. E vós, Senhor, meu Deus! Concedei-me a graça de produzir alguns poucos versos belos, que provem a mim mesmo que não sou o último dos homens, que não sou inferior àqueles que desprezo!" (BAUDELAIRE, 2009, p. 59-61).
} 
dedica a observar o mundo a partir da perspectiva de alguém que está dentro dele, mas que não compactua com a lógica e com as demandas da vida moderna e se mantém fora das relações sociais e interpessoais.

Algumas páginas adiante há mais uma menção ao poeta francês, na anotação que traz a designação "Ein Briefentwurf". Dirigindo-se a um destinatário não especificado, Malte faz uma reflexão sobre o poema "Une charogne", de Baudelaire, e sobre o conto "La legende de Saint Julien 1'Hospitalier", de Flaubert:

Erinnerst Du Dich an Baudelaires unglaubliches Gedicht "Une Charogne"? Es kann sein, daß ich es jetzt verstehe. Abgesehen von der letzten Strophe war er im Recht. Was sollte er tun, da ihm das widerfuhr? Es war seine Aufgabe, in diesem Schrecklichen, scheinbar nur Widerwärtigen das Seiende zu sehen, das unter allem Seienden gilt. Auswahl und Ablehnung giebt es nicht. Hälst Du es für einen Zufall, daß Flaubert seinen Saint-Julien-1'Hospitalier geschrieben hat? Es kommt mir vor, als wäre das das Entscheidende: ob einer es über sich bringt, sich zu dem Aussätzigen zu legen und ihn zu erwärmen mit der Herzwärme der Liebesnächte, das kann nicht anders als gut ausgehen. ${ }^{258}$ (RILKE, 1982, p. 62-63).

Como visto no primeiro capítulo desta pesquisa, nessa passagem Malte retoma o tema do olhar, afirmando que, agora que está aprendendo a ver, compreende o que motivou Baudelaire a escrever um poema focado em um tema repulsivo. Na carta de 19 de outubro de 1907, parte da compilação de cartas sobre Cézanne, Rilke escreve a Clara sobre a menção a esse poema nas Aufzeichnungen:

Ich mußte daran denken, daß ohne dieses Gedicht die ganze Entwicklung zum sachlichen Sagen, die wir jetzt in Cézanne zu erkennen glauben, nicht hätte anheben können; erst mußte es da sein in seiner Unerbittlichkeit. Erst mußte das künstlerische Anschauen sich so weit überwunden haben, auch im Schrecklichen und scheinbar nur Widerwärtigen das Seiende zu sehen, das, mit allem anderen Seienden, gilt. $^{259}$ (RILKE, 1996, p. 624, grifo do autor)

Rilke confirma, nessa carta, que "Une charogne" aparece no romance como um paradigma da objetividade (Sachlichkeit): é preciso olhar para todas as coisas, sejam elas repulsivas ou não; ao artista, não é dada a possibilidade de escolher o que ver.

258 “Lembras-te daquele inacreditável poema de Baudelaire, 'Une Charogne'? Talvez agora eu o entenda. Com exceção da última estrofe, ele estava certo. Que haveria ele de fazer, se aquilo lhe acontecia? Era tarefa dele ver, no meio daquelas coisas terríveis, entre aquelas coisas só aparentemente repulsivas, o que é, o que realmente conta entre tudo o que é. Não se permitem nem escolha nem rejeição. Julgas casualidade que Flaubert tenha escrito o seu Saint-Julien-l'Hospitalier? Parece-me que isto é o decisivo: que alguém se supere até conseguir deitar-se ao lado de um leproso e aquecê-lo com as noites de amor - isto só pode terminar bem." (RILKE, 1979, p. 44).

259 "Fui levado a pensar que, sem este poema, toda a evolução para o dizer objetivo, que agora acreditamos reconhecer em Cézanne, não teria por onde começar. Era preciso, primeiro, que ele estivesse ali com sua inexorabilidade. Era preciso, primeiro, que o olhar artístico ousasse, até o ponto de ver, também no horrendo e aparentemente só repugnante, o ente que é válido, como todos os outros entes." (RILKE, 2006, p. 75, grifo do autor). 
Além desse ponto, surge pela primeira vez, nessa passagem, a propósito de Flaubert, o componente do amor no trabalho criativo. Saint Julien l'Hospitalier, aquele que, em sua decisão de servir a todo e qualquer ente, deitou-se com um leproso para dar-lhe o calor de seu próprio corpo, é usado por Rilke como outro paradigma da Sachlichkeit, aprendido com Cézanne: "Dies sich-zu-dem Aussätzigen-Legen und alle eigene Wärme bis zu der Herzwärme der Liebesnächte, mit ihm teilen: dies muß irgendwann im Dasein eines Künstlers gewesen sein, als Überwindung zu seiner neuen Seligkeit."260 (RILKE, 1996, p. 624). Aqui Rilke retoma a ideia desenvolvida na carta de 13 de outubro daquele ano, analisada na seção anterior deste capítulo: ao invés de expressar o amor pelo objeto na obra, o artista deve levar esse sentimento para o processo criativo, consumi-lo no trabalho. No entanto, da mesma maneira que Rilke, através de Malte, traz a referência de "Une charogne" para argumentar que ao artista não é dada a possibilidade de escolher entre o que ver e o que não ver, a referência ao protagonista do conto de Flaubert aparece - na carta e no romance - para demonstrar que também essa atitude amorosa deve existir de modo incondicional.

O tema do amor é, com efeito, um dos aspectos mais importantes da segunda parte das Aufzeichnungen, e que se origina do tema da leitura. Entre as últimas anotações do livro, está uma longa rememoração de Malte de suas primeiras experiências de leitura na infância: "So ist mir klar geworden, daß ich nie ein richtiger Leser war." ${ }^{261}$ (RILKE, 1982, p. 156). Malte narra por que motivos ele se lança à leitura durante um verão em Ulsgaard, as dificuldades que teve em suas primeiras empreitadas com a leitura e como encerra seu afã tão abruptamente como começara. Nesse ínterim, ele se desentende com Abelone, única personagem que aparece em todo o romance (além de sua mãe) - e apenas através das rememorações do protagonista - com a qual fica subentendido que Malte teve uma relação mais estreita. Em determinado momento, pensando em se reconciliar com Abelone, Malte abre um volume que ela estava lendo anteriormente, uma compilação da correspondência entre Bettina von Arnim e Goethe. Abelone pede-lhe que leia em voz alta, mas apenas as cartas de Bettina, e não as respostas de Goethe. Abelone, impaciente, retira o livro das mãos

\footnotetext{
260 "Este deitar-se com o leproso e compartilhar com ele todo o calor próprio, até o das noites de amor: é isto que a existência de um artista deve ter experimentado, como superação para sua nova ventura." (RILKE, 2006, p. 75).

261 “Assim, entendi com clareza que nunca fui um verdadeiro leitor.” (RILKE, 1979, p. 113).
} 
do rapaz - "Mein Gott, was hast du schlecht gelesen, Malte."262 (cf. RILKE, 1982, p. 160) - e passa a ler ela mesma:

Und dann las sie einen von Bettinens Briefen.

Ich weiß nicht, was ich davon verstand, aber es war, als würde mir feierlich versprochen, dieses alles einmal einzusehen. Und während ihre Stimme zunahm und endlich fast jener glich, die ich vom Gesang her kannte, schämte ich mich, daß ich mir unsere Versöhnung so gering vorgestellt hatte. Denn ich begriff wohl, daß sie das war. Aber nun geschah sie irgendwo ganz im Großen, weit über mir, wo ich nicht hinreichte. ${ }^{263}$ (RILKE, 1982, p. 161).

Malte percebe que há uma identificação entre Abelone e Bettina, mas só a compreende tempos depois: "Das Versprechen erfüllt sich noch immer, irgendwann ist dasselbe Buch unter meine Bücher geraten, unter die paar Bücher, von denen ich mich nicht trenne."264 (RILKE, 1982, p. 161). Malte passa a conhecer o livro de Bettina intimamente, como Abelone o conheceu antes dele ("Nun schlägt es sich auch mir an den Stelle auf, die ich gerade meine [...]." ${ }^{265}$, p. 161), e crê que talvez tenha chegado a compreender a importância dessas cartas para Abelone.

Em comparação com as experiências de leitura narradas anteriormente nessa mesma anotação, podemos afirmar que esse volume de cartas é a primeira leitura com a qual Malte se envolve de fato. Bettina tinha a capacidade de criar imagens tão vívidas que sua figura chega a ser mais nítida para ele do que a de Abelone (cf. RILKE, 1982, p. 162). Quando Malte se pergunta qual seria a razão de esses textos ficarem à sombra dos de seu interlocutor, sua interpretação é de que Goethe não soube corresponder à magnitude do sentimento de Bettina e o obscureceu.

Wie ist es möglich, daß nicht noch alle erzählen von deiner Liebe? [...] Du selber wußtest um deiner Liebe Wert, du sagtest sie laut deinem größesten Dichter vor, daß er sie menschlich mache; denn sie war noch Element. [...] Diese Liebende ward ihm auferlegt, und er hat sie nicht bestanden. Was heißt es, daß er nicht hat erwidern können? Solche Liebe bedarf keiner Erwiderung, sie hat Lockruf und Antwort in sich; sie erhört sich selbst. ${ }^{266}$ (RILKE, 1982, p. 162)

262 “-Meu Deus, Malte, como você leu mal.” (RILKE, 1979, p. 116).

263 "E leu uma das cartas de Betina. Não sei o que entendi, mas era como se me prometessem solenemente que algum dia haveria de entender. E enquanto aquela voz crescia, finalmente quase igual à que eu conhecia das canções, envergonhei-me por ter imaginado nossa reconciliação tão insignificante. Pois percebi que aquilo era a reconciliação. Mas acontecia em algum lugar, grandiosa, muito acima de mim, onde eu não alcançava." (RILKE, 1979, p. 116).

264 "A promessa ainda se cumpre, por acaso o mesmo livro aparece entre os meus, aqueles poucos de que não me separo.” (RILKE, 1979, p. 116).

265 “E quando se abre nos lugares que desejo [...].” (RILKE, 1979, p. 116).

266 “Como é possível que todos não falem no teu amor? [...] Mas sabias do valor desse afeto, e o dizias em alta voz ao teu grande poeta, para que este o tornasse humano; o amor era ainda apenas elemento. [...] fora-lhe 
A falta de resposta ao amor de Bettina não teria sido um problema para ela: o elemento chave que Malte depreende dessas cartas é o ideal do amor intransitivo, um amor que ou não é dirigido a um objeto específico, ou o ultrapassa, e o sentimento basta em si mesmo. Nessa possibilidade de um amor que não necessita de resposta, Malte reconhece uma potência criadora praticamente ilimitada, e a identifica no trabalho de uma série de escritoras e poetas europeias de diferentes épocas ${ }^{267}$.

O fato de todas essas poetas serem mulheres não é uma coincidência. No início da segunda parte do romance, Malte observa, a respeito das jovens que vão aos museus desenhar as obras expostas, que "Sie sind ganz nahe daran, sich aufzugeben und so von sich zu denken, wie Männer etwa von ihnen reden könnten, wenn sie nicht da sind"268 (RILKE, 1982, p. 109, grifo do autor):

Das kommt, glaube ich, weil sie müde sind. Sie haben Jahrhunderte lang die ganze Liebe geleistet, sie haben immer den vollen Dialog gespielt, beide Teile. Denn der Mann hat nur nachgesprochen und schlecht. Und hat ihnen das Erlernen schwer gemacht mit seiner Zerstreutheit, mit seiner Nachlässigkeit, mit seiner Eifersucht, die auch eine Art Nachlässigkeit war. Und sie haben trotzdem ausgeharrt Tag und Nacht und haben zugenommen an Liebe und Elend. Und aus ihnen sind, unter dem Druck endloser Nöte, die gewaltigen Liebenden hervorgegangen, die, während sie ihn riefen, den Mann überstanden [...]."269 (RILKE, 1982, p. 109).

Por esse ponto de vista, a negligência imposta às mulheres constituiu um aprendizado - árduo, certamente. Mas, pelo fato de ele não decorrer de um sofrimento isolado, e sim comum a muitas mulheres, ao longo do tempo esse aprendizado foi ganhando um caráter coletivo, e talvez essa fosse a chave de sua força. Não foi uma única mulher que aprendeu, sozinha, a oferecer um amor equivalente ao de duas pessoas - para o outro e para si mesma, uma vez que

oferecida uma tal amante, e ele não venceu a prova. Que significa não ter sido capaz de corresponder? Um amor assim não tem necessidade de resposta, pois contém apelo e resposta; escuta-se a si próprio.” (RILKE, 1979, p. 117).

267 São elas: além de Bettina von Arnim (1785-1859), Heloïse (1101-1164), Mariana Alcoforado (1640-1723), Sappho (nascida por volta de 612 a.C.), Gaspara Stampa (1523-1554), Béatrice Gräfin von Die (século XII), Clara d'Anduze (século XIII), Louise Labé (1525-1566), Marceline Desbordes-Valmore (1786-1859), Élisa Mercoeur (1809-1835), Charlotte Haydée (1694-1733) e Julie de Lespinasse (1732-1776) (cf. STAHL, 1996, p. 999; 1028-1029).

268 "Estão muito próximas de desistirem de si, e de pensarem em si mesmas assim como os homens poderiam falar delas quando não estão presentes.” (RILKE, 1979, p. 78).

269 “Acho que isso acontece porque estão cansadas. Por séculos a fio foram elas que cumpriram todo o amor, sempre recitaram as duas partes do diálogo. Pois o homem apenas repetia, e mal. E lhes tornava difícil a aprendizagem, com sua distração, com sua negligência, com seu ciúme que também era uma espécie de negligência. E apesar disso elas aguentaram dia e noite, crescendo em amor e sofrimento. E dentre elas, sob a pressão de intermináveis dores, emergiram as poderosas amantes que, enquanto o chamavam, superavam seu homem [...]." (RILKE, 1979, p. 78). 
esse outro é negligente. Trata-se antes de um conhecimento compartilhado e transmitido entre mulheres de geração a geração - adquirido ao longo de séculos de experiência com a negligência do outro. Pode-se afirmar que é esse conhecimento que Malte acessa através das cartas de Bettina von Arnim e de Marianna Alcoforado, da poesia de Safo e das demais escritoras mencionadas. E como Malte, por ser homem, não faz parte dessa cadeia de transmissão de conhecimento, a ele só é possível acessá-lo através da leitura.

Ler é, assim, também uma forma de aprender a ver - a ver o outro, detentor de outra experiência e de outra sabedoria, objetivamente. De suas primeiras experiências de leitura, Malte diz que:

Mit jeder Zeile brach man die Welt an. Von den Büchern war sie heil und vielleicht wieder ganz dahinter. Wie aber sollte ich, der nicht lesen konnte, es mit allen aufnehmen? Da standen sie, selbst in diesem bescheidenen Bücherzimmer, in so aussichtsloser Überzahl und hielten zusammen. Ich stürzte mich trotzig und verzweifelt von Buch zu Buch und schlug mich durch die Seiten durch wie einer, der etwas Unverhältnismäßiges zu leisten hat. ${ }^{270}$ (RILKE, 1982, p. 158-159).

É digno de nota que todos os autores que Malte menciona ter lido na época são homens ${ }^{271}$. A miríade de assuntos trazidos em seus livros parece quase esmagar o jovem e inexperiente leitor. É somente com as cartas de Bettina von Arnim que Malte aprende a ler. A diferença entre essas experiências de leitura talvez possa entendida através da distinção, vista anteriormente, que Rilke faz nas cartas sobre Cézanne, entre julgar e dizer, entre dizer "eu amo isto" e dizer "isto é" (cf. RILKE, 1996, p. 616). Se o amor intransitivo não é voltado para um objeto específico ou basta em si mesmo, esse ideal está próximo do entendimento que Rilke depreende da obra de Cézanne: de que é preciso, primeiro, conseguir dedicar o amor a todas as coisas que podem ser representadas, sem distinção e, depois, consumir esse amor no processo de representar essas mesmas coisas, usá-lo como combustível do trabalho, e não como protagonista da obra.

Hinter dieser Hingabe beginnt, mit Kleinem zunächst, die Heiligkeit: das einfache Leben einer Liebe, die bestanden hat, die ohne sich dessen je zu rühmen, zu allem tritt, unbegleitet, unauffällig, wortlos. Die eigentliche Arbeit, die Fülle der

\footnotetext{
270 "A cada frase começamos o mundo. Antes dos livros ele fora algo intacto, e talvez depois deles voltasse a ficar inteiro. Mas como poderia eu, que nem sabia ler, dar conta de todos? Estavam ali, mesmo naquela modesta biblioteca pareciam em número desesperançadamente enorme, e todos unidos. Desafiante e desesperado atireime de livro em livro, abrindo caminho pelas páginas, como quem tem diante de si uma tarefa desmesurada." (RILKE, 1979, p. 114).

271 Os nomes mencionados são: Friedrich Schiller (1759-1805), Jens Baggesen (1764-1826), Adam Öhlenschläger (1779-1850), Adolph Schack-Staffeldt (1769-1826), Sir Walter Scott (1771-1832) e Calderón de la Barca (1600-1681) (cf. STAHL, 1996, p. 994).
} 
Aufgaben, alles fängt erst hinter diesem Bestehen an [... $]^{272}$ (RILKE, 1996, p. 624$625)$.

272 "Por trás de tal entrega tem início a santidade, a princípio nas pequenas coisas: a vida simples de um amor que se impôs sem fazer alarde, que se encaminha para tudo, desacompanhado, discreto, sem palavras. O trabalho próprio, a plenitude das tarefas, tudo só começa por trás desta imposição [...].” (RILKE, 2006, p. 76). 


\title{
Considerações finais
}

Para Malte Laurids Brigge, o jovem poeta dinamarquês criado por Rilke para protagonizar as Aufzeichnungen, a experiência parisiense traz uma intensa transformação, promovida pelo novo aprendizado do olhar. Na quarta anotação do livro, que é também a primeira anotação programática em que o personagem Malte afirma que está aprendendo a ver, ele anuncia pela primeira vez esse processo de mudança interna:

\begin{abstract}
Ich habe heute einen Brief geschrieben, dabei ist es mir aufgefallen, daß ich erst drei Wochen hier bin. Drei Wochen anderswo, auf dem Lande zum Beispiel, das konnte sein wie ein Tag, hier sind es Jahre. Ich will auch keinen Brief mehr schreiben. Wozu soll ich jemandem sagen, daß ich mich verändere? Wenn ich mich verändere, bleibe ich ja doch nicht der, der ich war, und bin ich etwas anderes als bisher, so ist klar, daß ich keine Bekannten habe. Und an fremde Leute, an Leute, die mich nicht kennen, kann ich unmöglich schreiben. ${ }^{273}$ (RILKE, 1982, p. 10-11).
\end{abstract}

Essa passagem confirma a suspeita de que Malte não é parisiense e está há pouco tempo na cidade (na primeira anotação, ele narra uma caminhada em que utiliza um mapa) e que o contexto da metrópole é inteiramente novo para ele. Uma vez que em nenhuma passagem do romance Malte se refere ao aprendizado do olhar como tendo sido transmitido por uma pessoa - um mestre, por exemplo - o leitor é levado a presumir que é a nova experiência de viver em uma cidade grande que o leva a aprender a ver. E ainda: ela acelera o processo de transformação em Malte a partir desse novo olhar. Essa mudança não é encarada pelo protagonista como algo frágil ou efêmero: ao contrário, ela é determinante para que ele refute suas relações anteriormente estabelecidas.

No entanto, páginas adiante, a anotação 22 recebe a marcação de "Ein Briefentwurf", embora em nenhum momento o possível destinatário da carta seja indicado. Nela, Malte escreve:

Ich bin in Paris, die es hören freuen sich, die meisten beneiden mich. Sie haben recht. Es ist eine große Stadt, groß, voll merkwürdiger Versuchungen. Was mich betrifft, ich muß zugeben, daß ich ihnen in gewisser Beziehung erlegen bin. Ich glaube, es läßt sich nicht anders sagen. Ich bin diesen Versuchungen erlegen, und das hat gewisse Veränderungen zur Folge gehabt, wenn nicht in meinem Charakter, so doch in meiner Weltanschauung, jedenfalls in meinem Leben. Eine vollkommen

273 "Hoje escrevi uma carta e ocorreu-me que faz apenas três semanas que estou aqui. Três semanas em outro lugar - por exemplo, no campo - poderiam ser como um dia; aqui são anos. Também não quero mais escrever cartas. Para que diria a outra pessoa que estou me modificando? Se me modifico, já não sou aquele que fui, sou algo diferente do que até agora era, então é evidente que não tenho conhecidos. E é impossível escrever cartas para gente desconhecida, gente que não me conhece.” (RILKE, 1979, p. 6). 
andere Auffassung aller Dinge hat sich unter diesen Einflüssen in mir herausgebildet, und es sind gewisse Unterschiede da, die mich von den Menschen mehr als alles Bisherige abtrennen. Eine veränderte Welt. Ein neues Leben voll neuer Bedeutungen. Ich habe es augenblicklich etwas schwer, weil alles zu neu ist. Ich bin ein Anfänger in meinen eigenen Verhältnissen. ${ }^{274}$ (RILKE, 1982, p. 62).

Essa passagem ilustra o argumento de que a novidade da metrópole desencadeia em Malte uma mudança de percepção: o que o separa das outras pessoas é o novo paradigma do olhar, que ele ainda está a aprender. Na sequência, Malte escreve uma reflexão sobre o poema "Une charogne", de Baudelaire, dizendo que "Es kann sein, daß ich es jetzt verstehe."275 (RILKE, 1982, p. 62). Malte não reconhece apenas que a vivência na cidade grande teve para ele a consequência de uma nova maneira de olhar para o mundo; ele reconhece que o novo contexto em que vive modifica também os modos de narrar, o que tem impacto direto em seu ofício de escritor. E, nesse sentido, o novo paradigma do olhar oferece a Malte o vislumbre de um novo paradigma de escrita. Quando seu pai morre, algo dentro de Malte lhe confirma que o tempo de sua família ficou para trás: “[...] 'Heute Brigge und nimmermehr', sagte etwas in mir."276 (RILKE, 1982, p. 128); ele pensa na perfuração do coração do pai, mas, "An mein Herz dachte ich nicht. [...] Es war ein einzelnes Herz. Es war schon dabei, von Anfang anzufangen."277 (RILKE, 1982, p. 128). Sem mais nenhum vínculo com o passado, o recomeço de Malte está no aprendizado do olhar, que significa para ele aprender novamente a escrever - ou, antes, aprender a escrever na Modernidade.

Como vimos no segundo capítulo desta pesquisa, a experiência parisiense foi transformadora para Rilke, em grande medida por causa de seu encontro com as obras de Rodin e de Cézanne. Rilke não deixou de registrar e ressaltar a contribuição de Rodin para seu próprio trabalho: 'Et c'est la grande renaissance de ma vie et de mon espoir que vous m'avez

\footnotetext{
274 "Estou em Paris, quem ouve isso alegra-se, a maioria me inveja. Têm razão. É uma grande cidade, grande e repleta de singulares tentações. Quanto a mim, devo admitir que de certa forma entreguei-me a elas. Acho que não há outro modo de dizer isso. Cedi a essas tentações, e isso trouxe certas transformações, se não no meu caráter, na minha concepção do mundo, e certamente na minha vida. Sob essas influências, formou-se em mim um conceito totalmente diverso de todas as coisas, há certas distinções que me separam mais das pessoas do que tudo até hoje. Um mundo transformado. Uma nova vida cheia de novos significados. No momento é um pouco difícil para mim, porque tudo é novo demais. Sou um aprendiz das minhas próprias circunstâncias de vida." (RILKE, 1979, p. 44).

275 “Talvez agora eu o entenda.” (RILKE, 1979, p. 44).

276 ““Hoje Brigge e nunca mais Brigge’, disse algo em mim.” (RILKE, 1979, p. 92).

277 “Não pensei no meu coração. [...] Era apenas um coração individual. E estava começando do início.” (RILKE, 1979, p. 92).
} 
donné. C'était hier dans le silence de votre jardin que je me suis trouvé moi-même."278 (RILKE, 1929, p. 41-42). As mudanças promovidas pelos aprendizados que o poeta recebeu dos artistas foram anunciadas também nos títulos de seus livros de poemas escritos nos anos seguintes, Neue Gedichte e Der Neuen Gedichte anderer Teil: não se tratavam apenas de uma nova produção do escritor, mas antes, de poemas compostos de acordo com um novo paradigma de escrita, desenvolvido a partir da experiência parisiense e seus aprendizados com as artes visuais. O principal desses aprendizados é o do olhar objetivo, da Sachlichkeit. Ao contrário de seu personagem Malte, porém, a mudança em Rilke é menos abrupta e dramática: ela é parte de um longo processo de estudo e reflexão sobre arte, que culmina com o encontro com Rodin. Seu aprendizado do olhar não é suscitado pela vivência na cidade grande, embora Paris tenha lhe causado um choque tão grande quanto o choque em Malte descrito nas Aufzeichnungen. A reflexão sobre o olhar esteve presente em sua poesia e em seus escritos sobre arte anteriores à sua primeira viagem a Paris, em 28 de agosto de 1902, como atestam o texto "Von der Landschaft", discutido aqui no segundo capítulo, e o poema que abre a primeira parte de seu livro Das Stundenbuch, de 1899:

\footnotetext{
Da neigt sich die Stunde und rührt mich an mit klarem, metallenem Schlag: mir zittern die Sinne. Ich fühle: ich kann und ich fasse den plastischen Tag.

Nichts war noch vollendet, eh ich es erschaut, ein jedes Werden stand still.

Meine Blicke sind reif, und wie eine Braut kommt jedem das Ding, das er will.

Nichts ist mir zu klein und ich lieb es trotzdem und mal es auf Goldgrund und groß, und halte es hoch, und ich weiß nicht wem löst es die Seele los...279 (RILKE, 2007, p. 11).
}

$\mathrm{Na}$ interpretação de Strathausen, o poema narra o momento de inspiração criativa como uma experiência sensorial, sinestésica, na qual todos os sentidos são mobilizados (cf. STRATHAUSEN, 2003, p. 191). Mas é notável que, de todos os sentidos, o olhar é destacado: o olhar do poeta está "maduro", pronto para receber o que quiser, como uma noiva.

\footnotetext{
278 "E esse é o grande renascimento de minha vida e de meu espírito que você me deu. Foi aqui, no silêncio do seu jardim, que encontrei a mim mesmo." (Tradução nossa).

279 "A hora inclina-se e toca em $\mathrm{mim} / \mathrm{com}$ claro bater metálico./ Os sentidos me tremem. Sinto: eu posso.../ E colho o dia plástico.// Nada estava acabado antes de eu ver:/ todo o devir aguardando em quietude./ Maduros meus olhares: a cada um,/ como uma noiva, chega a coisa ansiada.// Nada é pequeno para mim: gosto de tudo/ e tudo eu pinto sobre ouro com grandeza/ e bem alto o levanto - sem saber de quem/ vai a alma libertar." (RILKE, 1993, p. 15).
} 
E, de todas as coisas que o olho pode receber, nenhuma é desimportante. Além disso, seu olhar é determinante para completar a existência das coisas ("Nichts war noch vollendet, eh ich es schaut,/ ein jedes Werden stand still.”). Para Strathausen, a união entre o poeta e as coisas, que ocorre através do olhar, marca uma quebra da dicotomia entre sujeito e objeto: "The poet stands not opposed to the world he perceives, but is part of it, engaged in an eternal process of receiving and giving that sustains all things." 280 (STRATHAUSEN, 2003, p. 191). Essa concepção do ato de olhar para o mundo como algo que ocorre de dentro para fora vai ao encontro do entendimento que Rilke tem do trabalho do olhar nas pinturas de Cézanne, como vimos anteriormente. Também Malte, nas Aufzeichnungen, descobre que não há separação entre sujeito e objeto à medida que aprender a ver, assim como descobre a sua própria interioridade.

Entretanto, na carta que escreve a Clara em 13 de outubro de 1907, parte da compilação Briefe über Cézanne, Rilke contesta seu próprio trabalho no Stundenbuch, afirmando que, quando o escreveu, não via o mundo propriamente dito, mas apenas o que o mundo o inspirava (cf. RILKE, 1996, p. 615-616). Em outras palavras, pode-se dizer que Rilke reconhece que, embora tenha escrito sobre o papel do olhar na criação poética em 1899, naquele momento ele ainda não sabia ver, no sentido da objetividade que ele atribui mais tarde a essa formulação. É possível ainda apontar no poema inicial do Stundenbuch, alguns aspectos que se modificam na poética de Rilke após seu encontro com Rodin e com as pinturas de Cézanne, em 1902 e 1907 respectivamente, ou seja, poucos anos depois de tê-lo escrito. A primeira é relacionada à ideia de inspiração: um dos ensinamentos de Rodin mais ressaltados por Rilke é o do trabalho constante, e na carta de 11 de setembro de 1902 enviada ao escultor, o poeta afirma que sua escrita estivera, até aquele momento, ligada aos raros momentos de inspiração, o que o levava a uma inconstância criativa - ou, como Rilke coloca, “C'était une vie pleine d'abîmes." ${ }^{281}$ (RILKE, 1929, p. 41). Rodin o havia ensinado que o trabalho criativo não deveria depender da inspiração, mas que a criação artística depende de uma vida dedicada ao trabalho, e o poeta acata essa ideia prontamente: "Je sens que travailler c'est vivre sans mourir."282 (RILKE, 1929, p. 41).

\footnotetext{
280 "O poeta não se coloca oposto ao mundo que ele percebe, mas é parte dele, envolvido em um eterno processo de dar e receber que sustenta todas as coisas." (Tradução nossa).

281 "Era uma vida cheia de abismos." (Tradução nossa).

282 "Sinto que trabalhar é viver sem morrer.” (Tradução nossa).
} 
A segunda está relacionada à expressividade do amor no poema: "Nichts ist mir zu klein und ich lieb es trotzdem [...]." ${ }^{283}$ (RILKE, 2007, p. 11). Em 1907, ainda na carta de 13 de outubro, Rilke afirma, a partir de Cézanne, que é preciso ir além do amor: “[...] es ist ja natürlich, daß man jedes dieser Dinge liebt, wenn man es macht: zeigt man das aber, so macht man es weniger gut; man beurteilt es, statt es zu sagen." ${ }^{284}$ (RILKE, 1996, p. 616, grifos do autor). Segundo Rilke, o equívoco estaria em dizer que se ama a determinada coisa que se quer retratar: dessa forma, o que se expressa no poema (ou na pintura, que é o exemplo dado por ele) é o sentimento do autor, e não a coisa em si.

Para representar o objeto - a coisa em si - seria preciso primeiro olhar para ele objetivamente, e não deixar a percepção ser afetada pelo sentimento. O sentimento do artista deveria, por esse viés, ser mantido fora da obra e ser consumido no processo de trabalho, sendo que a maior parte do trabalho é aprender a olhar de forma objetiva. Esses pressupostos, da escrita como fruto do trabalho constante e do amor investido no processo de trabalho fazem parte das elaborações de Malte a partir do aprendizado do olhar objetivo, que é o cerne do seu projeto estético. Ele deve escrever dia e noite (“Tag und Nacht”) (cf. RILKE, 1982, p. 25), e encontra, na leitura de Safo, Bettina von Arnim e Mariana Alcoforado, entre outras escritoras, exemplos de como o amor intransitivo pode ser uma potência criadora, ou seja: consumir o amor no trabalho poético significa aqui criar a partir de um amor que não se concentra em um objeto definido e prescinde de uma resposta. Mas o que temos nas Aufzeichnungen é o processo de elaboração dessas premissas estéticas a partir do aprendizado do olhar, que ocorre na escrita nas anotações, dando ao livro um caráter de estudo e reflexão, de algo que está ainda em construção. É nesse sentido que Gutjahr afirma que a narrativa das Aufzeichnungen tem um caráter de oficina (“Werkstattcharakter") e está em statu nascendi, “[...] da es nicht um das Erzählen von etwas geht, sondern um das Erzählen selbst, das erst im Prozeß des Aufzeichnens Gestalt annehmen kann."285 (GUTJAHR, 1993, p. 376, grifo da autora). É também por esse motivo que Blanchot elenca o romance das Aufzeichnungen como um exemplo do que "[...] poderia ser o diário da experiência criativa [...]." (BLANCHOT, 2005, p. 277). A escrita de Malte marca o início de uma transformação que não se completa no livro, e talvez por isso alguns críticos (como Blanchot e Lavagetto) e o próprio Rilke (por

\footnotetext{
283 "Nada é pequeno para mim: gosto de tudo [...]." (RILKE, 1993, p. 15).

284 “[...] é mesmo natural que amemos cada uma destas coisas; mas se mostramos isso, amamos menos; julgamos, em vez de dizer." (RILKE, 2006, p. 62).

285 “....] pois ela não se passa como a narrativa sobre algo, mas sim sobre a própria narrativa, que se pode presumir no processo da forma da anotação.” (Tradução nossa).
} 
exemplo, na carta a Clara de 17 de outubro de 1907) tenham concluído que Malte fracassa em sua tarefa.

Rilke, como seu personagem, toma o aprendizado do olhar e seus desdobramentos como premissas para a escrita poética, mas, diferentemente de Malte, as leva adiante em seus Neue Gedichte. Seu ponto de partida está nas artes visuais: Strathausen afirma que Rilke combina as palavras no poema como Cézanne combina as cores na tela ou como Rodin combina diferentes superfícies na escultura (cf. STRATHAUSEN, 2003, p. 199). De acordo com o estudioso, a busca do poeta em estabelecer uma relação mais imediata com o mundo através do trabalho do olhar objetivo só pode ser legitimada se ele conseguir apresentar, no poema, uma coisa em si (cf. STRATHAUSEN, 2003, p. 198), de modo semelhante a como Rodin cria a ilusão de um corpo natural na escultura e Cézanne, a ilusão da materialidade das coisas representadas. Para chegar a esse resultado, Rilke combina o retrato do exterior do objeto e a capacidade de autorreferencialidade da linguagem para criar uma tensão entre espaço interno e externo, entre a simultaneidade do mundo e da palavra, entre a coexistência de materialidade e significado (cf. STRATHAUSEN, 2003, p. 200-202). Strathausen argumenta ainda que o trabalho do olhar objetivo no poema não marca uma transformação estética, mas sim uma abertura que força o olhar do leitor a oscilar - sem descanso - entre interior e exterior, entre ler o poema e ver a coisa representada (cf. STRATHAUSEN, 2003, p. 202). Do mesmo modo como a ilusão de movimento da escultura de Rodin só se produz através do olhar do espectador, a metamorfose da palavra em coisa, no poema de Rilke, também só se produz através da leitura.

A poesia de Rilke baseada no ideal da Sachlichkeit tem em Adorno um de seus principais críticos. Segundo Strathausen, Adorno critica o abandono da subjetividade, a recusa de Rilke em especificar a função da arte e, principalmente, a separação que Rilke estabelece entre arte e reflexão crítica (cf. STRATHAUSEN, 2003, p. 203). Além disso, Adorno argumenta que, por causa de seu "culto à coisa" ("Dingkult"), Rilke antropomorfiza os objetos, e isso seria uma fraqueza estética de seus poemas (cf. STRATHAUSEN, 2003, p. 205). Strathausen aponta também que a ambiguidade produzida pela tensão entre interior e exterior nos Dinggedichte de Rilke se aproxima da crítica que Adorno faz a obras de arte que imitam o que não podem vir a ser, admitindo sua própria impossibilidade (cf. STRATHAUSEN, 2003, p. 204). É o que ocorreria com os Neue Gedichte: "They, too, acknowledge their 'own impossibility' and thus undermine the aesthetic ideal of 'sachliches 
Sagen' that informs them." 286 (STRATHAUSEN, 2003, p. 204). Essa observação levanta a questão do sucesso ou fracasso de Rilke em buscar a materialização da coisa na linguagem poética - e Strathausen, por exemplo, desenvolve seu argumento tomando como pontos de partida as artes visuais e a fenomenologia de Husserl com o objetivo de defender os Neue Gedichte.

Há ainda outro aspecto do projeto estético de Rilke que está relacionado às artes visuais e é problematizado nas Aufzeichnungen, mas que atua principalmente na organização do poeta para trabalhar: o ethos do artista solitário. Como vimos no segundo capítulo, antes de sua experiência parisiense Rilke já defendia que o artista é o solitário por excelência, e o encontro com Rodin e com Cézanne reforça essa crença. A insistência na solidão está também ligada à separação entre criação e reflexão crítica. Rilke defende em diversos momentos que a crítica é prejudicial ao desenvolvimento da criação artística, pois ela interfere no processo do artista, dificultando o abandono de conceitos pré-estabelecidos para desempenhar o olhar objetivo. Tanto Rodin como Cézanne se tornam exemplos de artistas que trabalharam por anos de forma isolada e atingiram, na visão de Rilke, o ideal da Sachlichkeit. Todorov afirma que Rilke adota o ideal da dedicação total ao trabalho artístico de Rodin e busca a solidão propícia para criar. No entanto, segundo o estudioso,

\begin{abstract}
Alguns meses de experiência bastam a Rilke para lhe mostrar que esse projeto - ao qual, porém, ele nunca renuncia - é claudicante: persegui-lo não lhe traz satisfação, nem mesmo um apaziguamento. Dir-se-ia, ao contrário, que o conduz progressivamente a um estado depressivo do qual só consegue se livrar no decorrer de breves momentos de exaltação amorosa ou de raros períodos de produção intensa. Esse estado se manterá até sua morte, em 1926. O que ele experimenta ao longo desses 25 anos é, em particular, uma grande fadiga, um endurecimento, um torpor que paralisa a vontade, uma "perpétua distração interior", um esgotamento que o conduz à impotência e que se acompanha por angústias sufocantes, semelhantes às vividas quando era criança. Essa fraqueza constante o conduz, muito antes que sua doença fatal se apresente, a frequentar sanatórios e casas de repouso. (TODOROV, 2011, p. 100-101).
\end{abstract}

Todorov examina, em seu ensaio, os efeitos que a solidão e a frustração relacionada ao trabalho têm na vida de Rilke, e apenas por essa breve passagem, seria possível elucubrar que também por esse ângulo o projeto estético de Rilke teria fracassado. Nesta pesquisa, no entanto, nosso objetivo não foi examinar se Malte e Rilke sucedem ou fracassam em concretizar o projeto estético decorrente do aprendizado do olhar. Mas sim, procuramos investigar o aspecto programático do romance Die Aufzeichnungen des Malte Laurids Brigge e estabelecer relações entre o projeto estético que o protagonista Malte desdobra

286 "Eles também reconhecem sua 'própria impossibilidade' e assim minam o ideal estético do 'dizer objetivo' que os informa." (Tradução nossa). 
gradativamente nas anotações e a reflexão sobre a criação artística que Rilke desenvolve na mesma época em que inicia a escrita do romance, e que marca uma mudança significativa em sua escrita poética. É preciso ressaltar ainda que toda a obra de Rilke - incluindo o romance das Aufzeichnungen, os livros de poemas e os escritos estéticos - embora seja extensamente estudada em diversas partes do mundo, devido à sua complexidade e riqueza, oferece uma fonte inesgotável de pesquisa e análise, sendo que o viés apresentado nesta dissertação é apenas uma entre inúmeras possibilidades, e, ainda assim estamos longe de tê-la esgotado. 


\section{Referências bibliográficas}

AGAMBEN, Giorgio. "Infância e história. Ensaio sobre a destruição da experiência." In: Infância e história. Destruição da experiência e origem da história. Tradução de Henrique Burigo. Belo Horizonte: Editora UFMG, 2014. P. 19-78.

ALMEIDA, Guilherme de. As flores das Flores do mal de Baudelaire. São Paulo: 34, 2010.

ANDREAS-SALOMÉ, Lou; RILKE, Rainer Maria. Briefwechsel. Herausgegeben von Ernst Pfeiffer. Frankfurt am Main: Insel, 1989.

ARGAN, Giulio Carlo. Arte Moderna. Tradução de Denise Bottmann e Federico Carotti. São Paulo: Cia. Das Letras, 2010.

BAUDELAIRE, Charles. Les fleurs du mal. Paris: Librairie Générale Française, 1972.

Pequenos poemas em prosa. Edição bilíngue. Tradução de Dorothée de Bruchard. São Paulo: Hedra, 2009.

O pintor da vida moderna. Tradução de Tomaz Tadeu. Belo Horizonte: Autêntica, 2010.

BENJAMIN, Walter. Charles Baudelaire, um lírico no auge do capitalismo. Tradução de José Carlos M. Barbosa e Hemerson A. Baptista. São Paulo: Brasiliense, 2011.

. "O narrador". In: Magia e técnica, arte e política. Tradução de Sergio Paulo Rouanet. São Paulo: Brasiliente, 2008. P. 197-221.

Passagens. Tradução de Irene Aron e Cleonice Mourão. Belo Horizonte; São Paulo: UFMG; Imprensa Oficial, 2009.

BLANCHOT, Maurice. "Rilke e a exigência da morte". In: O espaço literário. Tradução de Álvaro Cabral. Rio de Janeiro: Rocco, 2011. P. 126-174.

. "O diário íntimo e a narrativa”. In: O livro por vir. Tradução de Leyla PerroneMoisés. São Paulo: Martins Fontes, 2005. P. 270-278.

BOEHM, Gottfried (org.). Rilke und die bildende Kunst. Frankfurt am Main: Insel, 1985.

BRIDGE, Helen. "Rilke and the Modern Portrait". In: The Modern Language Review, Vol. 99, No. 3. Cambridge: Modern Humanities Research Association, 2004. P. 681-695.

BROEK, Claire Y. van den. "How the Panther Stole the Poem: The Search for Alterity in Rilke's 'Dinggedichte"'. In: Monatshefte, Vol. 105, No. 2. Madison: University of Wisconsin Press, 2013. P. 225-246.

BRUNO, Paul W. Kant's concept of genius: it's origin and function in the third critique. London; New York: Continuum, 2010. 
BÜSSGEN, Antje. "Bildende Kunst". In: ENGEL, Manfred (org.). Rilke Handbuch. Stuttgart: J. B. Metzler: 2013. P. 130-150.

CAMPOS, Augusto de. Coisas e Anjos de Rilke. São Paulo: Perspectiva, 2015.

Rilke: Poesia-Coisa. Rio de Janeiro: Imago, 1994.

CHIPP, Herschel B. "Paul Cézanne. Excertos de cartas". In: Teorias da arte moderna. São Paulo: Martins Fontes, 1999. P. 13-20.

COSTA, Alexandre Rodrigues da. A transfiguração do olhar: um estudo das relações entre literatura e artes plásticas em Rainer Maria Rilke e Clarice Lispector. Tese (Doutorado). Faculdade de Letras, Universidade Federal de Minas Gerais, Belo Horizonte, 2005.

COSTA, Mércia Elena de Souza. Weltinnenraum e a teoria da relevância: a semelhança interpretativa na tradução dos Cadernos de Malte Laurids Brigge. Dissertação (Mestrado). Faculdade de Letras, Universidade Federal de Minas Gerais, Belo Horizonte, 2000.

CROWHURST. G. W. "Time and Memory in Rilke's 'Die Aufzeichnungen des Malte Laurids Brigge'”. In: Theoria. A Journal of Social and Political Theory, No. 41. New York: Bergahn Books, 1973. P. 63-78.

DUDEN Deutsches Universalwörterbuch. Mannheim: Dudenverlag, 2007.

DÜRR, Volker. "Personal Identity and the Idea of the Novel: Hegel in Rilke". In: Comparative Literature, Vol. 39, No. 2. Durham: Duke University Press, 1987. P. 97-114.

"Ut sculptura, poiesis. Rilke and Rodin. The surface as structural principle in Malte Laurids Brigge a matter of "translation'”. In: MAHLENDORF, Ursula e RICKELS, Laurence (Org.). Poetry Poetics Translation. Würzburg: Königshausen \& Neumann, 1994. P. 89-95.

EMDE, Ursula. Rilke und Rodin. Marburg: Kunstwiss. Seminar, 1949.

ENGEL, Manfred. "Rilke als Autor der literarischen Moderne". In: Rilke Handbuch. Stuttgart: J. B. Metzler: 2013. P. 507-528.

(org.). Rilke Handbuch. Stuttgart: J. B. Metzler: 2013.

ENGELHARDT, Hartmut (org.). Materialen zu Rainer Maria Rilke "Die Aufzeichnungen des Malte Laurids Brigge". Frankfurt am Main: Suhrkamp, 1974.

FRIEDRICH, Hugo. Estrutura da lírica moderna - da metade do século XIX a meados do século XX. Tradução de Marise M. Curione. São Paulo: Duas Cidades, 1991. 
FUERST, Norbert. "Three German Novels of Education III: R. M. Rilke's 'Malte Laurids Brigge'”. In: Monatshefte, Vol. 38. Madison: University of Wisconsin Press, 1946. P. 463-478.

FÜLLEBORN, Ulrich. "Form und Sinn der 'Aufzeichnungen des Malte Laurids Brigge'. Rilkes Prosabuch und der moderne Roman”. In: Besitz und Sprache. München: Fink, 2000. P. 322-344.

. "Prosalyrik und Roman. Werther - Hyperion - Malte Laurids Brigge". In: Besitz und Sprache. München: Fink, 2000. P. 66-84.

GAGNEBIN. Jeanne Marie. "Memória, história, testemunho". In: Lembrar escrever esquecer. São Paulo: Editora 34, 2014. P. 49-57.

GARBER, Frederick. "Time and the City in Rilke's Malte Laurids Brigge". In: Contemporary Literature, Vol. 11, No. 3. Madison: University of Wisconsin Press, 1970. P. 324-339.

GRIMM, Jacob; GRIMM, Wilhelm. Deutsches Wörterbuch. München: Deutscher Taschenbuch, 1984.

GUTJAHR, Ortrud. "Erschriebene Moderne. Rainer Maria Rilkes Die Aufzeichnungen des Malte Laurids Brigge". In: PIECHOTTA, H. J. e WUTHENOW, R. R. (org.). Die literarische Moderne in Europa, Vol. 2. Opladen: Westdeutscher Verlag, 1993. P. 370-397.

HOFFMANN, E.T.A. A janela de esquina do meu primo. Tradução de Maria Aparecida Barbosa. São Paulo: Cosac Naify, 2010.

HOFFMANN, Torsten. "Rilke als Redner. Publikumskommunikation und Kunstvermittlung in den Vorträgen 'Moderne Lyrik' (1898) und 'Vom Werke Auguste Rodins' (1905/1907)”. In: Zeitschrift für Germanistik, Neue Folge, Vol. 20, No. 3. Berlin: Peter Lang, 2010. P. 543-562.

HÖHLER, Gertrud. Niemandes Sohn. Zur Poetologie Rainer Maria Rilkes. München: Wilhelm Fink, 1979

HUYSSEN, Andreas. "Paris/Childhood: The Fragmented Body in Rilke's Notebooks of Malte Laurids Brigge". In: HUYSSEN, A. e BATHRICH, D. (org.). Modernity and the Text: Revisions of German Modernism. NY: Columbia University Press, 1989. P. 113-141.

JAFFE, Kineret S. "The Concept of Genius: Its Changing Role in Eighteenth-Century French Aesthetics". In: Journal of the History of Ideas, Vol. 41, No. 4. Philadelphia: University of Pennsylvania Press, 1980. P. 579-599. 
KANGUSSU, Imaculada. "Sobre a alteridade do artista em relação ao mundo que o cerca, segundo Herbert Marcuse”. In: Kriterion, Vol. 46, No. 112. Belo Horizonte: UFMG, 2005. P. 345-356.

KANT, Roswitha M. Visualität in Rainer Maria Rilkes Die Aufzeichnungen des Malte Laurids Brigge: Eine Untersuchung zum psychoanalytischen Symbolbegriff. Frankfurt am Main: Peter Lang, 2002.

KLIENEBERGER, H. R. "Romanticism and Modernism in Rilke's 'Die Aufzeichnungen des Malte Laurids Brigge"”. In: The Modern Language Review, Vol. 74. Cambridge: Modern Humanities Research Associations, 1979. P. 361-367.

KOCH, Manfred. "Pantomimen der Großstadt. Rilkes Umschrift von Rodins Baudelaire". In: Weimarer Beiträge: Zeitschrift für Literaturwissenschaft, Ästhetik und Kulturwisenschaften, Vol. 63. Wien: Passagen, 2017. P. 211-222.

"Schriften zu Kunst und Literatur". In: ENGEL, Manfred (org.). Rilke Handbuch. Stuttgart: J. B. Metzler: 2013. P. 480-497.

$\mathrm{KOCH}$, Reinhard. "Bild und Text in Rilkes 'Aufzeichnungen des Malte Laurids Brigge"”. In: Colloquia Germanica, Vol. 26. Tübigen: Narr/Francke/Attempto, 1993.

KOPP, Michaela. Rilke und Rodin. Auf der Suche nach der wahren Art des Schreibens. Frankfurt am Main: Peter Lang, 1999.

KRIESSBACH, Martina. Rilke und Rodin: Wege einer Erfahrung des Plastischen. Frankfurt am Main: Peter Lang, 1984.

KRINGS, Marcel. “Ästhetische Inkarnation. Zur formalen Struktur von Rilkes 'Malte Laurids Brigge"”. In: Deutsch Vierteljahrsschrift für Literaturwissenschaft und Geistesgeschichte, Vol. 77. Stuttgart: Metzler, 2003.

KRUSE, Bernhard A. Auf dem extremen Pol der Subjektivität: zu Rilkes "Aufzeichnungen des Malte Laurids Brigge". Wiesbaden: DUV, 1994.

KURZ, Martina. Bild-Verdichtungen: Cézannes Réalisation als poetisches Prinzip bei Rilke und Handke. Göttingen: Vandenhoeck \& Ruprecht, 2003.

LAUTERBACH, Dorothea. "Die Aufzeichnungen des Malte Laurids Brigge". In: ENGEL, Manfred (org.). Rilke Handbuch. Stuttgart: J. B. Metzler: 2013. P. 318-336.

LAVAGETTO, Andreina. "Os cadernos de Malte Laurids Brigge". In: MORETTI, Franco (org.). A cultura do romance. São Paulo: Cosac Naify, 2009. P. 951-960.

LINDEN, Patricia. "*Im Manuskript an den Rand geschrieben": Spiegelschrift und Marginalität in Rainer Maria Rilkes Die Aufzeichnungen des Malte Laurids Brigge. Tübingen: Francke, 2005. 
LUKÁCS, Georg. A teoria do romance. Tradução de José Marcos Mariani de Macedo. São Paulo: Duas Cidades; 34, 2003.

MACLEOD, Jock. "Writing as Paradox in Rilke's Notebooks of Malte Laurids Brigge". In: Modern Fiction Studies, Vol. 38, No. 2. Baltimore: The John Hopkins University Press, 1992. P. 403-425.

MARTENS, Lorna. "Autobiographical Narrative and the Use of Metaphor: Rilke's Techniques in Die Aufzeichnungen des Malte Laurids Brigge". Studies in Twentieth Century Literature, Vo. 9, No. 2. Manhattan: New Prairie Press, 1985.

"Reliable Narration: Rainer Maria Rilke's Die Aufzeichnungen des Malte Laurids Brigge”. In: The Diary Novel. New York: Cambridge University Press, 1985.

MARTINS, Renata de Freitas. A experiência do estranho no romance Die Aufzeichnungen des Malte Laurids Brigge. Departamento de Letras Modernas, Universidade de São Paulo, São Paulo, 2011.

MASSON, Jean-Yves. "Structure narrative et fragmentation dans 'Les Cahiers de Malte Laurids Brigge"”. In: BESSIÈRE, Jean, PAGEAUX, Daniel-Henri (org.). Le Roman du Poète: Rilke, Joyce, Cendrars. Paris: H. Champion, 1995.

MAZZARI, Marcus. "Hoffmann e as primícias da arte de enxergar". In: HOFFMANN, E.T.A. A janela de esquina do meu primo. Tradução de Maria Aparecida Barbosa. São Paulo: Cosac Naify, 2010. P. 59-74.

Labirintos da aprendizagem: pacto fáustico, romance de formação e outros temas de literatura comparada. São Paulo: 34, 2010.

MERLEAU-PONTY, Maurice. "O olho e o espírito". In: O olho e o espírito. Tradução de Paulo Neves e Maria Ermantina Pereira. São Paulo: Cosac Naify, 2015. P. 15-56.

. "A dúvida de Cézanne". In: O olho e o espírito. Tradução de Paulo Neves e Maria Ermantina Pereira. São Paulo: Cosac Naify, 2015. P. 125-149.

MEYER, Herman. "Rilkes Cézanne-Erlebnis". In: idem. Zarte Empirie: Studien zur Literaturgeschichte. Stuttgart: J. B. Metzler, 1963.

NALEWSKI. Horst. “Kommentar”. In: RILKE, R. M. Schriften. Frankfurt am Main: Insel, 1996.

NAUMANN, Helmut. Malte-Studien: Untersuchungen zu Aufbau und Aussagegehalt der "Aufzeichnungen des Malte Laurids Brigge" von Rainer Maria Rilke. Rheinfelden: Schäuble, 1983.

NAUMANN, Helmut: Neue Malte-Studien: Untersuchungen zu Aufbau und Aussagegehalt der "Aufzeichnungen des Malte Laurids Brigge" von Rainer Maria Rilke. Rheinfelden: Schäuble, 1989. 
NIVELLE, Armand. "Rilke, Rodin und die Forschung". In: MOOG-GRÜNEWALD, Maria e RODIEK, Christoph (org.). Dialog der Künste: Intermediale Fallstudien zur Literatur des 19. und 20. Jahrhunderts. Frankfurt am Main: Peter Lang, 1989.

"Sens et structure des Cahiers de Malte Laurids Brigge". In: Revue d'esthétique, XII. Paris: Librairie philosophique J. Vrin, 1959.

NOVALIS. Pólen. Tradução de Rubens Rodrigues Torres Filho. São Paulo: Iluminuras, 2001.

PERSEUS DIGITAL LIBRARY. Tufts University, Medford. Disponível em: < http://www.perseus.tufts.edu/hopper/>. Acesso em: 29 mar. 2019.

POE, Edgar Allan. "The man of the crowd". In: Tales of Mystery and Imagination. London: CRW, 2003. P. 415-426.

READ, Herbert. Modern Sculpture: A Concise History. New York: Thames and Hudson, 1996.

REYNOLDS, Nicholas (org.). Sense and creative labor in Rainer Maria Rilke's prose works. Dissertação. Department of German and Scandinavian, Graduate School of the University of Oregon, Eugene, 2014.

RICHTER, Thomas. “diese amorphe Sprache': Versuch einer Systematisierung der Streichungen in Rilkes Entwurfshandschrift $\mathrm{zu}$ den Aufzeichnungen des Malte Laurids Brigge". In: GISI, Lucas Marco (org.). Schreiben und Streichen. Zu einem Moment produktiver Negativität. Göttingen: Wallstein, 2011.

"Textgenetische Edition der Entwurfshandschrift zu Rilkes Aufzeichnungen des Malte Laurids Brigge. Ein Werkstattbericht". In: Passim. Bulletin des Schweizerischen Literaturarchivs, 6. Bern: Schweizerische Nationalbibliothek, 2010.

RILKE, Rainer Maria. "Auguste Rodin”. In: Schriften. Herausgegeben von Horst Nalewski. Frankfurt am Main: Insel, 1996. P. 401-513.

. Auguste Rodin. Tradução de Marion Fleisher. São Paulo: Nova Alexandria, 2003.

Briefe. Erster Band, 1897 bis 1914. Wiesbaden: Insel, 1950.

Briefe aus den Jahren 1902 bis 1906. Leipzig: Insel, 1929.

Briefe über Cézanne. Herausgegeben von Clara Rilke. Wiesbaden: Insel, 1952.

"Briefe über Cézanne". In: Schriften. Herausgegeben von Horst Nalewski. Frankfurt am Main: Insel, 1996. P. 594-636.

As anotações de Malte Laurids Brigge. Prefácio e tradução de Maria Teresa Dias Furtado. Lisboa: Relógio D’Água, 2003. 
. Os cadernos de Malte Laurids Brigge. Prefácio e tradução de Paulo Quintela. Coimbra: Instituto Alemão da Universidade de Coimbra, 1955.

. Os cadernos de Malte Laurids Brigge. Tradução de Lya Luft. Rio de Janeiro: Nova Fronteira, 1979.

. Os cadernos de Malte Laurids Brigge. Tradução de Renato Zwick. Porto Alegre: L\&PM, 2009.

Cartas sobre Cézanne. Prefácio e tradução de Pedro Süssekind. Rio de Janeiro: 7 Letras, 2006.

. Das Florenzer Tagebuch. Frankfurt am Main: Insel, 1982.

Das Stundenbuch. Köln: Anaconda, 2007.

Die Aufzeichnungen des Malte Laurids Brigge. Frankfurt am Main: Insel, 1982.

O livro de horas. Tradução de Geir Campos. Rio de Janeiro: Civilização Brasileira, 1993.

A melodia das coisas. Contos, ensaios, cartas. Organização, tradução e apresentação de Claudia Cavalcanti. São Paulo: Estação Liberdade, 2011.

. "Moderne Lyrik". In: Schriften. Herausgegeben von Horst Nalewski. Frankfurt am Main: Insel, 1996. P. 61-86.

Neue Gedichte und Der Neuen Gedichte anderer Teil. Frankfurt am Main: Insel, 1975.

. Poemas. Organização, tradução e introdução de José Paulo Paes. São Paulo: Cia. das Letras, 2012.

. Poemas e Cartas a um jovem poeta. Traduções e prefácios de Geir Campos e Fernando Jorge. Rio de Janeiro: Estrêla de Ouro, 1967.

Rodin. Tradução de Daniela Caldas. Rio de Janeiro: Relume Dumará, 1995.

"Über Kunst". In: Schriften. Herausgegeben von Horst Nalewski. Frankfurt am Main: Insel, 1996. P. 114-120.

. "Von der Landschaft". In: Schriften. Herausgegeben von Horst Nalewski. Frankfurt am Main: Insel, 1996. P. 208-213.

"Worpswede". In: Schriften. Herausgegeben von Horst Nalewski. Frankfurt am Main: Insel, 1996. P. 305-400.

O diário de Florença. Tradução de Marion Fleisher. São Paulo: Nova Alexandria, 2002. 
RIOS, Rita. "Auguste Rodin - 'Crítica' como arte. Reflexos da experiência de Rilke com a obra de Rodin”. In: Cadernos de Letras, No. 25. Rio de Janeiro: UFRJ, 2009.

RODIN, Auguste. A Arte. Conversas com Paul Gsell. Tradução de Ana Olga de Barros Barreto. Rio de Janeiro: Nova Fronteira, 1990.

L’Art. Entretiens réunis par Paul Gsell. Paris: Bernard Grasset, 1911.

RYAN, Judith. “'Hypothetisches Erzählen': Zur Funktion von Phantasie und Einbildung in Rilkes 'Malte Laurids Brigge'”. In: ENGELHARDT, Hartmut (org.). Materialien zu Rainer Maria Rilke "Die Aufzeichnungen des Malte Laurids Brigge". Frankfurt am Main: Suhrkamp, 1974.

Rilke, Modernism and Poetic Tradition. Cambridge: Cambridge University Press, 2004.

SCHLEGEL, Friedrich. Conversa sobre a poesia e outros fragmentos. Tradução de VictorPierre Stirnmann. São Paulo: Iluminuras, 1994.

O dialeto dos fragmentos. Tradução de Marcio Suzuki. São Paulo: Iluminuras, 1997.

SCHNEDITZ, Wolfgang. Rilke und die bildende Kunst: Versuch einer Deutung. Graz: J. A. Kienrich, 1947.

SCHOOLFIELD, George C. "Die Aufzeichnungen des Malte Laurids Brigge". In: METZGER, Erika A. e METZGER Michael M. (org.). A Companion to the Works of Rilke. Columbia: Camden House, 2001.

SIMMEL, Georg. “As grandes cidades e a vida do espírito”. Tradução de Leopoldo Waizbort. In: Revista Mana, No. 11. Rio de Janeiro: Museu Nacional/UFRJ, 2005. P. 577-591.

SMALL, William. Rilke: Kommentar zu den Aufzeichnungen des Malte Laurids Brigge. Chapel Hill: University of Nort Carolina Press, 1983.

STAHL, August. “Kommentar”. In: RILKE, R. M. Prosa und Dramen. Frankfurt am Main: Insel, 1996.

STORCK, Joachim W. "Leben und Persönlichkeit”. In: ENGEL, Manfred (org.). Rilke Handbuch. Stuttgart: J. B. Metzler: 2013.

STRATHAUSEN, Carsten. "Rilke's Stereoscopic Vision". In: The Look of Things. Poetry and Vision around 1900. Chapel Hill; London: The University of North Carolina Press, 2003. P. 190-236.

SUZUKI, Márcio. "A gênese do fragmento". In: SCHLEGEL, F. O dialeto dos fragmentos. São Paulo: Iluminuras, 1997. 
TOBIAS, Rochelle. "Rilke's Landscape of the Heart: On The Notebooks of Malte Laurids Brigge". In: Modernism/modernity, Vol. 20, No. 4. Baltimore: The John Hopkins University Press, 2013. P. 667-684.

TODOROV, Tzvetan. A beleza salvará o mundo. Wilde, Rilke e Tsvetaeva: os aventureiros do absoluto. Tradução de Caio Meira. Rio de Janeiro: DIFEL, 2011.

TUCKER, William. The Language of Sculpture. London: Thames and Hudson, 1977.

VÖLTZ, Heide. "Realität" und "Fiktion" aus systemtheoretischer Perspektive in Rainer Maria Rilkes Die Aufzeichnungen des Malte Laurids Brigge und Duineser Elegien. Stuttgart: Hans-Dieter Heins, 2003.

WAHRIG Deutsches Wörterbuch. München: Brockhaus, 2011.

ZIOLKOWSKI, Theodore. Dimensions of the Modern Novel. Princeton: Princeton University Press, 1969. 